\title{
Patients of the colonial state
}

Citation for published version (APA):

Zondervan, S. (2016). Patients of the colonial state: the rise of a hospital system in the Netherlands Indies 1890-1940. [Doctoral Thesis, Maastricht University]. Maastricht University.

https://doi.org/10.26481/dis.20160929sz

Document status and date:

Published: 01/01/2016

DOI:

$10.26481 /$ dis.20160929sz

Document Version:

Publisher's PDF, also known as Version of record

\section{Please check the document version of this publication:}

- A submitted manuscript is the version of the article upon submission and before peer-review. There can be important differences between the submitted version and the official published version of record.

People interested in the research are advised to contact the author for the final version of the publication, or visit the DOI to the publisher's website.

- The final author version and the galley proof are versions of the publication after peer review.

- The final published version features the final layout of the paper including the volume, issue and page numbers.

Link to publication

\footnotetext{
General rights rights.

- You may freely distribute the URL identifying the publication in the public portal. please follow below link for the End User Agreement:

www.umlib.nl/taverne-license

Take down policy

If you believe that this document breaches copyright please contact us at:

repository@maastrichtuniversity.nl

providing details and we will investigate your claim.
}

Copyright and moral rights for the publications made accessible in the public portal are retained by the authors and/or other copyright owners and it is a condition of accessing publications that users recognise and abide by the legal requirements associated with these

- Users may download and print one copy of any publication from the public portal for the purpose of private study or research.

- You may not further distribute the material or use it for any profit-making activity or commercial gain

If the publication is distributed under the terms of Article $25 \mathrm{fa}$ of the Dutch Copyright Act, indicated by the "Taverne" license above, 


\section{PATIENTS OF THE COLONIAL STATE}

THE RISE OF A HOSPITAL SYSTEM IN THE NETHERLANDS INDIES 1890-1940 
PATIENTS OF THE COLONIAL STATE

The rise of a hospital system in the Netherlands Indies,1890-1940

(C) 2016 Sjoerd Zondervan

\section{ISBN/EAN 9789462954632}

Design cover: Barbra Epping

Lay out: Wendy Schoneveld || www.wenz iD.nl

Printing: Uitgeverij BoxPress 


\section{PATIENTS OF THE COLONIAL STATE}

THE RISE OF A HOSPITAL SYSTEM IN THE NETHERLANDS INDIES $1890-1940$

\section{PROEFSCHRIFT}

ter verkrijging van de graad van doctor aan de Universiteit Maastricht op gezag van de Rector Magnificus, Prof. dr. Rianne M. Letschert volgens het besluit van het College van Decanen in het openbaar te verdedigen op donderdag 29 september 2016 om 14:00 uur

door 


\section{Promotores}

Prof. dr. E.S. Houwaart

Prof. dr. P. Boomgaard (Universiteit van Amsterdam)

\section{Beoordelingscommisie}

Prof. dr. F. G. Huisman, UM/UU (voorzitter)

Dr. E.Q. Hesselink, Leiden

Dr. A. Krumeich

Prof. dr. J.A.M. Maarse

Prof. dr. H. Schulte Nordholt, Universiteit Leiden 


\section{CONTENTS}

ACKNOWLEDGMENTS

$\begin{array}{ll}\text { PREFACE } & 7\end{array}$

$\begin{array}{lll}\text { CHAPTER } 1 \text { INTRODUCTION } & 9\end{array}$

CHAPTER 2 HEALTH CARE AND HOSPITALS IN VOC TIME 21

CHAPTER 3 HEALTH CARE AND HOSPITALS IN THE 19TH CENTURY 51

CHAPTER 4 A PERIOD OF TURMOIL $(1890-1910)$

CHAPTER 5 TIMES OF EXPANSION, TIMES OF AWAKENING (1910-1930) 135

CHAPTER 6 A PERIOD OF DECENTRALIZATION (1930-1942) 189

CHAPTER 7 REFLECTIONS ON THE RISE OF A HOSPITAL SYSTEM 235

$\begin{array}{lll}\text { APPENDICES APPENDIX } 1-7 & 256\end{array}$

SOURCES AND LITERATURE 266

BIBLIOGRAPHY 268

CURRICULUM VITAE $\quad 285$

FIGURES AND TABLES $\quad 286$

GLOSSARY 288

ABBREVIATIONS $\quad 290$

INDEX OF SUBJECTS 


\section{ACKNOWLEDGMENTS}

I owe the completion of this thesis to the support and guidance of many people, whom I wish hereby to thank. First, I want to thank my two supervisors, Eddy Houwaart and Peter Boomgaard, who had a lot of patience with the lack of focus from which I suffered at the beginning of my efforts. They inspired me with many ideas and alternatives and were very strict on language. My brother in law, Sipke van der Velde, corrected my use of language and patiently and in a meticulous way revised my texts. Joe Sergeant, my friend and coach during my endeavours in the field of science, did the same and managed to improve my texts in such a way that I need not feel afraid that native speaking scholars fail to understand my work.

Some years ago, the Leiden University decided to liquidate the Department of Medical History. By mutual agreement with Harm Beukers, Professor of Medical history at Leiden at that time, I decided to move my research to de Vrije Universiteit at Amsterdam. However, a similar fate befell the same department at de Vrije Universiteit at Amsterdam during the academic year 2013. Now in the last year of my research, I had to move again, this time to Maastricht, where my supervisor Eddy Houwaart holds a chair.

Prior to starting this research project, I received a lot of inspiration from the national master course Medical History that Houwaart started in 2005. This initiative took place in close cooperation between the Vrije Universiteit and the Leiden University. This course continues to inspire medical and history students. Liesbeth Hesselink was one of my fellow students, who followed this course. She preceded me some years ago in defending a thesis on indigenous healers in colonial Netherlands Indies. I am indebted to her for her study, which gave me the confidence to continue my own research in the medical history of the Netherlands Indies.

I want to thank the KITLV at Leiden, the KIT at Amsterdam and the Nationaal Archief and

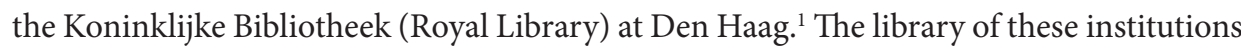
provided me with much source material. The annual courses that the KITLV organized in cooperation with the Vrije Universiteit on the subject of Indonesia inspired me with new energy and enthusiasm. ${ }^{2}$

1 KIT, Koninklijk Instituut voor de Tropen (Royal Tropical Institute) at Amsterdam.

2 KITLV, Koninklijk Instituut voor Taal-, Land en Volkenkunde (Royal Netherlands Institute of Southeast Asian and Caribbean Studies) at Leiden. 


\section{PREFACE}

My first contact with health care in a tropical setting took place in the Ivory Coast, a former French colony that obtained independence in 1962. I was employed by the Methodist Missionary Society at London and my assignment for the Ivory Coast was to administer a number of projects, among which a small hospital at Dabou. After my return to the Netherlands, I obtained employment in the Dutch health care. With this dual background, I occasionally received invitations to pay consultancy visits on health care in developing countries. In 2001 and 2003, the PUM (Netherlands Management Cooperation Project) invited me to look into organization and finances of a private hospital at Ujung Pandang (Makassar). ${ }^{3}$ On that occasion, I visited some hospitals in the northern part of Sulawesi, the Minahasa. In 2008, I visited a Muslim Hospital at Mojokerto (East Java), also on behalf of the PUM.

During my studies of history at the Vrije Universiteit at Amsterdam, I attended the master course Medical History given by Eddy Houwaart and became interested in the medical history of the Netherlands Indies, which resulted in a working paper on Hospitals in the Netherlands Indies. ${ }^{4}$ My master thesis was on Dutch hospitals and NI hospitals in the $19^{\text {th }}$ century, a comparative study. ${ }^{5}$ These working papers were the prelude to this thesis. My Indonesian experience, especially, strengthened my motivation to study the history of the hospitals of the archipelago. I chose the period of the last fifty years of colonial rule, since during that time the modern hospital arose.

3 PUM, Netherlands Management Consultants Project, a subsidiary of the Netherlands Employer's Association in cooperation with the Ministry of Foreign Affairs.

4 S. Zondervan, De ziekenhuizen van Nederlands Oost-Indië in de negentiende eeuw. (Paper Master Course Medical History of the VU/Vumc, Amsterdam 2005).

5 S. Zondervan, De ziekenhuizen in Nederland en Indonesië in de 19e eeuw, een vergelijking van de ontwikkelingen. (Master paper History Vrije Universiteit, Amsterdam 2006). 



\section{CHAPTER 1}

\section{INTRODUCTION}


The introduction of Western health care in Indonesia took place about four centuries ago, when the Vereenigde Oostindische Compagnie (VOC) founded a hospital "voornamelijk voor schepelingen", the sailors' hospital. ${ }^{1}$ Since then hospitals continued their presence in South-East Asia for different target groups, starting with care and treatment for the military and for the VOC personnel, mainly Europeans. In 1942, all racial communities on Java and the Outer Provinces benefited from these services, including: Javanese, Chinese, Soendanese and Moluccans. And so did the social classes of planters, coolies, civil servants, peasants and others.

In this book, an account is given of nearly all the hospitals that succeeded the sailors' hospital during Dutch rule. At the beginning of the 1940s, more than 600 hospitals provided health care in the archipelago, a development paved with successes and failures. The actors who started initiatives often encountered major problems. These varied from counteraction of local rulers or priests, lack of finances, problems of staffing and most frustrating: the disinclination of the native population to make use of their services. It took quite a while, before the ordinary people of the Netherlands Indies voluntarily applied for admission to hospital services. They had depended upon their traditional healers and felt no inclination to change and undergo treatment by Western practitioners. This reluctance may also have been due to bad experiences with Western medicine. From the start of the Dutch presence in the archipelago, the population witnessed a high mortality among Europeans, which could be noticed by crowded churchyards, often close to hospital grounds. No doubt, this did not encourage use of Western health care. But whatever the other reasons may have been, it took 300 years before the population more or less voluntarily submitted to the health services of Western doctors and nurses and took recourse to Western hospitals. This same reluctance to use Western medicine and its institutions, could be found in the countryside and in the cities of the European continent. Not only rural communities, but also city-dwellers continued to rely on traditional medicine at the turn of the $19^{\text {th }}$ century. ${ }^{2}$

This book describes the development of the modern type of hospitals in the period 18901942. This time span has not been chosen arbitrarily. The starting point of this research is centred around the birth of the modern hospital, which began towards the end of the 19th century in Europe and the United States. The year 1942 coincides with the Japanese invasion, which actually led to the end of the colonial era. ${ }^{3}$ The hospital organization gradually developed into a working place in which well-educated employees applied modern scientific views and medical technology and offered treatment. In the $20^{\text {th }}$ century,

1 VOC: Verenigde Oost-Indische Compagnie (Dutch East India Company).

2 J.A. Verdoorn, Het Gezondheidswezen te Amsterdam in de $19^{c}$ eeuw (Nijmegen 1981) 338-362. Transl.: The Health care system in Amsterdam.

3 For some European countries (France, Great Britain) it took place at an earlier stage. 
hospital treatment extended to all classes of patients. This development did not only take place in the Western world. Hospitals in the colonial environment very much resembled the Western metropolitan examples and adopted the same changes, sometimes after a delay.

\section{HISTORIOGRAPHY OF HEALTH CARE IN THE NETHERLANDS INDIES}

In the 1930s the medical historian D. Schoute published two important works: one on the history of health care in the $19^{\text {th }}$ century and one on the same subject in the VOC-era. In the first publication, the author discussed the development of military health care and military hospitals besides private hospitals. ${ }^{4}$ In the other study he established that health care and hospitals during the two centuries of VOC rule coincided. ${ }^{5}$

In general, literature that reviewed colonial history, such as that of Colenbrander, treated health care casually or even did not mention it at all. ${ }^{6}$ De Jong paid considerable attention to the developments in the field of education, but neglected the sector of health care. ${ }^{7}$ The same may be said about volume 11 of the Algemene Geschiedenis der Nederlanden, in which the Netherlands Indies is discussed. ${ }^{8}$ Volume 14 of the same series ignores health care or hospitals too. ${ }^{9}$

Recently, the actual historiography of health care in the Netherlands Indies in the $20^{\text {th }}$ century was discussed by Liesbeth Hesselink. In summarizing her findings on medical historiography of the Netherlands Indies, this author mentioned a few dissertations on the subjects of midwifery (J.A. Verdoorn) and on Willem Bosch, the founder of the dokter djawa school (A.H. Borgers). ${ }^{10}$ She mentioned also the department of medical history at Nijmegen University (KUN), which took interest in the medical historiography of the Indonesian archipelago and organized a series of lectures in 1989.

In the 1990s, the historian Peter Boomgaard of the Leiden Royal Netherlands Institute of Southeast Asian and Caribbean Studies (KITLV) published on health care issues in the Netherlands Indies. Concerning the period prior to independence, Boomgaard considered that the historiography of health care was a neglected field of research. ${ }^{11}$ The number of

4 D.Schoute, "De geneeskunde in Nederlandsch-Indië gedurende de negentiende eeuw." GTNI 74 (1934) and 75 (1935). Transl.: Medicine in the NI during the 19th century.

5 D. Schoute, De Geneeskunde in den dienst der Oost-Indische Compagnie in Nederlandsch-Indië (Amsterdam 1929). Transl.: Medicine of the Dutch East India Company.

6 H.T. Colenbrander, Koloniale Geschiedenis,3e Deel, Nederland, de Oost sinds 1816 ('s Gravenhage 1926). Transl.: Colonial History, The Netherlands. The East since 1816.

7 J.J.P. de Jong, De waaier van het fortuin, de Nederlanders in Azië en de Indonesische archipel 1595-1950 (Den Haag 2000). Transl. The wheel of fortune, the Dutch in Asia and the Indonesian archipelago.

8 C. Fasseur, "De Nederlandse koloniën 1795-1914." in: Algemene Geschiedenis der Nederlanden 11 (Bussum 1983) 347-381. Transl.: The Dutch colonies 1795-914, in General History of the Netherlands.

9 S.L. van der Wal, "Nederland en Nederlandsch-Indië 1914-1942", in: Algemene Geschiedenis der Nederlanden 14 (Bussum 1979) $379-400$.

10 Liesbeth Hesselink, Healers on the colonial market. Native doctors and midwives in the Dutch East Indies (Leiden 2011) 6-8.

11 Peter Boomgaard, "The development of colonial health care in Java; an exploratory introduction", BKI 149 (1993) 77-93. 
books and articles published recently was small. In contrast, this subject received more attention in other countries with a colonial past. Fortunately, there is no lack of sources concerning the medical history of the Netherlands Indies.

\section{HISTORIOGRAPHY OF HOSPITALS}

Specific research on the history of hospitals in the Netherlands Indies is very limited. In the medical historical literature of the colonial era, little attention was given to hospitals. Schoute claimed that during the last decades of the 19th century, not a single article was published on this subject and the same could be said of the first 25 years of the 20th century. Schoute characterized this period as the epoch of "renaissance" of hospitals in the Netherlands Indies. The primary place in the health system that military hospitals had occupied during the 19th century, changed and civil hospitals gradually developed into modern hospital organizations. This process started with the founding of a growing number of private hospitals and by the reorganization of the Burgerlijke Geneeskundige Dienst (Civil Medical Service) and the Militaire Geneeskundige Dienst (Military Medical Service). ${ }^{12}$ The former head of the Provincial Health Service of West Java, P. Peverelli published a survey on public health, but in his study, which covered a period until 1936, only four pages were dedicated to hospital development. Most attention was given to the role of the Government in providing health care for the population of the Netherlands Indies. ${ }^{13}$

The objective of this thesis and research is to describe the characteristics of the emerging hospital system during the period 1890 - 1942. In other words: to write the unwritten chapter of that period.

With respect to the specific historiography of hospitals Houwaart distinguishes three aspects. Historiography as a tool of modernization that pursued a practical aim: writers of this type of historiography describe the history of hospitals in order to emphasize the need for reforms. ${ }^{14}$ According to the author, this represents the oldest form of historiography. It dates from the 18th century and continues well into the 20th century. Examples of this kind of historiography we meet in Indonesia in the writings concerning the necessity to rebuild the obsolete and malfunctioning old Stadsverband (City Dressing Station) and the necessary reform of psychiatric institutions on Java. ${ }^{15}$ Houwaart demonstrates this research tradition

12 The Dutch abbreviations were BGD and MGD. Later on, more explanations about private hospitals and their place in the hospital system, will be furnished.

13 P. Peverelli, De zorg voor de volksgezondheid in Nederlandsch-Indië ('s Gravenhage, s.a.). Transl.: The care of public health in NI.

14 E.S. Houwaart, "Het ziekenhuis. De ontwikkeling van het ziekenhuis in de moderne tijd”, in: M.S.C. Bakker ed., Techniek als cultuurverschijnsel (Heerlen 1996) 238-355. Transl.: The hospital. The development of the hospital in modern time. Technology as cultural phenomenon.

15 According to Schoute many inspection reports on the Stadsverbanden at Batavia, Soerabaja and Semarang denounced the hygienic and building conditions of these hospitals and spoke out for reorganization and reconstruction of the buildings. 
with a few examples of "paradigmatic hospitals", individual hospitals with technical and social innovations that inspired other hospitals to take over these innovations in their hospital plans (Coolsingelziekenhuis Rotterdam, St. Thomas' Hospital London, a.o.). ${ }^{16}$ A second research tradition focuses on the regulation and ranking of different types of hospitals. The German school within this tradition points to principles of design and architecture of hospitals. In discussing the most desirable hospital architecture in the tropics, various authors advocate the pavilion style: they recommend that all new hospitals in Indonesia be built in this style instead of the prevailing Corridor system. These authors refer to the German school and some of them designed a detailed building program for hospitals in the tropics. ${ }^{17}$

The third form of historiography of hospitals draws attention to the social context in which a hospital functioned. The medical historian, H. Sigerist, achieved a fundamental renewal of historiography of hospitals in his "social history of medicine" approach. ${ }^{18}$ This approach tries to describe the development of the hospital in the context of political, social and economic factors. This author arranged the history of hospitals in three stages: medieval plague hospitals, pest houses and lazarettos to the almshouses for the deserving poor or diseased persons of the $17^{\text {th }}$ century to the scientific institute that aims at curing of diseases and that developed from about 1850. According to Sigerist, social processes could explain the first two developments, but the development of the modern hospital was entirely due to the progress in medicine and surgery. Other writers saw the rise of the modern hospital in an urban context of social changes, for example, Morris J. Vogel, speaks of the invention of the modern hospital'. This author described the development of the Boston general hospitals between 1870 and 1920 . He emphasized that above all social and economic factors contributed to transform charity hospitals into modern scientific institutions. These modern hospitals attracted not only the poor, but substantial numbers of middle class patients ${ }^{19}$. Charles E. Rosenberg described the rise of America's hospital system, using the Baltimore general hospital as an example. By 1900, the hospital had not only spread widely in the United States, but it had become a potential recourse for a much larger proportion of Americans. 'The care of strangers' involved the prosperous and respectable as well as the indigent patients. These patients were now treated in hospitals by new disease concepts, therapeutics, diagnostic tests and surgical procedures. These new patient categories and tools affirmed the hospital's new role in medical care ${ }^{20}$.

16 Houwaart, "De ontwikkeling van het ziekenhuis in de moderne tijd", 245-252.

17 In the Bijblad bij het Staatsblad (Annex to the Statutebook) no. 5852 of 31st March 1903 a detailed model for a 120 beds Inlandsche ziekeninrichting (Indigenous hospital) is designed.

18 Elsewhere (David Landey) Sigerist is quoted as one of the pioneers of medical anthropology.

19 M.J. Vogel, The invention of the modern hospital, Boston 1870-1930 (Chicago 1985).

20 Ch.E. Rosenberg, The care of strangers, the Rise of America's Hospital system (Baltimore 1995). 


\section{PRIMARY OBJECTIVE}

The primary objective of this study is to write the unwritten chapter in the historiography of hospitals in the Netherlands Indies. This requires research into the circumstances, activities, actors and results of the hospital system during the years of its development, from 1890 to 1942 . The following questions are linked to this objective:

- Who were the initiators of hospitals?

- What were their motives to establish hospitals?

- What kind of hospitals were established?

- How were these hospitals distributed in the different parts of the archipelago?

- Was there a model of hospital architecture and hospital organization the initiators could consult?

- Was there a plan or directive responsible for the developments?

- Did the market concept apply to hospital services?

The research will aim at finding an answer to these questions and will deliver a description of the emerging hospital system. With regard to the term hospital system, the next question is: what were its characteristics? May we speak of a system or was the result of the developments, a medley of different individual components without coherence?

At the end of the $19^{\text {th }}$ century, the health sector of the Netherlands Indies offered a picture, consisting of Western health facilities, such as a vaccination service, provisions to contain epidemics (quarantine), hospitals and a small number of European (mainly Dutch) physicians in the cities, alongside the doekoens (traditional healers) and Chinese doctors. The health culture of the indigenous population was focused on traditional health providers.

My hypothesis is that gradually medical pluralism developed in the NI. The local population had access to both traditional and Western health care. Since choice of service was no longer limited to local doekoens, but to a growing number of dokters djawa and Western doctors, the question is what made the Indonesian patient decide to seek treatment in hospitals? As a matter of course the question arises: where there attempts made to integrate parts of traditional care with Western health care?

\section{CONCEPTUAL FRAMEWORK}

There are various ways to look at hospital development. My approach will be a combined one: I will combine aspects of hospital economics and medical history.

Hospital economics studies the hospital as a business organization that needs economic (scarce) resources (labour and capital) to produce its services. For business organizations, it is essential that choices are made between alternative ways to organize services. Actually, there are two approaches to these alternatives:

- Disposing of a fixed budget, the choice is between a number of combinations of equipment and labour that do not exceed that budget. 
- Aiming at a certain outcome, the most efficient combination of labour and capital should be chosen.

Hospital economics is about making choices in applying means and in organizing the business process. There are internal and external aspects involved in the organizing process. In studying the internal organizational aspects, attention will be paid to the input of personnel and knowledge, to capital goods such as buildings and equipment and to the product: the services delivered. In studying external organizational aspects, one must consider hospitals from the point of view of their various characteristics (general against specialized, private against public, civil versus military). The concepts general and specialized describe the nature of hospitals in terms of groups of patients served and therapies used. The general hospital unites diverse medical specialties (for example, Surgery and Cardiology and Neurology, etc.) in one hospital organization and offers a diversified package of services. In contrast, the specialized hospital offers only one specialism (Obstetrics or Psychiatry or Ophthalmology, etc.) or concentrates its services on only one type of diseases (Leprosy or venereal diseases, etc.). The pair of concepts private and public refers to the ownership of hospitals. Private hospitals are initiated and/or run by private persons, private foundations, private associations or private companies. Public hospitals are initiated and operated by local, regional or central public agencies and their employees are public servants. These latter external organization features are subject to processes of integration and differentiation. This study will give attention to these processes.

In the context of a medical historical approach, actors, periods, circumstances, developments and results are important. This involves:

1. The hospital situation that existed before 1890 .

2. The hospital situation from 1890 to 1942; Who were the actors, where, when and under which circumstances did they act and what were the results in terms of hospital establishments? For both (1) and (2) the elements of research are: places of establishment, kind of hospitals, the type of clients, architecture, personnel and finance.

3. The division of the main period of research (1890 to 1942) into distinct periods (See periodicity of the object).

Within this conceptual framework, the driving force of the early development of hospitals in the Netherlands Indies suggests the following hypothesis: The founding and development of hospitals were essentially based on economic motives. The needs of patients were not leading in the establishment of hospitals. This means in economic terms that the suppliers of hospital services could not rely on the purchasing power of consumers who were in demand of their services. If this proves to be true, it would be premature to speak of a medical market for the Netherlands Indies. 


\section{CIVIL HOSPITALS IN COLONIAL TIMES IN THE NETHERLANDS INDIES}

This thesis focuses on the civil hospital in colonial times in the Netherlands Indies. As this phrase contains three elements: object, periodicity and geography, I will elaborate on each of these three elements.

\section{Description of the object}

How to define the object civil hospital?

First of all, the prefix civil is often used to contrast with public (e.g. civil law and public law). In the hospital situation of the Netherlands Indies, civil is used in contrast with military. During most of the $19^{\text {th }}$ century, health care was provided by two organizations: The Military Medical Service (MMS) and the Civil Medical Service (CMS). ${ }^{21}$ Of these two, the military played a dominant role and were in charge of the management of both services. This being so, it is impossible to ignore the existence of a few hundred military hospitals during most of the $19^{\text {th }}$ century. However, it is only in chapter 3 that we will dwell upon the existence and function of the military and the significance and functioning of the MMS. For the main period of research, this book concentrates on hospital care for civilians and we extend the meaning of civil hospitals to include private and public hospitals for civilians, but not public hospitals for military personnel. The private hospitals owe their existence to the activities of private parties, such as missionary societies, different types of companies or population groups. The public hospitals are initiated or managed by public agencies, such as the central government, municipalities, regional councils or provinces. To be precise: I talk about private and public hospitals for civilians, shortened to civil hospitals.

The second part of the object civil hospital contains the word hospital. The phenomenon hospital will be defined in contrast to almshouse. ${ }^{22}$ The character of the almshouse was charity. The almshouses provided the ill and poor people with care, bed and breakfast, almost without elements of cure. ${ }^{23}$ The hospital is an institution that is professional rather than charitable. ${ }^{24}$ It is an institution established to cure the ill and the injured. Both types of health care institutions were found in the Western world, but the modern hospital was only fully developed in some parts of Europe, including the Netherlands, not before the second half of the $19^{\text {th }}$ century. Both institutions, the old almshouse type as well as the modern variant had been absent in the Indonesian archipelago.

21 MGD: Militaire Geneeskundige Dienst (Military Medical Service); BGD: Burgerlijke Geneeskundige Dienst (Civil Medical Service).

22 Roy Porter, The greatest benefit to mankind, a medical history of humanity from antiquity to the present (London 1999) 236241.

23 Rosenberg, The care of strangers, $322-327$.

24 Iris Bruijn, Ships' Surgeons of the Dutch East India Company, Commerce and the Progress of Medicine in the Eighteenth Century (Leiden 2004) 97. 
One can easily imagine that the implantation of this modern Western phenomenon in the traditional health culture of Indonesia provided some problems. Most prominent was the refusal of the Indonesian patient to make use of its services. Therefore, an important question of this thesis is, why did many parties, including the NI government, nevertheless decide to establish these unwanted hospitals from 1890 onward?

\section{Periodicity of the object}

This research project focuses on the 50 years before independence. It is the time span 1890 - 1942. The choice for this period may be substantiated as follows: the period was marked by a start-up of many newcomers in the field of hospital care for civilians. From the 1890s, plantation companies, deaconess associations and missionary organisations took initiatives to establish hospitals. Besides the NI Government joined in stimulating hospital care for civilians. In the period before, the same Government repeatedly stated that it had no concern for civilian health care. All during the $19^{\text {th }}$ century this policy was maintained. The $19^{\text {th }}$ century was marked by the dominance of military in health care and by a dilapidation of civil hospitals. From the 1890s, this negligence of civil health care belonged to the past and what was called a "renaissance" of civil hospitals took place. This coincided with the rise of modern hospitals in the Netherlands and elsewhere in the Western hemisphere.

The period is divided into 3 distinct sub-periods:

1. The first period (1890-1910) is characterized as a period of turmoil and transition during which the primacy of the military medicine is gradually taken over by civilian medicine. This first period starts in the last decade of the 19th century and extends to 1910, when the formal start of the independent Civil Medical Service takes place. Chapter 4 will explain what this transition meant for civilian health care and hospitals.

2. The second period, covering the years 1910-1930, is one of rapid expansion. A drastic change of political views precedes this expansion. Ethical views become leading and the slogans education, emigration, irrigation and decentralization become key political ones. This ethical policy takes care of prosperity, education and health care for the indigenous people. The NI Government invests strongly in education and health care. Chapter 5 will explain how these political and financial efforts influenced the development of private and public hospitals.

3. The third period (1930-1942) shows stagnation. Influenced by the worldwide depression, budgets are cut. The central Government retreats and the decentralization process accelerates. Chapter 6 will explain how these developments influenced the private and public hospitals. 
The influence of contemporary political history on hospital development in these three periods will be discussed by noting political impulses and indicating their influence on establishment, reduction or expansion of hospitals. The same exercise will take place regarding socio-economic developments and their influence on hospitals. Questions and conclusions are formulated for each period and region.

\section{Geography of the object}

Civil hospitals existed on the island of Java and especially in the main cities of Java during VOC time as well as during the 19th century. During the $19^{\text {th }}$ century, a few indigenous hospitals could be found in the countryside and there were some Chinese hospitals in the main cities. The distribution of private and public hospitals over Java and the so-called Outer Provinces will be studied, in particular, in the course of the three periods mentioned previously.

\section{DATABASE}

A survey is made of all hospitals that existed or were founded in the period of research. From this survey, tables and summaries are established for each period, region and type of hospital. Analysis of this material has produced findings that have been assembled and discussed in each period. It proved to be impossible to produce the usual quantitative analyses of hospital economics. Ratio figures such as occupancy rates, bed turnovers, average length of stay could be established in individual cases, but not overall for each period, type of hospital or region. An attempt will be made to establish the comparative accessibility and availability of hospital services in the final period (1930-1942) by comparing some important regions and by looking for benchmarks in similar colonial situations. The database that supports this research is available on line..$^{25}$ The interested reader may thus consult more detailed information on individual hospitals.

\section{ARRANGEMENT OF CHAPTERS}

This book is divided into two parts:

A long prelude in which the reader will witness the exciting history of the three centuries that precede the period 1890 to 1942 , the time span of this thesis. The prelude is about hospitals in VOC-times, hospitals during a short French and English episode and the military hospitals of the $19^{\text {th }}$ century (chapter 2 on the VOC era and chapter 3 describing the period 1795 to 1890). These chapters provide examples of the first approach of hospital historiography (historiography as tool of modernization). 
In contrast to this long period, successive chapters cover relatively short epochs. Chapter 4 describes the tumultuous period around the turn of the century (1890-1910). During this period, the political scenery is dominated by imperialist activities. The central government pursues wars of conquest in Atjeh, Bali, and Borneo and in other regions of the archipelago. At the same time, the colonial policy changes from purely selfish to aiming at more ethical goals and towards emancipation of the population. Chapter 5 deals with the years 1910-1930, in which the largest expansion of private hospitals takes place. It is during this period that the Civil Medical Service changes its name into Dienst der Volksgezondheid (Public Health Service) in order to propagate a wider mission than only curative health care, as delivered by hospitals. Chapter 6 describes the last period, the years after 1930 until World War Two. Chapter 7 provides a summary and formulates the conclusions of this research.

Special attention has been given to the drawing of comparisons with other colonial health systems and health care developments in mother countries. The development of hospitals in Great Britain, France, the United States and The Netherlands over the period $1870-1920$ will be discussed in Chapter 3, titled Metamorphosis of hospitals. Similarities and differences between the health policy and establishment of hospitals in French Indochina, British India, the Philippines and the Netherlands Indies will be found in Chapter 4( $\$$ The rise of civil hospitals), Chapter 5 ( $\$$ Medical research and tropical medicine and $₫$ Medical legislation on epidemics) and Chapter 6 ( $\$$ Hospital personnel and $₫$ Balance). Some comparative conclusions will be formulated in a separate paragraph of Chapter 7.

\section{CHOICE OF VOCABULARY}

In this book some compromises had to be made on the use of 3 languages, put together in one publication.

First of all, as the main choice is for use of the English language, typical Dutch expressions (functions, names, etc.) will be used the first time in Dutch with an English translation, whereas subsequently the English equivalent will be used. Example: "Buitenhospitaal" will be translated in "Outer City Hospital" and in the following episodes the latter expression will be used. All footnotes will be translated by the author, except for the ones concerning titles of publications that are repeated. These will be translated once only. Quotes in the main text that are translated by me, will be mentioned in a footnote.

As for the Indonesian expressions, the colonial way of writing will be used. Example: Buitenzorg and not Bogor. Batavia and not Jakarta. Most geographical places nowadays use "u"_instead of "oe" and "j"or "y" instead of "dj”. In this book I use Djokjakarta instead of Yogyakarta and Soerabaja instead of Surabaya.

Some Dutch (except the ones that are translated in the main text) and most Malay words and expressions will be put in Italic type and will be explained in the Glossary at the end of this book. 



\section{CHAPTER 2}

HEALTH CARE AND HOSPITALS IN VOC TIME 
At the beginning of the $17^{\text {th }}$ century Dutch merchants joined forces and equipped a fleet to conquer the Southeast Asian spice market. It took some time before their company, the Verenigde Oostindische Compagnie (VOC), managed to defeat Portuguese and British competitors and to make a treaty with local rulers. ${ }^{1}$ But from the 1650 s the Dutch commercial presence on Java and on the Moluccas seemed firmly established. In the wake of the merchants, came many countrymen and adventurers to settle in the East Indies. A European settlement grew in some of the towns of Java, especially in Batavia, the main seat of the Hoge Regering. ${ }^{2}$

In a period of 94 years of the $18^{\text {th }}$ century, 750 ships were built in the Dutch Republic. These ships transported in 2,950 outward voyages round 655,000 voyagers (crew and passengers) that served the VOC. This meant an average of 222 individuals per ship. By far the largest groups on board were seamen (60\%) and soldiers (30\%). The VOC-period covered almost two centuries (1602-1794) and came to an end due to economic mismanagement.

\section{THE VOC, DISEASES AND HEALTH CARE}

From the start in 1602, the VOC looked after the health of its employees by appointing chirurgijns (surgeons), by making available pharmaceutical products and by founding hospitals and other health facilities. ${ }^{4}$ In order to get a proper idea of the role and importance of hospital care in the East Indies during the $17^{\text {th }}$ and $18^{\text {th }}$ centuries, one has to take account of the conditions and circumstances in which employees such as seamen, soldiers and craftsmen arrived and were lodged. Often, these men arrived in Batavia after a long and troublesome voyage over sea, were sick and had no home to stay. They needed at least shelter to recover from their diseases. Such a shelter was provided for by the VOC in the form of hospital ships, infirmaries and town hospitals.

The professionals who took care of the patients were chirurgijns. They had medical knowledge acquired from the training at home, but also tried to make use of the local medical knowledge, partly from Portuguese origin, for a larger part from indigenous origin. It took some effort to find the effective substances and indigenous herbs and discover their healing qualities for treating tropical diseases. Therefore, cooperation with local practitioners was needed. An example of a fruitful cooperation was that of the chirurgijn Duraeus and the medical doctor Bontius who arrived in Batavia in the 1620s. Both were employees of

1 VOC: Verenigde Oost-Indische Compagnie: Dutch East-India Company was the first limited liability company of the Netherlands. The Head office of the VOC was subdivided into 5 so-called Kamers (Chambers), which represented 5 main offices in the towns of Amsterdam, Middelburg, Delft, Rotterdam and Hoorn/Enkhuizen. The highest authority of the VOC was called de Heeren XVII (Gentlemen XVII), 17 governors who were in charge of the company.

2 The Supreme Government was formed by the Governor-General and the Council of the Indies (Raad van Indië). This Hoge Regering was accountable to the Heeren XVII, the board of administrators of the VOC.

3 "Dutch-Asiatic shipping in the $17^{\text {th }}$ and $18^{\text {th }}$ centuries", in: J.R. Bruijn, F.S. Gaastra and I. Schöffer ed., Rijks Geschiedkundige Publicatiën ('s Gravenhage 1979) tables 27 and 30.

4 Chirurgijns (Surgeons) were barbers who in most cases were trained by their guilds to perform also simple surgery. 
the VOC and together they explored the flora of Java, executed experiments and consulted indigenous experts. Bontius published his findings in a book with the title De Medicina Indorum. ${ }^{5}$ Notwithstanding the eagerness of some of the VOC medical employees in finding remedies for the tropical diseases that they were confronted with, the result of their interventions is reported to be rather disappointing, especially to their employers in the Republic, de Heeren XVII.

In retrospect, the achievement of health care by chirurgijns and hospitals in the Netherlands Indies during the VOC period seems to have little or no effect in view of the increasing rate of mortality in hospitals at Batavia. Especially in the second half of the $18^{\text {th }}$ century and despite numerous measures taken, the death rate reached an extreme level of $36 \%$ for the then serving European population in Batavia. Compared to elsewhere in the Netherlands Indies and in settlements elsewhere in the world, the mortality in Batavia and the north coast of Java was by far the highest. By comparison, mortality figures in Sri Lanka were $40 \%$ and in Bengal $80 \%$, but in Cape of Good Hope the figure was also rather high: $170 \%$. In this period, the average mortality in the big European cities was $30 \%$. In Berlin (at that time) it was about $50 \%$ o (including stillbirths). ${ }^{6}$ Before 1750 and before the demographic transition, gross mortality figures varied between 30 and $50 \%$ in Western Europe. ${ }^{7}$ For decades, despatches were sent to and from Holland and Batavia concerning measures to be taken to fight the deadly fevers, the so-called febris intermittens or intermitteerende koorts.

The historian P.H. Van der Brug tried to analyze why all the research on the causes of the heavy death toll did not come near a finding that pointed to malaria, the cause that he identified. ${ }^{8}$ After 1733 , the mortality rate rose to double the number before and the author demonstrated that the expansion of the fish ponds near Batavia attracted Anopheles sundaicus mosquitoes that were responsible for the deadly falciparum malaria. Victims were mainly found among the new arrivals from Europe who were weakened by the harsh sea voyage and had no resistance at all against malaria. This situation remained unchanged during the rest of the eighteenth century.

The intermittent fevers were the most frequent cause of death and it was not the only disease Europeans incurred. On board the ships, many seamen and soldiers suffered from scurvy or unknown fevers and many died aboard or came ashore in a very poor condition. From 1695 onward the ships' surgeons were obliged to keep journals. Although some of these

5 J. Bontius, De Medicina Indorum (Leiden, 1642).

6 Arthur E. Imhof, "From the old mortality pattern to the new: Implications of a radical change from the sixteenth to the twentieth century." Bulletin of the History of Medicine 59 (1985) 1-29.

7 M. Duijvendak, P. Kooij, Sociale geschiedenis, theorie en thema's. Transl.: Social history, theory and themes (Assen 1992) 32.

8 P.H. Van der Brug, Malaria en Malaise, De VOC in Batavia in de achttiende eeuw (Amsterdam 1994) 98-136. Transl.: Malaria and Malaise, the VOC in Batavia in the 18th century. 
journals still exist, they do not supply morbidity or mortality statistics. ${ }^{9}$ Except for scurvy, wounds and fractures the ships' surgeon often did not know the cause, diagnosis and cure of many diseases observed. Many seamen died because of bad living conditions, lack of fresh air, lack of hygiene, lack of time to relax, and lack of fresh water. These conditions impaired the health of those who had become victim of some disease. On coming ashore, the patients were transported to hospitals, where often new diseases worsened their condition. The treatment of many diseases was a matter of trial and error. Sometimes patients recovered in spite of the "therapy". Schoute tells about Frikius, a German surgeon, who fell ill during his duties on Banda:

Probably he was suffering from beriberi. The surgeons subjected him to a cure in a sort of sweating-room; every day he was placed in a pit the inner walls of which were lined with benches; two fires were built in the pit and the latter covered up with a sail, through which only the heads of the patients protruded. With their heads above the sail, the patients' bodies were subjected to great heat while a vat containing water and herbs emitted a dense steam. At the end, the patients were carried away on a mattress in a condition that was worse than before. ${ }^{10}$

It seems obvious to compare the disease and mortality rates of the Europeans with the rates experienced by the indigenous population, living in the same unhealthy places. Unfortunately, there are no statistics concerning the mortality rates of the local population. Occasionally, there were reported natural disasters such as floods, earthquakes and periods of drought, famines and epidemics. Boomgaard mentions that, after the arrival of the Dutch, Java was hit by at least four severe epidemics in the $17^{\text {th }}$ century, namely in the periods $1624-1627,1644-1645$ and in $1674-1677 .{ }^{11}$ The author notes, that in the $18^{\text {th }}$ century two epidemics of more than local importance occurred during the periods 1745-1746 and 1757-1760. The latter killed at least 100,000 people in West Java and the Western parts of Central Java. The author estimates that this represents $10 \%-15 \%$ of the population in that area. Although the local population experienced high mortality from time to time (locally mortality could rise to $30 \%$ ), these figures, in general, did not approximate the ones experienced by Europeans, living in the towns of Bantam, Batavia or elsewhere on the north coast of Java in the $17^{\text {th }}$ and $18^{\text {th }}$ century.

9 Schoute, De Geneeskunde in den dienst der OIC, 53. In 1695 de Heren XVII obliged the ship surgeons by instruction to keep patient records.

10 D. Schoute, Occidental therapeutics in the Netherlands East Indies during three centuries of Netherlands settlement, 1600-1900 (Batavia 1937) 45.

11 Boomgaard, "The development of colonial health care", 77-93. 


\section{THE VOC AND ITS MEDICAL STAFF}

Each of the ships that left the ports of the Republic had one or two chirurgijns on board. Their task was to look after the health of the crew. On arrival in the East Indies, these men could get an assignment to look after the health of VOC servants in Batavia, in the Moluccas or elsewhere. Most of the chirurgijns had been members of guilds (Dutch or foreign) and had received some training before being admitted as a member of these organizations. In the home country, they received their regular income from hair-cutting and shaving and enjoyed an additional income from the patients they treated. However, the chirurgijns we refer to were employed as servants of the VOC. Their exclusive assignment was health care and they earned a regular monthly income by performing these duties. During the VOC epoch, the number of medical doctors with an academic degree, the doctors medicinae, was negligible in the East Indies. In practice, the surgeons did not only take care of surgical problems, but treated internal medical conditions as well, an activity strictly forbidden in their home countries.

Before entering the VOC-service the chirurgijns had to pass an additional examination. Many of them were of foreign origin and there was no guarantee about the quality of the master test they had passed at home. A medical team of two doctors and two surgeons, appointed by the VOC, conducted the surgery test. This team was also responsible for the medicine chests aboard the ships and was charged with the assessment of indemnification for persons who became disabled during VOC service. ${ }^{12}$ From 1618, the Company adopted a uniform settlement for her disabled employees in all its five Chambers. ${ }^{13}$ According to the Pay-registers of the voyages of VOC-ships one may distinguish various ranks of surgeons, varying from Opperchirurgijn (Chief surgeon) to 3rd chirurgijn and Onderchirurgijn (junior surgeon). Actually, the function of chirurgijn was divided into even more ranks. ${ }^{14}$ Von Römer mentions that from about 1730, the large number of Opperchirurgijns was reduced as most of them were not replaced when they died. The new function of Inlandsche chirurgijn (indigenous surgeon) was mentioned in a decree of Governor-General W. van Outhoorn (1691-1704). ${ }^{15}$

12 Schoute, Occidental therapeutics, 4-5.

13 The indemnity was 800 guilders for the loss of a right arm, 500 guilders for a left arm, for one leg $f 450$ and for the loss of both legs: $f$ 800. For a right hand $f 600$ was paid, for the loss of a left hand $f 400$ and for both hands $f 1000$.

14 Initially, the function of chirurgijn was divided into 7 ranks. The ranks of Onderchirurgijn and First and Second Onderchirurgijn were put together, because the last two appeared on the list for only a few years and with rather small numbers.

15 Decision of $24^{\text {th }}$ July 1699 : 'Inlandsche chirurgyns werden gemeenlyk na haer bequaemheyd tot 10 à 12 en uyterlyk 14 guldens ter maend onder een vyf jarig verband aengenomen, en daerna vervolgens tot 18 guldens en eyndelyk tot onder-chirurgyns met vier en twintig gulden ter maend g'advanceert, dog verder niet.' (Nederlands Plakaatboek 1602-1811, deel 17). Transl.: Indigenous surgeons may be appointed according to their skills for five years against the amounts mentioned and ultimately may be promoted to the rank of junior surgeon. 


\section{BATAVIA AND ITS POPULATION}

The Dutch merchant and Governor-General J.P. Coen founded Batavia in 1619. He built the new city on the ruins of the town of Jayakarta. Batavia became strong and rich during the $17^{\text {th }}$ century and was referred to as "Queen of the Orient". In 1730 the town had 20,000 inhabitants of different nationalities and in its immediate neighbourhood (called Ommelanden) lived another 100,000 people. A number of calamities were said to cause its decline in the course of the $18^{\text {th }}$ century: the slaughter of the Chinese in 1740 after a rebellion of Chinese plantation labourers, the ecological calamity caused by the deforestation of the hinterland and the creation of fishponds just outside the city walls. By 1790 most European inhabitants had fled Batavia because of the fevers and settled in a more elevated area called Weltevreden, currently, the centre of Jakarta. ${ }^{16}$

The Batavian population consisted for only a small part of Europeans, mostly employed by the VOC. ${ }^{17}$ In addition, and considered European, was a number of adult European vrijburghers, not employed by the VOC and some mestizos (people of mixed Asian and European parentage). Furthermore, there were mardijkers, descendants of slaves who were converted by the Portuguese and then set free. ${ }^{18}$ However, by far the largest population group was slaves. Another large group consisted of Chinese who, after the massacre of 1740, settled in kampong Cina outside the Diest Gate.

Hornstedt describes Batavia and the ethnic settlements in 1783. Each ethnic community was governed by its own head, a Captain, after 1774 a Major. There were 19 kampongs around the city, named after the nationality of their inhabitants: Moorish, Boeginese, Balinese, Ambonese, Boetonese, Malay and Mandarese. The Muslim kampongs had a total population of 68,000 according to Hornstedt. ${ }^{19}$ Niemeijer gives a figure of 31,854 for all the inhabitants of the town itself in 1679 and 49,688 for all the communities in the Ommelanden in $1699 .{ }^{20}$ In 1815, a total population figure of 140,000 is mentioned by Boomgaard for the Batavia Residency (town and Ommelanden). ${ }^{21}$

16 Leonard Blussé, “Coen en de stichting van Batavia," in: Anthony Reid ed. Geschiedenis van Indonesië, deel 2 Vroegmoderne geschiedenis (Abcoude 1998) 226. Transl. Coen and the foundation of Batavia.

17 The data on the ethnic distribution of the population of Batavia according to van der Brug, Malaria en Malaise, 33-36.

18 The Portuguese at first used the name mardicas, derived from the Sanskrit maharddhika which means rich and prosperous. In the old Java people meant by that a free man, freed from slavery. Nowadays the Bahasa Indonesia uses the word merdeka.

19 Ann Kumar, "A Swedish view of Batavia in 1783: Hornstedt's Letters." Archipel, Volume 37(1989).

20 Hendrik E. Niemeijer, Batavia, een koloniale samenleving in de 17 e eeuw (Amersfoort 2005) 400-401.

21 P. Boomgaard and A.J. Gooszen, Changing Economy in Indonesia, vol. 11 Population Trends 1795-1942 (Amsterdam 1991) $17-18$. 


\section{THE VOC AND ITS HOSPITALS}

During the $17^{\text {th }}$ century, the VOC gradually established commercial settlements in the East Indies. Together with the construction of fortifications and warehouses, the Company provided health facilities such as infirmaries, apothecaries or hospitals. The founding of Compagnie's sieckenhuysen (VOC hospitals) was closely connected to places of commercial interest or military significance. We may assume that the importance of these hospitals depended in large part on the density of the European population in the settlement.

Schoute observed that the development of hospitals mostly happened according to a uniform pattern. At first, a fortress was erected (in the Outer Islands at Ambon in 1605, Banda in 1609, Padang in 1664 and Makassar in 1666). ${ }^{22}$ Surgeons took care of patients who soon arrived afterwards. The patients were lodged in fortified places within the Castle or benteng. Afterwards, the first primitive hospitals appeared. They were built of materials such as atap and bamboo and were still found within the fortress. ${ }^{23}$ If safety improved, hospitals were built outside the fortress, but 'within the distance of a gunshot. ${ }^{24}$

The character of those hospitals is well described by Iris Bruijn: 'The hospitals in Asia were built to cure the ill and the injured. They were called Hospitals instead of Gasthuizen right from the start and were set up and financed by the Company, not by wealthy patrons, and certainly not by the church.'25

The first health care facilities were located in the Moluccas, the group of islands known for the cultivation of spices: cloves, nutmeg and mace. The VOC created settlements in the Moluccas and established a monopoly for growing and selling these popular and profitable products. They first had to evict the Portuguese and on the fortifications left by the Portuguese, they built their own fortresses, mostly called "Casteel" or "Fort". Because of its economic importance, the VOC established a strong military settlement in the Moluccas and the first three Governors-General, Both, Reynst and Reaal resided there. From about the 1650s, the Company erected brick hospitals on the islands of Amboina (1648), Ternate (1658) and Banda (about 1664). ${ }^{26}$ Dispensaries inside the fortresses existed in Makassar on the island of Celebes (Fort Rotterdam) and on Sumatra at Padang. After the founding of Batavia and its prosperous development, most hospital establishments were established on the island of Java at Batavia. Later hospitals became available in other places on Java: Bantam, Semarang and Soerabaja. All of these establishments served the Europeans and not the civilian population of these islands, though occasionally, indigenous patients were admitted. The authorities isolated patients suffering from leprosy by establishing leprosy

22 Vitruvius, Indonesia special, Volume 5 (2012)18: The Fortaleza Nossa Seinhora da Annunciada on Ambon was taken from the Portuguese and rebaptized into Kasteel Victoria. On Banda the fortresses Nassau and Belgica were built by the VOC in 1609. In 1667, the VOC conquered the existing fortress, which was called Fort Rotterdam.

23 Atap: thatched roof of palm leaves.

24 Schoute, De Geneeskunde in den dienst der OIC, 177-178.

25 Bruijn, Ships' Surgeons, 95-97.

26 Schoute, Occidental therapeutics, 40. 
institutions on the island of Purmerend in the neighbourhood of Batavia and on the island of Molanen near Ambon.

In the next section a brief survey of the hospitals of the VOC era will be presented by chronologically following the (approximate) dates of foundations. The following types of hospitals are distinguished in this survey:

- the general hospitals of Java

- the general hospitals on the Outer Islands ${ }^{27}$

- hospitals designated for specific population groups, such as the Chinese and Moorish sailors

- hospitals specialized to treat certain diseases, such as leprosy, or look after groups of patients, such as convalescents.

Before engaging on this $17^{\text {th }}$ and $18^{\text {th }}$ century journey into the hospital world, one should realize that the motives to found these hospitals had little to do with charity. In fact, the VOC agreed to invest money in hospitals for a supposed financial return. Actually, the governors of the Company hoped to diminish the losses of life due to risky sea-voyages and unhealthy living circumstances for their employees. The logic being that, if and when the founding of these hospitals proved successful, the number of voyages to organize for replacement of severely ill or dead employees could be reduced. The hospitals served the Company's needs and were 'professional', rather than charitable institutions (with the possible exception of some religious institutions in the larger settlements). Patients always paid for their admission to the hospital, with at least half, sometimes with their complete month's salary. ${ }^{28}$ In evaluating the role of hospitals instead of Gasthuizen, the question arises: what made the responsible authorities choose for this rather new approach in health care? Secondly, when they built hospitals, could they fall back on contemporary hospital designs?

As for the new approach, the cure or treatment aspect, it is obvious that the population of the VOC hospitals differed from the usual Gasthuis population at home: the latter had no means to pay for treatment and was quite satisfied with lodging and food only. VOC patients were employees who received regular reimbursement and hospital treatment costs were deducted from their income. Further, the VOC paid the chirurgijns and other hospital employees a regular monthly salary. In the homeland, doctors who were engaged to look after Gasthuis affairs visited these institutions only intermittently and considered these tasks as secondary occupations.

27 Usually, the administrative entities outside Java were called Buitenkantoren (Outer Offices) or Buiten Bezittingen (Outer Possessions) in VOC-time. Later on, names as Buiten Gewesten (Outer Regions) or Buitenprovincies (Outer Provinces) became common. The term Buitenkantoren was also used for the VOC settlements in other parts of Asia and Africa.

28 Bruijn, Ships' Surgeons, 97. 
With respect to the design of the VOC-hospitals: not much is known about the references used, but there is a rather well-described contemporary example on the island Ceylon (Sri Lanka), one of the other VOC trade stations in Asia (See figure 1). This hospital was built soon after the capitulation of the Portuguese in 1656 and its outline is thus described:

The design is a simple one, consisting of five wings, four of which are joined to form a square with a courtyard in the centre. The fifth wing constitutes the façade of the building and is situated in front of the square with a second courtyard intervening. The only part of the hospital with an upper floor is the front wing. However, this first floor is limited in extent, and appears like a compartment sitting atop the roof in the centre of the wing. A wooden staircase leads to this storey, which now has the appearance of a small hall. Its floor is made of wooden planks. As with other old Dutch buildings in Ceylon, the walls are over $50 \mathrm{~cm}$ thick and the teak beams are massive both in girth and length.... A long and wide open veranda runs along the length of each wing, and is another characteristic of old Dutch architecture in the tropics. ${ }^{29}$

In observing this early design, it may be noticed that elements of the so-called Hofbouw design are found back in the main structure: usually a number of 4 wings enclosing a courtyard. ${ }^{30}$ This style of hospital architecture became the dominant design from the $16^{\text {th }}$ century, after religious disputes had undermined the medieval health care, in which hospitals were run by religious orders and usually had the shape of a cross, being centred around a chapel. Houwaart describes this development of hospitals that took place in England, Germany, Austria and France. It was hardly known in the Republic, where the care of poor, old and sick persons was pursued as in the days before the Reformation: The Protestant Church and Protestant charity organizations became responsible and often continued the use of the old Gasthuizen. Only a few new and small hospitals were built, scattered over the country and a few large Pest- and Dolhuizen (hospitals for the insane and victims of the Plague). In 1630, a Pesthuis was opened in Amsterdam. It was surrounded by water and was one of the few examples of a hospital in Hofbouw style in The Netherlands. ${ }^{31}$

In building the Colombo hospital and the hospitals founded in the Netherlands Indies, it was clear that the reference the architects had, was the contemporary Hofbouw design, a design that in a later stage would be adjusted with elements typically adapted for the tropics, notably the added verandas and covered walkways.

29 C.G. Uragoda and K.D. Paranavitana, "The seventeenth-century Dutch hospital in Colombo", Medical History 29 (1985) 182-192.

30 Hof = Binnenplaats, Dutch for court yard.

31 Houwaart, De ontwikkeling van het ziekenhuis, 261-266. 


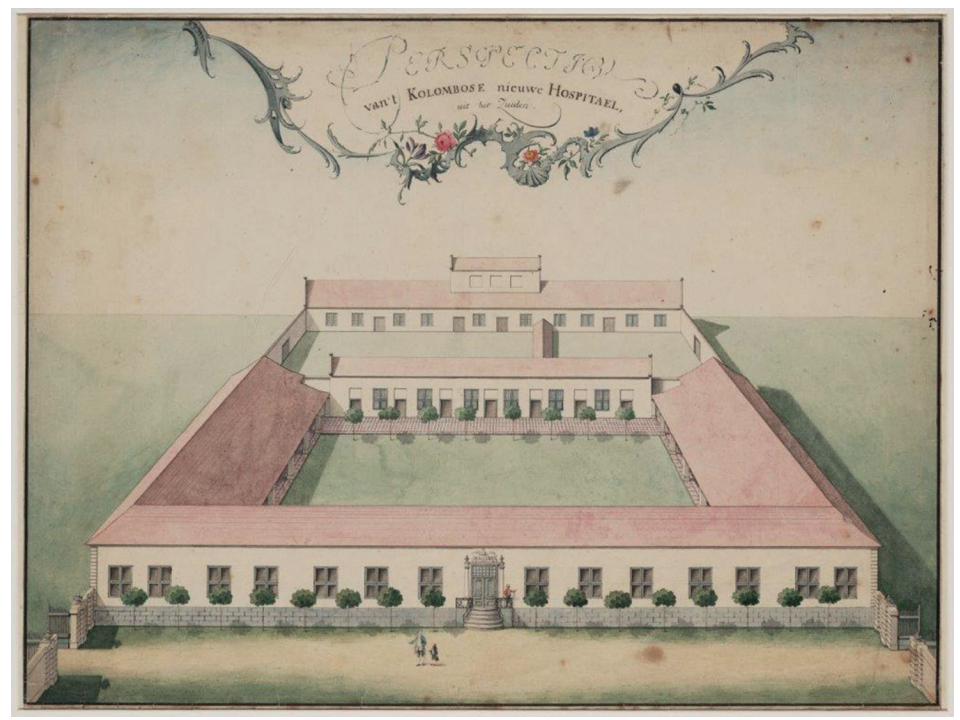

Figure 1 The Old Dutch Hospital at Colombo (Source KITLV)

\section{General hospitals on Java}

As set out in the Introductory chapter ( $\$$ Conceptual framework), an essential distinction in this book is the one between general hospitals and specialized hospitals. General hospitals aim at treating all kind of diseases, utilizing many kinds of medical specialists. Specialized hospitals take care of only one type of disease (e.g. leprosy, beriberi) or practise one type of medical specialism (e.g. gynaecology, ophthalmology). In the next sections of this chapter, we will meet the general hospitals as most common type of hospitals, whereas a few specialized hospitals will be presented as well.

During the VOC era and quite some time afterwards, Java was the main island and the other islands were less important from the point of view of commercial interests and related functions. This is why I make a distinction between Java and the group of other islands, initially taken together under the name Buitenkantoren or Outer Establishments, later on named Outer Islands or Outer Provinces as the most common distinction.

\section{The Sailors' Hospital (1617-1790)}

Most likely, the first hospital ever established in the East Indies, according to Swaving, was a building in front of the Dutch Loge. It was located not far from the town of Jayakarta and adjacent to a trading post in which a garrison of about 100 soldiers was located. This hospital was destined "voornamelijk voor schepelingen" (mainly for sailors).

Governor-General J.P. Coen decided to remove the hospital and the bamboo huts for patients and workers to the nearby island of Onrust. At the same time, a reduit (fortified 
structure) was established on this island. ${ }^{32}$ The removal took place, while the town was under attack from the people of Mataram. ${ }^{33}$

Schoute describes the outbreak of an infectious fever in 1790 . He mentions that that time there were a ziekenvader (male superintendant) and a doctor, working in a primitive small hospital, in a brick barrack. ${ }^{34}$ Because of their fevers and the inadequate facilities, the patients were removed from Onrust to the island of Purmerend. In the leprosy building on that island a dividing wall was erected to separate the leprosy patients from other patients. ${ }^{35}$

\section{The Company's Hospital at Batavia (1619-1640)}

The Hooge Regeering at Batavia mentioned this hospital in a resolution of 22 September 1622. In this document, the authorities stated that Hendrik Goch from Düsseldorf, who had been sailing with the "Amsterdam" as an opperbarbier (Chief barber) and who functioned in the sieckenhuys (hospital) at that moment, was hired again for 43 guilders per month after his first term had expired. The reason why this hospital was needed, was formulated as follows by Iris Bruijn: "In Asia, caring for the sick was a dire necessity: as the majority of the Company's employees were comprised of a floating population, arriving or leaving with the fleets, the sailors and troops had neither permanent housing nor kith and kin to turn to in times of illness and therefore had to rely on the Company for help." ${ }^{36}$ The Company's Hospital was intended to function mainly for soldiers and sailors from newly arrived ships. The VOC authorities usually sent the permanently disabled patients (incurables) back home. ${ }^{37}$

At its start, this Company's Hospital was a small wooden building, located in the old fortress. Later three hospital buildings were constructed in succession. In 1622, the first hospital was made of bamboo and atap and built outside the castle. This building soon appeared to be in a dilapidated state. It was replaced in 1626 , but this one became a prey to the many raids by the Javanese from Mataram. It was pulled down together with a large part of the town as part of the defence measures against the attacks by Sultan Agung, ruler of Mataram. Following the closure in 1632, it was decided to build a new hospital in the former church square, north of point Hollandia, but it took 8 years before this project was finished. A temporary facility was built and used until 1640, in anticipation of the Binnenhospitaal (City Hospital) to be built. ${ }^{38}$

32 Originally, the island housed a shipyard for the repair of VOC-ships. In more recent times the island successively housed a sanatorium for tuberculosis patients and a quarantine station for haj pilgrims.

33 C. Swaving, "Batavia's sanitaire geschiedenis onder het bestuur van de Oost-Indische Maatschappij." Ned Tijdschr Geneeskd $22(1878) 6$.

34 In Health care in Java, Rosalia Sciortino distinguishes between binnenvaders/ziekenvaders (male superintendants) and ziekenoppassers (male sick-attendants).

35 Schoute, De Geneeskunde in den dienst der OIC, 307-309.

36 Bruijn, Ship's Surgeons, 96.

37 Ibidem, 97.

38 D. Schoute, De Geneeskunde in den dienst der OIC, 111-113. 
The first surgeons mentioned were Pellegrom Pietersz and Hendrik Goch from Düsseldorf. The latter was re-appointed as chirurgijn of the company's hospital. A year later the ziekentrooster (patient comforter) Michiel Seroyen applied for a promotion to hospitalminister. ${ }^{39}$ The Regent or Opsiender (director) was then Adriaan Bouwens from Delft. Jacob de Bondt (Dr. Bontius) from Leiden was appointed as physician, chemist and supervisor of the Company's medical personnel in 1627. Little information is available about the then prevailing nursing system. Rosalia Sciortino concludes that the Company tried to reproduce the domestic nursing system of the homeland, which consisted of a hierarchy of binnenvaders/ziekenvaders (male superintendants) and ziekenoppassers (male sickattendants). Referring to a few remarks of Schoute on this issue, Sciortino assumes that the superintendants (wardens) were male European employees, while the attendants were local male slaves. ${ }^{40}$

\section{The Binnenhospitaal (City Hospital) at Batavia (1641-1808).}

It was in the afternoon of a rather hot and humid day, when Governor-General Antonio van Diemen laid the foundation stone for the Binnenhospitaal in Batavia, situated between the Nieuwpoortstraat and the river (West and East-side) and the Inner City canal (south) and the Kerkstraat (north). It was the first of August 1639 and as the history tells, the new hospital was to serve the Batavia people from 1641 till 1808. It is true that the word "serve" was not entirely appropriate in this case, because the regulations of this hospital showed a rather harsh regime for its inmates: If they absented themselves from the twice-a-day held praying sessions, they were eligible to receive 25 blows as a punishment. Even more significant was the reputation that the hospital acquired for its high mortality rate.

The physician C. Swaving describes the hospital buildings meticulously: The hospital could accomodate approximately 300 patients, who had $10 \mathrm{~m}^{2}$ space available on average in a building of 875 square roeden $\left(3282 \mathrm{~m}^{2}\right)$. Within the 8 feet high walls, toilets and bathrooms were erected next to the canal. On the north side, a two-storey building was constructed. The rooms in this building were well ventilated and available for the medical staff and the housemaster. The auxiliary staff was lodged elsewhere on the premises. The ground floor, usually the least airy part of a building, was designated for the patients, who were accommodated in 80 beds or more, alongside the walls. The walls had only two windows, in the centre, to let in light. At one end of the wall (As can be seen from Figure 2), there was a door and next to the roof there were 13 small openings and 7 windows. ${ }^{41}$

39 J. de Niet, Ziekentroosters op de pastorale markt, 1550-1880 (Rotterdam 2006): Ziekentrooster or krankenbezoeker was a function in the context of religious offices. The distinction between a hospital-minister and a visitor of hospital patients was fluctuating, depending on demand and supply in the pastoral market.

40 Rosalia Sciortino, Care-takers of cure: a study of health centre nurses in rural Central Java (Amsterdam 1992) 50-51.

41 Swaving, "Batavia's sanitaire geschiedenis",156-170. 
Regrettably, this construction precluded the necessary ventilation alongside the ground floor. Later when the hospital received far more patients than the planned 300, the necessary expansion had to be found within the existing walls. The hospital regents did not permit to buy additional building land. More than a century later, in 1769, the appearance of the hospital had changed fundamentally. Some of the buildings had upper floors and plans existed to accomplish this for the other buildings too. A budget of 5,587 rijksdaalders (about $f 14,000$ ) was sufficient to effectuate these improvements. The extensions consisted of 1,500 $\mathrm{m}^{2}$. The old and new buildings of the City Hospital could lodge 1,050 impotenten (sick people).

Van der Brug summarizes the qualities of this notorious hospital, in which more than 160,000 Company servants died: 'It was a morose, damp and badly ventilated building in an unhealthy environment. It served more than one and a half century and was nicknamed the Murder Pit Hole.42

At the completion of the hospital, a statute was issued on the $1^{\text {st }}$ of February 1639 in which it was stated that the abuses of the past should be avoided. Therefore, the housemaster and the three regents had to check that no one was admitted who left his service being lazy or affecting some illness. Once a week the supervisors had to participate in the medical visit and dismiss those who were considered capable of fulfilling their duties in the Company. ${ }^{43}$ The daily medical procedure in the City Hospital is depicted colourfully by the VOC architect and draftsman in the mid- $18^{\text {th }}$ century, Johann Wolfgang Heydt. ${ }^{44}$ He observed:

Early in the morning the doctor and 1 or 2 ziekenvaders (ward-masters) arrive, accompanied by several slaves, who carry the slates on which the doctor notes the number of the bed and writes down the prescription. The hospital is subdivided in buildings that house the normal sick (Internal medicine), the patients with injuries and fractures (surgery), patients with infectious diseases like dysentery, and a fourth building for venereal diseases. As soon as all prescriptions are written down on the slate tablets, these tablets are taken to the Apotheek (pharmacy), where plumb or zinc mugs are filled with medicaments and provided with the number of the patient. After the visit has been completed, the "Verband" (treatment) session takes place in which patients with injuries and fractures get the treatment the surgeon judges to be right. Without consulting the patient on his condition the surgeon starts to bandage, cut or cauterize. The patient who resists this treatment will be held tight by some slaves and if necessary gets some slaps in the face to make him cooperate.

42 Van der Brug, Malaria en Malaise, 47-48.

43 Statuten van Batavia (Statebook of Batavia) of July 1642, issued by Governor-General van Diemen, 472-594.

44 J.W. Heydt, Heydt's Ceylon (Colombo, 1952), 149-150. His story is part of the relevant sections of the Allerneuster Geographischund Topographischer Schauplatz von Africa und Ost-Indien. 
This eyewitness account appeals to the imagination and seems rather damaging for the hospital's reputation. There were some positive reports though, like the one of Joan Nieuhof. This author wrote that the patients all had nice beds and rooms and were surrounded with a square in which many trees were planted to "verlusting en verquikking" (entertainment and refreshment) and they could stroll towards the river and take a bath. ${ }^{45}$ There were more eulogies on the hospital, but after the 1730s all positive comments ceased in the face of the high mortality rate. Because of the appalling situation of the City Hospital, the NI Government decided to establish a new hospital south of Batavia. This decision was taken by Governor-General von Imhof on 23 August 1743. Because of its location, this new hospital was called the Buitenhospitaal (Outer City Hospital).

When comparing the City Hospital with the Colombo Hospital in Ceylon, some similarities may be observed: both hospitals had court yards and were composed of 1 storey buildings around a square. Both had a small upper floor, not destined to lodge patients. The notable exception that characterized the City Hospital in Batavia was the lack of verandas. The authors describing the Colombo Hospital mentioned the long and wide open verandas along the length of each wing as being characteristic of old Dutch architecture in the tropics.

\section{The Buitenhospitaal (Outer City Hospital) at Noordwijk (1743-1836)}

The High Government at Batavia received many reports concerning the causes of the high mortality in the City Hospital. Ultimately, it took the decision to build a new hospital, outside the town. The garden of the merchant Sybrand Hames was bought and this became the location on which this new hospital, the Buitenhospitaal (Outer City Hospital), was built. The decision was taken in $1743 .{ }^{46}$ By that time the City Hospital had a capacity of 600 beds, but often accommodated 1500 patients at-a-time.

In the course of 1743, preparations were made to build the new hospital at the fortress Noordwijk, 5 paalen (about $7.5 \mathrm{~km}$ ) from Batavia. The total investment, building costs together with land and slaves, came to $f 34,080 .{ }^{47}$ In 1756 , the average number of inpatients of this new hospital was 240 .

As the remuneration of the staff of both hospitals (City Hospital and Outer City Hospital) depended to some extent on the number of patients, there was rivalry from the start between the two hospitals concerning the distribution of patients. After the completion of new buildings, the ratio of patients from 1768 onward in the Outer City Hospital and the City Hospital shifted in favour of the Outer City Hospital and ultimately became $1200 \div 800$. The capacity of 2000 beds for these two hospitals hardly seemed sufficient to meet the high

\footnotetext{
45 Joan Nieuhof, Gedenkwaerdige Zee-en Lantreize. Transl. Memorable Sea and Land Voyages, 201

46 Government Decrees of 15 and 23 August 1743.

47 Schoute, De Geneeskunde in den dienst der OIC, 223. The $f$ sign stands for florin, the Dutch currency guilder.
} 


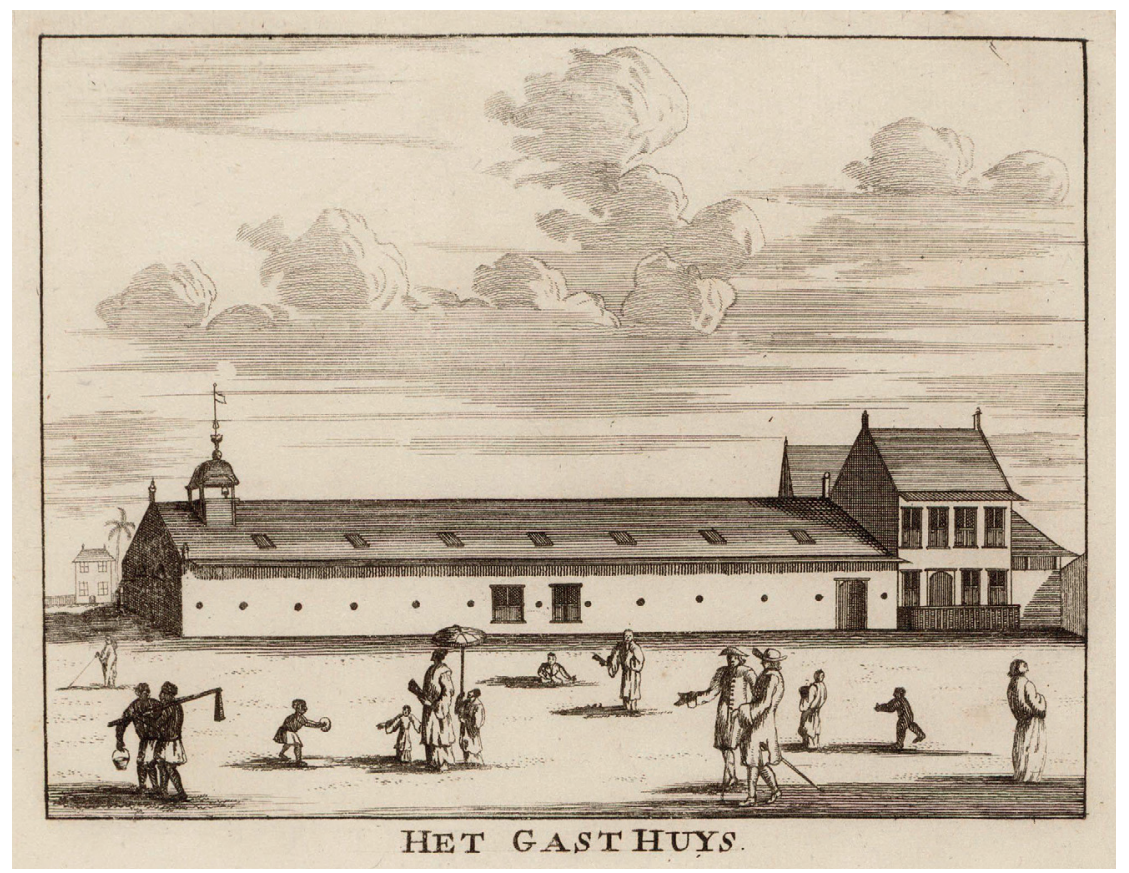

Figure 2 City Hospital 1682, Source: Westfries Museum.

number of admissions and the high mortality among seamen, military and VOC staff. ${ }^{48}$ With respect to the design and construction specifications of the Outer City Hospital, most information can be found in Swaving's publication. It seems that the new hospital was built at a rather slow pace. In 1761, 18 years later, the building was renovated and the wooden construction was replaced with a brick building, which could lodge a maximum of 250 patients. Together with a wooden extension built in 1768 and a two-storey brick barrack, completed at about the same time, the Outer City Hospital could accommodate 1,200 patients. ${ }^{49}$ Swaving mentions that the official standard size for hospital rooms was $17.5 \mathrm{~m}^{3}$ per patient, while the dimensions of the new barracks allowed for only $8 \mathrm{~m}^{3}$. This author thinks that this hospital never met the demands of a hospital that was to accommodate 1,200 patients.

Still, from about 1790, the Outer City Hospital became the main hospital for the VOC servants at Batavia and from this time the regulations of the Outer City Hospital were applied to the functioning of the City Hospital as well. The costs of living and medicine

48 Schoute, De Geneeskunde in den dienst der OIC, 175-189.

49 The materials to realize the building took an amount of 2,600 rijksdaalders $(f 6,500)$. The new two-storey building had a covered walkway, had a tile floor and roof and a surface of about 4,200 $\mathrm{m}^{2}$, apt for 560 patients. 
in the City Hospital, the amount each day per patient was reduced to the level of the Outer City Hospital. This meant that 8 stuivers were available for a maximum of 600 impotenten. Gradually this was reduced to 6 stuivers, if and for as far as the number exceeded 1000 patients per day (4 stuivers for costs of living and 2 stuivers for medicines). ${ }^{50}$ The City Hospital was closed in 1808 and its patients were removed to its former competitor, the Outer City Hospital, which in turn was closed in 1836 and had to move its patients to the military hospital at Weltevreden, a suburb farther to the south of Batavia.

\section{The Hospital at Bantam (about 1682-1817)}

Schoute concludes from the writing of a surgeon by name of Frikius from Ulm who left for the Indies aboard the ship "Ternate" in 1681, that there was a hospital at Bantam by that time. ${ }^{51}$ Frikius was posted to this hospital during the expedition against Bantam of 1682 . The hospital he describes was located in front of the Castle De Diamant, in the town and near a square. It was unable to meet the volume of care and treatment required for a large number of soldiers who were sick or wounded, since there was only 1 opperchirurgijn and 5 onderchirurgijns employed at that time. Most of the patients had to be transported to Batavia until an extension was built. In 1755 the military force in the fortresses Diamant and Speelwijck amounted to 386 men. The hospital capacity was at that time intended for 12 patients per day on average and the annual expenditure after deduction of the wages of its patients amounted to $f 792 .{ }^{52}$ From about the turn of the next century, a decision taken by Governor-General J. Siberg indicated that the salary of the "hospitalier" at Bantam was fixed at 100 rijksdaalders, paper money, per month, 'met intrekking van alle andere voordelen' (all other allowances being revoked)..$^{53}$ The date of this decree was $7^{\text {th }}$ January 1803.

In summarizing Residential reports in the period 1823 - 1845, Schoute mentions that the officer-in-charge of health at Bantam, van Zonst Zeldenrijk, had often insisted on improving of the local hospital. Apparently in vain, since the hospital was blown down by a storm in 1817 .

\section{The Hospital at Semarang (1776-1836)}

Schoute mentions the existence of an independent hospital at Semarang, but the exact date of its founding is not established. As Semarang was an important town, it could boast of a rather big hospital. A considerable refurbishment of the buildings took place in 1776, when the hospital was enlarged and renewed. The reports mention a solid and strong

\footnotetext{
50 W.A. Alting "Bepalingen nopens het buitenhospitaal at Batavia van 19 April 1793" in: J.A. van der Chijs ed., NederlandschIndisch Plakkaatboek 1602-1811 (Batavia 1900) 525-526.

51 Schoute, Occidental therapeutics, 34 and 40.

52 Schoute, De Geneeskunde in den dienst der OIC, 293.

53 J.A.van der Chijs, Nederlandsch-Indisch Plakkaatboek 1602-1811, volume XIII, 565.
} 
building, which would function for a long time to come. However, within the next ten years, the original purpose of the building was changed into a naval college. This change in function did not occur because of the buildings deteriorated, but was due to changed conceptions about hospital construction and hygiene. F. A. Bonneken, one of the hospital's surgeons, started a discussion about what was required of a hospital. Bonneken argued for the necessity of sufficient ventilation, enough room per patient and a dry and solid construction. He considered the existing hospital unsatisfactory: the buildings were low storied, damp and badly located. This made the hospital a hotbed for disease. His list of grievances was extended to insufficient protection of the patients against rain and wind, bad floorings of bricks, remoteness of lavatories outside the house and old dilapidated kitchens. The report stated the uncontested opinion in that time that the danger for the patients was closely associated with the quality of the air. Infected air generated disease, a reason why stench above all was held in horror. Schoute concluded his report by remarking that the maxim of pure air would influence therapeutics in the Indies yet for a long time to come. ${ }^{54}$

A new hospital of 400 to 500 patients was inaugurated at Semarang in 1787, thanks to a donation of the late Governor of Java's North-East Coast, Johan Siberg, of buildings and land. ${ }^{55}$ This hospital was situated in the town centre. The building budget amounted to $f$ 40.000. The building was situated in front of the benteng (fortress), next to the "oudemanhuis" (old men's home), and the garden of Mr. Sunnet at the south side of the town. The new location was considered a healthy place. It had two storeys each with four wards and ample room for patients and was at that time a model of hospital architecture in the Netherlands Indies. ${ }^{56}$ In 1793, at his death, the former Governor of Java's East Coast Jan Greeve bequeathed a sum of 30,000 rixdaalders to the Semarang Hospital. ${ }^{57}$ Later this Company's hospital became a military hospital, when H.W. Daendels (1808-1811) was appointed Governor-General by the Bataafsche Republic.

\section{The Hospital at Soerabaja (1780)}

Soerabaja had been a rather insignificant town in VOC-time and so it had a very small health facility with only 3 chirurgijns to care for its patients. In 1780, the Governor of East Java referred to the considerable repairs to the Soerabaja hospital in a report to his successor. The hospital was located in the centre of the town and was sold in 1808, after Daendels decided that it should be replaced by a new hospital that could take care of a greater number

54 Schoute, Occidental Therapeutics, 61-62.

55 How could a VOC-functionary afford this generosity? According to Gonggryp (p.1292) the Governor was unreliable and promoted in particular his own interests and Furnivall (p. 64) calls Siberg one of the most corrupt members of the old gang who had been content to line his own pockets.

56 D. Schoute, "De geneeskunde in Nederlandsch-Indië gedurende de negentiende eeuw" GTNI 74 (1934) and 75 (1935) 1018,1098 and 1367.

57 Schoute, Occidental Therapeutics, 87. 
of patients, both Europeans and indigenous. The new hospital had a military function: it became one of the three main military hospitals on Java. The new location was at the left side of the river Brantas, not far from the bridge to the kampong Genting.

\section{The Hospital at Cheribon (1778)}

In 1778 a new hospital at Cheribon was proposed, but the new buildings were needed to replace some health care facilities within the local fortification that had to be demolished. Eventually, the new hospital was built and a few decades later GovernorGeneral H. W. Daendels issued an instruction to the "schrijver en hospitaalmeester" of the hospital at Cheribon. ${ }^{58}$ Later, in the $19^{\text {th }}$ century, this hospital was replaced by a Stadsverband (City Dressing Station), by which the municipality of Cheribon cared for local patients.

\section{General Hospitals in the BuitenKantoren (Outer Establishments)}

Although the first strongholds of the VOC and also the residencies of some of the first Governors-General were to be found in the Moluccas, the first hospital was on Java. We already mentioned that the founding of hospitals depended on the size of the population of the settlement. Before starting a hospital, patients were lodged in fortified places within the Castle or benteng. This was also the case on Ambon, Ternate and Banda, where the Dutch tried to establish a spice monopoly. Following a period of warfare and struggle, the settlement seemed stable enough to organize facilities outside the Castle, including hospitals. This same course of events happened on Celebes, where admiral C.J. Speelman (1628-1684) conquered Makassar in 1667. It took about 50 years before the situation was stable enough to build a hospital outside Fort Rotterdam. In the course of the $18^{\text {th }}$ century there was a commercial post on Sumatra as well, but of minor importance because the trade suffered from competition with the British. Altogether, five general hospitals existed outside the island of Java during VOC-time.

\section{The Hospital on Ambon (1648)}

Valentijn mentions the building of the oud Siekenhuis (old hospital) on the river Way Tomo. ${ }^{59}$ According to Valentijn, the old hospital had been built under Governor Vlaming in 1648. It was expanded and restored in 1674 and completed in 1702. Schoute wrote that the destruction of part of the old hospital occurred with an earthquake in 1674. Two new hospitals were built, one in 1679 and the other after 1692. The latter was built on the opposite side of the same river. The new hospital had been designed in a square shape, 150

\footnotetext{
58 Van der Chijs, NI Plakaatboek 1602-1811, Volume XIV, 821-822.

59 Valentijn, François, Beschrijvinge van Oud en Nieuw Oostindiën, vol. II. (Dordrecht 1724) 128-134.Transl.: Description of the Old and New East Indies (Dordrecht 1724).
} 
feet wide and 150 feet long. The front wall was 14 feet high. A large garden was situated in the centre of the square. Because of the danger of earthquakes, it had only one storey and was built on a stone base with wooden walls. One wing was assigned to the hospitalier, the chief surgeon in charge, and the other three wings had wards for patients and auxiliary services. Ventilation and safety defined the choice of the location. The hospital had to be within range of the castle's artillery for reasons of defence. Next to the hospital, a large area was destined for cemetery.

Both the Castle Victoria and the hospital had an opperchirurgijn in command. The medical head of the castle was highest in rank and supervised the chirurgijns and onderchirurgijns. Further, he was in charge of the distribution of medicines. The social rank of the opperchirurgijn came close to that of an Onderkoopman (junior Merchant), which may be compared to lower middle class.

According to Valentijn, the total strength of the VOC personnel of Ambon was 950, in $1700 .^{60}$ This number included the military (614), the religious and educational personnel (70), the merchants and bookkeepers (51). The medical staff of Castle and hospital together amounted to 17 people. Schoute mentions a total number of 31 chirurgijns for the entire Moluccas Archipelago and 8 surgeons for Ambon in data presented about $1755 .^{61}$

\section{The Hospital on Ternate (1658)}

According to Schoute, a reasonable hospital must have existed on Ternate. He mentions three stones with inscriptions, embedded in a wall of the fort Oranje on Ternate. The central stone contained the name of the Governor of the Moluccas, Simon Cos, and the date 1658. The other stones were placed above the pharmacy and the entrance to the hospital and gave the function of the building in Latin. During the $17^{\text {th }}$ century, no other information is available concerning building, activities, staff or patients. The data Schoute collected for 1755 mention a medical staff of 5 surgeons. In 1756 the Governor of the Moluccas complained about considerable expenses during the last forty years. In 1766 it was decided by the Council of the East Indies that a grant would be given to construct a new hospital. The new hospital would be built within range of the fortress' guns, it should be solid, strong and spacious and the floors were to be laid above the ground to ensure healthy living conditions for the patients. In the meantime, the number of the patients had increased to a daily average of 60 . Reports mention that most of the patients suffered from wounds and ulcers. Accommodation and food were improved in 1787. In a report by the Commissioner

\footnotetext{
60 Valentijn describes a total male population of Ambon of 22,231 in 1700. Including women and children he arrives at a number of 78,220 in this year.

61 Schoute, Occidental therapeutics, 65.
} 
of the Civil Medical Service, J. Bowier, a few decennia later, a military hospital is mentioned in which 60 patients could be hospitalized. The building was well-kept and suited for its purpose. $^{62}$

\section{The Hospital on Banda (about 1664)}

Before a hospital was established, the patients were attended to in the fort Nassau. GovernorGeneral J.P. Coen wrote in 1618 that many patients had fevers and that about 90 men of the garrison died due to fevers. Valentijn mentions that there were an opperwondheeler (senior surgeon) and several onderwondheelers (junior surgeons) who served in the hospital, the castle and the shipyard. They also served the civilian population of Banda. Except for the senior officials, patients had to pay for services rendered. There were also onderchirurgijns available on the islands of Lonthoir, Poeloe Ay and other VOC settlements. ${ }^{63}$ In 1756 a report about the Moluccas observed that attention needed to be paid to the Banda Hospital and that the patients were not well cared for there. In another report in 1756, it appears that the hospital was fit to nurse some 54 patients. At that time the hospital regime was unfavourable for patients, as they suffered from the "schraapzucht van een onbarmhartig schaftwyf" (the avarice of a merciless female housekeeper). At that time Banda was in a poor economic state, because of receding trade. ${ }^{64}$ In 1793 investigations of the state of various hospitals of the Company led to recommendations in which the Banda hospital profited from an increase in the outsourcing tariffs: for boarding 8 stuivers for each patient per day and for washing 10 stuivers for each patient per month. ${ }^{65}$ The report of the Medical Commissioner J. Bowier of 1819 mentions a large military hospital on Banda, able to nurse about 100 patients in a rather well elevated, ventilated and preserved building, outside the town.

\section{The Hospital at Padang on Sumatra (1690)}

According to Schoute, a hospital existed at Padang around 1690. This hospital was most likely situated inside the fortress, since the situation outside was much too turbulent. No information is available about the date of its foundation, though it will have been in the second half of the $17^{\text {th }}$ century, since Padang became a centre of administration for the West-Coast of Sumatra not before 1692. In the $18^{\text {th }}$ century there were complaints about the number of patients that were sent from the hospitals in the Outer Establishments, like Padang, to Batavia, under the pretext that these patients were incurable. Notwithstanding this practice, the costs of medical care increased in the course of time and beyond an

\footnotetext{
62 Schoute,"De Geneeskunde in NI", GTNI 74 (1934) 20, 1370.

63 Valentijn, part 3B, Book 1, Chapter 6, 88.

64 Schoute, Occidental therapeutics, 40, 64.

65 Schoute, De Geneeskunde in den dienst der OIC, 289- 291.
} 
acceptable level for the authorities in Batavia. In the year 1751-52 the expenses had amounted to 5,364 guilders. There were only 10 patients on average. In 1761 the chief surgeon of the hospital asked for an increase in salary, while reporting that there were only five to six patients on average present in the hospital. ${ }^{66}$ About that time, two surgeons were posted at Padang, two at Palembang, one at Sinkel and one on Pulo Chinco. In total Sumatra counted six surgeons.

\section{The Hospital at Makassar on Celebes (1699)}

A similar account may be given about the hospital at Makassar. Admiral Speelman conquered Makassar with the help of Bugis troops in 1667. But after the submission of the ruling kingdom, the region was unstable for quite some time and building a hospital outside the walls of Fort Rotterdam was out of the question. In 1715, when the situation had stabilized, Batavia was asked for permission to build a proper hospital outside the fort. The new hospital was situated at the west of the fort and was built in a square shape, each wing about 60 meters. The hospital obviously met the needs of the local population, for reports mentioned that the bed occupancy was over $100 \%$. In the meantime, the hospital expenditure had increased to $f 8,453$ by 1737 , a seven-fold rise in the amount needed 40 years previously. In 1781, the place was reported to be filthy and the patients badly cared for. An investigation took place and appropriate measures were taken. The daily amount of food and drinks for each patient was raised to 6 stuivers and the amount for washing was increased to 10 stuivers for each patient per month. ${ }^{67}$

\section{General Hospitals for specific groups}

Some general hospitals were founded for specific ethnic groups and for poor indigenous patients. It should be kept in mind that the hospitals mentioned above, mostly served European VOC personnel, European sailors and soldiers.

The next paragraph will discuss successively the Chinese, the Moorsche and the Diaconie hospitals.

\section{The Chinese Hospital in Batavia (1640-1912) ${ }^{68}$}

The Chinese Hospital dates from 1640. It was a general hospital, founded and financed by Chinese for the Chinese community. Later on, it was also used to lodge psychiatric patients. ${ }^{69}$ The Chinese population group in Batavia was referred to as a nation. This nation had a leader, the captain, who was one of the most prominent Chinese residents.

66 Schoute, Occidental therapeutics, 62.

67 Schoute, De Geneeskunde in den dienst der OIC, 289-291.

68 Schoute, De Geneeskunde in den dienst der OIC, 145-146 and 193.

69 This hospital was formally closed in 1912 (Stbl. 1911, no. 585) and taken over by the government to function as an auxiliary City Dressing Station. 
In 1640, the Council of the Indies passed a resolution to appoint four executors of Chinese estates. They were called the Boedelmeesters (estate administrators). The Council appointed two Dutch and two Chinese to make an end to the endless disputes concerning inheritances. These Boedelmeesters soon made a request to permit the foundation of a separate hospital for the poor sick Chinese and to be maintained by voluntary and free contributions of the Chinese nation. This voluntary contribution did not work out well and so the Council decided later that a special tax should be levied on Chinese inheritances in favour of the hospital. The treatment of patients was given by Chinese doctors and the VOC provided an indemnification of 10 realen per month for the attendance of Company employees. In 1661 the building was ruined and a new building had to be erected.

The architect (then called fabryck) was Jan Sterkenburgh, who designed the buildings of the company and who conceived een vast gebou van steen ende calck (a solid building of brick and lime). This hospital was built at the Rhinocerosgracht next to the spinning-house. In 1740, the entire hospital population was murdered, together with all the Chinese of Batavia in a riot that lasted for 3 days in October that year. It took several decennia to recover from this disaster, but in 1770 financial means improved and in that year the number of patients had increased to 86 . Some years later, in 1776, part of the women's house of correction (spinning-house) was integrated into the hospital in order to obtain more suitable rooms for the isolation of insane individuals. From that time, the mentally ill, including the Mohammedan community, were housed in this annex. ${ }^{70}$

\section{The Moorsche Hospitaal (1751-1785)}

The town of Batavia and its so-called Ommelanden consisted of many ethnic groups among its population. Among them were the Indian Muslims, called Moors. In 1750, GovernorGeneral J. Mossel (1750-1761) decided to establish a hospital for Moorish sailors. This was to prevent these sailors from roaming about under the pretext of being ill. Instead of acquiring work as VOC servants, many of these sailors went out to beg for alms or tried to get work in the sugar mills. The hospital was built near the fortress Jacatra on a piece of VOC land at the Tankévaart. It did not look like a hospital, but had more the appearance of a large stone barn. According to reports, it housed 50 patients in the year 1756. The treatment of internal cases was entrusted to an indigenous surgeon (called practician) and two auxiliary practicians. Some of the sailors, when recovered from their disease were invited to join the hospital staff as a cook, ziekenvader (patient attendant) or for other functions. ${ }^{71}$ In May 1785 Governor-General W.A. Alting decided to close this hospital, because of the small number of remaining Moorish sailors.

70 Schoute, Occidental Therapeutics, 39 and 82.

71 J. Mossel, "Reglement voor het Moorsche hospital bij het fort Jakatra van 7 December 1751" in: J.A. van der Chijs ed. Nederlandsch-Indisch Plakkaatboek 1602-1811 (Batavia 1900) 114-118. 


\section{The Hospital of the Poor Relief Board (1635- mid $19^{\text {th }}$ century)}

The Poor Relief Board (Diaconie) at Batavia acquired ample means since 1630 and decided to do something for the native community. According to Schoute this was the first initiative to cope with the health problems of the poor and sick population of Batavia and its surroundings. ${ }^{72}$

The institution had a dual character: an orphanage and a hospital for the poor. In the beginning 14 orphans were admitted. Later on, a growing stream of emancipated slaves sought shelter within this institution, joined by the wounded persons who used to be treated in the private home of the City Surgeon. The building was situated on the eastside of the distinguished Tijgersgracht. About 1639, this building was replaced by one made of brick. The new building replaced the one made of atap and bamboo for an investment of 3000 Realen van achten. ${ }^{73}$ In 1690, the number of patients had increased considerably and an adjacent house was bought to enlarge the institution. A married couple stood at the head of the establishment. They brought out weekly reports to the Board of Deacons concerning new patients. The Board of Deacons appointed Dr. Boraeus as medical doctor and Mr. Duraeus as surgeon. In 1686, the Board appointed one of the first indigenous surgeons to assist the medical staff.

During the $18^{\text {th }}$ century the significance of this establishment diminished. The Diaconie fell into financial difficulties due to the increasing costs and the limited means that could be collected. The Orphanage and Poor House still existed in the time of Governor-General Daendels, who, in 1809, decreed that four hospital wards should be kept in the Orphanage and Poor House: two for the dangerous and infectious diseases of both sexes and two for less dangerous patients. ${ }^{74}$ The institution was mentioned in the monthly reports of the years 1825-27 of its Binnenregent for the last time. ${ }^{75}$

\section{Specialized hospitals}

In addition to the general hospitals, a few specialized hospitals could be found in the VOC period. These hospitals cared for a certain group of diseases or offered a special treatment. In the next section two leprosy and one convalescent hospital will be discussed. Previously, we saw that the Chinese hospital took care of a special group: the insane. Later it more or less became the official institution to treat and care for psychiatric patients in Batavia for some time in the $19^{\text {th }}$ century. The Chinese hospitals were known as institutions that cared for leprosy patients as well.

\footnotetext{
Schoute, Occidental Therapeutics, 39.

31 Reaal van achten was a silver Spanish coin with a value of 60 Stuivers, about 3 guilders in the Dutch East Indies around 1630 .

74 Van der Chijs, Nederlandsch-Indisch Plakkaatboek 1602-1811, vol. III, 671-672.

75 Inventaris 2.4.2.1 Armenhuis. Arsip Nasional Republik Indonesia, Kerken te Batavia, inv.nr. 454.
} 
Leprosy was a disease that showed a continuous increase in Batavia as well as in the Moluccas during the $17^{\text {th }}$ century. Initially, leprosy had been considered to be very contagious, but little by little doubts arose. This meant that at first patients were isolated and brought to a place at some distance from towns and villages, preferably on an island. Later, in the course of the $18^{\text {th }}$ century, the establishments on the islands were abandoned because the patients returned to society and were cared for in general hospitals, such as Chinese hospitals. Leprosy patients could often be found in beggars' homes as well.

\section{The Lazarushuis or Leprosy Home at Purmerend (1665-1800)}

Swaving mentions the existence of the Lazarushuis (Leprosy Hospital) on the island of Purmerend near Batavia, dating from 1665 and originally built in the neighbourhood of the fortress Angke on the mainland near Batavia as the Gasthuis voor melaatschen. ${ }^{76}$ Later, because of the danger of contamination, the Gasthuis was moved from the town to the island of Purmerend. This move took place in September 1681. By 1689 and during the next decade, the number of patients with leprosy was usually between 160 and 170, but afterwards the numbers dropped continuously. ${ }^{77}$ The institution provided shelter to members of the indigenous population, slaves and sometimes to European patients. Some people, born on Purmerend, who had not been affected by leprosy, were allowed to live on the island of Edam and continue their VOC service. Henceforth the decision was taken to bring all the children beyond the age of eight, who were free from the disease, to the island of Edam. In 1790 the institution was visited by patients from the neighbouring island of Onrust: Patients from there had to be moved to more adequate facilities (see previous section about the Hospital for sailors). Apparently, the leprosy asylum was considered to comply with those standards and acquired a new ward for the Onrust patients. Not long afterwards, it was judged to be too dangerous to stay on the island. Because of the threat of a British attack, all the people had to be moved to Batavia. In 1800, the Leprosy establishment was indeed destroyed by the British. Fortunately, the last 13 leprosy patients had been transported to the Chinese hospital at Batavia in $1795 .^{78}$

\section{The Leprosy Hospital on Ambon (1699-1765) ${ }^{79}$}

The history of this hospital resembles that of the Lazarushuis at Batavia: at first an establishment arose in the town of Ambon, but had to be removed to a smaller island, Molanen. The leprosy home on the island was founded in 1701. From 1711 until 1714 the

76 Swaving, Batavia's sanitaire geschiedenis, 6.

77 P. Boomgaard, “The Living Dead: Leprosy in the Indonesian Archipelago, $17^{\text {th }}$ to $19^{\text {th }}$ centuries", paper for the workshop on Emergent Science and Technology Studies in Southeast Asia, Singapore, January 14-15, 2009.

78 L.S.A.M. von Römer, ed. "Over de ziekenverzorging en de geneeskundige hulp in Ned.Indië", in: Historische schetsen, een inleiding tot het vierde congres der Far Eastern Association of Tropical Medicine (Batavia 1921) 173.

79 Schoute, Occidental Therapeutics, 82. 
number of lepers increased from 74 to 100 . They came from far and abroad, even from Makassar. This town even contributed annually to the asylum. The Ambon church and the indigenous chiefs looked after its upkeep. The hospital was staffed by a derde chirurgijn (third surgeon), a corporal and four soldiers. Regent (Supervisor) was the chief of Saparoea. Like elsewhere in the Indies the number of patients decreased and in 1764 there was only one man, two women and six children left. In 1765 an attack by people from Ceram destroyed the hospital and killed one of the patients. Afterwards, it was restored and replaced by a new institution in $1853 .^{80}$

\section{The Convalescent Hospital at Tji Panas (1744-1761) ${ }^{81}$}

From 1744 till 1761 a so-called Buitenhospitaal (Convalescent hospital) existed at Tji Panas. This institution was created to relieve the then overloaded City Hospital. Its patients were sent there for a period of convalescence. It was founded when discussions took place about the building of the Outer City Hospital at Noordwijk near Batavia. The hospital at Tji Panas was a kind of Spa that served as a convalescent institution. The hot springs in the neighbourhood were used by the population to cure goitre. The wooden hospital was built on a hillside surrounded by woods and valleys. It was staffed by Neuman, an opperchirurgijn (chief surgeon) and an onderchirurgijn (second in charge). The building had two storeys, a covered walkway, a bathhouse and a pharmacy and was in demand by many sick people, inmates of the City Hospital. In the first years of its existence, work was started to improve the surroundings by creating gardens and enclosing the premises by fences. However, in order to arrive in the mountains required a difficult and strenuous journey of four days. Quite an organization was set up to regulate transportation. Besides a large number of Javanese bearers, 40 buffalo carts and 70 to 80 buffaloes were needed. In October 1752, the institution was set afire by people from Bantam. As soon as safety was restored, the fabrycq (architect) Hartkop was assigned to build a new house above the three baths for 1,000 rijksdaalders. The total capacity for patients was 30 . Although this institution became well-known and was soon praised because of its results, finally, its capacity was too small to support the overcrowded City Hospital. During its short existence the expenditure was $f 142,073$, an annual amount of almost $f 10,000 .{ }^{82}$ By the Resolution of 30 June 1761 the resort was closed. ${ }^{83}$

\section{SUMMARY}

Looking back at almost 200 years of VOC rule and its impact on hospitals, the following observations may be made.

80 Schoute, De Geneeskunde in den dienst der OIC, 180, 288-289.

81 Ibidem, 229-231.

82 Schoute, De Geneeskunde in den dienst der OIC, 240-243.

83 Schoute, Occidental Therapeutics, 83. 
At least 19 hospitals were founded and the medical provisions in terms of pharmaceutical facilities, finances and personnel had grown. Therefore, compared to other colonies, the Netherlands Indies took care of its personnel in a generous way, not economizing on the budgets of health care provisions. Still, looking at the vast archipelago, the hospital dots on the imaginary map were scarce.

\section{However}

- it never had been the intention of the VOC and the High Government to meet the health care needs of the indigenous population.

- Available means would never have met the needs.

Whilst the VOC was approaching the end of its existence due to debts, the investment in the hospitals in terms of improvement of buildings and budget increases was remarkable. A part of this increase was unavoidable in view of the ever increasing number of soldiers, sailors and craftsmen who needed to be hospitalized. Van der Brug calculates the higher expenses due to the necessary recruitment of new personnel and the increased hospital expenditure to be 900,000 guilders a year. ${ }^{84}$

\section{A few additional findings}

\section{Peoples and locations}

Altogether a total of 19 hospitals has been described, of which eight general hospitals on Java (Sailors' hospital, Company's hospital, City Hospital, Outer City Hospital, Bantam, Semarang, Soerabaja and Cheribon), five in the Outer Establishments (Ambon, Banda, Ternate, Makassar and Padang), three for specific groups (Chinese, Moors and poor indigenous people of Batavia) and three for special diseases (leprosy at Batavia and on Ambon and rehabilitation at Tji Panas). The Company's Sieckenhuys at Batavia, the Lazarushuys at Purmerend, the Convalescent Hospital at Tji Panas, the Leprosy Asylum at Ambon, the Moorish Hospital at Batavia and the Hospital for Sailors on the island of Onrust had all six been closed by the end of the $18^{\text {th }}$ century.

\section{Motivation}

the primary motive to found hospitals was to provide shelter and care for sick VOC servants (soldiers, sailors and other functionaries of rather low echelons) in order to make them healthy and able to continue their service. This was the paternalistic side of the VOC. A more business-like approach could be found in the attitude to prevent them ("this lazy bunch") from wandering around and escape their duties. Ultimately, the VOC wanted to preclude the necessity of organizing new shipments to replace dead servants. The Chinese wanted to

84 Between 1733 and 1795 a total of 65,000 VOC employees died in Batavia and 9,500 aboard the ships. So in order to keep things going an additional 74,500 young people needed to be recruited. 
take care of their old, poor and sick population. The Deacons wanted much the same: to take care of old, poor and sick indigenous individuals. Both examples originated from charity motives. The leprosy asylums were founded because of pressure from the population to protect citizens against the risk of contamination. And the Tji Panas institution was created to relieve the Binnenhospitaal from its overcrowded situation.

\section{Building styles}

At first, the provisions were housed in simple buildings made of local materials like bamboo, wood and atap. The establishments were placed within the enclosure of castles or fortresses, later on outside their protection, but sometimes still within the range of the fortress' guns. The design of the hospitals was simple and not always thoroughly thought out. That is why some hospitals suffered from a lack of ventilation. Besides, they had too many beds in cramped rooms and unhealthy surroundings. The City Hospital was such a case. The heads of VOC craftsmen, called fabrycq, designed hospitals like the "lasarushuys" at Batavia. ${ }^{85}$ The fabrycq Hartkop was assigned to build a new house above the springs at Tji Panas and the new 400 beds-hospital at Semarang (1787) was constructed according to the recommendations of one of its surgeons.

\section{Staff}

From the start, it was obvious that few doctors applied for jobs with the VOC in the Indies. Chirurgijns not only had to execute their normal occupation of surgery and treatment of wounds, they also performed tasks that were elsewhere exclusively reserved to doctors medicinae: treatment of internal diseases. In those places that had a medical doctor (the large towns), these doctors supervised the chirurgijns and had to be consulted concerning major operations. But in general, the chirurgijns performed all medical interventions and gradually became experienced doctors and surgeons. Before the ship chirurgijns or apprentices could obtain an appointment ashore, they were screened by a committee. Depending on the results, they were placed as opperchirurgijn, chirurgijn or onderchirurgijn. They were sometimes appointed Binnenregent, a kind of hospital director. This position was mostly entrusted to an opperchirurgijn. The chirurgijns were surrounded by a group of assistants, varying from krankbezoekers, ziekentroosters, schaftbazen or schaftwyven (housekeepers), ziekenoppassers (attendants), bookkeepers, cooks and slaves. 
MAP 1 HOSPITALS ARCHIPELAGO 1790

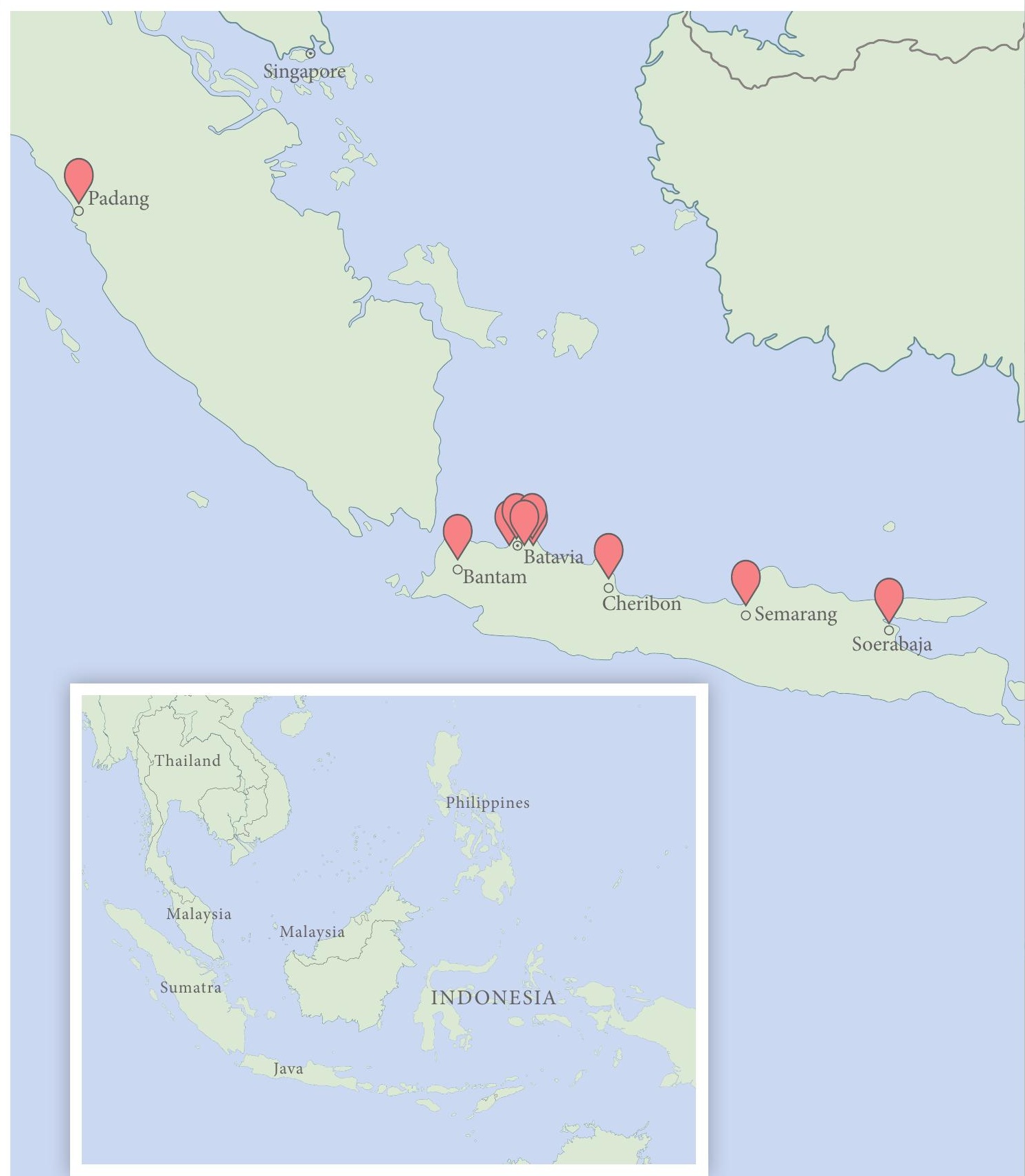




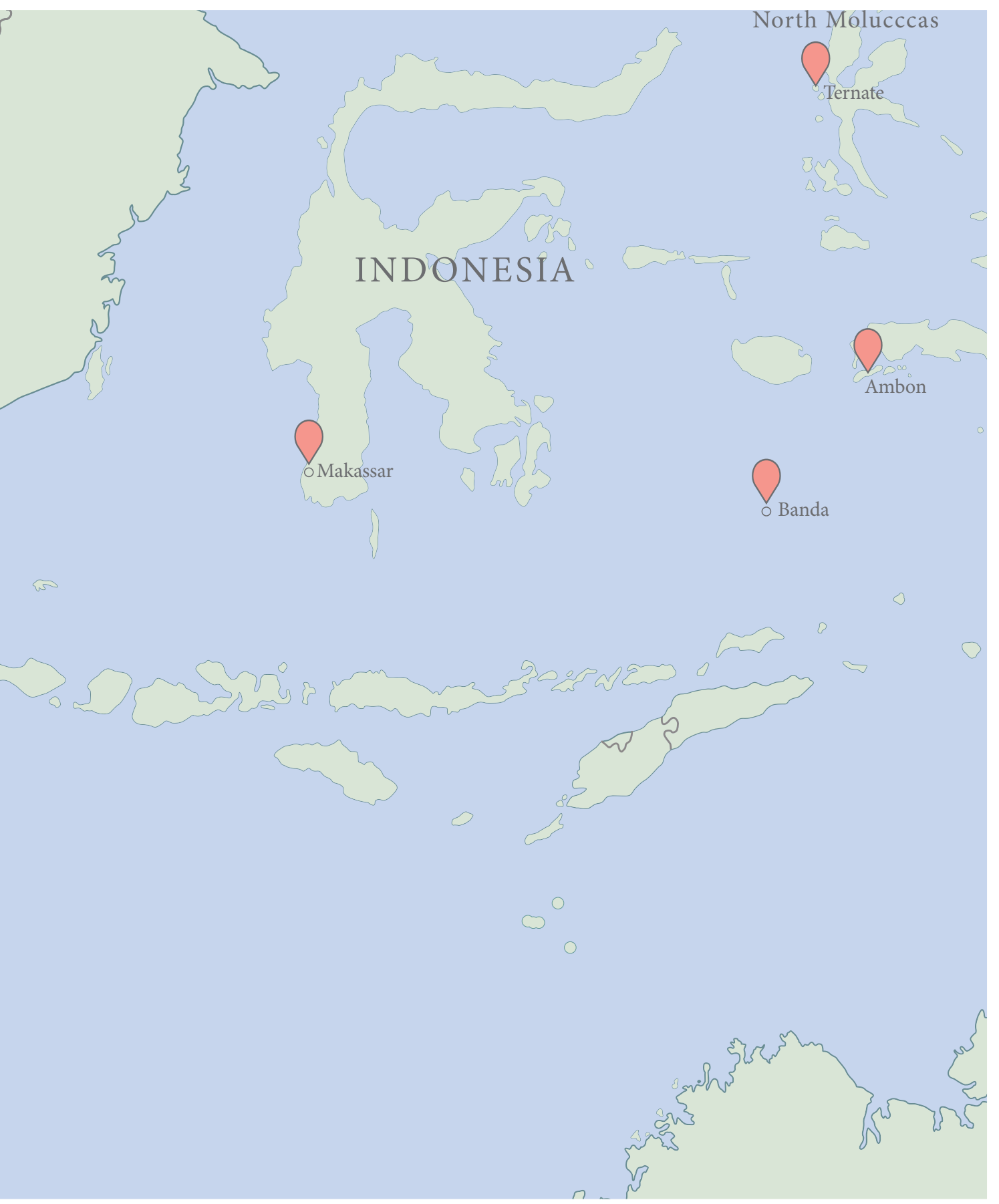





\section{CHAPTER 3}

\section{HEALTH CARE AND HOSPITALS IN THE 19TH CENTURY}




\section{INTRODUCTION}

In the VOC period, the Dutch Staten-Generaal (Estates General) transferred territorial authority concerning Asia to the VOC governing board, de Heeren XVII. This meant that the military and administrative power was in its hands. The combination of the distance and the limited means of communication meant that the Hoge Regering at Batavia held the real executive power. ${ }^{1}$ This situation changed after 1795.

In 1796, the VOC went bankrupt. The year before, the French had taken over power on the European continent. In the Netherlands, the Bataafse Republiek had been established and the Dutch stadhouder had been forced to leave, together with the ruling administrative establishment. New political organizations took over. The authority of the VOC was taken over by het Committé tot den Oost-Indischen Handel en Bezittingen (1796) and in 1800 by the Raad der Aziatische Bezittingen en Etablissementen. ${ }^{2}$ The main objective of these organizations was to economize on colonial expenditure. For this reason, they dismantled the commercial fleet that operated in the archipelago. At the same time, the British tried to take over the Dutch colonial possessions and succeeded in Ambon, Banda and West Sumatra. At the end of the 1790s, the colonial possessions were more or less paralysed and the same may be said about the commerce between the colony and the Republic. In the next 15 years, there were two developments that would greatly influence life in the archipelago. First, the appointment by King Louis Napoleon of Governor-General H.W. Daendels (1808-1811). Second, the conquest of Java by the British and the appointment of Lieutenant-Governor, Th.S. Raffles (1811-1815).

In 1816, the Dutch government reclaimed its authority over the archipelago. The new Governor-General, G.A.G.Ph. van der Capellen, took over from his two predecessors the principles of direct rule and military control in Java. Instead of a decentralized system of commercial settlements and treaties with sovereign leaders, van der Capellen adopted a centralized administrative system and direct rule with control by appointed civil servants. At the same time the Binnenlands Bestuur (the Interior Administration) was complemented by an Inlands Bestuur (Indigenous Administration), symbolically profiled as 'older' and 'younger' brothers. The latter group consisted of regents who acted as civil servants and were part of the new bureaucracy. The choice for this system had to do with the conviction that the vast archipelago could not be controlled militarily and administratively by the small European community.

In contrast to the VOC-policy, the administration did not try to extend the system of commercial settlements during the $19^{\text {th }}$ century. In addition, no direct rule was effectuated for the Outer Provinces. For a large part of this century, the effective control remained restricted to Java, some settlements in the Moluccas, Banka (because of the tin) and Timor.

\footnotetext{
Zandvliet, Kees, De Nederlandse ontmoeting met Azië 1600-1950 (Amsterdam, Zwolle 2003) $31,293$.

Committee of East Indian Commerce and Possessions, Council of Asian Possessions and Establishments respectively.
} 
On the other islands, bases were established to control the hinterland: Padang and Palembang on Sumatra, Banjermasin, Pontianak and Sambas on Borneo and Makassar and Menado on Celebes. In 1860, only 1,200 Europeans were living outside Java and southern Sumatra. ${ }^{3}$

During most of the $19^{\text {th }}$ century the Dutch applied the principle that the colonies had to contribute to the treasury of the homeland. The so-called Cultuurstelsel was called into existence to make sure that these contributions were substantial and supported the Dutch state, which had become impoverished by the French occupation and by military campaigns. ${ }^{4}$ One of the important features of the 19th century in Java was the introduction of this Cultuurstelsel by Governor-General J. van den Bosch in 1830. After its implementation, the population was obliged to cultivate $6 \%$ of its agricultural area with products for the European market, such as coffee, tea, sugar, indigo and tobacco. The government set the price the indigenous farmers received, which was usually very low. The Nederlandse Handel Maatschappij (NHM, Netherlands Trade Company) took care of transportation and sale in Europe and acquired large profits. There was considerable criticism of extortion with this system.

From 1870, the Agricultural Law and the Sugar Law replaced the former system. These laws offered to private individuals (read: Dutch and foreign capitalists) the opportunity to hire or lease land and start plantations at their own account and risk. These new business opportunities attracted entrepreneurs and adventurers who started to cultivate crops that were attractive because of world market prices. Thus, at the East Coast of Sumatra tobacco estates were established and later also rubber plantations. On Java, many tea, coffee and sugar plantations had been started under the Cultuurstelsel. Little by little, private individuals or companies took over these plantations. According to Fasseur, a third post-VOC period started in 1870. He calls it a period of free labour and economic opening of Java and the Outer Islands for plantations and mining companies. ${ }^{5}$

The government felt that the policy of indirect rule in the Outer Provinces needed reassessment. This feeling was supported by threats from outside, where other countries kept an interest in the rich possibilities of the archipelago. After 1890, the principles of indirect administration and semi-autonomy of local princes were laid aside. Direct rule came in its place. The so-called Korte Verklaring (Short Contract), which had to be signed by local rulers, will be discussed in the next chapter.

3 Joop de Jong, De waaier van het fortuin, de Nederlanders in Azië en de Indonesische archipel 1595-1950 (Den Haag 2000$) 232$. Transl.: The wheel of fortune, the Dutch in Asia and in the Indonesian Archipelago 1595-1950

4 Cultuurstelsel (Cultivation System): a system of forced cultivation of crops for the European market.

5 C. Fasseur, "Nederland en Nederlands-Indië 1795-1914", in: Algemene Geschiedenis der Nederlanden XI (Bussum 1983) 348372. The first two ones being the years 1795-1830 (characterized as age of uncertainty) and 1830-1870, the Period of the Cultuurstelsel. 
In 1890, the number of Europeans living outside Java had grown to ten times the figure of 1860: 11,950 , but this increase took place mainly in the towns mentioned before. ${ }^{6}$ Regrettably, there are no reliable figures on the total population of the Outer Islands. In 1890, the total figure of the population of Java was 23.7 million, including 43,919 Europeans and 237,579 Chinese. ${ }^{7}$ An estimate of the population of the Outer Provinces by the same publication suggested a figure of 6.5 million inhabitants (figures for 1889).

\section{HEALTH POLICY IN THE $19^{\mathrm{TH}}$ CENTURY}

In the $19^{\text {th }}$ century, health care and hospitals in the Netherlands Indies followed economic activities and fitted in with new settlements of Europeans. At first, these hospitals settled where the military established new garrisons. After 1870, this occurred in places where groups of new entrepreneurs settled, such as the East Coast of Sumatra. In this new situation, the health facilities no longer remained reserved for European patients.

\section{General medical policy}

In the $19^{\text {th }}$ century, the public health policy of the Netherlands Indies Government regarding the civilian population was laid down in regulations that were published in the Staatsbladen (Statutebooks) and Bijbladen (Auxiliary Statutebooks). All of these regulations stressed the principle that the Civil Medical Service assumed no responsibility for individual hospital care, whether it be paid or supplied free of charge. In a supplementary regulation, issued by the Director of the Department of Onderwijs, Eeredienst en Nijverheid (Education, Worship and Industry $)^{8}$ it was stated that provisions would be made available only for the medical treatment of the pradjoerits (native policemen), syphilitic prostitutes, insane and badly wounded patients or other patients taken in by the police force.

Such a policy appeared to be no exception in colonial settings. In the case of British India, David Arnold stated: “The colonial power took a narrow view of its own responsibility for the health and welfare of the bulk of the Indian population and, until well into the second half of the nineteenth century, tried to restrict its financial and administrative commitments to those areas of immediate concern or inescapable involvement like the army and the jails." This author compared this attitude with Britain's own social history in which private philanthropy and public charity had played a major part, visible in the founding of hospitals, dispensaries and medical schools. However, it may be noted that governments such as the Dutch and British central government seldom embarked on initiatives in the field of individual health care. In both cases (British India and the NI) private initiatives, such as 
missionary hospitals, might be considered as the equivalent of the charitable initiatives in the home countries.

In the $20^{\text {th }}$ century, contrary to public policies at home, the NI government began to play a prominent role in collective as well as individual health care. Prior to that time, in the $19^{\text {th }}$ century, there were political principles and attitudes that influenced the establishment of hospitals in a negative way. For example, governments placed obstacles to missionary societies. Missionary hospitals often had a difficult start. Many Protestant zendelingen (missionaries), later Roman Catholic missionaries too, had difficulty in obtaining a license to settle in the archipelago during the $19^{\text {th }}$ century. The NI government wanted to avoid unrest with Muslim communities, as the settlement of missionaries could start disputes and disturbances. ${ }^{10}$ At first, there was no government subsidy for missionary activities. Still, a few substantial German and Swiss missionary activities made their entrance in the NI during the $19^{\text {th }}$ century. The Rheinische Mission from Wuppertal settled in the region of the Bataks in Northern Sumatra in 1861. The Neukirchener Glaubensmission settled in Salatiga on Java in 1884. Later, the German catholic community Societas Verbi Divini (Society of the Divine Word) settled on Flores (1913). The government remained very cautious, especially where conflicts could easily rise. If imminent danger was expected, the missionary's access to the region in question could be withdrawn and the missionary given an assignment to another area.

In addition to the negative attitude of government officials during a great part of the $19^{\text {th }}$ century, the heads of religious or missionary organizations were not enthusiastic about missionaries taking on medical services. They pointed out that the main task of the missionary was preaching the gospel and converting the indigenous population. All additional tasks were considered to be secondary. ${ }^{11}$ Nevertheless, the population and authorities knew that some missionaries were interested in and cared for other needs than religious education only. In fact, the distribution of medicines among missionaries was promoted by the authorities and this often led to more missionary medical work. Some missionaries received training in medical assistance by some hospitals and a few even completed medical training. ${ }^{12}$ In chapter 4 it will become clear that only from about 1890 the political restrictions on religious activities were loosened. From then on, many missionary hospitals were established, mostly on Java and in the Moluccas.

10 Kappelhof makes a distinction in 3 periods: 1798-1900, 1900-1942 and the post-war period. From 1800, in the French period, freedom of religion was announced, and a large number of missionary associations and congregations were called into existence. They were not easily accepted in some regions of the NI, not before 1850 .

11 De Nederlandse Zendingsvereniging in West-Java 1858-1963, een bronnenpublicatie, Th. Van den End ed. (Oegstgeest 1991). De Gereformeerde zending in Midden-Java 1859-1931, een bronnenpublicatie, H. Reenders, ed. (Zoetermeer 2001).

12 One of these doctors was S. Pruys. 


\section{Medical science and training}

On 4 July 1808, there were issued the Regulations of the Medical Services with the King's Army in the Possessions of the East Indies. These Services were entrusted to health officers with the ranks of $1^{\text {st }}, 2^{\text {nd }}$ and $3^{\text {rd }}$ class and the titles of chirurgijn majoor, aide chirurgijn and élève chirurgijn. ${ }^{13}$ The Regulations had been designed by the chief surgeon J. Heppener, one of the students of S.J.Brugmans. ${ }^{14}$ In the next decennia, it became clear that the actual number of health officers did not correspond with the number needed. ${ }^{15}$ Actions to solve this problem were not always met with enthusiasm as the following example illustrates. In 1847, the Chief of medical services, W. Bosch, (1845-1853) expressed his concern about the health situation of the Javanese population, while a severe epidemic had taken place in Central Java that caused considerable misery and thousands of deaths. ${ }^{16}$ Bosch proposed a number of measures, including temporary facilities to treat patients, offering them financial aid, but also by setting up a training for auxiliary doctors. His proposals were ill received, because he implicitly criticized the Cultuurstelsel as being the cause of people's misery and impoverishment. Schoute mentions correspondence between Batavia and The Hague and a sizeable personnel file, in which Bosch was called the enemy of the government. ${ }^{17}$ Thanks to the mediation of Governor-General J.J. Rochussen (1845 - 1851), Bosch was retained in his job and was given the opportunity to start a school for indigenous doctors in $1851 .{ }^{18}$ The other proposals of Bosch were rejected, which was understandable, as we saw that the government did not have the intention to become engaged in individual health care. The start of the school for indigenous dokters was only supported because the decision makers (Governor-General and Council of the Indies) assumed that Bosch was going to train vaccinators. Nevertheless, Bosch managed also to get approval to start a school for midwives in the same year. There had been an earlier initiative to train native midwives, during the Daendels regime in the beginning of the century. At that time, town doctors gave obstetric lectures to indigenous women in order to replace the doekoens baji. ${ }^{19}$ Regrettably, this had not been successful and neither was the new attempt of June 1851, in which 20 pupils were admitted to the midwifery school. By 1875 it was even decided to close this school. It was not the training itself that failed, but the population did not ask the graduated midwives to assist at childbirth. Pregnant women preferred the female doekoens. As the Resident of the Preanger Regencies reported in 1860: They perceived the educated

\footnotetext{
13 Surgeon major, assistant surgeon and student surgeon.

14 S.J. Brugmans (1763-1819) was director of the Geneeskundig Bureau der Bataafsche Republiek. From 1795 he organized the military medical services and started a training for medical practicians at Leiden (1763-1819).

15 Schoute, "De Geneeskunde in Nederlandsch-Indië", GTNI 74 (1934) 16, 1009-1022.

16 W. Bosch signed with the title: Chef over de Geneeskundige dienst in Nederlandsch Indië.

17 Schoute, "De Geneeskunde in NI", GTNI 75 (1935) 8, 666-667.

18 The officer of health, P. Bleeker, was the first director of the school (1851-1860).

19 Doekoen is an indigenous healer. The doekoen baji is an indigenous midwife.
} 
midwives as a danger to their marriage, for it sometime happened that the husband left his wife to marry the more civilized midwife, to enhance his status. ${ }^{20}$ Like this unsuccessful effort to improve professional health care training, the training of native dokters suffered from the beginning from quality and status problems. Contrary to the midwives, by the end of the century, and following the necessary adjustments to the curriculum, the dokter djawa became a widely accepted professional, who had a substantial share in the care of patients. ${ }^{21}$ By 1890, the number of dokters djawa came near to that of the European (military and civilian) physicians: 108 dokters djawa on 143 European physicians. This increase in physicians was offset by the much greater increase of the population to about 32 million inhabitants, with a ratio of 1 physician/dokter djawa per 125,000 people.

In 1851, at about the same time as the start of the noted medical training, an association was founded to study medical science in the Netherlands Indies: De Vereniging tot bevordering der geneeskundige wetenschappen in NI (The Association to promote medical science in the NI). In 1853 this association decided to issue a journal, the Geneeskundig Tijdschrift voor Nederlands-Indië (Medical Journal of NI) in which medical practitioners published their findings on patients they had treated and discussed matters of common interest. ${ }^{22}$ On regular occasions the Vereeniging organized well-visited scientific meetings, during which one or two members held a lecture, which was published in the Medical Journal. Debates took place concerning subjects such as the causal agents of cholera that could be detected in water and the acquisition and conservation of anti-diphtheria serum in the NI. The European metabolism in the tropics proved to be a very popular subject. ${ }^{23}$ In the field of science, the Bataviaasch Genootschap van Kunsten en wetenschappen (Batavian Society of Arts and Sciences) was accompanied by the Natuurkundige Vereeniging (Society of Natural Sciences) in 1850. One of its initiators and members was P. Bleeker, the first director of the Dokter Djawa school, who took an interest in the ichthyology and published an atlas on fishes in Indonesian waters. ${ }^{24}$ The health officer, G. Wassink, who succeeded W. Bosch as chief of the medical services (1853-1864), was interested in the effects of traditional Indonesian medical herbs and initiated a Hortus Medicus in the famous Plantentuin of Buitenzorg in $1850 .{ }^{25}$ This Plantentuin had been initiated in 1817 by the newly appointed Director of Agriculture, Arts and Science, C.G.C. Reinwardt. ${ }^{26}$ Wassink stimulated the research on traditional medical herbs throughout the country and published

20 Schoute,"De Geneeskunde in Nederlandsch-Indië", GTNI, part 75 (1935)8, 670.

21 Liesbeth Hesselink, Healers on the colonial market. A thorough study on native doctors and midwives in the Dutch East Indies.

22 This journal started in 1853 and published its last articles in 1942.

23 A. de Knecht- van Eekelen, "The interaction of Western and Tropical medicine", in: A.M. Luyendijk-Elshout (ed.), Dutch Medicine in the Malay Archipelago (Amsterdam 1989) 57-71.

24 P. Bleeker, Atlas ichthyologique des Indes orientales (s.l, s.a.).

25 Theo F. Rijnberg, 's Lands Plantentuin, Buitenzorg 1817-1992 (Enschede 1992).

26 So far, it did not receive much historical attention. Nowadays, it still functions under the name Kebun Raya Indonesia Bogor. 
a series of articles in the Geneeskundig Tijdschrift: On research into the therapeutic properties of indigenous medicines.

It was J. K Hasskarl, former director of the Plantentuin, who obtained in 1855 quinine plant seeds from its native country, Bolivia. The German doctor and scientist F.W. Junghuhn, a friend of Hasskarl, cultivated the plants and from 1865 the cultivation took place on a large scale in the Bandoeng area. Eventually, it would become a booming business and the Bandoengsche Kinine Fabriek, dating from 1896, managed to supply more than $90 \%$ of the world quinine demand in the period prior to World War II. The NI population could obtain large quantities of the Bandoeng pill for low prices. During malaria epidemics, quinine was distributed without cost. ${ }^{27}$

During the last decades of the $19^{\text {th }}$ century, beriberi became a serious problem in military camps, some prisons, camps for convicts and in the coolies' living quarters. Many died and there was considerable suffering. As the cause of this disease was unknown, no useful therapy could be developed. Therefore, in 1887, the Dutch government sent two scientists, C.A. Pekelharing and C. Winkler, for an enquiry into the nature and causes of beriberi. ${ }^{28}$ Ultimately, this became the start of the Laboratory for Pathological Anatomy and Bacteriology at Weltevreden. In order to facilitate the work of the Dutch scientists, this laboratory was set up in the military hospital at Weltevreden. Eventually, it would become the renowned Eijkman-Institute.

\section{ORGANIZATION OF MEDICINE}

Medicine in the Netherlands Indies during the French epoch and in particular during the period of Marshall H.W. Daendels (1808-1811) depended on the military. Soon after Daendels started to organize military medicine, a significant change took place in the quality of surgeons. Well-educated military surgeons were engaged in the new military hospitals. They were called "health officers" and had passed the newly started training for medical practitioners developed by S.J. Brugmans in Leiden. Some had passed examinations in the NI that corresponded to the programme in Leiden..$^{29}$ Daendels reorganized the health service, founded three large military hospitals on Java and closed the City Hospital. The military hospitals were established at Weltevreden (on the outskirts of Batavia), at Semarang (Central Java), making use of and extending the new Company's hospital, and at Soerabaja (East Java), by building a new one on the bank of the river, the hospital at Simpang. ${ }^{30}$ Although Daendels ruled only for three years, he strongly influenced developments of health care. The significance of Daendels in the field of medicine was not restricted to the

27 www. sinkona/indonesia.com, page 191, accessed 27th October 2015, 13:00.

28 Koloniaal Verslag 1887, 105-106.

29 Schoute, Occidental Therapeutics, 99.

30 Donated by Johan Siberg, see note 55, page 37. 
founding of well-equipped military hospitals, but also to the way he met the unhealthy situation in Batavia. Many buildings in the old town, including the old castle and the old City Hospital, were demolished and people were invited to abandon the unhealthy surroundings and move to Weltevreden.

After his departure and the British occupation of Java in 1811, Lieutenant-Governor Th. S. Raffles (1811-1815) took over. Raffles had little interest in military medicine. He appointed the Superintendent Surgeon Doctor William Hunter, who mainly occupied himself with the civilian side of medicine. During his equally short regime Raffles greatly improved smallpox vaccination and took measures to check the population for venereal diseases.

Returning to the Dutch rule in 1816, a dual system was chosen. The newly appointed Director of Agriculture, Arts and Science, the Utrecht professor C.G.C. Reinwardt (18161822), drafted extensive regulations for the Civil Medical Service, which were introduced in April 1820. In the same year, new regulations were issued to reorganize the vaccination against smallpox. ${ }^{31}$ Three inspectors were appointed: the surgeon J. Bowier for the Military Medical Service, C.G.C. Reinwardt for the Civil Medical Service and the civilian doctor C.L. Blume for the Vaccination Service. ${ }^{32}$ About seven years later, this dual system was abandoned and both the medical services were joined under one chief, the chief of the Military Medical Service. ${ }^{33}$

To position in historical perspective the different branches of health care (military and civil), it is useful to compare the $19^{\text {th }}$ century with the VOC situation. Until 1800 , medicine in the VOC settlements focused on the European population. There was hardly any hospital capacity available for the indigenous population. In contrast, ample means were available for the civil (European) hospitals at Batavia and in the Moluccas. There were no separate military hospitals. The situation changed after 1800, under the Daendels administration, when many new military hospitals were established. A period of blooming military hospitals and deteriorating civil hospitals started and continued until the end of the $19^{\text {th }}$ century.

The focus on European civilians during the first two centuries and on the military during the $19^{\text {th }}$ century resulted from the way in which medical interests were organized. At first, ships chirurgijns were recruited from civil ranks and the functions of the colonial administration were all held by civilians. From 1827, during the greater part of the $19^{\text {th }}$ century, the military took over and brought the Civil Medical Service under command of the chief of the Military Medical Service. In 1882, the Civil Medical Service became a division of the Department of Education, Worship and Industry (EWI). The director of this department became the formal head of the CMS. A certain degree of unity was

31 Reglement op de uitoefening der koepokinenting in Nederlandsch-Indië (Regulations on vaccination in NI).

32 Schoute, "De geneeskunde in N.I.", GTNI 74 (1934)18,1167.

33 From 1827 the supervision ("Toevoorzigt") of the civil medical service was transferred from the government commissioner to the chief of the military medical service. 
maintained, for the chief of the MMS was chief of the CMS at the same time. In the latter capacity, however, he was accountable to the Director of the Department of EWI. ${ }^{34}$

The functioning of the Civil Medical Service as a division of the Department of Education, Worship and Industry created a difficult organizational structure. It could be predicted that this construction would eventually lead to a final separation of both services. However, this separation would only occur 29 years later, in 1911. The regulations of 1882 followed Dutch legislation, dating from 1865, in which the medical training and profession acquired a uniform statute. In the NI, regulations were issued for a Geneeskundig Staatstoezicht (Medical Inspection) and conditions for the right to practice medicine, dentistry, obstetrics and pharmacy. ${ }^{35}$

\section{VACCINATION}

In the year 1803 a significant medical substance was taken to Java. After a journey from India to Isle de France and from there to the East Indies, 'vaccine' arrived at Batavia. Unfortunately, the vaccine against smallpox proved to be ineffective due to the long seavoyage. The NI Government then sent a vessel back to the Isle de France with 10 or 12 children aboard under supervision of the military doctor M. Gauffre. The precious article had to be kept 'alive' during the long sea-journey by inoculation from child to child. ${ }^{36}$ From its arrival a campaign started against what was called the scourge of the East-Indies: smallpox. Whereas few health care programmes in the colony proved to be effective, this one ultimately appeared to be. After a number of problems and failures, the number of children affected by smallpox decreased and this may be considered one of the reasons for the large population growth on Java, especially during the second half of the century. ${ }^{37}$ Quite an army of vaccinators was mobilized, starting with local priests, who usually succeeded to make the population co-operate. Sometimes they even succeeded in receiving parents' consent to send their children around the archipelago to keep the vaccine alive in the same way as during the initial voyage. The priests were followed up by doekoens, indigenous schoolmasters, and missionaries. Finally, dokters djawa were assigned to train professional vaccinators.

The first initiative to introduce smallpox vaccination into the Netherlands Indies had been from Dr. Laborde, French medical chief of Reunion and Isle de France. Lieutenant Governor Raffles continued and extended the vaccination program on Java. But after his departure, there was stagnation for some decennia. Possibly and partly because of opposition from the population. Sometimes resistance was met, with the arrival of a vaccination team in a

\footnotetext{
34 The department is often referred to as department OEN (Onderwijs, Eeredienst en Nijverheid).

35 Staatsblad no. 97 of 20 April 1882, "Reglement op de burgerlijke geneeskundige dienst" (Regulations of the Civil Medical Service).

36 D. Schoute recorded a very detailed story in: Occidental Therapeutics, $93-98$.

37 P. Boomgaard, Children of the Colonial state: population growth and economic development in Java, 1795-1880 (Amsterdam 1987).
} 
village and children were held back. Parents had often heard rumours, sometimes from their religious leaders, about the spell that came upon their children after these underwent the vaccination.

In 1856, the newly appointed Inspector of vaccination, A.E. Wasklewicz, divided Java into circles, the so-called straalsysteem (Circle or radius-system), intended to minimize the distance people had to walk to an inoculation centre. The longest distance was five paal $(7.5 \mathrm{~km}) .{ }^{38}$ From then on, the number of vaccinations and of re-vaccinations grew as shown in Table 1. In 1879 a national vaccination institute, Parc Vaccinogène, was established in the Residency of Buitenzorg. In its programme were the production of vaccine and the training of vaccinators. Starting with an annual budget of $f 2,103$ this institution expanded and became a powerful institute. The introduction of the straal-systeem together with the improvement of the service and the foundation of the Parc Vaccinogène became the foundation of an effective fight against this public enemy, which accounted for a $10 \%$ death-toll at the beginning of the century. ${ }^{39}$

Table 1 Vaccinations on Java and Madoera 1860 to 1890

\begin{tabular}{lccc}
\hline Year & Vaccinations & Revaccinations & Total \\
\hline 1860 & 479,768 & 211,051 & 690,819 \\
1871 & 524,553 & 209,479 & 734,032 \\
1875 & 570,652 & 360,201 & 930,853 \\
1889 & 644,043 & 444,338 & $1,088,381$ \\
\hline
\end{tabular}

Source: KV 1890, 126 and Schoute GTNI, part 75 (1935) 9, 736.

If we compare the course of events in the field of inoculation (variolation and vaccination) against smallpox, we can determine that in The Netherlands, the variolatie (inoculation with smallpox virus) had been used from about 1750 and became more or less obligatory for the poor and rural people from 1801. In that year, the French Executive Administration decided on general introduction of inoculation with kinderpokstof (variola). In 1808, King Louis Napoleon required minvermogenden (poor people) to have their children vaccinated. ${ }^{40}$ In 1823, the anti-smallpox measures were extended to children who attended school. They had to show their pokkenbriefje (Pox certificate) before being admitted to school. Due to pressure from Protestant Christian organizations, the obligatory Pox certificate was revoked in 1857. In the next decennia, this pattern of events was repeated: requirement and rescinding of the obligation, until in the period 1871-1873 about 23,000 people had died of smallpox in The Netherlands.

38 P. Peverelli, De zorg voor de Volksgezondheid, 52-53.

39 See for extensive reports: Schoute, "De Geneeskunde in NI “, GTNI, part 74 (1934) 15, 944-950.

40 E.S. Houwaart, De hygienisten, Artsen, staat \& volksgezondheid in Nederland 1840-1890 (Groningen 1991) 30-31. 
The Law on Contagious Diseases of 1872 introduced once more the pokkenbriefje. ${ }^{41}$

\section{PUBLIC HYGIENE}

In the middle of the $19^{\text {th }}$ century a debate took place in the homeland about the influence government and medical establishment should exercise on the circumstances of life of the population. Committees were installed to supervise the medical condition and hygiene of towns, regions and provinces. In order to assess conditions of life and housing of the population, the medical committees felt it necessary to describe these circumstances. Quite a number of these descriptions were composed and covered various subjects, such as the local weather over periods of time and for each month, the quality of the soil, the quality of school-buildings, houses, hospitals, etc. These geneeskundige plaatsbeschrijvingen (medical topographies) offered a source of information upon which appropriate measures could be taken. Beside these descriptions, considerable value was attached to statistics about demography, health conditions, occurrence of diseases, costs of living, number of patients and similar matters. In the 1870s and 1880s, authorities (medical and political) took measures in the field of water-supply, of buildings and of pollution. ${ }^{42}$ In the wake of these developments, similar impulses took place in the colonies abroad.

From around 1850, health officers systematically gathered and published statistics and composed geneeskundige plaatsbeschrijvingen. These publications were organized by the "Vereeniging tot Bevordering der Geneeskundige Wetenschappen in Nederlandsch-Indië "(Association to promote medical science in the NI). This Association issued a magazine with case studies, annual reports, statistics and professional news. As mentioned before, this magazine, the Geneeskundig Tijdschrift voor Nederlandsch-Indië, provided a rich source to study developments in the field of medical research, professional and institutional achievements and health care in the Netherlands Indies. In this context, Boomgaard mentions two medical doctors: W. Bosch and P. Bleeker, who both made important contributions to the development of medical science and medical education. ${ }^{43}$

Half a century later, when the independent Civil Medical Service was formed, the official tasks of this service became among others: Improving sanitation of towns, housing, supply of water, sewerage, removal of faeces, fighting endemic diseases and statistics. ${ }^{44}$

\section{METAMORPHOSIS OF HOSPITALS}

During the VOC period, hospitals were business institutions and not charitable ones. Hospitals were founded and exploited by the VOC and not by the military. During the $19^{\text {th }}$

41 Houwaart, De hygiënisten, 37, 268-271.

42 Ibidem, 176 and 188.

43 Peter Boomgaard, “The making and unmaking of tropical science, Dutch research on Indonesia, 1600-2000", Bijdragen tot de Taal-, Land en Volkenkunde (BKI)162 (2006) 200-202.

44 Peverelli, De zorg voor de Volksgezondheid in Nederlandsch-Indië, (The Hague, s.a.). 
century, roles would change and the military took over. But before discussing the developments of this century in the Netherlands Indies it may be useful for comparison to look at hospital developments elsewhere in the world.

In the Western hemisphere, changes took place that brought about a metamorphosis of the hospital scene. These changes occurred under influence of far reaching reforms in the hospital world, which started in the course of the $18^{\text {th }}$ century, particularly in Britain, France, Germany and Austria/Hungary. In Great Britain it started with the "Hospital movement" which developed in two stages. The first stage showed the rise of a new type of hospital architecture that replaced the existing hofbouw design (court yard architecture) by a structure, called the 'corridor-system'. ${ }^{45}$ In the second stage health policy combined two tendencies: the tradition of founding and running hospitals for the poor and homeless, together with the efforts to combat diseases. The resulting discussions led to the renaming of alms-houses into hospitals. These hospitals became institutions that focused the attention on curable patients or patients who were considered suitable for medical interventions. ${ }^{46}$ Houwaart explains that until the mid $-19^{\text {th }}$ century the corridor hospital with its social structure was the dominant form of the English institutional hospital care.

Whilst in England only few innovations took place in the first decades of the $19^{\text {th }}$ century, the developments in France around 1800 led to the rise of the modern medical practice. M. Foucault analysed the relation between medical knowledge and medical potencies. ${ }^{47} \mathrm{He}$ suggested that in the hospitals of Paris the hospital bed became a social system. This system no longer concentrated on individual cases, but was more interested in the system of diseases and its ranking. The patient became an object instead of an individual. The doctor disposed of knowledge and henceforth the patient was considered to be ignorant and inexpert. Changes in French medicine about 1800 generated the image of the hospital as a place of technical innovation. The rise of experimental research, reforms of medical education and changes in the doctor-patient relationship were identified to be a result of medico-political changes at the time of the French revolution.

Critics have it that this French system only applied to a few city hospitals, especially Paris hospitals. The remaining hospitals carried on to be almshouses in which hardly any medical innovation took place. Roy Porter tones down the Paris medicine by remarking: 'though these shifts in medical outlook were momentous, their abruptness should not be exaggerated.' And further: 'Paris fashions, as always, made the world stare, and the new model of a science of diseases enjoyed remarkable sway.' ${ }^{48}$

45 For the hofbouw design, see the example of the Colombo hospital, fig. 1

46 Houwaart, De ontwikkeling van het ziekenhuis in de moderne tijd,239-244 and 263.

47 M. Foucault, La naissance de la clinique (1963).

48 Roy Porter, The greatest benefit to mankind, 307. 
Yet, this so-called French School influenced the ideas in the Anglo-Saxon literature. In France, but also in Great Britain the clinical medicine resulted in the establishment of specialized hospitals that were the first real medico-curative institutions, whereas at the same time the main hospitals for the poor continued to exist. For the United States of America, Rosenberg situates the principal development of America's hospital system in the period 1870 to $1920 .^{49}$ Not long before, after the Civil war ended, a general hospital had been a primitive institution supported by the philanthropy of the wealthy. However, by 1900 the hospital had not only spread widely in the United States, but it had become a potential recourse for a much larger proportion of Americans. In the words of the author: 'the prosperous and respectable as well as the indigent were now treated in hospitals.' New disease concepts, therapeutics, diagnostic tests and surgical procedures justified the hospital's newly prominent role in medical care. Morris J. Vogel, an other American author speaks of 'the invention of the modern hospital,' and describes the development of Boston's hospitals in the decennia between 1870 and 1920. He emphasizes that above all social and economic factors contributed to transform charity hospitals into modern scientific institutions for all social classes. As for The Netherlands, the rise of this hospital system may be placed likewise in the period 1870 to 1920 . The Coolsingel Hospital at Rotterdam became one of the first modern hospitals, soon to be followed by others in the main Dutch cities. The Gasthuizen gradually disappeared.

In the meantime, the ideal hospital architecture had changed fundamentally, especially in Germany and Austria. In The Netherlands, the corridor system made way for the pavilion structure in the last quarter of the century. The need to isolate patients in view of epidemics caused a rejection of the corridor system. In Amsterdam the Wilhelmina Gasthuis and the Onze Lieve Vrouwe Gasthuis were examples of this new hospital architecture. In the Netherlands Indies similar discussions took place. The need for fresh air for the patients, of isolation when necessary and of separation of groups of patients, called for a system with pavilions that were mutually connected with covered gangways. One of the first examples was the psychiatric hospital at Buitenzorg, which will be discussed later. The pavilion system proved to be ideal for the Tropics, but too expensive and impractical in the context of densely populated cities in Europe with high prices for building sites.

\section{FROM VOC HOSPITALS TO MILITARY HOSPITALS}

The first years after the end of the VOC era, health care had the same characteristics as before: corresponding with hospital care, executed mainly by chirurgijns and available mainly for European patients. As far as the medical aspect is concerned, the situation improved. At Batavia, the high number of hospital admissions and mortality belonged to

49 Rosenberg, The Care of Strangers. 
the past. Schoute mentions the year 1806, when 2,540 patients were admitted to the Outer City Hospital. During that year 2,175 patients were dismissed as recovered and 192 died. Still, the situation in the old town had not improved, it was as unhealthy as before and people decided to leave and move towards southern settlements, such as Weltevreden.

As for the employment of surgeons and other hospital employees, some of the former VOC employees received a military assignment and some of them became civil servants. Actually, a growing number of surgeons chose private practice or was appointed as city surgeon or hospital surgeon. Although information on exact numbers and percentages is missing, we may acquire an indication by looking at a list of 1802. On this list were names of all the surgeons (57), who were employed in Batavia and its immediate surroundings. The ratio between civil and military service was approximately 50:50. There were 28 surgeons in the civil service and 29 in military service. ${ }^{50}$

The regulations for health care remained much the same until Governor-General H.W. Daendels arrived. The reforms by Daendels, described earlier, marked the hospital developments for a number of decades. During almost the entire $19^{\text {th }}$ century, health care in the Netherlands Indies was dominated by the military. By the end of the $19^{\text {th }}$ century, in the year 1880, 186 doctors (surgeons and medical doctors) were on the military pay-roll, compared to 84 working in a civil setting, either as private physicians (36) or employed by the civil administration (48). The ratio (military: civilian) had shifted to 70:30.51

This meant for the hospitals that the military hospitals began to play a dominant role. Their significance went beyond the contemporary civil hospitals that after VOC era deteriorated and became less important: the facilities decayed and the available budgets progressively diminished. In the course of the century, quite a number of military hospitals, garrison hospitals and infirmaries were added. Schoute reproduces a survey for 1867 edited according to the instruction of the Dutch government (see Table 2). ${ }^{52}$

Table 2 Military hospitals in 1867

\begin{tabular}{lcccccc}
\hline \multirow{2}{*}{ Kind of hospital } & \multicolumn{2}{c}{ Java } & \multicolumn{2}{c}{ Outer Provinces } & \multicolumn{2}{c}{ Total } \\
\cline { 2 - 7 } & Number & $\begin{array}{l}\text { Beds } \\
\text { occupied }\end{array}$ & Number & $\begin{array}{l}\text { Beds } \\
\text { Occupied }\end{array}$ & Number & $\begin{array}{l}\text { Beds } \\
\text { Occupied }\end{array}$ \\
\hline Military Hospital & 3 & 1601 & & & 3 & 1601 \\
Garrison Hospital & 14 & 1052 & 21 & 1197 & 35 & 2249 \\
Infirmary & 8 & 64 & 33 & 285 & 41 & 349 \\
\hline Total & $\mathbf{2 5}$ & $\mathbf{2 7 1 7}$ & $\mathbf{5 4}$ & $\mathbf{1 4 8 2}$ & $\mathbf{7 9}$ & $\mathbf{4 1 9 9}$ \\
\hline
\end{tabular}

Source: Schoute, GTNI 75 (1935) 825-828.

50 Schoute, Occidental therapeutics, 92.

51 S. Zondervan, De ziekenhuizen van Nederlands Oost-Indië in de negentiende eeuw (Paper Master Medical History Vrije Universiteit, Amsterdam 2005) 18.

52 Schoute, "De Geneeskunde in NI", GTNI 75 (1935) 825-828. 
Annually on average, 50,000 to 60,000 patients were treated in the military hospitals. Some of these patients came from the civilian population, but most of them were soldiers. Nursing and treatment were provided for patients suffering from venereal diseases, fevers (malaria), beriberi, ulcers and from fractures and wounds incurred on the battlefield. Concerning the provision of food and medicine to the patients in the hospitals: Daendels abolished the fraudulent outsourcing system by which the hospital manager received an allowance for these materials. Henceforth, the bills were paid directly. New was the regulation about a filing system of all inpatients concerning the diseases treated.

The character of the hospitals in the large cities on Java changed drastically. Some civil hospitals were turned into military hospitals, in which soldiers and sailors were given preference, while civilians could be admitted only if accommodation was available. Another considerable change in the regulations concerned the admittance of indigenous patients into the same hospital as Europeans, though separated from each other. ${ }^{53}$

\section{Public general hospitals}

As for the general hospitals that provided health care for civilians during the $19^{\text {th }}$ century, they are divided into three rather small groups.

- The old hospitals, dating from the VOC period. Only two remained: The City Hospital and the Outer City Hospital

- The so-called Stadsverbanden (City Dressing Stations)

- The Inlandsche hospitals in the countryside, hospitals for the indigenous population.

\section{The City Hospital}

As mentioned before, the City Hospital in Batavia had been founded during the VOC era. This hospital suffered from a bad reputation because of its high mortality rate. Daendels decided (Decision of 4 April 1808) to close this hospital. ${ }^{54}$ In 1830 the premises and buildings were bought by the "Java'sche Bank", that established its headquarters on that location.

\section{The Outer City Hospital (Buitenhospitaal)}

In 1808 laboratory, pharmacy and patients were removed from the City Hospital to the Outer City Hospital, that acquired a larger capacity but did not gain a more important role in health care. In its place, the nearby Military hospital at Weltevreden grew significantly over the next decades. In 1836, Governor-General D.J. de Eerens (1836-1840) decided to close the Outer City Hospital.

53 Schoute, Occidental therapeutics, 100.

54 Nederlandsch-Indisch Plakaatboek, 1602-1811, XVII, 3184 (Batavia 1900). 


\section{Stadsverbanden (City Dressing Stations)}

After the City Hospital was closed, another civil hospital inside the old town was needed. The "wounded, crippled natives and Chinese, victims of revenge and rapacity, murderous attacks and by accidents ending up in such a state" had till then no other place than the prison and the Poor House for a shelter. The Resident of Batavia, van Lawick van Pabst, applied for a small provision like a Stadsverband (City Dressing Station) that before had existed inside the City Hospital. Together with the city surgeon, the Director civil buildings and the city doctor a plan was designed. For the small amount of $f 895,12$ one of the barracks of the old Powder mills was rebuilt and on 20 September 1819 this became the City Dressing Station. For reasons of economy an indigenous mandoer (supervisor) was charged with the supervision, later on to be replaced by a retired European soldier. The equipment was restricted to 30 mats, 30 leather pillows, 12 tin goblets, 6 spittoons, 20 food troughs, one set of instruments for amputation, one trepan, 1 box of scalpels, 12 surgical needles, 6 lancets and 2 stretchers to carry the sick or wounded. Schoute reports that thus was the simple start of an institution that a century later was to become the Centrale Burgerlijke Ziekeninrichting (Central Civil Hospital) of the Netherlands Indies. ${ }^{55} \mathrm{~A}$ renovation took place in 1842, after which the Stadsverband could admit 75 to 100 patients in four ample airy wards. The new building also housed a doctor's room and a room for autopsy. During an inspection in 1842, there were 48 female and 15 male patients. In a separate ward women were admitted with venereal diseases.

Two more City Dressing Stations were established on Java, at Semarang and Soerabaja. At Semarang, a small hospital had been established around 1850. The old and large one from the time of the VOC was transformed into a military hospital by Daendels. The new civil hospital was achieved by joining 5 small rooms of the old prison. In 1842, the medical doctor W. Bosch, the later chief of the medical service, found that the wards bore more or less the appearance of a hospital, but the building materials and the construction lacked quality and there were substantial problems in functioning. The number of patients at the time of inspection was: 93 males, 29 females and 18 abandoned children. The way these patients were treated was termed defective. Besides, means were lacking for nourishment, linen and cleaning. The Resident, who visited the hospital in 1865 , called it too small to be able to cope sufficiently with the growing number of patients. ${ }^{56}$ The number of admissions in that year was: 766 males (of whom 262 died), 495 females (74 died) and 23 children (7 died). Following another inspection, the two city-doctors were discharged, because of neglect: they never visited the hospital and the sick women were looked after by only one servant and were checked a few times a week by a dokter djawa. There was hardly any

55 Schoute, “De Geneeskunde in NI”, GTNI 74 (1934) 1168-1169.

56 A Resident was the highest European civil servant after the Governor-General. He was responsible for the administration of a Residency, a major civil district on Java or the Outer Provinces 
provision for nourishment and the patients received only rags to cover themselves. The same applies to the City Dressing Station in Soerabaja. In an inspection report in 1828, a kind of City Dressing Station was visited that was located inside one of the prisons. The city physician took care of both prisons: The Binnen-Boeyen and the Buiten-Boeyen. At the same time, he cared for the hospital for syphilitic women and the institution for beggars. The Women's Hospital had been founded in 1820, but was demolished in 1845. During an inspection in 1851, the chief of the Civil Medical Service judged negatively the City Dressing Station. Apparently, in the meantime a new building had been designated to house the sick of the population, the convicts and the syphilitic women. At the time, there were 20 indigenous patients, 60 kettinggangers (convicts) and 60 sick prostitutes. The hospital effectuated some improvements and extensions in the years 1851 and 1852.

\section{Indigenous Hospitals}

In the $19^{\text {th }}$ century, only a few reports are available about these hospitals. In 1879 , the NI Government officially recognized at least 4 hospitals for the local population: at Pasoeroean, Probolinggo, Wonosobo and Gombong. These hospitals acquired recognition and approval by the authorities, meaning that their employees were appointed by the NI Government. Concerning the remaining, unrecognized indigenous hospitals, we may conjecture that they originated from local initiatives, sometimes by local doctors (mostly health officers) and by dokters djawa who started some kind of provisional consultation room, outpatient clinic or primitive hospital. Sometimes, the local population took initiatives, but this seldom happened, as there was no urgent need for Western health care.

Table 3 Indigenous Hospitals 1877

\begin{tabular}{lcc}
\hline Region & General & Syphilitic \\
\hline West Java & 9 & 3 \\
Central Java & 5 & 3 \\
East Java & 9 & 6 \\
\hline Total & $\mathbf{2 3}$ & $\mathbf{1 2}$ \\
\hline
\end{tabular}

Source: Schoute, GTNI 75 (1935) 828-833

A report by the Director of Public Works regarding the hospitals that took care of sick inlanders was published in 1877 and was summarized by Schoute (see Table 3). ${ }^{57}$ All information taken together, the 1877 report calculated 35 hospitals for the civil population, including facilities for syphilitic prostitutes. In addition, there were 12 sick-bays in prisons (6 on Java, 6 on the Outer Islands) and 25 military hospitals (12 on Java and 13 on the Outer

57 Schoute, "De Geneeskunde in NI" GTNI 75 (1935) 828-833. The name of the director was not mentioned. 
Islands), which admitted indigenous patients. L. Hesselink, reporting about 1900, mentions 59 native hospitals on Java. ${ }^{58}$ The Koloniaal Verslag (Colonial Report) of 1902 notes for Java and the Outer Islands together a figure of $88 .{ }^{59}$ The varying numbers result from definition issues. The medical authorities and the local civil servants were not always able to tell, whether a hospital was an inlandsch hospital or a hospital for syphilitische vrouwen, or a combination of both or a combination with a local prison facility.

In 1879 , the government restated its position that it had no obligations in the field of health care towards the indigenous population and commented that only a few hospitals for indigenous patients and syphilitic patients should be combined to receive government recognition. Nevertheless, the number of recognized indigenous hospitals was on the move, as may be concluded from publications in the Koloniale Verslagen (KV) and in the Staatsblad (Statutebook). The KV 1879 mentions a practice of nursing of syphilitic patients and other free individuals in prisons. At the same time, attention was drawn to the fact that in many hospitals for sick prostitutes, other individuals were admitted. Apparently, this happened in such a way that these hospitals became general hospitals for indigenous patients. After repeating the official view that the government would take no responsibility for health care for civilians, an opening was offered by announcing a consultation of the Heads of Regional Administrations concerning the foundation of separate institutions, replacing the contested provisions. Under the influence of stimulating subsidies or upgrading to government status, some of these indigenous hospitals were able to deliver valuable contributions to the health care of the population.

\section{Private General Hospitals}

The phenomenon of private hospitals was already known of in the VOC period, as the Boedelmeesters (judicial executors of Chinese inheritances) and the Batavia Deacons built hospitals, which were owned by private foundations or associations. Judicially, these hospitals had a private status, in contrast to the hospitals mentioned before, which had a public status. The main difference between public and private hospitals was the legal position of the personnel. The hospital staff of a public hospital was employed by the civil administration (Central Government, municipality or province) and had the status of civil servant. The employees of private hospitals went without such a status. A new category of private hospitals appeared by the end of the $19^{\text {th }}$ century, the company hospital. At first these hospitals were small estate hospitals, occasionally visited by a Western doctor. From about 1890, combined efforts succeeded in establishing large central company hospitals with one or more permanently resident medical doctors.

58 L. Hesselink, Healers on the colonial market, native doctors and midwives in the Dutch East Indies (Leiden 2011 ) 295.

59 Koloniaal Verslag 1902, Annex R, in: Handelingen der Staten-Generaal (Proceedings Houses of Parliament, Colonial Report 1902). 


\section{Chinese Hospitals}

Although the government recognized these hospitals as public hospitals by the end of the $19^{\text {th }}$ century, they had for some time a distinctly private character and therefore I have arranged them within this category. As we saw before, already in 1640 the first Chinese hospital had been founded at Batavia by the so-called Boedelmeesters, a college of four regents who collected funds at the occasion of Chinese weddings and funerals and who financed facilities for the Chinese community. In 1801, a new Chinese hospital had been built outside the old town of Batavia near the Waterpoort (Watergate) and in the neighbourhood of the Chinese kampong. The fate of this third institution (before there had been a new building in 1667) was disastrous, already in 1824 it needed to be entirely rebuilt. The patients were sick Chinese persons, insane patients and wounded individuals of the indigenous population. This hospital was given an important role in taking care of psychiatric patients during the first part of the century, when it became the central institution for psychiatric patients, sent from all parts of Java and some of the Outer Provinces. In 1845, the hospital again needed repairs and was partly renovated. Three new wards were added and a separate ward for female patients, a room for anatomy and a covered walkway in front of the psychiatric wards. The total reconstruction budget amounted to $f 52,000$. Some years before, the number of in-patients had grown to more than 160 (31 December 1838: 167), of whom about $40 \%$ were psychiatric patients. The number of leprosy patients had declined to 1.

Not only at Batavia but also at Semarang, the Chinese community tried to establish a hospital of its own. In 1827 one of the appointed Chinese trustees ran away with the gathered funds. They had to wait until 1845 , before the building was established. The building was situated next to the Beggars' Home on the road to Salatiga, about $5 \mathrm{~km}$ from the town. In 1852, after an inspection by the chief of the Medical Service, W. Bosch, the building was considered to be acceptable. Nevertheless, there was too little supervision and little attention given to order and hygiene. On the Outer Islands, two Chinese hospitals were built, one on the island of Riouw in 1828 and one on Bangka in 1849. Both were used to house Chinese leprosy patients (See section specialized Hospitals hereafter).

\section{Company hospitals}

In 1870, following the end of the Cultuurstelsel, many initiatives were taken to start private enterprise, especially in the crops that had proven to be profitable for the world market. Mining and oil companies joined these initiatives.

The plantation companies that were set up on Sumatra at the end of the $19^{\text {th }}$ century had to find a solution for many difficulties. These problems varied from finding suitable land, the ways to cultivate it, selection of crops, the establishing of good relations with local rulers and recruiting of suitable workers. 
Recruitment of workers and retaining them, remained the biggest problem of the plantation owners for a long time. Many of the workers arrived on the estates with health problems or became ill, died or disappeared during their contracts. Especially on the East Coast of Sumatra, this was very troublesome and was a reason for the plantation owners to find ways to procure health care for their workers. When they omitted these measures, they were soon confronted with the heavy burden of replacement of dead and sick coolies. The Coolie Ordinance of 1880 formalized the obligation for plantation-owners to look after the health of their workers. The regulations of the Ordinance stated that the planters had the duty to look after lodgings, regular pay, food and free medical care of their workers. ${ }^{60}$

Actually, after 1880, this was a new category (after VOC and Military) to be engaged in hospital business. The plantation owners decided to found small estate hospitals and appointed doctors to look after their sick employees. After some time, not only on Java, but especially on Sumatra, companies joined forces and replaced the small facilities, which they had organized on their own, by large hospitals for a number of companies together. ${ }^{61}$

\section{Specialized hospitals}

Already in the $18^{\text {th }}$ century, separate hospitals were founded for patients with the same category of diseases or for groups of patients who needed special treatment. Previously, leprosy hospitals were the most common type of specialized hospitals. These hospitals were mostly situated in isolated places because of the danger of infection for the surrounding population. In the $19^{\text {th }}$ century, new types of specialized hospitals were founded, such as hospitals for syphilitic patients, for beriberi patients and for psychiatric patients.

\section{Leprosy institutions}

With respect to care of leprosy patients, a remarkable development occurred in the $1870 \mathrm{~s}$ and 1880s. A few decades ago, in 1868, the NI Government had considered the question whether there was a necessity to issue regulations for leprosy patients. The answer to this question had been negative. This answer was inspired by advice from medical doctors and by messages from heads of regional administration. Both groups had studied leprosy in their neighbourhoods. They had found no evidence that leprosy was contagious. They were of the opinion that it was hereditary, but there was no danger to be feared from leprosy victims freely moving around in the community. At that time, there were about eight leprosy institutions in the Netherlands Indies. A number of leprosy facilities has been established in VOC era. This category of institutions was the victim of rather whimsical policies. Now and again the existing facilities were neglected and then suddenly new establishments were

\footnotetext{
60 G.T. Haneveld, "From slave hospital to reliable health care; medical work on the plantations of Sumatra's East Coast ", in: Dutch Medicine in the Malay Archipelago 1816-1942, A.M. Luyendijk-Elshout ed. (Amsterdam 1989) 73-85.

61 E. van de Velde, "Het Hospitaalwezen op Sumatra's Oostkust”, Het Ziekenhuis, nrs. 9, 10 and 11 (1918).
} 
initiated. Sometimes, facilities were established in the neighbourhood of cities, at other times, they were moved towards isolated islands.

This uncertain future for patients suffering from leprosy was continued in the $19^{\text {th }}$ century, when government policy switched from an active attitude holding the view that leprosy was an infectious and transmittable disease towards the opposite opinion. As a consequence, at first leprosy institutions were built to house the affected people, while later these facilities were abandoned. In the Netherlands Indies such institutions could be found outside Java, on the Moluccas, the island of Celebes, Riouw and some other places. Schoute mentions, around 1850, that there were nine institutions for leprosy of which four were in the Moluccas, two on Celebes, one on Sumatra, one on Riouw and one on Bangka.

The head of the Medical Service on Java held a census among the residencies in 1853 and came to a figure of 2,239 leprosy cases, which was estimated to be too high, possibly because all kinds of skin diseases had been included. The reports showed that the number of inpatients had decreased for quite some time. Thereupon, the government decided to ask for an extensive survey with recommendations as to the necessity and the possibility to isolate leprosy cases. Based on the findings of this research, the Council of the Netherlands Indies arrived at the conclusion that leprosy was not contagious and that therefore leprosy patients should not be compelled to leave society and become hospitalized in leprosy institutions. Those who had been inmates for some time could stay on a voluntary base. Others with leprosy could be admitted into general hospitals for treatment. Care of leprosy patients became a matter for charity institutions and there was no need for the government to intervene.

During the $19^{\text {th }}$ century many discussions took place in countries such as British India, the Netherlands Indies and others, where leprosy was found. Sometimes, because of pressure from the population or by new discussions, the balance turned to the opposite conclusion and governments took legal provisions to forcibly confine leprosy patients.

Throughout the $19^{\text {th }}$ century new initiatives were taken, mostly on the Outer Islands. Not all the dates of initiatives are known, but the following could be traced: In the Moluccas, on the island of Molanen, a totally new institution replaced the deserted one in 1853. For Banda there was a home for lepers on Poelau Pisang, since 1853, but possibly founded much earlier. An institution on Ternate had been the subject of a report in 1829 . The Sultan had the establishment removed to Castella. In 1856, it underwent a considerable restoration. On Celebes, in the northern part near Menado, a leprosy facility was founded in 1846 on the nearly inaccessible island of Bangka. ${ }^{62}$ It was removed to the mainland, at Tumumpah, in 1855 and on the same island Celebes in the region Gorontalo a home was founded at Modelemo in 1856. On Riouw, a Chinese hospital was built in 1828. Soon

62 Next to the island of Bangka to the East of Sumatra, there is a small island Bangka, belonging to the Sangihe-islands north of Celebes. 
after its foundation, it became a home exclusively for leprosy patients. The same happened on the island of Bangka near Sumatra: a large Chinese hospital was founded in 1849 at Rangau. It offered facilities for 300 patients and became a lepers' home from 1851. Sumatra had an establishment for lepers at Mount Felix in the Benkoelen region, since $1847 .{ }^{63}$ (See Appendix 2).

\section{Hospitals for treatment of syphilis}

Lieutenant-Governor Raffles did not only take care of an extensive smallpox vaccination programme, he also embarked upon the fighting of venereal diseases. He ordered the isolation of syphilitic prostitutes by establishing Women's hospitals. The first one was founded in Djokjakarta in 1816. The second Women's hospital was built in Soerabaja in $1820 .^{64}$ Later in this century the policy of the NI authorities concerning syphilis became formulated in regulations of 1852 (averting the harmful consequences resulting from prostitution) and a larger budget became available in the fight against venereal diseases. ${ }^{65}$ These regulations followed the French system: registration of all prostitutes, compulsory examination, if necessary followed by treatment and the assembling of the women in brothels wherever possible. The regulations became operative in most Residencies of Java and in some places in the Outer Provinces. The effect of all these measures was questionable and so the 1852 regulation was withdrawn in 1874 . The combat against prostitution became a matter of "police regulations" henceforth, and entrusted to the local authorities.

Schoute remarks in a comparison with the struggle against smallpox: "we may say that the latter struggle subjected the population to moderate inconveniences, as compared with the essential advantages obtained, while the struggle against syphilis often brought about serious inconveniences in exchange for doubtful gain." 66

In 1816 a small hospital at Djokjakarta was built next to the river near the fort and accommodated 80 women. Care of the patients was in the hands of two Javanese supervisors, a Javanese cook and four coolies for the rough work. A local physician took care of the medical attendance. During the Java War (1825-1830) the hospital was evacuated and was used for military purposes. It was never re-opened. At Soerabaja, a women's hospital was built in 1820 and experienced some repairs, but no inspection report could be traced in the years thereafter. It disappeared from the scene. In 1851, W. Bosch, head of the medical services, found 180 women with venereal diseases heaped up in far too small wards of the City Dressing Station. About the same time, it was reported that many prostitutes together with other sick but free civilians were nursed in prisons, whilst institutions for syphilitic

63 Schoute, Occidental therapeutics, 173-176.

64 Schoute, "De Geneeskunde in NI", GTNI 74 (1934) 1174.

65 Bijblad IS of 1852 no. 1255 (Supplement on the Indian Statutebook).

66 Schoute, Occidental Therapeutics, 155 - 159. 
prostitutes admitted patients with other diseases. The NI Government urged to abandon this practice and if possible (in view of the finances needed) to establish general hospitals for native people that could deliver the appropriate care in different departments.

Twelve hospitals for syphilitic women were counted in 1877 and by the end of the $19^{\text {th }}$ century, this number had increased to 24 . The size of the problem was far bigger than the capacity of these institutions was able to provide. Moreover, much discussion took place about a more effective way of dealing with the consequences of prostitution.

\section{Psychiatric hospitals ${ }^{67}$}

The developments of psychiatric institutions during the $19^{\text {th }}$ century deserve special attention. In part, they reflect events in the Netherlands.

By way of the so-called Humane Decree of King Willem I (April 1818), the King ordered an examination of the performance of krankzinnigengestichten (foundations for the insane) and determine the purpose of these institutions. Their focus should be on curing the patients instead of keeping them lifelong in hospitals. The King tried to centralize the care of poor people, the care of Gasthuizen and the care for the insane. However, the opposition was very strong against the King's effort to change the situation in these fields. The governors of these institutions and the lower administrative bodies like municipalities and provinces were determined to remain in charge. ${ }^{68}$ In the meantime, from about halfway the 1820 s, efforts were made to reorganize the Dolhuizen (hospitals for the insane) and to improve the treatment, so that the character of these institutions became more curative.

In 1841, the first Krankzinnigenwet (Insanity Law) was passed. ${ }^{69}$ Thereafter, a remarkable improvement in care took place in accordance with the new science of asylum management. This new approach in treatment of psychiatric patients comprised a non-restraint policy and inventive use of the asylum environment by introducing work therapy in horticulture and agriculture. In 1849, a modern new psychiatric hospital, named Meerenberg, was founded by the province of North Holland in Santpoort.

The course of the new developments in the Netherlands Indies was initiated by the chief of the Military Medical Service, G. Wassink, who in 1856 investigated the location of the insane on Java and Madoera. Much attention was given to this subject and an inventory study was made to chart the needs on Java for krankzinnigengestichten (psychiatric hospitals). The outcome of this study was that a total capacity of 300 beds was considered to be sufficient to cover the needs on Java. This outcome became the object of disagreement between the Dutch and NI health authorities. King Willem III intervened and initiated an

67 C. Swaving, "Het Centraal Krankzinnigengesticht te Buitenzorg" GTNI 20 (1880) 337- 379.

68 Houwaart, De hygiënisten, 41.

69 Prof.dr. Schroeder van der Kolk, director of the Willem Arntsz Foundation, a krankzinnigengesticht at Utrecht had a great influence on the new developments and also the psychiatrist and author Frederik van Eeden, who described the prevailing abuses in his novel "van de koele meren des doods" (about the cool lakes of death). 
expert commission to look again into the real need of psychiatric facilities on Java. The ultimate recommendation was that a large, specialized hospital should be established in West Java, complemented by 2 auxiliary hospitals in East Java. The first psychiatric hospital was established at Buitenzorg near Batavia, in 1882. This new hospital could be compared with the most recent modern psychiatric hospital in The Netherlands, Meerenberg.

The central hospital at Buitenzorg was established in a prolonged building project. It started its activities in 1882 and was, compared to the newly built model psychiatric hospital at Santpoort, of royal dimensions and costs: for 212 patients at Buitenzorg the same annual amount was spent, as for 800 patients in Meerenberg. The Buitenzorg hospital gradually acquired extensions and the initially planned capacity of 500 beds was finally achieved. The hospital was situated in an environment with moderate and cool temperatures, away from the unhealthy surroundings of Batavia and with ample space to expand its agrarian compound and buildings for therapeutic activities.

The so-called "non-restraint" system, that tried to improve the humane and enlightened treatment of the insane, was introduced at the start of this hospital. It was fully applied in 1898. Together with the Buitenzorg hospital, two auxiliary hospitals at Semarang (Mid-Java) and Soerabaja (East Java) were maintained for some time, each with a capacity of about 100 patients. In the Outer Islands no mention was made of specialized psychiatric institutions during the $19^{\text {th }}$ century. From then on the care of the mentally ill received continuous attention from the authorities and a more or less autonomous status in the health policy of the colony.

\section{Beriberi hospitals}

Beriberi was a disease, already mentioned by Bontius in the VOC era. Schoute mentioned a scene in which a German surgeon by name of Frikius received a remarkable treatment. Probably he suffered from beriberi. The disease was found particularly among convicts and in war conditions. During the Atjeh war (1879-1909), many soldiers were affected.

Two hospitals took care of the beriberi patients: one at Weltevreden near Batavia and one on Sumatra near Padang at Oeloe Limau Manis. The last one took care of the coolies who were serving in the Atjeh war. Beside convicts and war victims, coolies at the plantations on Sumatra's East Coast also suffered from this disease. Especially in the second half of the $19^{\text {th }}$ century, the number of patients increased to extreme proportions. This was why the convalescent home Kampong Makasser near Batavia was asked to help. The opening of both establishments took place at the end of the 1880s and the Koloniale Verslagen soon reported satisfying results that this change of air and surroundings had on the many patients suffering from beriberi. By the end of 1888, the hospital at Buitenzorg already counted on average 1,136 patients. 


\section{Convalescent homes}

Three convalescent homes were founded in the course of the $19^{\text {th }}$ century. The one at Kampong Makasser, already mentioned, one at Buitenzorg, Gadok and one in the Preanger Regency, Sindanglaija. The latter two were private institutions that received subsidy from the government on condition that civil servants and army officers should be treated at reduced prices.

\section{Quarantine facilities}

A few hospitals, mainly situated near large harbours, occasionally experienced considerable pressure in their usual activities, when infectious diseases were imported from abroad. In these cases, extensions or annexes were established and sometimes a separate hospital was built. The extensions were often nothing more than barracks or sheds with very poor equipment. In 1879, a license was issued by the authorities to build two new loodsen (sheds) to nurse victims of cholera and smallpox next to the City Dressing Station at Batavia. A total of 196 cholera patients were admitted into the new facility of whom 91 died. In Soerabaja the problem of evacuation of infectious patients from the ships to a hospital in town was met by building a so-called cholera hospital on the river Oedjoeng.

\section{SUMMARY}

The transition from the VOC-situation to health care in the $19^{\text {th }}$ century was less abrupt than the political transitions that took place from 1795 to 1816. Some civil hospitals continued their existence and new ones were established. However, for quite some time they suffered from neglect, were given very basic budgets and deteriorated. By the end of the century a better and promising future could be expected for civil hospitals, as were founded new and modern company hospitals and missionary hospitals. The old City Dressing Stations had to wait until the $20^{\text {th }}$ century for new and better conditions.

On the positive side of the balance may be noted:

- The effects of a thorough vaccination programme that substantially diminished the death-rate by smallpox in children.

- The results of a training programme and a school for indigenous physicians substantially increased the capacity to treat patients in the NI.

- The penetration of Western health care in the NI after three centuries of founding, running hospitals and educating doctors. See Table 3 in the previous paragraph.

- There was improvement in psychiatric care by establishing psychiatric hospitals with modern therapeutic programmes such as occupational therapy in agriculture and horticulture.

- Preventive actions were undertaken to fight malaria by supplying quinine, by establishing sanitation works (assaineering) and by supplying a higher quality of water. 


\section{Two observations may be added}

The problems encountered in the Indies were not unique to tropical countries: malaria or "marsh fever" was still endemic in low-lying and swampy parts of Europe. Porter mentions that long before germ theory appeared, Dutch and British officers had tried to create sanitary encampments for their troops, developing a rule-of-thumb military hygiene based upon the miasmatic view that diseases came out of the earth..$^{70}$ This view was also cherished by the authors of treatises on hospital buildings. They brought out reports with recommendations for healthy hospital locations. 
MAP 2 HOSPITALS ARCHIPELAGO 1890

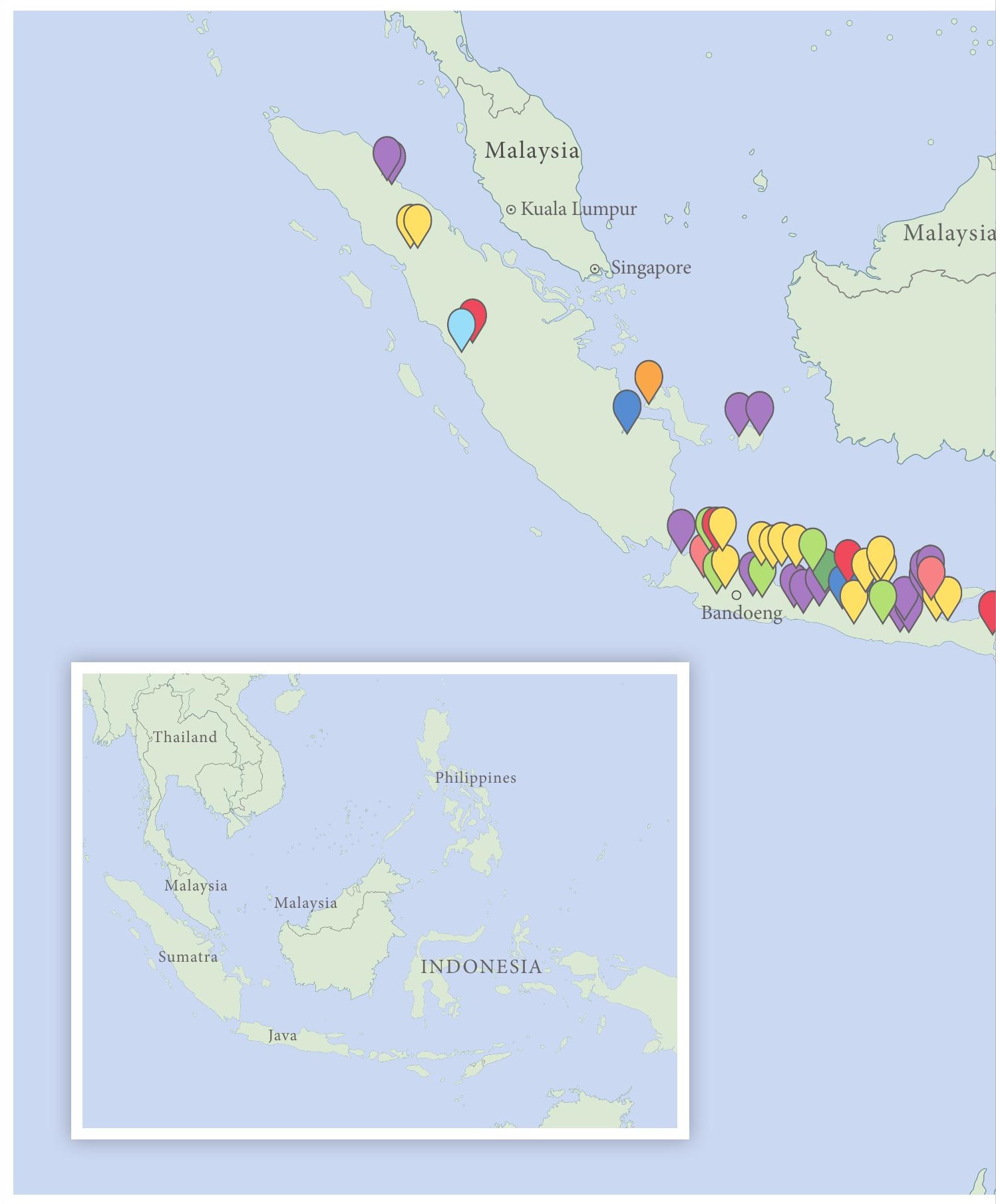




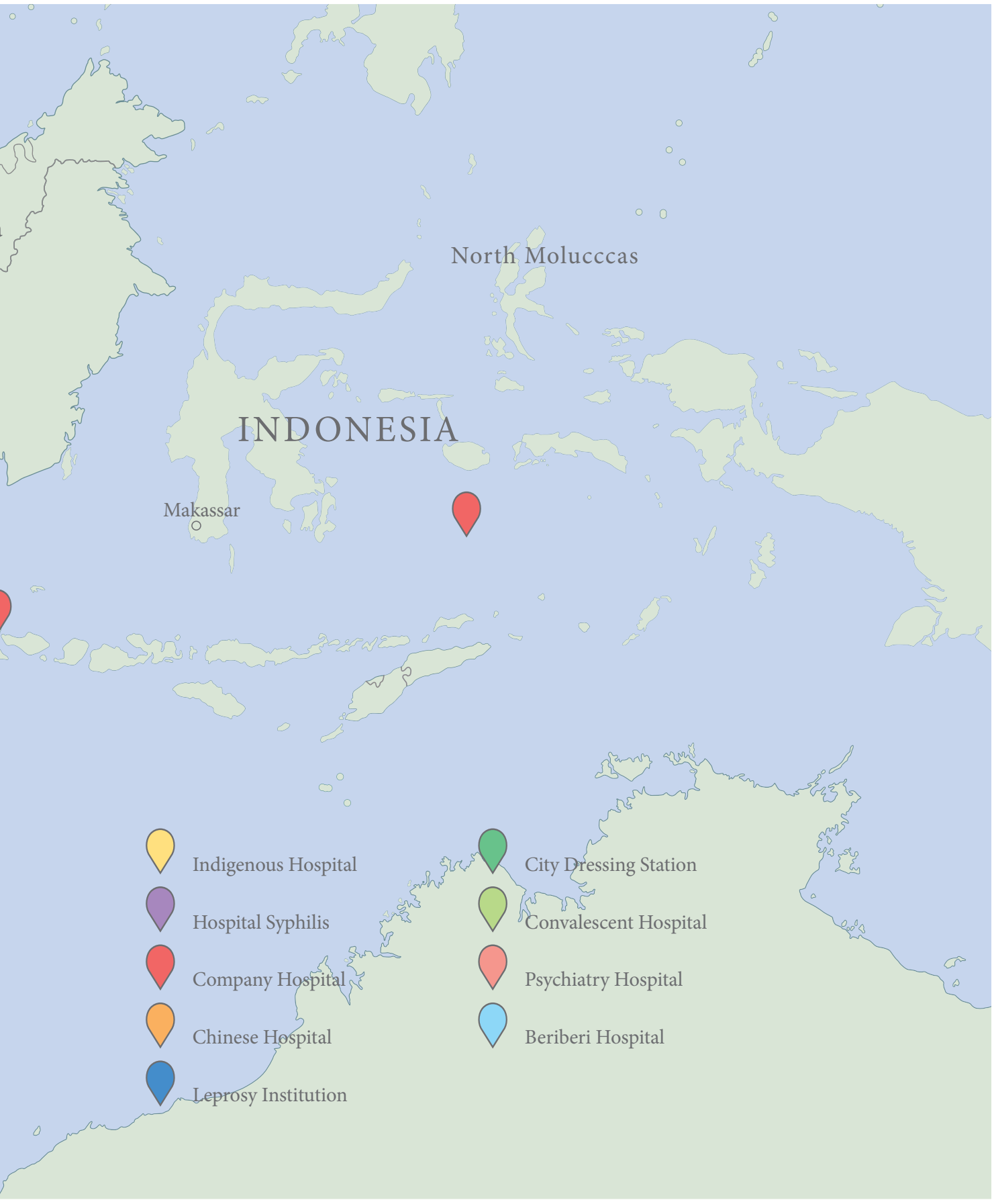




\section{MAP 3 HOSPITALS JAVA 1890}

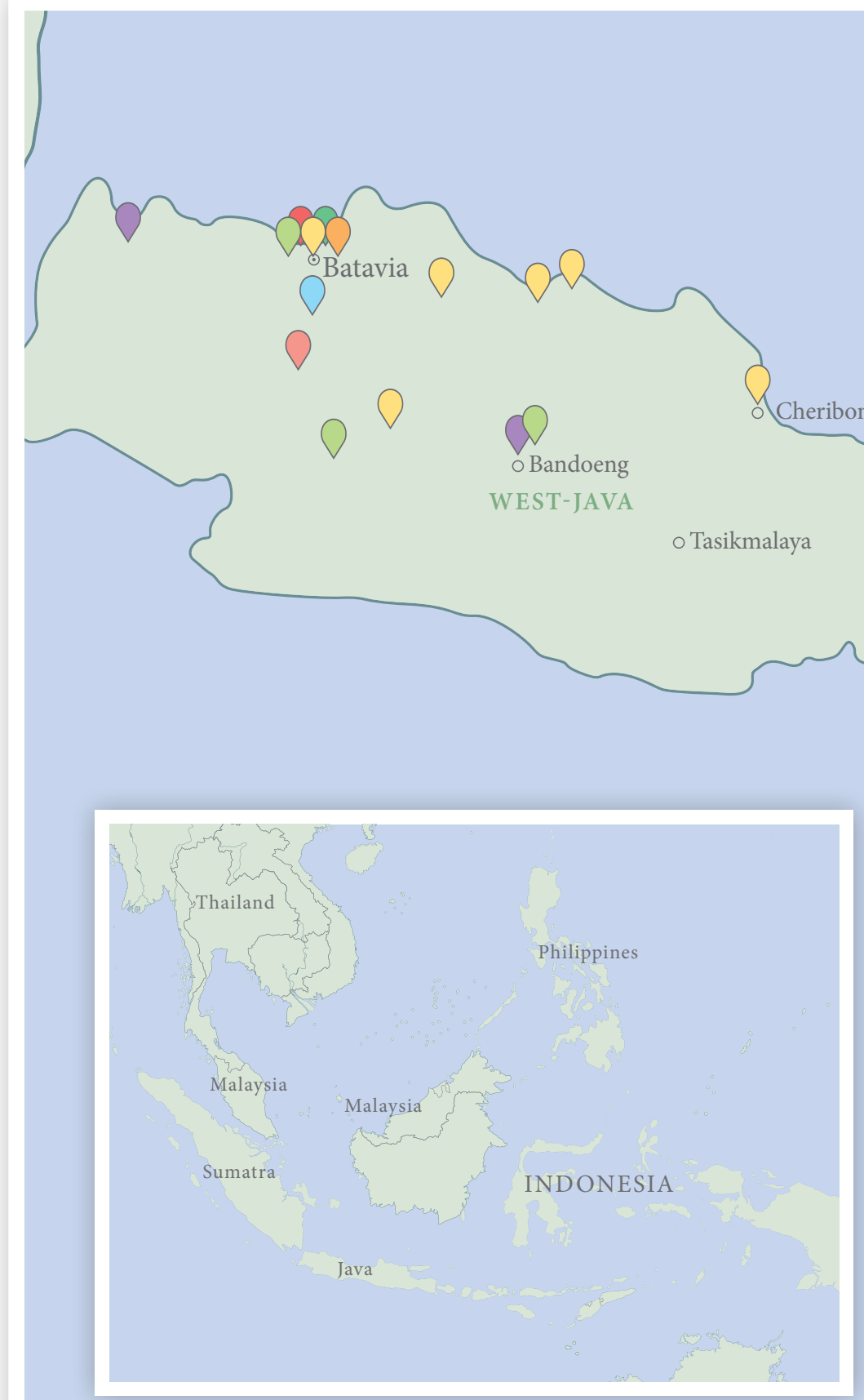




\section{Javazee}
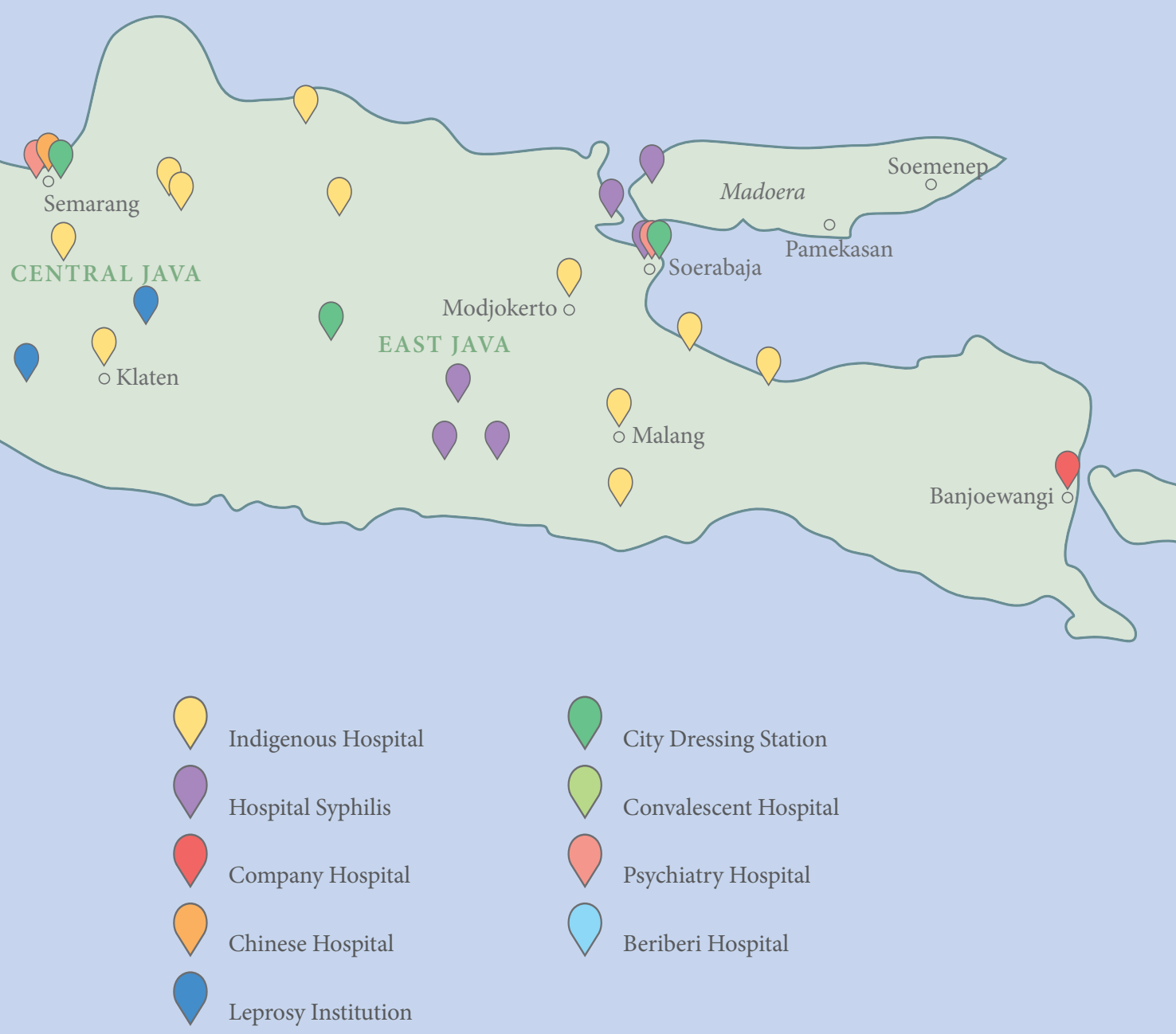



\section{CHAPTER 4}

A PERIOD OF TURMOIL (1890-1910) 


\section{INTRODUCTION}

At the end of the $19^{\text {th }}$ century a wind of change went through the Netherlands Indies (NI). In The Netherlands, there occurred a fundamental change in the political climate. New views and premises were formulated concerning colonial policy. They had an important influence on the development of health care and education in the Netherlands Indies after 1890.

Changes took place in almost every sector of the colonial world: the economy, politics, military, social and political philosophy, education and in health care. The end of the Cultuurstelsel (System of forced labour and forced growing of agricultural crops) in 1870 had been the prelude. From then on, private parties were given more opportunities to expand agriculture, mining and commercial activities. In the field of medicine, discoveries took place that shook long held views. For a long time, medical science had found no answer to the challenges of endemic diseases in the archipelago. The turn of the century brought the hope that solutions could be attained for tropical diseases such as yaws and beriberi. In this field, some promising discoveries were made by medical science. A new discipline of Tropical Medicine was developed around 1900 and will be discussed in one of the following paragraphs.

The last decennia of the 19th century saw a worldwide increase in imperialistic tendencies, especially characteristic for some European countries. The Netherlands tried to pacify parts of the Indonesian archipelago that until then had not been under colonial rule. In several regions the Dutch army undertook campaigns. The rulers of these regions resisted the attack on their independence, which caused a lot of misery and many casualties. In the end, the military force won and the regions concerned came under colonial rule. The new relation meant a formal subjection of local princes and sultans to the colonial administration. The hitherto reigning rulers kept a certain autonomy, but a limited one. Throughout the country, government officials represented the real power.

In this chapter, the development of Western health care is followed on Java and on the Outer Islands during the two decennia around the turn of the century. This development came about through different actors, varying from initiatives by local communities or population groups, initiatives of plantation estates, by Roman Catholic or Protestant missions, by the military and by the colonial Government. These actors initiated new hospitals or improved and extended existing institutions. They did so, inspired by a variety of motives and incentives.

\section{THE RISE OF MODERN IMPERIALISM IN THE INDIES}

The Netherlands acted on several fronts to strengthen its authority in the colonies during the years 1890-1910. Before embarking on military expeditions, the Dutch had made arrangements with the British on the borders of Borneo (1895), Sumatra and Malacca (1824 and 1871), with the Portuguese about East-Timor (1895). The Germans and British 
acknowledged the boundaries of New-Guinea, drawn up autonomously by the Dutch. ${ }^{1}$ After these political arrangements had been settled, military expeditions started to conquer areas of economic or political interest in the archipelago.

An example of such expeditions is the ferocious fight that took place to conquer Atjeh, the strategically situated area in Northern Sumatra. This war caused many casualties under the civil population and the fighting parties. The war continued for more than 30 years, but the fiercest struggle took place between 1899 and 1909. Almost $4 \%$ of the population was killed. Other parts of Sumatra were likewise theatres of war: Jambi and Tapanoeli (the land of the Batak people) from 1906 to 1907. A few years before, expeditions were organized in southeast and central Borneo. Military expeditions were also held in central and south Celebes. Notorious was the war on Bali that led to the puputan, the massive ritual suicide of the entire royal family.

Previously, in 1894, the Balinese nobles who exercised power on the Sasaks of Lombok had slaughtered Dutch troops that came to the help of the Sasaks. The Lombok expedition that followed caused enormous ravages on the island of Lombok. De Jong assumes that this expedition was a turning point both psychologically and emotionally for colonial policy in the NI. ${ }^{2}$ "Among large groups within the politically active upper-class came about a new nationalist, imperialistic state of mind which carried with it and justified an urge towards expansion. At the same time this new attitude made an end to the politics of nonintervention. Actually, this new ideology formed another important tool of empire, which got a strong ethical load at the approach of the new century." ${ }^{3}$ Van Goor is of the same opinion. He states that the military success of the Lombok expedition of 1894 gave a new and strong impetus to Dutch nationalism and that this victory strengthened the belief in the Dutch mission for the Indies. ${ }^{4}$

Following the successful military expeditions by the Dutch, contracts were made with the vanquished rulers and sultans. In 1904, the old war-horse J.B. van Heutsz (1851-1924) was appointed Governor-General and he took over the so-called Korte Verklaring (Short Contract), designed by the well-known advisor of the government, C. Snouck Hurgronje (1857-1936). ${ }^{5}$ This Verklaring contained only three articles:

- The ruler admitted that his territory was under Dutch rule

- The ruler promised not to enter into political relations with foreign powers

- The ruler agreed to comply with all rules and orders the Dutch should prescribe regarding the governance and administration of his lands.

1 J. van Goor, De Nederlandse Koloniën, geschiedenis van de Nederlandse expansie 1600-1975 Transl.: The Dutch Colonies, history of Dutch expansion 1600-1975 (Bilthoven 1997).

2 J. de Jong, De waaier van het fortuin, 331.

3 Translated from the Dutch text.

4 J. van Goor, De Nederlandse Koloniën, 261.

5 J. S. Furnivall, Netherlands India, a study of plural economy (Amsterdam 1976) 236-237. The Korte Verklaring was first adopted in 1898. 
For the health care of the NI, this meant that initiatives in these territories no longer depended on the consent of the ruling prince or sultan. This had hardly been an issue previously, as private initiatives in the field of health care were nearly absent for most of the $19^{\text {th }}$ century. Only from 1890 onward, as missionary and other initiatives took a more substantial course, could the influence of the indigenous authorities hinder their ambitions. One example of this were the problems the missionary J.G. Scheurer encountered with the ruler of Solo in the 1890s, when he tried to start medical work in this principality. Scheurer moved then to Djokjakarta where the ruling prince encouraged his initiatives to start a hospital in that town. Sultan Hamengkoe Boewono VII put 28,410 square meters at the disposal of the mission to build a hospital, houses for the hospital staff, a school and other buildings. ${ }^{6}$

\section{Economic developments}

The expansion policies also served economic interests. According to de Jong the saving of the Royal Dutch Oil Company, established in 1890, but now stagnant because of the desiccated oil wells of Langkat, inspired the last ferocious fights to conquer Atjeh, a potentially important oil-region. ${ }^{7}$ The Lombok expedition was followed by a government decision to have all import and export of the West Coast of Lombok licensed, closing all the harbours temporarily for foreign ships and opening a direct line Singapore- MakassarBali-Lombok. This proved to be a golden opportunity for the still young Koninklijke Paketvaart Maatschappij (1888). ${ }^{8}$ This company was founded to recapture the sea traffic that had become monopolized by English ships. ${ }^{9}$ It meant the death-blow for its competitor, a Singapore ship-owner. ${ }^{10}$

The ancient VOC mentality seized the Dutch and their commercial interests once again. Prior to the empire building depicted before, the much vilified Cultuurstelsel with forced labour and forced cultures had come to an end. This same system had benefited the Dutch public treasury: the annual net profits (Batig Slot) resulted in a surplus, after it had been in deficit for a long time during the $19^{\text {th }}$ century.

Whilst the private plantation estates were soon on their way, the mining and oil companies only started their activities towards the end of the $19^{\text {th }}$ century. In 1887, the first oil company was founded on Sumatra, followed in 1892 by the 'Koninklijke', but in 1897 already 16 oil companies existed on Java and the Outer Islands. ${ }^{11}$

\footnotetext{
“De Gereformeerde zending in Midden-Java 1859-1931", een bronnenpublicatie, H. Reenders ed., document 71, $294-295$. J. de Jong, De waaier van het fortuin, 331-333.

Royal Company for Package Transport.

Furnivall, Netherlands India, 331.

10 The Singapore ship-owner Wee Bin, who had frustrated the Dutch by delivering repeating rifles to the royal house of Lombok.

11 Of which 8 were established on Java, 7 on Sumatra and 1 on Borneo. (Fasseur, 359-360).
} 


\section{The ethical movement and legislation}

As these economic developments took place and business expanded vastly on Java and Sumatra, a parliamentary dispute occurred in The Netherlands. The discussion was about how the colonies were ruled. A growing number of members of parliament wanted a fundamental change. They thought it immoral that the Netherlands Indies had to pay for Dutch deficits. The looting of this vast archipelago to the benefit of the Dutch treasury could not be tolerated any longer.

In 1899, C.Th. van Deventer, a liberal member of parliament wrote an article that was published in De Gids. ${ }^{12}$ Its title was "Eereschuld" (Debt of honour) and he proposed to return to the Netherlands Indies all the money earned with the Cultuurstelsel. This publication contributed to a change of colonial policy. More people promoted the view that colonies ought to be developed and that the colonial power should take responsibility to achieve this goal. Gradually, this ethical view acquired a majority in parliament.

This culminated in the Troonrede of 1901 in which Queen Wilhelmina introduced this new policy. ${ }^{13}$ "As a Christian nation The Netherlands have the obligation to improve the legal status of indigenous Christians in the archipelago, to support the Christian mission and to inspire the governmental policy with the notion that our country has a moral obligation towards the population of the colony. Our special attention should go to the decreased prosperity of the indigenous people of Java. We wish to investigate the specific causes of this situation. We shall seriously look after the protection of coolies who work under contract. We shall promote the decentralization of the Netherlands Indies administration." ${ }^{14}$ Because of this new policy, the initiatives to start missionary hospitals in the NI could count on a more co-operative attitude from the side of the NI administration.

The successive cabinets of Kuyper (1901-1905) and De Meester (1905-1908) attempted to meet a number of the objectives voiced in the Troonrede.

1. The Protestant and Roman Catholic missions soon experienced more co-operation from the side of the colonial government. The NI government enabled and encouraged their work in churches, schools and hospitals by grants, training projects and subsidies.

2. In 1905, a commission was appointed to investigate into the causes of decreased prosperity of the Javanese people. Its members systematically enquired into the various branches of industry, agriculture, forestry, fishing, livestock, commerce, transportation, irrigation and justice. Their research produced 12 voluminous reports, which were

\footnotetext{
2 C.Th. van Deventer, "Eereschuld", De Gids (1899), 205-252.

3 Oration of the monarch to celebrate the opening of the parliamentary year.

14 Translated by author
} 
published in the years 1905 to $1914 .^{15}$

3. The NI Government proclaimed the Decentralization Law in 1903. This Law made it possible for regional and local councils to participate in the administration. Residencycouncils were appointed, first for the large cities of Java (1905), then for each Residency of Java (1907) and for the important tobacco region in East-Sumatra (1908) and subsequently councils were established for some of the smaller towns and some rural areas. $^{16}$

4. The NI Government issued regulations to subsidize the founding, maintenance and running costs of indigenous hospitals in $1906 .{ }^{17}$ Hospitals could be given a grant to buy land for construction and a grant for inventory. They could also receive an annual subsidy, the amount of which depended on the presence of doctors and on the number of staff. ${ }^{18}$

5. The Labour Inspection was established in 1907. Its mission was to monitor labour conditions.

Thus started in the new century a programme on emancipation, education and emigration. In the administrative and agricultural field, the objectives were formulated: decentralization and irrigation.

\section{The other side of the story}

The account concerning the colonial activities thus far has been given from the Dutch point of view. How the Indonesian society functioned and which forces were at work within it to achieve non-colonial social interests would soon become manifest. Wahidin Soedirohoesodo, an indigenous doctor trained at the STOVIA, propagated the creation of a study fund to finance western-type education among students ${ }^{19}$ This action took place in the first years of the new century. In 1908, he and his friends founded the Association Budi Utomo (Beautiful Endeavour). The primary goal of the new organization was to further better and more education, but soon political aspirations were formulated as well by some members.

15 Onderzoek naar de mindere welvaart der inlandsche bevolking op Java en Madoera, deel I Vischteelt en visscherij; deel II Pluimveeteelt; deel III Veeteelt; deel IV Vervoerwezen; deel V-landbouw; deel VI Handel en nijverheid; deel VII-irrigatie; deel VIII Recht en politie; deel IX Economie van de desa; deel X Eindverhandelingen; Deel XI Voorstellen en besluiten van de Welvaartcommissie in 1914; deel XII Oorzaken der mindere welvaart. Landsdrukkerij Batavia (1905-1914) (Enquiry into the decreased prosperity of the population, 1. Fishery; 2. Poultry; 3. Cattle breeding; 4. Public Transport; 5 . Agriculture; 6 . Commerce and Industry; 7. Irrigation; 8. Justice and Police; 9. Economics of the desa; 10. End Proceedings; 11. Propositions and decisions of the Welfare Committee; 12 . Causes of diminished prosperity).

16 J.S. Furnivall, Netherlands India, 271-272.

17 Actually, there were two categories of indigenous hospitals: the public indigenous hospitals, later on mostly rebaptized into GBZ (government civil hospital) and the private ones. The subsidy regulation of 1906 applied a broad definition and arranged the missionary hospitals also into this category.

18 Staatsblad van Nederlandsch-Indië no. 276 van 13 juni 1906, Regelen voor de toekenning van subsidiën uit's Lands Kas ten behoeve van particuliere Inlandsche ziekenhuizen en hulpziekenhuizen. (NI StatutebookI, Rules governing the subsidies for private indigenous hospitals and auxiliary hospitals).

19 The Dokter djawa school (founded in 1851) was rebaptized in Stovia, School Tot Opleiding Van Inlandsche Artsen (School to train indigenous doctors) in 1902 . See chapter $3,19^{\text {th }}$ century, medical science and training. 
This initiative was born in circles of the lower priyayi (Javanese nobility) and received support from the rulers of the Principalities. Their deeply felt ideal was to restore the ancient Javanese kingdom. ${ }^{20}$

With respect to the economic circumstances of the population, the Troonrede mentioned in covert terms the decreased prosperity of the indigenous people of Java. The Dutch government was aware of the economic and social needs of the population. It was aware that the population of Java had increased by $40 \%$ in the last three decades of the $19^{\text {th }}$ century. In 1870, the population consisted of 16.2 million inhabitants. In 1900, it had increased to 28.3 million. ${ }^{21}$ In addition to this population burden, a decrease in employment had occurred from about 1875, when prices for Java's export produce fell. The consequence was that some companies had to reduce activities or even went bankrupt.

In order to decrease the population burden of Java, the government developed a programme to stimulate migration to the other islands. The government sought to improve the food situation by implementing better agricultural methods. The Department of Agriculture (founded in 1905) tried to improve the quality of crops by introducing new rice varieties that could withstand diseases and gave higher yields. A newly created Irrigation Service attempted to promote an important extension of the wet rice acreage. ${ }^{22}$

\section{DEVELOPMENTS IN MEDICAL SCIENCE AND PRACTICE}

A considerable literature exists on the achievements in the fields of bacteriology and parasitology, which took place worldwide during the last decades of the nineteenth century. These developments had an important impact on medicine, as will be seen later. The developments in the field of medical science in the Netherlands Indies itself were also important for the medical practice in the archipelago. The Vereniging tot bevordering der geneeskundige wetenschappen in Nederlands Indie (Association for the advancement of medical science in the NI) had been founded in 1851. Its medical journal Geneeskundig Tijdschrift voor Nederlandsch Indie (GTNI) tried to form a medium in which the medical profession could discuss developments and practical medical problems (see Chapter $3,19^{\text {th }}$ century, $\$$ Medical science and training). In 1887 the Laboratory for Pathological Anatomy and Bacteriology at Weltevreden was founded to facilitate the research of the beriberi disease (See Paragraph Research \& Education). A few years later, in 1891, a Parc Vaccinogène was founded at Batavia. It produced vaccine from animal blood for vaccination against smallpox. The procedure had been developed by a health officer, C.D. Schuckinck Kool at the Batavia suburb Meester Cornelis, already in 1884. In 1894, the adjacent Pasteur-Institute started to produce a vaccine against rabies.

20 De Jong, De Waaier van het Fortuin, 389-390.

21 P. Boomgaard, A.J. Gooszen, Population trends 1795-1942 (Amsterdam 1991) table 4.

22 P. Boomgaard, “De welvaartspolitiek in Nederlands-Indië (1900-1942)", Spiegel Historiael 22 (1987) 382-387. 
All three, the Laboratory at Weltevreden, the Parc Vaccinogène and the Pasteur Institute contributed to the development of modern medicine in the Netherlands Indies. The Pathological Laboratory at Medan (East-coast of Sumatra) was founded by the Plantation Association in 1906. Among others, it carried out research on hookworm disease and on beriberi. The importance of research in the fields of bacteriology, parasitology and nutrition would soon become clear as its results enabled the treatment of diseases that had caused high mortality for a long time.

\section{Popularity of indigenous medicine}

Boomgaard calls it one of the ironies of history that precisely during the period of the great breakthroughs of Western medicine at the end of the $19^{\text {th }}$ century the European and Eurasian lay population was drawn into the sphere of influence of indigenous medicine. European and Eurasian ladies wrote books on Javanese drugs and healing practices for a lay public and these books were so popular that they got several reprints. Often the European and Eurasian population relied more on these books and on indigenous healers than on European physicians. The author explains that this might be due to the shortage of European doctors or might be linked to the fact that European medicine was as alien as Europe itself for many families who had resided in Indonesia for generations. ${ }^{23}$

The fact that, at the turn of the century, the quality of the hospitals began to improve and that new discoveries began to be implemented in medical practice, both may have been helpful in removing thresholds, but this was only a necessary condition and not the most decisive one. The population needed to make a shift in thinking in which its pattern of life could make place for modern phenomena like doctors, midwives and hospitals.

After a period during which the indigenous population had hardly any interest in the services of colonial hospitals, at last the situation changed, and from 1900 the increased number of outpatient visits indicated that western health care and hospitals became a serious option. Impulses came from the nearness of facilities, the outcome demonstrated by friends, family and neighbourhood and most of all the fact that services were rendered free. The shopping between traditional and Western remedies made comparisons possible and helped to get used to new ways of dealing with health problems.

\section{The rise of tropical medicine}

In 1907, the municipal physician of the city of Semarang, W.Th. de Vogel, had been delegated by the Minister of Colonies to the International Congress for Hygiene and Demography in Berlin. ${ }^{24}$ One of the recommendations of this congress was to let national associations

23 Boomgaard, “The development of colonial health care", 77-93.

24 W.Th. de Vogel (1863-1955) was the second chief inspector of the Civil Medical Service (Burgerlijke Geneeskundige Dienst, abbreviated BGD). 
of tropical medicine assemble once every three years to exchange results and ideas in the field of tropical medicine. This intention expedited the founding of the Dutch society, which took place at the end of 1907. De Vogel was among the founders of the Netherlands Association for Tropical medicine. ${ }^{25}$ The aim of this association was to be a forum for the presentation of medical research and clinical case reports in the field of tropical medicine. Before the founding of this Dutch society, a teaching post for tropical diseases had been financed from the colonial budget. From 1900, this teaching took place in the medical laboratory at Weltevreden. G.W. Kiewiet de Jonge was the first lecturer on tropical medicine in the Netherlands Indies. Many discussions were held concerning the location for tropical medicine. In some European countries, such as France, Germany and Great Britain, the tropical institutes were established in the homeland and laboratory work in parasitology and pathological anatomy was situated next to where theoretical lectures were given on tropical diseases.

In Amsterdam and Leiden, two competing institutes were established on tropical medicine for doctors about to join the civil medical service in the Netherlands Indies. ${ }^{26}$ After considerable discussion, both courses were approved by the Dutch Government. The difference in subsidies between the two courses was terminated by a parliamentary vote of 26 February 1918 and the future government doctors or health officers were allowed to make their choice between the Amsterdam or Leiden institute. ${ }^{27}$

\section{Medical surveillance of diseases}

For the purpose of medical surveillance Java and the Outer Provinces had been divided into medical regions, called gezondheidsressorten (health districts). For each health district, a European physician was assigned and in large districts one or two dokters djawa as well. Places of settlement of dokters djawa were called standplaats (station). The physician assigned to a district could be a health officer, a local civil doctor appointed by the medical service, a city doctor or a private doctor. In 1890, in most Residencies of Java and the Outer Provinces, the medical districts were staffed. On Java there were 53 health districts with medical doctors and 59 stations with dokters djawa. Sumatra had 29 health districts with European doctors and 15 stations with dokters djawa. The other islands together had 19 European doctors and 20 dokters djawa. In this way a network was created of 101 major and 94 secondary medical posts.

25 Nederlandse Vereeniging voor Tropische Geneeskunde (NVTG).

26 Heteren, G.M. van, “The course in tropical medicine at Amsterdam: 'a case of monopolization'? “, in: Luyendijk-Elshout, A.M. ed., Dutch Medicine in the Malay Archipelago 1816-1942 (Amsterdam 1989) 35-55.

27 The controversy between the two institutes is well documented by Leo van Bergen, who describes how the discussion ultimately led to a parliamentary resolution, in which the choice was left to the doctors who applied for a job in the Indies. See: L. van Bergen, Van koloniale geneeskunde tot internationale gezondheidszorg, een geschiedenis van honderd jaar Nederlandse Vereniging voor Tropische Geneeskunde (Amsterdam 2007) 45-68. 
Information about the medical practice was available in the published scientific reports and in the monthly reports on contagious diseases. The Chief of the Medical Service, J. Haga (1902-1906), made, for the year 1902, a first effort to combine these reports in order to arrive at more accurate medical statistics. ${ }^{28}$ In those reports for the years 1902 and 1910 five categories were created for health issues:

1. contagious diseases and epidemics which took place in that year on Java and Madoera;

2. contagious eye afflictions and leprosy, treated and/or reported by medical doctors in that year;

3. the number and nature of outpatient consultations

4. the number of treated snake bites

5. the effects of Spa treatments

These five health issues were reported for each Residency. Occasionally, figures were given for a disease. The statistics for the years prior to 1900 gave figures and totals for a limited number of diseases. As the quality of statistics was poor, incomplete and inconsistent, the Koloniale Verslagen of a few years were consulted. For the years 1895 to 1899, these Verslagen reported the distribution of the most frequently treated diseases (See Figure 3).

Intermittent fevers, the most important item in the figure, was later known as malaria and appeared to be the largest killer on Java. It represented about $52 \%$ of all reported treatments. Within the list of the five categories that was mentioned before, category 1 was distinguished as most threatening and in many cases considered lethal: cholera and smallpox. ${ }^{29}$ In the years 1895-1899, these diseases occupied about 13,600 (3\%) of all reported treatments. In the same period, 21,065 (6\%) cases of venereal diseases and 8,663 (2\%) cases of beriberi were treated. For the other diseases no figures or percentages were distinguished. Among these were eye diseases, ulcers, skin diseases like yaws and scabies, wounds and diseases of the respiratory and digestive organs. On average, 127,749 patients were treated annually for these categories together (34\%).

\section{THE RISE OF CIVIL HOSPITALS}

Health care in the $19^{\text {th }}$ century had been dominated by the military. Whereas quite a few specialized civil hospitals were established, only a few new general civil hospitals were initiated. From 1890 this situation changed, new parties entered the hospital scene, such as missionary hospitals and hospitals founded by plantation estate owners. Moreover, the

28 J. Haga, "Uit de verslagen van den geneeskundige dienst. Eenige Statistische gegevens ontleend aan de civiel geneeskundige jaarverslagen (Ook wel genoemd wetenschappelijke verslagen) en aan de rapporten omtrent besmettelijke ziekten van Java en Madoera over het jaar 1902." GTNI 43 (1903) 694-725. Over de Buitenbezittingen, 743-788 GTNI 51 (1911) Eenige statistische en andere gegevens over het jaar 1909, 1-76 en 285-401. Transl.: Some statistical data from the annual reports of the civil medical service and from the reports on contagious diseases.

29 The figures demonstrate that the importance of smallpox by 1890 was already diminishing. 


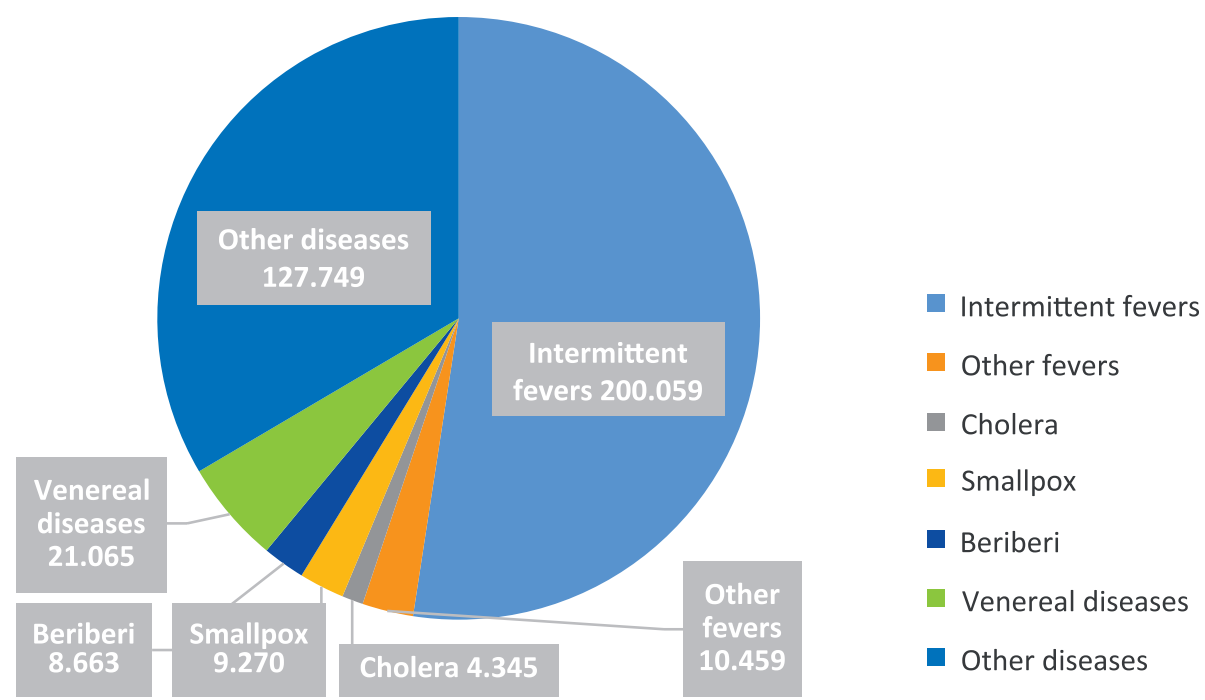

Figure 3 Treatments 1895-1899 (Source: Koloniaal Verslag 1900, Appendix S, II)

attitude of the NI government towards civil hospitals changed drastically by the introduction of the ethical policy.

It would be interesting to know, how the new hospitals appeared. Were they a replica of the European institution, a copy of the Dutch hospital, or did they find their own shape and substance, adapted to the tropical environment, to the colonial context and to specific tropical diseases? To get an answer to these questions, it may help to look at the organization, the architecture, the staffing, the type of services rendered and the hospitals' equipment. Before doing so, we might quickly look at the development of outpatient and inpatient hospital care in the Western hemisphere and try to determine whether the health care infrastructure that the Dutch patient encountered differed from the experience of a patient in the Netherlands Indies.

What were the characteristics of hospitals in Europe at the turn of the century?

As far as the Dutch situation is concerned, Houwaart remarks: "in the period 1880-1920 quite a new practice of hospital care developed, based on a new system of nursing care, based on surgical interventions that shortly before were judged unattainable and based on the integration of diagnostic and therapeutic devices in the hands of the medical doctor. The reorganization of nursing care had made its start in the years '50 and '60 of the $19^{\text {th }}$ century and medical technology would mark the development of hospital care from 1890 onwards." ${ }^{30}$ The description of the metamorphosis of the Massachusetts

30 Houwaart, "De ontwikkeling van het ziekenhuis in de moderne tijd", 322-323. 
General Hospital in about the same period (1870-1930) received the promising title The Invention of the Modern Hospital. In the previous Chapter this study was mentioned and described. The reader may recall that the author depicted the change in the type of services rendered and the introduction of scientific medicine. In the period described a simultaneous change took place in the type of patients served and in the social environment in modern cities. The social changes in the urban context could explain the changes that occurred on the hospital scene. ${ }^{31}$

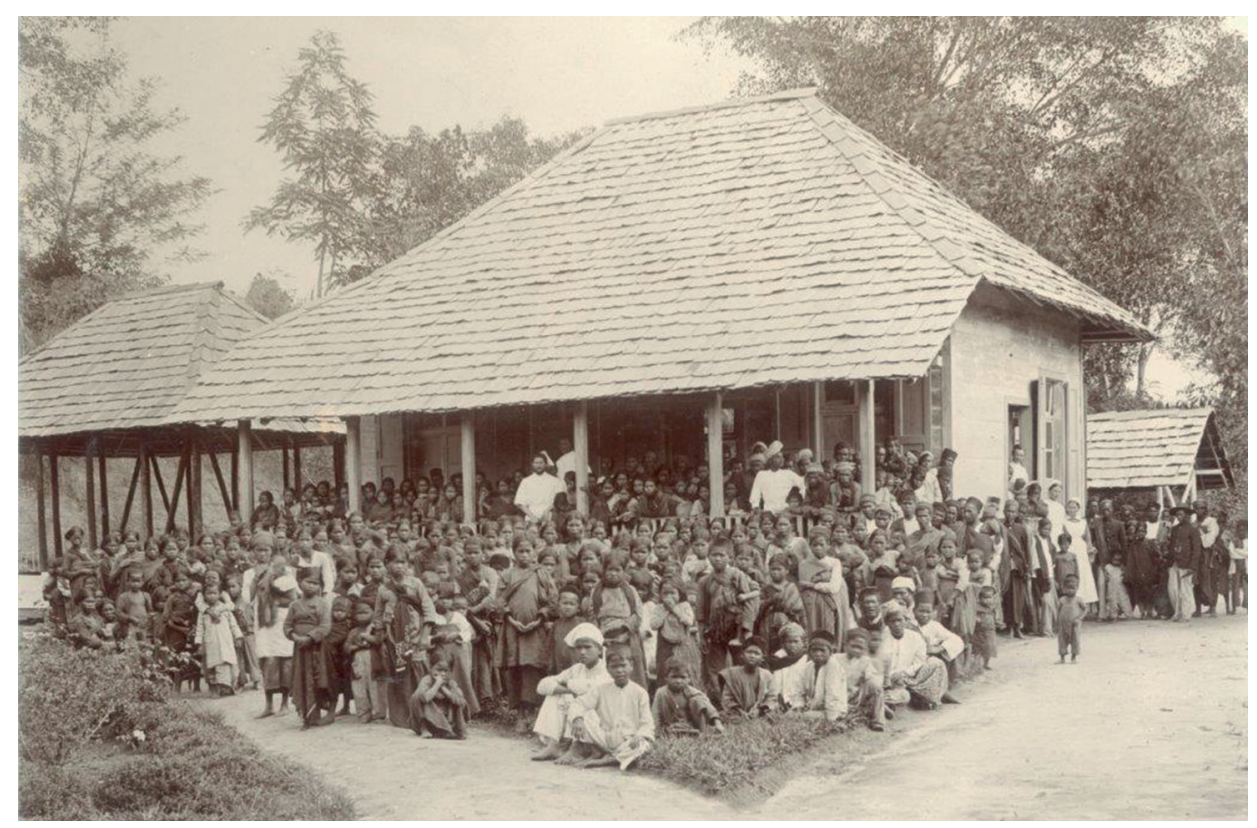

Figure 4 The outpatient clinic of Taroetoeng (West Sumatra) in 1910 (Source: KITLV)

In other colonial situations such as British India, the Philippines and French Indochina hospitals were established by private initiatives and initiatives of the colonial governments. In some colonies the direction was in the hands of the military. This was the case with French Indochina during the first 40 years of colonial rule.

The character of these hospitals was more or less identical to the motherland hospitals with one distinction though: the hospital facilities for Europeans differed from those for the indigenous population. One might say that in this sense the old situation of hospital facilities for the poor found continuation. As the paying middle class patient did fail in the colonial

31 Morris J. Vogel, The invention of the modern hospital: Boston, 1870-1930 (Chicago 1980). 
situation, means for medical and technical progress stayed behind as may be illustrated by the percentage of the total budget that was allocated to health care. E.g. In Indochina hardly more than $1 \%$ of the general budget could be spent by the health authorities. That meant that the health sector of Indochina heavily depended on local budgets and loans.

The history of the Philippines and French Indochina differed from the history of British India and the Netherlands Indies. The first two had a rather young colonial record, being both conquered in the second half of the $19^{\text {th }}$ century, whereas British India and the NI had been under colonial rule for centuries. Still, it makes sense to compare all four examples of colonial health care that emerged from internal and external impulses and measures. Beside the contrast in length of colonial rule, other contrasts may have been more significant. Such as the question, who were the initiators and owners of health care and hospitals. In some colonial settings, health care was the main domain of the government (Philippines and Malaysia), in others there was a joint responsibility and in some countries the main accent was with private parties.

The type of health care in the colonial situation, often mirrored the metropolitan type. As during the $19^{\text {th }}$ century differentiation took place in most countries, especially in France, the USA and Great Britain, specialized hospitals grew in number and kind in these countries. This development was imitated in the colonial situation, where a large expansion of specialist hospitals took place as well: hospitals for psychiatry, leprosy, beriberi, syphilis, eye diseases, convalescent homes, etc.

Compared to American, French and British hospitals, Dutch hospitals were rather slow in achieving modernization during the greater part of the $19^{\text {th }}$ century. Towards the end of the century, an extensive programme of building new hospitals was on its way. Following the examples of Boston, Paris and London, the architecture was predominantly the pavilionsystem. This style of hospital architecture was promoted even more strongly when the Law against contagious diseases of 1872 obliged municipalities in The Netherlands to arrange for separate units to nurse infectious diseases. The hospitals in The Netherlands were mainly established in the larger towns and cities and, although some efforts were made to introduce small rural hospitals, these initiatives soon proved to be too costly. The Dutch Medical Society (NMG) considered that the minimum capacity of a hospital should be 100 beds. In the meantime, about 20 small rural hospitals had been established by private or company initiatives, but did not survive for long. ${ }^{32}$

The organization and financing of hospital care, was in the hands of private foundations such as Diaconessenhuizen and Roman Catholic hospitals, who took the lead in initiating the establishment of modern hospitals. There were some public hospitals in larger towns and cities, which were founded by municipalities and there were a few public teaching

32 H. Van der Velden, Financiële toegankelijkheid tot gezondheidszorg in Nederland 1850-1941 Transl.: Financial accessibility of Health Care in the Netherlands (Amsterdam 1993) 72-77. 
hospitals, but by 1920 their number (39) was small compared to the number of private hospitals (214). ${ }^{33}$ Compared to the beginning of the $19^{\text {th }}$ century, the number of hospital admissions grew from 1 per 1,000 inhabitants to 6.5 per 1,000 by the end of the century and the number of hospitals from 20 to $108 .{ }^{34}$

Returning to the situation of the Netherlands Indies at the turn of the century, one may classify the greater part of the Inlandsche ziekeninrichtingen (Indigenous hospitals) in the category general public hospitals with a small capacity, on average, 10 - 40 beds. The NI Government usually provided for staffing and finances. There was little or no qualified nursing care, except for the situation in some Diaconessenhuizen and other private charity initiatives. The number of medical specialists was very limited. In most cases, there was one physician or dokter-djawa providing medical interventions. The pavilion-type of hospital was everywhere propagated as being most appropriate for the tropical environment. Especially, since this type of architecture allowed for good ventilation and prevention against infectious diseases.

The use of hospitals may be deduced from the admissions of Government hospitals. Since numbers varied due to incomplete statistics, the average of the last 5 years in the period 1890-1910 was taken. This produced a figure of 68,000, including a few missionary hospitals. ${ }^{35}$ The admission of civilian patients in military hospitals, in company hospitals and in the remaining missionary hospitals may account for at least $50 \%$ of the above figure, thus arriving at approximately 100,000 admissions by the end of the period considered. For a population of about 29.2 million, the admission rate comes to about $3.4 \%$ of the population, compared to $6.5 \%$ in the homeland.

The admission rate of hospitals in the Netherlands Indies seems rather high in view of the indigenous attitude. According to reports of physicians, the indigenous population was generally very reluctant in entrusting themselves to Western health care. This reluctance was even more pronounced when confronted with hospitals. Probably, avoidance gradually diminished as the quality of medical interventions increased. Successful treatment became known and attracted new patients, while the supply of services grew. In reports of local medical institutions, doctors and dokters-djawa made comments on either stagnation or on increasing numbers of visits. Some treatments and medicines acquired popularity, e.g. quinine pills and powders against malaria and salvarsan against syphilis and yaws. Treatments of eye diseases were also popular in specific rural areas with a high rate of eye diseases. After a long period of limited use or enforced use of health facilities, a period arrived in which new hospitals could successfully be started and find sufficient patients. It

33 In the year 1920 there were 33 Protestant and 64 other private hospitals.

34 Zondervan, De ziekenhuizen in Nederland en Indonesië in de $19^{e}$ eeuw, 38.

35 Derived from annexes of the Koloniale Verslagen of 1906-1910, called Numerieke Opgaven (Statistics). Patients treated in so-called Gouvernementsziekeninrichtingen, comprising City Dressing Stations, Chinese Hospitals, and indigenous hospitals for the poor and for syphilitic women, beriberi hospitals, and hospitals for contagious diseases. 
hardly seems to be accidental that in this period the therapeutic outcome of hospitals was strongly improving.

This successful start of new hospitals and outpatient clinics was promoted in a very effective way by three events, which occurred after 1900 in the second part of the period and which would influence the future of hospitals in a prominent manner.

The first was the Decentralization Act of 1903, which gave the opportunity for regions to gain autonomy and organize their own facilities, including health care. ${ }^{36}$ The second and most important one was the Ordinance of 6 June 1906 , regulating subsidy for private indigenous hospitals and auxiliary hospitals. ${ }^{37}$ The third influence took place in 1906, when the Reorganization Commission was appointed whose task was to prepare the separation of the military and the civil medical services. ${ }^{38}$ It appeared that the Decentralization Act would have considerable influence on hospital affairs at a later stage, while the subsidy regulations had immediate effect.

The recommendations of the Reorganization Commission would take effect from 1911, when its recommendations materialized into the new regulations of the Burgerlijke Geneeskundige Dienst (Civil Medical Service). ${ }^{39}$

\section{Survey Hospital situation 1890}

Before starting the discussion on hospitals in the new era, it is necessary to make an inventory of the hospital situation in 1890 (see Table 4). Table 4 shows the number and capacity of hospitals with respect to the size of the population and gives the limited size of the medical staff. It should be noted that the number of indigenous hospitals changed from year to year and that their capacity usually was very limited. One may assume, on average, some 10 beds per hospital. For the 36 indigenous hospitals mentioned before, this means a total capacity of some 360 beds. Concerning the five largest general hospitals on Java (two Chinese and three Stadsverbanden) the average number of occupied beds was 1,093 in 1890. There were six company hospitals (five on the Outer Islands, one on Java) with an estimated capacity of about 300 beds.

The remaining specialized hospitals, a total of 33 hospitals had together a capacity of about 2,500 beds ( 9 leprosy hospitals (223 beds), 15 hospitals for syphilis ( 150 beds), 3 beriberi hospitals (1587 beds), 3 psychiatry asylums (502 beds) and 3 convalescent centres

\footnotetext{
36 Act of 23 July 1903 (Nederlandse Staatscourant no.219; Indisch Staatsblad no.329), followed by the appointment of a "Regeringscommissaris voor de decentralisatie." (Government commissioner of decentralization).

37 Staatsblad van Nederlandsch-Indië no. 276, Regelen voor de toekenning van subsidiën uit's Lands Kas ten behoeve van particuliere Inlandsche ziekenhuizen en hulpziekenhuizen. Transl.: Rules governing the subsidies for private indigenous hospitals and auxiliary hospitals).

38 Commissie tot voorbereiding eener reorganisatie van den Burgerlijken Geneeskundigen Dienst. Transl.: Preliminary Commission concerning a reorganization of the Civil Medical Service.

39 Staatsblad van Nederlandsch-Indie van 24 December 1910, wijziging van het Reglement op den burgerlijken geneeskundigen dienst in Nederlandsch-Indië. Transl.: Amendment to the Regulations on the Civil Medical Service.
} 
(75 beds). ${ }^{40}$ Altogether, these 79 hospitals had a capacity of roughly 4,300 beds. It should be observed, that the number of European and native doctors increased substantially, compared to the situation at the end of the $18^{\text {th }}$ century when there were only 86 surgeons. The availability of civil hospital beds was 0.14 per 1000 inhabitants. By this time, there were almost the same number of military beds $(4,200)$ and as some of these beds were also available for the civilian population, the availability ratio will probably have been higher than the noted 0.14 per 1,000. For comparison: bed availability at this time amounted to 1.7 per 1000 in The Netherlands. ${ }^{41}$ Note, that the admission rate (column 6) was 1.1: more than $1 \%$ of the population on average attended a hospital once a year.

Table 4 Hospital situation NI about 1890 (military hospitals not included)

\begin{tabular}{|c|c|c|c|c|c|c|}
\hline Description & $\begin{array}{c}\text { Number } \\
\text { doctors } \\
(1)\end{array}$ & $\begin{array}{c}\text { Number } \\
\text { hospitals } \\
(2)\end{array}$ & $\begin{array}{c}\text { Number } \\
\text { beds } \\
(3)\end{array}$ & $\begin{array}{c}\text { Patients } \\
\text { Treated } \\
(4)\end{array}$ & $\begin{array}{c}\text { Population } \\
\text { numbers } \\
(5)\end{array}$ & $\begin{array}{c}\text { Ratio } \\
(4) /(5) /(6)\end{array}$ \\
\hline Java ED* & 80 & & & & & \\
\hline Java $\mathrm{DD}^{* *}$ & 68 & & & & & \\
\hline Java Total & 148 & 51 & 3,700 & 265,600 & $23,900,000$ & 1.11 \\
\hline Outer Islands ED* & 63 & & & & & \\
\hline Outer Islands DD* & 40 & & & & & \\
\hline O. Isl. Total & 103 & 28 & 600 & 82,100 & $7,800,000$ & 1.05 \\
\hline Total & 251 & 79 & 4,300 & 347,700 & $31,700,000$ & 1.1 \\
\hline
\end{tabular}

${ }^{\star}$ ED: European doctors, involving civilian physicians and military doctors who were appointed to act in favour of civilians, called Officieren van gezondheid (Health Officers). ${ }^{*}$ DD: Dokter Djawa, indigenous doctors trained at the STOVIA.

\section{The motives of the new hospital intitiators}

Before introducing the hospitals of the two decades 1890-1910, purpose and motives to establish these hospitals for the indigenous population will be discussed.

In the course of the $19^{\text {th }}$ century, the NI government established a number of specialized hospitals, though its explicit policy was to abstain from providing hospital care to individuals. Several examples of these institutions were discussed, varying from psychiatric hospitals, hospitals for syphilitic patients to leprosy institutions. They had in common that the government and health authorities preferred to have these patients separated from the community, as they might cause a risk for other people. These hospitals continued to exist during the period this chapter discusses.

From 1890 -1910 new initiatives were taken by plantation owners, missionary societies and deaconess societies. The latter two groups founded hospitals out of charity motives. These

40 The three psychiatry asylums (502 beds) are mentioned in the Koloniaal Verslag 1891 Annex DD.

41 Zondervan, De ziekenhuizen in NOI, 27. 
were mostly general hospitals, though a few specialized hospitals were established as well. The first group, the plantation estate owners, faced the same problems the VOC had met: their workers were in a very poor health condition and many died, which meant that they had to recruit new workers from abroad. Their motive to found hospitals was an economic one: they wanted to save money by keeping their workforce healthy and alive. For the NI government a new motive came up: the ethical policy, adopted by 1900, which led to initiatives to found new civil hospitals or to expand and rebuild old ones. Moreover, it resulted in measures to promote the initiatives of other actors in the hospital field.

Looking at the old and new actors of this period, the situation may be evaluated thus: from 1890 there was a hesitant start of new missionary hospitals, a rather strong manifestation of company hospitals and from about 1900 a strong increase in new government hospitals (see the paragraphs on these categories hereafter).

\section{Hospital Architecture}

Different types of hospital architecture have already been discussed. After the Hofbouw and the Corridor system had been applied, the Pavilion system became popular in Europe, at least for some time in the $19^{\text {th }}$ century. However, this type of architecture had a few disadvantages in Western countries. It soon appeared that pavilion-hospitals required too much space, were too costly and with the hospital organization growing, proved to be very time-consuming. The rather long distances that hospital employees had to bridge from one department to another appeared to be very inefficient. Houwaart mentions as a notorious example the Hôpital Edouard Herriot that was opened in 1913: a hospital of 3,000 beds in which the distances between departments sometimes exceeded 2 kilometers and this became an example of how the pavilion hospital had outlived its usefulness. ${ }^{42}$

Nevertheless, in the Netherlands Indies the pavilion model remained successful and continued to be appropriate for the tropical situation. This is not the place for an extensive elaboration on building programmes, but in the next paragraph we will encounter a more specific hospital building programme for the plantation belt of Sumatra.

\section{Outpatient Departments}

Common to all types of hospitals at the end of the $19^{\text {th }}$ century was the organization of one or more outpatient departments. In present times an outpatient department is a department of a hospital, visited by patients who want to consult a doctor or have a doctor perform small medical interventions without being hospitalized. The doctor utilizes the technical and administrative facilities of the hospital.

42 Houwaart, De ontwikkeling van het ziekenhuis in de moderne tijd, 332-333. 
Initially, outpatient contacts in the NI had many forms: from visits of outposts (sometimes with the first objective of having periodical checks on prostitutes), to an open door of the physician's house or a building designated for that purpose and either connected with a hospital or established somewhere else. The phenomenon as such started in the Netherlands Indies more or less at the beginning of the $20^{\text {th }}$ century and had a fast development. (See Figure 4).

In 1902, the Annual Report of the Civil Medical Service describes 76 locations on Java and Madoera, where indigenous patients could have medical consultations and treatment. In some cases, the number of consultations was specified, but often indications such as: "the outpatient department took many visitors" or "the outpatient department was badly visited" substituted figures. The quality of the treatment was questioned by some reporters (Inspectors of the Civil Medical Service or health officers). We may take the comment of one of them as illustrative for the situation in one of the departments of Western Borneo, the under-department Lara and Loemar. The report mentions that the health officer took care to visit patients in the kampong or on the passer (market), when they were unable to appear in person. The number of patients visiting the outpatient departments varied considerably, between none to 20 . The nature of the treatment differed greatly compared to European outpatient departments. Very often the patient only asked for worm powders, quinine, castor-oil, etc., and did not pay attention to medical advice. If the treatment took too long in his view or did not take effect in due course, the patient stayed away and disposed of his bandages. He decided to manage his health himself, if necessary with the help of traditional medicine. The inspector mentioned that lately the confidence of the Dajak people was growing, especially when surgical interventions and treatment of wounds were needed. But there were still cases in which a Dajak initially spent a large amount on Chinese medicine before taking to a European kind of medical assistance. ${ }^{43}$

The 1902 annual report mentioned a variety of problems that asked for medical assistance, such as eye problems (conjunctivitis, trachoma), skin diseases (ulcers, yaws, and scabies), fevers, beriberi and venereal diseases. The course of outpatient development over the years 1890-1910 period may be tracked by the following data: The total number of consultations for 1902 on Java and the Outer Provinces was 79,800 for 47 outpatient departments and for 1909: 239,300 for 67 outpatient departments. In 1902 there were many more outpatient departments than accounted for (Next to the 47 that produced statistical data, there were an additional 75 without figures, but with some evaluation of results) ${ }^{44}$.

In 1909 some indication was given for an additional 26 outpatient departments. The number of consultations reported for Java doubled in this period (1909 compared to 1902). In the Outer Provinces the number grew tenfold: from 8,800 to 98,000. The 1909 annual report

43 J. Haga, "Eenige statistische en andere gegevens over het jaar 1902", GTNI 43 (1903) 773-774.

44 Such as" a growing number", "not many patients", "a varying number of visitors", etc. 
of the Civil Medical Service mentioned a strong increase in the number of outpatient visits at a diminished number of locations on Java and Madoera (64). ${ }^{45}$

Examining the reports on the health of the population in the years after 1902, it should be noted that not only the number of outpatient departments increased, but the number of hospitals as well. This increase of the number of hospitals will be elaborated later on, but already on the basis of the figures presented for outpatient departments, we may conclude that the indigenous population increasingly sought western health care.

\section{DECREASING IMPORTANCE OF MILITARY HOSPITALS}

In the period discussed in this chapter, the last skirmishes took place between the Civil Medical Service (CMS) and the Military Medical Service (MMS). The chief of the MMS still remained chief of the CMS as well, but there was quite some nibbling away at his realm. This was mirrored by the Geneeskundig Tijdschrift voor Nederlandsch-Indië (GTNI), in which many articles about military medical achievements were published and the vast number of medical statistical data appeared under the name of "Summier Ziekenrapport" (Summary Patient Report). ${ }^{46}$ In this same Review, a systematic survey of civilian patients and civil hospitals was absent.

From 1902, this changed and vast surveys appeared with the veiled title "Some Statistical data derived from the Civil Medical Accounts". In 1909, the 'some' had already extended to 75 pages for Java and 115 for the Outer Provinces. The "Summier Ziekenrapport" of the MMS quietly disappeared from the pages of the GTNI.

\section{Personnel}

Nevertheless, in 1890 the CMS still heavily depended upon the health officers of the MMS (see Figure 5). This Figure reflects the growth of the number of doctors in the period 1890 -1910 and the proportion of civilian and military doctors. It is clear that the initial predominance of the military gradually gives way to civilians. In 1890, almost $50 \%$ of the physicians (62 health officers out of a total of 130 doctors) were provided by the army. In the next 20 years this percentage dropped to $22 \%$ (45 out of 209). The total number of European physicians grew by $80 \%$, while the number of European military doctors only increased by $35 \%$. Counting the total capacity available for the civilian population and excluding the health officers, the growth amounts to $140 \%$ : from 68 civilians to 164 . Apparent is the large rise in the number of private physicians. As to the dokters djawa: their number rose from 108 in 1890 (see Table 4) to 148 in 1910.

45 Account should be taken for the varying number of incoming statistics. Some residencies reported faithfully every year, but reports from other residencies were received on an irregular base.

46 GTNI: Geneeskundig Tijdschrift voor Nederlandsch-Indië (Medical Review of the Netherlands Indies). 


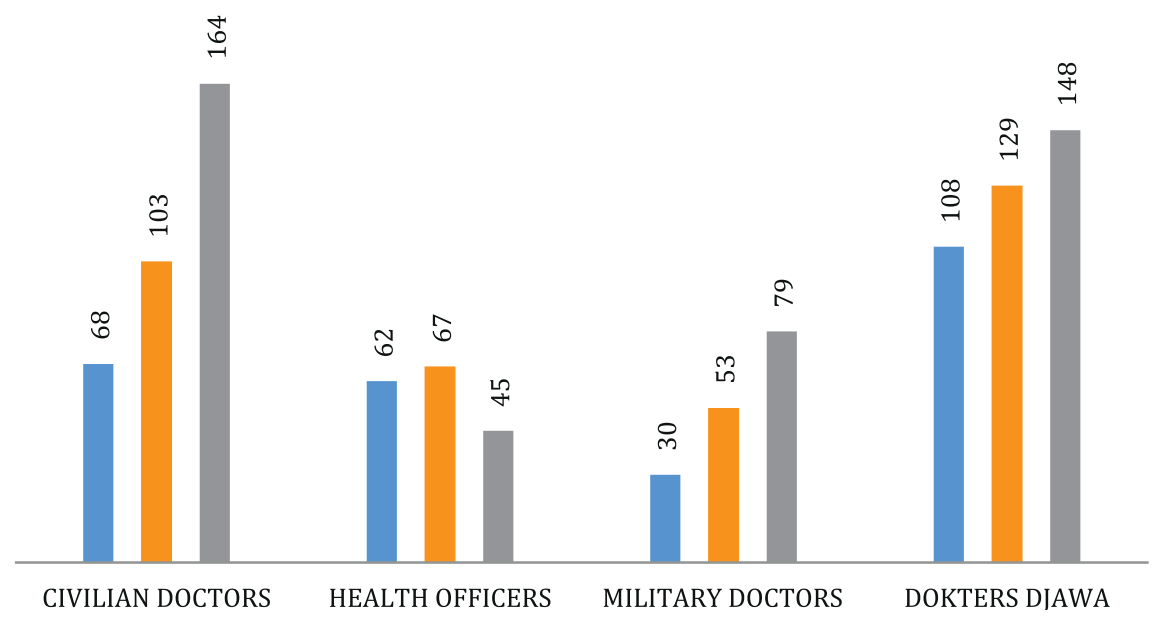

Figure 5 Medical personnel 1890-1910 ( Source: Regeeringsalmanak, part 2, years 1891, 1901 and 1911.)

\section{Distribution and capacity military hospitals}

It is hard to find any figures about military hospitals. From the descriptions of Schoute we know that there were three categories of curative facilities: the large military hospitals, the garrison hospitals and the infirmaries. Within these categories of hospitals classes were distinguished depending on the average number of occupied beds. The last complete survey made on the request of the Dutch government dates from 1867 (see chapter 3, Table 2). At that time, about 4,200 beds were scattered over 79 locations, most of them lying in the Outer Provinces, where a large number of military expeditions took place in the last three decades of the 19 th century.

The military expeditions led to considerable loss of life, not only as a consequence of combat, but equally due to the most feared disease: beriberi. Usually only a small number of Europeans incurred this disease. The largest number of beriberi victims was among the convicts, followed by the indigenous soldiers. In many cases, evacuation to Padang or to the highlands near Padang made all the difference to the sick soldiers and convicts. The same held true when the beriberi patients were sent to recover on Java.

The distribution of military hospitals and their capacity in the year 1890 is given in Table 5. Comparing Tables 2 and 5, it can be seen that the largest difference is in the number of occupied beds with a reduction of some $25 \%$. The cause of this reduction is to be found with the main military hospitals in the three large cities of Java: Batavia (Weltevreden), Semarang and Soerabaja. The combined use of military hospital beds in these cities diminished in 25 years from 1,601 to 691. Later, when inspecting the general civil hospitals of Java, we will see what came in its place. 
Table 5 Military hospitals 1890

\begin{tabular}{lcccccc}
\hline Category & \multicolumn{2}{c}{ Java } & \multicolumn{2}{c}{ Outer Provinces } & \multicolumn{2}{c}{ Total } \\
\hline Hospitals/ Beds & Number & Beds & Number & Beds & Number & Beds \\
\hline Military hospitals & 3 & 691 & 0 & 0 & 3 & 691 \\
Garrison hospitals & 14 & 1,106 & 15 & 1,085 & 29 & 2,191 \\
Infirmaries & 9 & 40 & 44 & 256 & 53 & 296 \\
\hline Total & $\mathbf{2 6}$ & $\mathbf{1 , 8 3 7}$ & $\mathbf{5 9}$ & $\mathbf{1 , 3 4 1}$ & $\mathbf{8 5}$ & $\mathbf{3 , 1 7 8}$ \\
\hline
\end{tabular}

Source: Koloniaal Verslag 1891, Appendix D, III

In 1910, a new kind of survey gave the distribution of personnel and of hospitals for each Regency. On Java there was a total of 8 military hospitals and for the Outer Provinces 14. This means that the number of hospitals (Main hospitals and garrison hospitals taken together) diminished from 32 to 22. Apparently, Java lost the most hospitals (from 17 to 8). The number of garrison hospitals located on Sumatra decreased from 8 to 6 , while those situated in Atjeh increased from 1 to 5, on Borneo from 2 to 4, on Celebes from 1 to 3. Hostilities and military expeditions in these regions accounted for the increase.

\section{Architecture}

Schoute gives us some characteristics about the appearance of the three main military hospitals, derived from descriptions by Kiewiet de Jonge ${ }^{47}$ who visited the hospitals around 1890:

The military hospital at Batavia (Weltevreden) ... had been built according to the pavilion design, a hospital architecture that had not yet been introduced in Europe. It had a good reputation, though from time to time it was harassed by bed bugs. Passing the gate one came into a large garden, in which to the left and to the right the rooms for first class patients were located. The hospital had a capacity of 500-600 beds, though in the years of beriberi, especially 1885, 1886 and 1887 sometimes as much as 1,000 patients were nursed. ${ }^{48}$

The military hospital at Soerabaja was situated on the large river Simpang. It had the shape of a horseshoe. Both the legs of the horseshoe housed the administration, pharmacy, stores, doctor's room and conference room. The central building housed the wards in two storeys. In the upper floor the patients were placed who had venereal diseases. Behind the main building in the garden connected by corridors, was located a ward for sick women. At the other side, there was a ward for officers. There was a so-called blokzaal for the nursing of punished persons. The building as a whole was poorly furnished; the wards in the main building did not meet the needs and had poor ventilation. Here too one suffered from bed

47 G.W. Kiewiet de Jonge was at that time teacher at the Stovia, the school for dokters djawa.

48 Translated by author. 
bugs that nested in beds, lying mats and straw mattresses. The garden behind the building was enormously large and continued to the river: a bell was sounded when the cholera boat arrived with patients from the roads or from the lower town. (See Figure 6)

The military hospital at Semarang had been designed to house 150 to 200 patients. It was situated in the town centre, next to the City Dressing Station. This hospital had also two storeys and was situated in a large garden. It resembled the hospitals of Weltevreden and Soerabaja, but on a smaller scale.

\section{Research and education}

The role and influence of the MMS on the health conditions in the Netherlands Indies was not only manifest in terms of hospital capacity and manpower, but also in the fields of medical training and research. A famous example was the large-scale research project to look into the causes and possible therapy for beriberi, the disease that ravaged large parts of the army. The Utrecht pathologist C.A. Pekelharing and the neurologist C. Winkler received this assignment from the Dutch Government and started their research in Atjeh and the Padang Highlands. They cultivated bacteria from the blood samples taken from the victims. They concluded that the bacteria flourished in the air in the barracks and that by purifying the air should diminish the affliction. Unfortunately, this proved to be wrong. The laboratory they used was located in the military hospital at Weltevreden and was provided with the long name: "Laboratorium voor onderzoekingen op het gebied der Pathologische Anatomie en Bacteriologie". ${ }^{49}$ In 1888, after the departure of the two Dutch scientists, Chr. Eijkman was appointed director of this laboratory. In 1890 he published his famous article in the GTNI "Polyneuritis with poultry". This became the base for the theory of avitaminose, later developed by his successor G. Grijns and responsible for a conclusive answer to beriberi..$^{50}$

The military hospital at Weltevreden placed the cornerstones for the education of indigenous doctors and for fundamental laboratory research, by housing respectively the STOVIA and the laboratory that discovered the cause of beriberi. ${ }^{51}$

\section{The impact of the military hospitals in the Netherlands Indies}

During a large part of the $19^{\text {th }}$ century the military dominated health care. This was the case in the field of personnel, of number of hospitals and their quality. It was also visible in facilities for training and for scientific research. The civil hospitals played in these fields an insignificant role. Towards the end of the $19^{\text {th }}$ century, the military role in health care changed, which was most noticeable in the available professionals.

\footnotetext{
49 Laboratory for investigations in the field of pathological anatomy and bacteriology.

50 B.C.P. Jansen, Het levenswerk van Christiaan Eijkman 1858-1930 Transl.: The life's work of Eijkman (Haarlem 1959).

51 STOVIA = School Tot Opleiding Van Inlandse Artsen (Training School for indigenous doctors).
} 


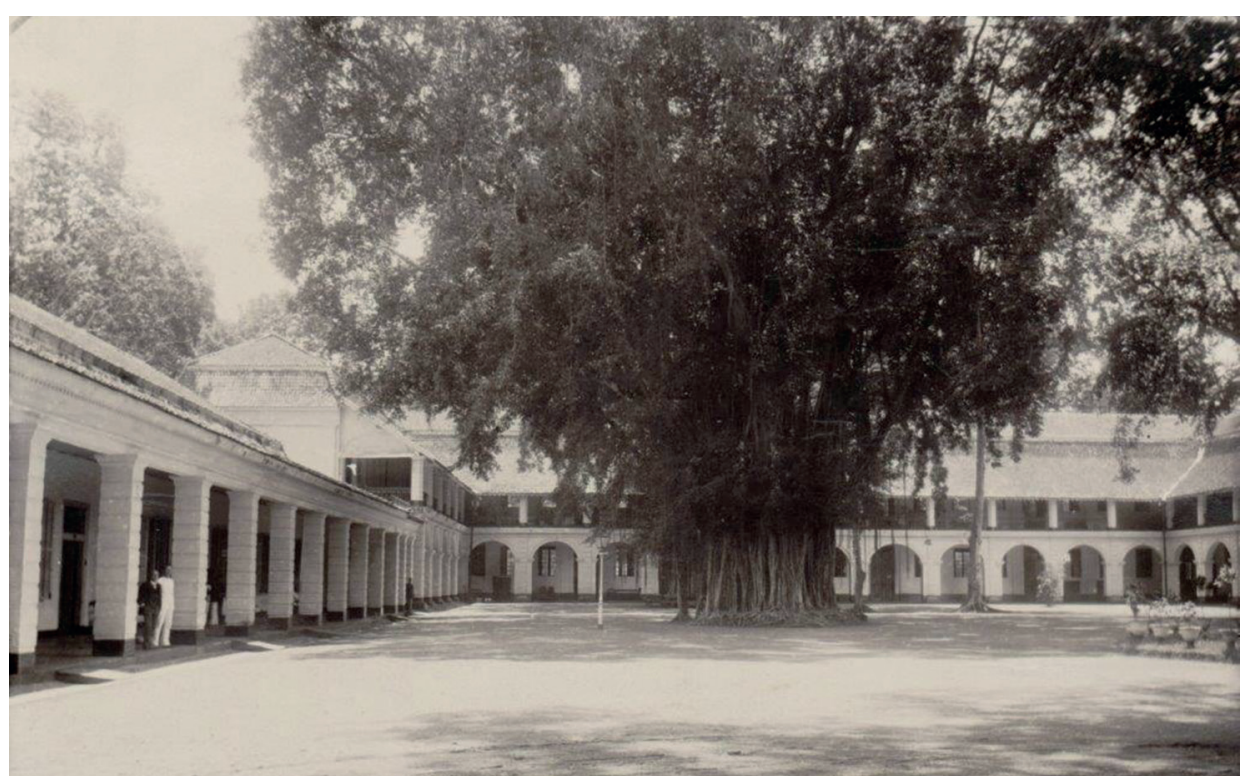

Figure 6 The military hospital at Soerabaja (Source: KITLV)

Figure 5 depicted the situation in 1890, when there were 92 military doctors. Their number decreased in the preceding 40 years from 121 to 92 . Yet, 62 of them were still engaged in civil health care as health officers. In 1890, the CMS employed 68 civil doctors. Forty years before, the number was only 11. By 1910, the number of civil doctors outnumbered the military: 164 compared to 124 .

The budget available to the MMS and the CMS proved to be similar. By 1910, the real expenditure for the MMS was about $f 2.2$ million, while the CMS held $f 3.3$ million. Twenty years before, the expenditure of both was almost the same: $f 1.8$ million for the CMS and $f 1.9$ million for the MMS. ${ }^{52}$

\section{GENERAL HOSPITALS FOR CIVILIANS}

In the preceding paragraph we have seen that little by little the military hospitals paved the way for the hospitals of the CMS to take over. From 1890 to 1910, the number of military hospitals on Java was reduced by half, from 17 to 8 . Prior to 1890 the capacity used had already gone down by $25 \%$. However, these figures refer to military beds and capacity for the military. Probably, only a small part of this capacity was available for civilian patients.

52 Resp. Begrooting van Nederlandsch Indië voor 1894 en voor 1914 en werkelijke uitgaven in 1889-1892 en 1906-1910, in: Handelingen Tweede Kamer der Staten-Generaal (Parliamentary Proceedings 1894 and 1914, including real expenditure for the period 1889-1892 and for the years 1906-1910). 
Therefore, it is interesting to look into the non-military institutions that were newly founded and became available for the indigenous population.

The general civil hospitals in 1890-1910 may be divided into three main categories, alternatively depending on economic, political and cultural developments of the time. They will be discussed in the following sequence:

1. Public hospitals: Political developments (ethical policy) transformed the health policy of the NI government towards an active and stimulating role regarding hospitals. New government hospitals were founded and old ones were renovated or rebuilt, mainly on Java;

2. Charity hospitals: Political, religious and social motives inspired the establishment of missionary hospitals, deaconess hospitals and charity hospitals of other private parties.

3. Company hospitals: Economic developments paved the way for company hospitals, which were established in areas, where new enterprises settled. Plantations, mining companies and oil explorations started on Sumatra and the nearby islands Bangka and Billiton and on Borneo. Private enterprise took place on Java, but did not immediately lead to initiatives to found hospitals.

\section{Public General hospitals}

Three so-called City Dressing Stations and two Chinese hospitals functioned on Java during the $19^{\text {th }}$ century. One Chinese hospital, at Batavia, existed from the $17^{\text {th }}$ century. The three City Dressing Stations were the main general government hospitals not only for Java, but also for the whole of the Netherlands Indies.

Inspector Kiewiet de Jonge who gave his account on the military hospitals, commented on the quality of the City Dressing Station in the year 1890: "The City Dressing Station at Batavia, situated in a place called Glodok, is an institution to which convicts, prostitutes and tramps are taken by force. Nobody would dream to enter there out of free will. It is a miserable building of which the floors, made of smooth blue flagstones, are the only good thing about it. The remaining parts of the complex are made of bamboo and the place is overrun with wall-bugs. The city doctor in charge feels so embarrassed by the situation that he will never guide someone around in the building. Of course there will be improvements from time to time, but these measures cannot alter the fact that the hospital remains by far insufficient." Kiewiet de Jonge visited the other CMS hospitals too and his judgment on these hospitals was also negative. ${ }^{53}$ As a result of his visit, the restoration of the Batavia City Dressing Station was announced. However, this decision was revised after some years and was reduced to having some buildings added to the complex in the same compound. It would take 25 years more, before the building of a new Centrale Burgerlijke Ziekeninrichting at Salemba was assigned to the architect $\mathrm{H}$. von Essen.

53 Schoute, "De Geneeskunde in NI", GTNI 75 (1935)1469. 


\section{Personnel}

Some years before the visit of Kiewiet de Jonge, Governor-General J.W. van Lansberge (1875-1881) decided how the City Dressing Station at Batavia should be run. In 1879 he gave the number and quality of the personnel that could be appointed and which salaries they should earn:

1 opziener administrateur (head of administration), earning $f 120$ monthly.

2 ziekenvaders (male supervisors), earning each $f 50$ monthly.

10 mannelijke bedienden (male servants) on $f 15$ monthly each.

1 male servant extra per each 20 patients above the number of 200.

4 vrouwelijke bedienden (female servants) on $f 12$ monthly each.

1 inlandse verbandmeester (supervisor first-aid) on $f 30$ monthly.

1 inlandse hulpverbandmeester (second in charge first-aid) on $f 20$ monthly.

1 cook on $f 15$ monthly. ${ }^{54}$

The budget for hospital workers totalled about $f 6000$ per year. The number of admissions in that year (1879) was 5,688. The average number of inpatients was 650 , of whom $65 \%$ were convicts (421). Almost thirty years later, in 1908, Governor-General J.B. van Heutsz (1904-1909) issued a budget for each category of staff. For the City Dressing Station of Semarang and the Auxiliary Dressing Station, the budget totalled $f$ 10,284 per year, half of which was assigned to the nursing personnel..$^{55}$

\section{Patients}

From 1902 a new series of statistics was published by the Civil Medical Service. ${ }^{56}$ When discussing the outpatient departments of the new century, it was found, that the number of outpatient visits had substantially increased during the first decade of the $20^{\text {th }}$ century. The development of the five main hospitals is compared for 1890-1910 (see Figure 7). The number of admissions and the average number of occupied beds are presented for the beginning of the period (1890), about the middle of the period (1899) and at the end of this period (1910). The figures for 1899 demonstrate a $40 \%$ decline in occupied beds and admissions, compared to 1890. In 1910, this decline had been reversed, but this was partly due to the circumstance that the auxiliary Stadsverband of Semarang joined the ranks. One can speculate on the reasons of the temporary decline. Possibly the founding of new hospitals in the neighbourhood could explain this development. In Batavia as well as Soerabaja, Deaconess hospitals had been built, which made use of qualified nurses.

\footnotetext{
54 Staatsblad no. 18 van 21 Januari 1879. Besluit no. 4 GG van 13 Januari 1879. (Statutebook 18 of $21^{\text {st }}$ January 1879, Decision of the Governor-General).

55 Staatsblad no. 64 van 28 Januari 1908. Besluit no. 17 GG van 22 Januari 1908 (Statutebook 64 of 28 January 1908, Decision Governor-General of 22 January 1908).

56 Separate publications on Java and on the Outer Provinces were published: Civiel-geneeskundige statistische gegevens over Java en de Buitenbezittingen, 1902- 1909.
} 
Both of these hospitals also opened outpatient departments and might therefore in any case have skimmed some of the paying and voluntary patients.

It would be interesting to find an indication for which afflictions patients were treated in these years. It would be useful to find an answer to the question whether the involuntary character of hospitalization in the past, still applied to the inpatients and to what degree. Unfortunately, the only information given in the successive Koloniale Verslagen concerns the maxim, that only the sick or wounded and destitute indigenous persons would be admitted, while their likes that were not needy could be admitted as paying guests.

Apart from the City Dressing Station, Chinese Hospitals and Deaconess Hospitals there were quite a few Inlandsche (indigenous) hospitals that obtained recognition from the government. This recognition meant that they could be treated as public hospitals (Gouvernements Burgerlijke Ziekenhuizen) or be accepted as subsidized institution and their personnel accepted as public servants. In both cases, the public administrative officer (Resident or Assistant-Resident) was asked for his opinion as to the necessity of the facility. One of the appendices of the Reorganisation Report sums up the inlandsche ziekeninrichtingen for the year 1906 and arrives at 92 for 17 Residencies of Java. In general, the personnel of inlandsche ziekeninrichtingen were to look after small rural hospitals with 10 to 40 patients. Such hospitals could not only be found on Java, but in the Outer Provinces as well. An example of such a hospital in the Outer Provinces is the Civiel Ziekengesticht at Menado (see Figure 8).

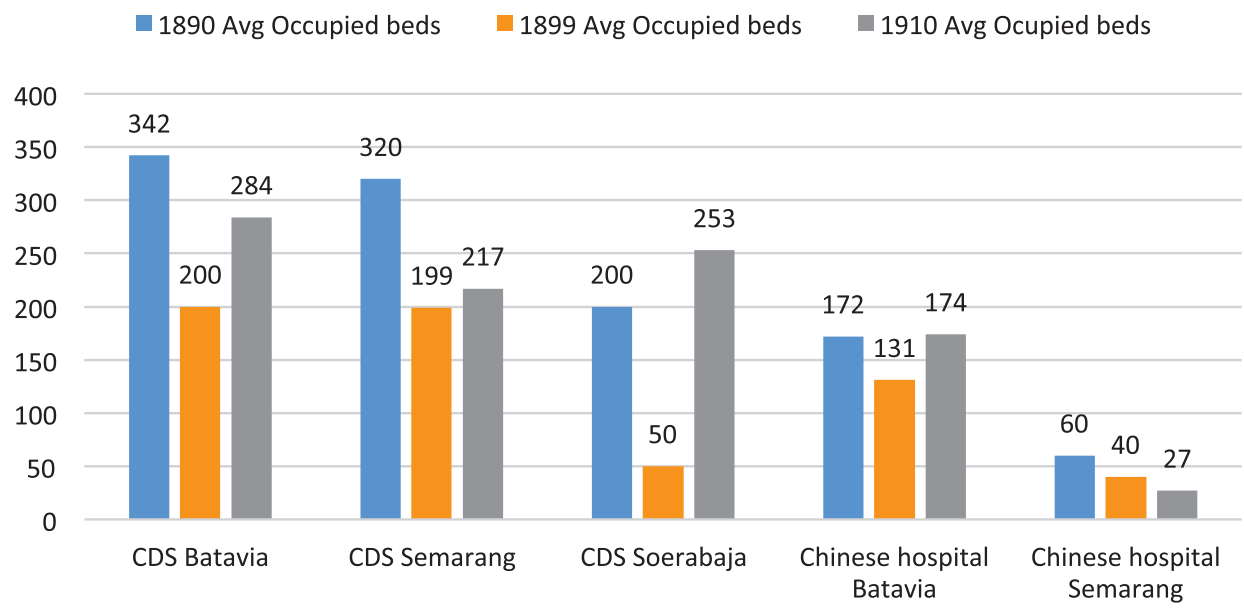

Figure 7 Use of hospital beds in the main cities of Java (Source: Koloniale Verslagen 1891, 1900 and 1911) 


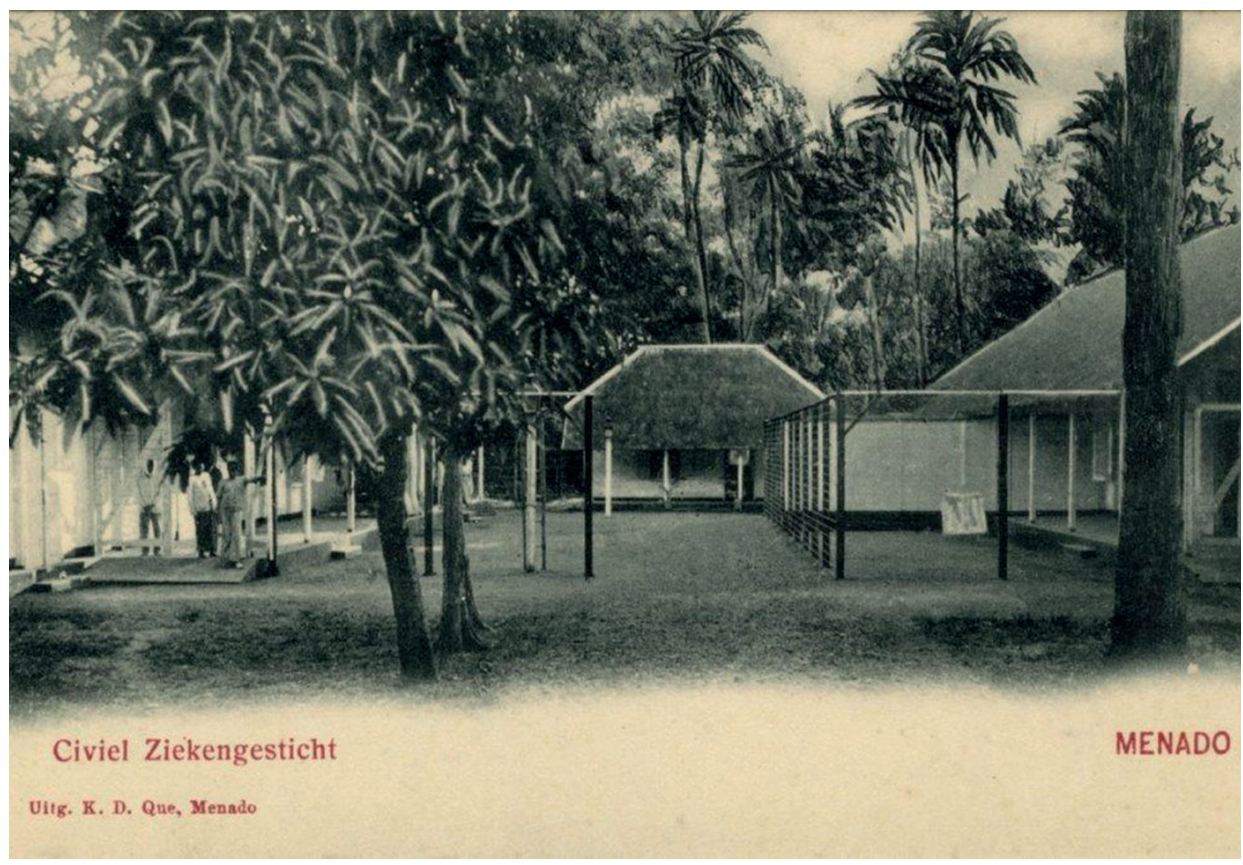

Figure 8 Civil Hospital Menado, 1900 (Source: KITLV)

\section{Finances}

In 1906, the Government of the Netherlands Indies issued regulations to subsidize private indigenous hospitals and auxiliary hospitals. These regulations were signed by GovernorGeneral, J.B. van Heutsz. ${ }^{57}$ Most hospitals for indigenous patients were actually government hospitals in which the staff was appointed by a representative of the government. Owing to the ethical turn in politics, regulations were issued to subsidize the remainder of small or medium-sized country hospitals. The regulations distinguished between 5 classes of hospitals by their capacity: class 1 applied to the very small hospitals of 10 to 25 beds, while class 5 referred to the big ones of more than 170 beds. There was also a distinction between hospitals (in which a doctor was in charge) and hulpziekenhuizen (auxiliary hospitals) in which a doctor or a dokter djawa was available as supervisor without being obliged to reside permanently on the hospital premises. From 1906, hospitals could apply for subsidy. In order to meet the subsidy conditions, they were scrutinized. To be eligible for subsidy, the head of the local administration had to declare that the community was in need of such a

57 Staatsblad van Nederlandsch Indië no. 276 of 6th June 1906, Regelen voor de toekenning van subsidiën uit 's Lands kas ten behoeve van particuliere Inlandsche ziekenhuizen en hulpziekenhuizen (NI Statutebook, Subsidy Regulations for private indigenous hospitals and auxiliary hospitals). 
facility. Besides, the regional and local administrators (Residents and Assistant-Residents) had the duty and responsibility to look after the quality of buildings, personnel, equipment and nourishment of patients. ${ }^{58}$ Another condition was that the founding association or corporation should not focus on profit. There were also clauses concerning inspection and annual reporting. The largest hospital could initially receive an amount of $f 8,500$ for the building, and a once-only grant of $f 3,000$ for the inventory. When a hospital could not get a lease for renting hospital premises, a grant of $2 / 3$ was given for the costs in acquiring the building site. These amounts were granted once-only. The subsidy on annual expenditure depended on the circumstances, whether the hospital used European doctors and nurses or indigenous employees. In the former case, the subsidy amounted to a maximum of $f 4,200$ for salaries of doctors (2 doctors), a maximum of $f 3,000$ for European nurses (5), $f 1,800$ for servants (15), $f 3,000$ for running costs, $f 420$ for maintenance of the building $(5 \%)$ and $f 300$ for maintenance of the inventory (10\%). Adding all annual subsidies together, a maximum subsidy of approximately $f 13,000$ could be given, but usually the subsidy was calculated on a much lower level.

\section{Architecture}

In 1903, the Director of Public Works, H.P. Mensinga, issued a model for a building programme of a 120-bed indigenous hospital. Part of the budget of the department of Public Works was allocated to public buildings such as hospitals. The model was created for an average hospital, which counted 100 sick prostitutes and 18 badly wounded or poor severely sick local people or employees of the police who could not be nursed at home..$^{59}$ Such a hospital did not admit any convicts or prisoners, because the urban facilities should be large enough to contain a local prison that could take care of the prisoners itself. The missing 2 beds were for temporary nursing of 2 insane persons or 2 infected patients who needed isolation. There is no reference to other hospitals in the tropics or to literature about contemporary hospital architecture. Probably the director was a man of practice, who had looked at existing indigenous hospitals on Java. This may explain why so many beds were assigned to sick prostitutes. There were separate institutions for leprosy, but the incidence of insanity or isolation cases apparently did not surpass $2 \%$ of the planned capacity. ${ }^{60}$

58 Bijblad op het Staatsblad van Nederlandsch Indie no. 6037, letter of 26th April 1904, Toezicht op de ziekeninrichtingen (Supplement NI Statutebook on supervision of hospitals).

59 The 'Normaal project voor de bouw van inlandsche ziekeninrichtingen' (Norms for building a standard indigenous hospital) apparently assumed that such a hospital counted, on average, a 100 sick prostitutes and 18 badly wounded or poor severely sick local people or employees of the police who could not be nursed at home.

60 Chapter VI of the Reorganization Report mentions a number of shortcomings of this so-called "normaal project": it does not take into account local needs and differences in the type of users. Besides it does not make provisions for future need of expansions and it should allow for medical inspection before the new buildings are opened and used. 
For smaller hospitals the model was adjusted, taking into consideration that in any institution there should be at least:

1 or more wards for sick prostitutes;

1 or more male wards

1 or more wards for women and children

1 examination room

1 operation room

1 section-room and mortuary

1 main building with entrance, pharmacy, stores for medicines, for food and inventory and rooms for the supervisors;

1 bathing place (stone pit with border and walls) and a brick hip-bath

1 latrine, if possible above running water

2 small covered places for bathing and latrine of personnel

1 kitchen with food storage

1 separate small building for patients to be isolated

1 small stone building for isolation of insane patients

\section{Terrain and buildings}

Conditions were formulated for the terrain: the hospital should be situated outside the European and Chinese quarters in order to avoid disfigurement of the environment by ugly bamboo buildings. The hospital buildings should be established in a surrounding marked by similar buildings. The terrain should be enclosed by a fence of barbed wire and the same should apply to the departments for sick prostitutes, who were separated from the rest. This condition resembles that of Europe, where hospitals were situated preferably on the outskirts of towns to avoid annoyance to citizens.

Apart from the principal posts, which were made of teak and placed in a cement footing, all remaining parts of the building, like window-frames, jambs and sheds were made of bamboo. The roofs were covered with indigenous tiles. Only in the bathrooms and the stores galvanized roofing could be used. There were elaborate instructions on how to construct water-conducts, latrines and bathing facilities. In the wards for sick prostitutes, mutually connecting bamboo bale-bales should be placed in order to facilitate the cleaning. ${ }^{61}$ These wards were required to have wooden beds, like in the ward for the insane. In the other wards cribs could be placed.

The total costs of a hospital like that described might vary from $f 6,600$ to $f 9,300$, depending on the region where the construction took place and the level of the local wages.

61 Balebale: Indonesian couch. 


\section{Private Charity Hospitals}

Prior to the 1890s, the NI Government had been reluctant to allow the establishment of religious organisations. During the $19^{\text {th }}$ century, Protestant and Roman Catholic missionaries encountered problems in getting a license to settle anywhere in the NI as missionaries. The background to this attitude was that the NI government wanted to avoid trouble with Muslim communities, as the settlement of missionaries could start disputes and disturbances. This attitude had its consequences on the establishment of missionary hospitals: only a few foreign missionary organizations established hospitals on Java and Sumatra during the $19^{\text {th }}$ century.

From about 1901, when ethical politics gained influence, things changed for the better: generous subsidies became available to build schools and hospitals. ${ }^{62}$ Already during the 1890 s the attitude towards missionary activities had changed. ${ }^{63}$ In 1901, the Director of the Department of Education, Worship and Industry, J.H. Abendanon (1900-1905), issued a circular to the civil servants of the European administration in which he stressed that opposition against the work of missionaries should be ended, while these men were often useful to the indigenous population by providing education and distributing medicines. However, the government continued to be very cautious, especially concerning places where conflicts could be expected.

Nevertheless, in the 1890s two new phenomena appeared in the field of private civil hospitals: the hospitals established and run by missionaries and the hospitals run by deaconesses. The first category developed quite a number of initiatives, first on Java, later on the other islands. The number of deaconess hospitals remained small. However, this latter type of hospitals took the lead in starting professional training of nurses.

\section{The Deaconess hospitals}

A first initiative to train qualified nurses was taken in 1895 . This initiative was taken by the "Vereeniging voor ziekenverpleging in Nederlandsch-Indië" (Nursing Association of the Netherlands Indies), which started the first Diaconessenhuis (Deaconess Hospital) at Batavia in 1896 (see Figure 9). Nursing regulations of this hospital stated that nursing had to be carried out by resident nurses, preferably deaconesses, under supervision of a female director. In 1897, the Association had four qualified nurses. The responsibilities of these qualified nurses included bedside nursing and outreaching patient care. Due to the heavy demand for bedside nursing, outreaching services would become less available.

62 Ton Kappelhof, "Zending en missie in Nederlands-Indië 1798-1960”, in: De Indische school (Lessen Godsdienst en Levensbeschouwing (s.l., s.a.) Transl.: Protestant and Roman-Catholic missions in NI.

63 Gouvernementsbesluit 1 November 1889 nr. 19, Bijblad Staatsblad no.4642 (Government Decision in the Supplement of the NI Statutebook no. 4642) stated that the negative attitude of indigenous civil servants and heads of administration towards converted indigenous persons should change. 


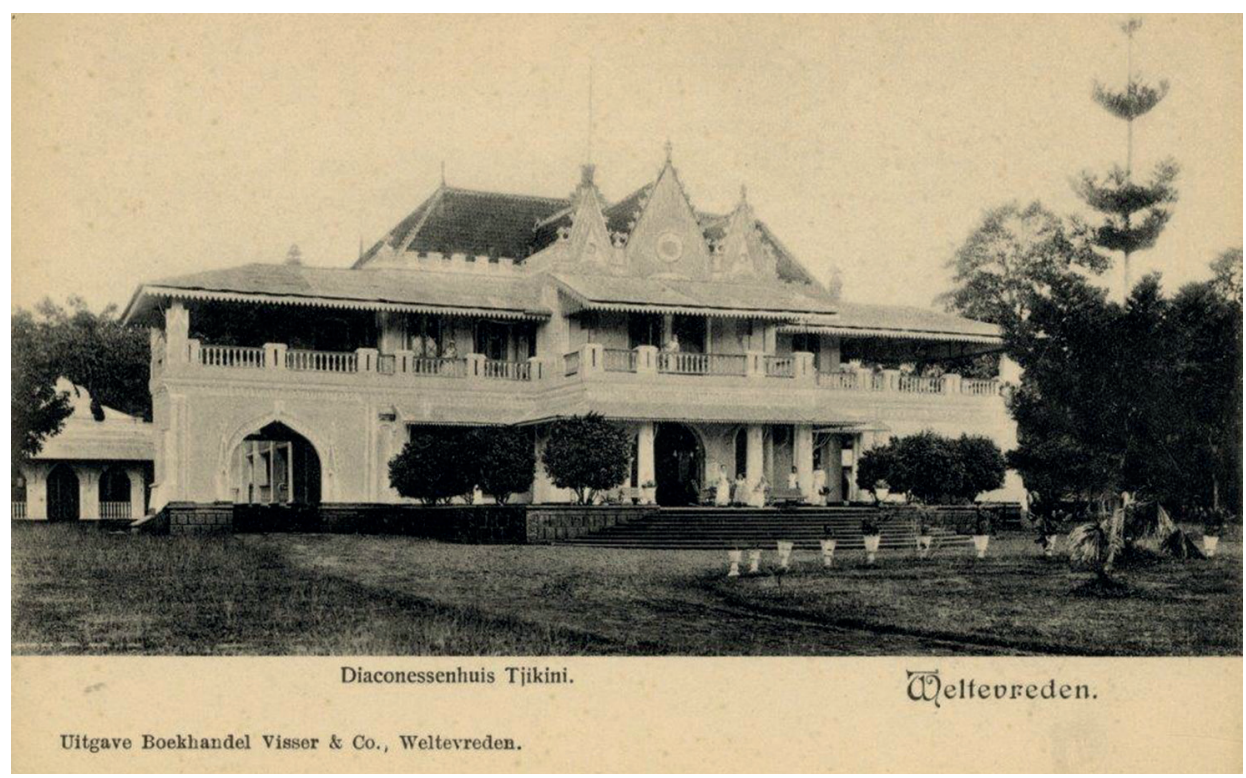

Figure 9 Diaconessenhuis Tjikini in 1896 (Source: KITLV)

The Diaconessenhuis was a charity institution based on Christian principles and provided care for people of all nationalities and all ranks. The hospital charged fees, but its services were free of charge for poor patients.

A few years later two more Diaconessenhuizen were founded: one at Soerabaja (1897) and the other at Medan (East Coast of Sumatra) in 1900. Mrs. A.J. de Graaf-Kooiman, wife of a Dutch missionary, pioneered the hospital at Batavia. She collected funds in The Netherlands and bought the mansion of Raden Saleh in the Tjikini suburb of Batavia. She received a donation of $f$ 100,000 from Queen Emma, reason to call the hospital: Queen Emma Hospital. In fact, the hospital was known by three names: Diaconessenhuis, Queen Emma Hospital or Tjikini Hospital. Several issues of the Koloniaal Verslag reported about the development of the hospital.

In 1910, the hospital trained 11 European nurses and 11 Indonesian nurses. A subsidy by the Queen Emma Fund facilitated this training. The work of the hospital was successful. Especially its outpatient department was very popular, as demonstrated by the number of patients: in 1910 the number of 1,450 outpatients seen in 11,378 consultations. The number of inpatients that year was: 758 with a total of 15,525 nursing days. There were 244 operations performed in 1910. The Diaconessenhuis Batavia still exists, under the name Protestant Gereja Indonesia Cikini Hospital. The last news about the Vereeniging Soerabaiasche Ziekenverpleging dated from 1939, when the hospital published its $43^{\text {rd }}$ annual report. 


\section{The Missionary hospitals}

The missionary hospitals often had a difficult start. By the end of the 1890s, the colonial government learnt to appreciate the initiatives of charity organizations. Little by little, the negative attitude of public servants changed and occasionally religious initiatives received some encouragement with small subsidies. The 1898 Koloniaal Verslag mentioned that many missionaries helped the population by giving medicines. The missionaries received their supply of pharmaceutical and other medical material for free from the central government stores in Batavia.

The first hospital, started by a Dutch protestant mission was situated in East Java in Modjowarno. This hospital was founded in 1894 and initially had a capacity of 60 beds. $\mathrm{H}$. Bervoets, the first director, made it available for indigenous patients only. Soon a second hospital was founded, the Petronella Hospital in Djokjakarta. This hospital had 100 beds, likewise only available for the indigenous population. The director was the missionary doctor J.C. Scheurer, who had arrived at Soerakarta, before his colleague H. Bervoets entered Modjowarno. However, the Soesoehoenan of Soerakarta did not permit establishment of a missionary complex on his territory, so Scheurer moved to Djokjakarta. The Petronella hospital he founded soon acquired fame by its innovative ideas and actions. The medical organization was arranged according to a hierarchical system of hospitals, auxiliary hospitals and outpatient clinics. Later on this system was copied by several colleagues and became known as the Djokja-system. This system resulted from the observation that in a populous area such as Djokjakarta (1.5 million inhabitants) only a portion of the population could obtain treatment in a hospital, even if the hospital counted a few hundred beds. The distances to be covered were often more than $50 \mathrm{~km}$ from the principal town.

Therefore, Western medicine had to be taken to the desa. The way to decentralize was by establishing hulpziekenhuizen (auxiliary hospitals) of about 50 beds with daily organized outpatient services. These auxiliary hospitals could assist in the fight against widespread diseases such as malaria, ulcers, trachoma, framboesia and venereal diseases. These peripheral hospitals could unburden the central hospital, which could stick to the more intensive treatments and operations. The hulpziekenhuis required a well experienced and trained nurse (with a clinical eye) to ensure that the medical and nursing activities were well organized and that the serious cases were diagnosed and referred to the main hospital. The auxiliary hospital needed to be established in the neighbourhood of a well-paved road to facilitate transportation to and from the main hospital.

This successful system was imitated by other hospitals. In a few years there was a system of 11 hulpziekenhuizen with 5 outpatient clinics, all grouped around the main hospital in Djokjakarta. From te beginning there was also criticism. Often, only hopeless cases were referred, especially in cases of childbirth the referral was too late. The results in those cases did not inspire confidence in European hospital care. Obstetrics did not gain terrain those 
years: after 10 years only 50 obstetric patients were seen each year. ${ }^{64}$

The Modjowarno hospital enjoyed confidence with the local population who had for a long time been used to live and work with missionaries. A large part of the population had been christened and became used to western medicine. Therefore, the hospital soon became too small and new buildings expanded the hospital to 280 beds. In 1900, the enlarged hospital had its subsidy doubled and appointed a second European doctor.

The more the NI government learnt to appreciate the work performed by the missionaries, the more subsidy became available, not only for the hospitals, but for the auxiliary hospitals too. The 1907 Koloniaal Verslag acknowledged this support by stating:

To the indigenous auxiliary hospitals at Ambarawa, Kalitjeret and Kedoengpendjalin (Semarang), Blora (Rembang) and Sibakapo (West Coast Sumatra), which are each under the direction of protestant missionaries of whom it is evident that they have sufficient medical knowledge, has been awarded government subsidy for the years 1905 and 1906. The statement finished with the promising remark: At Mogaredjo (Semarang), Blitar (Kediri) and Bodjonegoro (Rembang) too the protestant mission opened similar auxiliary hospitals.

Another initiative was taken in the East Java region (Residency Pasoeroean): in 1897, a 35-bed hospital had been opened. It was a hospital without a doctor, getting assistance from a neighbouring health officer. In 1899, it was moved to another town in the Residency. There is no indication what the reasons were for this move. The new town was Swaroe and the government awarded this hospital a subsidy of $f 600$ a year. From 1 July 1901 a Christian dokter-djawa was appointed to improve the medical quality of the institution.

The presence of German and Swiss missions in the Netherlands Indies has been mentioned before. The Rheinische Mission intended to start a general hospital at Moeara Sipong (WestCoast of Sumatra) and had already established a leprosy asylum at Lagoe Boti, around 1900. The government gave a subsidy of $f 1,000$ to both institutions. The leprosy hospital expanded from 30 to 60 beds. The building site for the general hospital moved to Pakantan. In 1909, a total of 4,827 patients were seen at the outpatient department in Pearadja with 30,839 consultations. Besides this hospital and the institution for leprosy, a third hospital was built in Pearadja. In both hospitals, on average, 29 patients were treated each day. A total of 230 operations were performed in that year.

64 K.P. Groot, "De medische zending in Nederlandsch-Indië" GTNI 75 (1935) (Medical Mission in NI). 
In 1910, the Koloniaal Verslag states that there were together 26 hospitals and auxiliary hospitals. 21 of them were located on Java and only 5 on the Outer Islands, 2 of them being established by the Rheinische Mission. ${ }^{65}$

\section{Private Company hospitals}

The new economic situation that emerged following the Cultuurstelsel (1870), brought about new initiatives and ultimately a new category of hospitals, hospitals established by plantation estates, mining or oil exploration companies. They are grouped as: company hospitals. At first these hospitals had rather small facilities with rudimentary equipment, but by the end of the $19^{\text {th }}$ century some of these initiatives were combined and big central hospitals were established in the period 1890-1910. By the end of 1910, some 40 hospitals had been established on Java and the other islands.

Together with the government hospitals and charity hospitals, this is the third group of general civil hospitals. In 1910, there were in this group four subgroups: Plantations, mining industry, oil industry and others.

\section{Plantations $^{66}$}

a. Initially, only a very basic facility existed at the plantations on the East Coast of Sumatra. Usually this facility was run by a Chinese or Malay healer and was visited once a week or once every two weeks by a physician. In the 1890s the smaller estate hospitals were replaced by a larger central hospital. These central plantation hospitals offered a more efficient and effective care for patients, including laboratory and transport facilities. This innovation was introduced by A. Schüffner who was appointed by one of the bigger tobacco companies. By 1910, the number of central plantation hospitals had increased to 22 and the number of doctors to 23 . The number of coolies by that time is estimated to be $170,000 .^{67}$

b. Apart from the hospitals of the plantation estates of the East Coast of Sumatra, a number of hospitals had been founded on Java for the workers of sugar, coffee and tea plantations. Generally, these were small hospitals that had no permanent doctor. Sometimes they obtained assistance from the local health officer. Most of the plantations did not have a hospital. Their workers were allowed to be taken into an indigenous government hospital, provided that there was room available and that the company guaranteed to pay the

65 The statistics presented by K.P. Groot show a somewhat different picture: 5 main hospitals, 6 auxiliary hospitals and 4 outpatient clinics. For these hospitals Groot mentions a joint capacity of 940 beds of which on average 765 were occupied. My impression is that Groot omitted some hospitals, as the author only mentions 5 towns of settlement: Modjowarno, Djokjakarta, Margoredjo, Poerwodadi and Pearadja.

66 The Koloniaal Verslag 1910 mentioned a total of 10 company hospitals on the island of Java and of 30 on the Outer Provinces. The character of these hospitals differed, some were well equipped and could take a large number of patients, but there were also small institutions that were kept alive by company support and missionary involvement. Generally, all patients that attended one of these company hospitals did not pay for their stay. Sometimes, they had to pay the medicaments received.

67 W. Kouwenaar, "De gezondheidszorg ter Oostkust van Sumatra" Transl.: "Health care on the East Coast of Sumatra" GTNI 76 (1936) 286. 
hospital bill and if necessary the funeral costs as well. ${ }^{68}$

c. On the island Banda Neira the hospital for convicts had been closed and the complex was taken over by the owners of the spice plantations (the perkeniers). The management was in the hands of the health officer, posted at Neira. Use of this hospital is only mentioned twice, namely for the years 1887 and 1888. During 1888, a number of 1,407 patients were admitted to this hospital.

d. At Pekalongan (Java) the United Sugar Companies founded a hospital. This hospital was first mentioned in the 1909 Regeeringsalmanak, mentioning the number of staff and direction. ${ }^{69}$

e. A similar initiative was carried out in 1906, in the Residency of Palembang for the Coffee Estates Pager Alam and Pasemah Estate in the sub-department Pasoemah-landen of the Palembang Residency. ${ }^{70}$

\section{Mining industry}

a. Several mining companies had their own hospitals. On Billiton the Company with the same name had two hospitals for the workers in the tin mines. One hospital was established at Manggar with a dokter djawa, the other at Tandjong Pandan with a European doctor in full-time residence. The hospital was established about $1880 .^{71}$

b. On the West Coast of Sumatra, the Ombilin Coal Mine Company founded around 1890 a large, well-equipped hospital for its miners. Figure 10 shows its operation theatre with its personnel.

c. At Sabang on the island Weh (Atjeh) the Sabang Company, a firm exploiting a coal station, founded in 1898 an infirmary for its indigenous and Chinese workers. Here too the local health officer was responsible for its management.

\section{Oil Industry}

a. In 1906, de Koninklijke Maatschappij tot exploitatie van petroleumbronnen in Nederlandsch-Indië (Royal Dutch Oil Company) founded a private hospital at Kampong Minjak (Palembang, Sumatra) to take care of its European employees and contractcoolies. This hospital was under the management of a European physician.

b. The Royal Dutch Oil Company started two hospitals on South-East Borneo as well: one for European staff and one for the indigenous workers. Both stood under supervision of a European physician. At Tarakan, a smaller hospital had been established under the

68 Bijblad Staatsblad van Nederlandsch-Indië 4638, Gouvernementsbesluit van 21 September 1900 no.20 (Supplement NI Statutebook no. 4638, Government Decision no. 20 of 21 September 1900).

69 Regeeringsalmanak 1909, Kalender en Personalia, 481.

70 The hospitals of the so-called Pasemahlanden are mentioned in the Koloniaal Verslag 1907, 175.

71 Apart from the private company hospitals, a number of Government owned mines exploited hospitals, such as the ones at Bangka tin mines. 
supervision of a dokter djawa in 1906.

c. In 1906, another oil company, the Dordtsche Petroleum Maatschappij established a hospital near Rembang in Tjepoe (Java).

\section{Other company hospitals}

In 1906, the Nederlandsch Indische Industrie en Handel Maatschappij established a hospital at Balikpapan (Borneo) with one European doctor and in the same year another at Moearadjawa with a European doctor. A third hospital was founded in 1906 at Sanga Sanga Dalam under supervision of a dokter djawa.

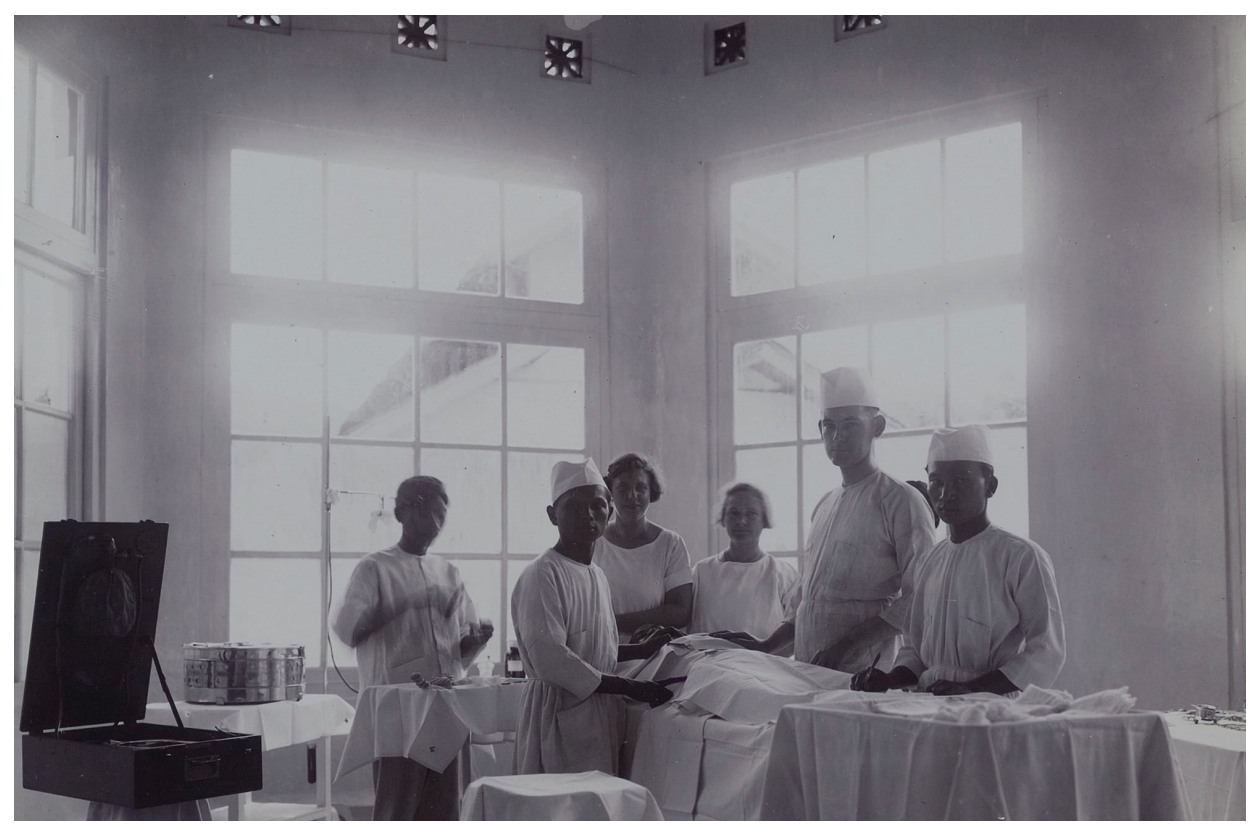

Figure 10 Operating theatre Ombilin Mine (Source: KITLV)

\section{SPECIALIZED HOSPITALS}

As mentioned previously, specialized hospitals existed since the $18^{\text {th }}$ century. They were founded to care for specific health problems, such as:

- Leprosy and cholera, because of fear of contamination;

- Syphilis, taking measures in the interest of morality and public order;

- Psychiatry, in the interest of safety and public order

A number of these facilities were extended or improved in the second half of the $19^{\text {th }}$ century. Prior to the 1890s, about 10 separate hospitals for sick prostitutes had been founded, mostly small facilities for 10 to 30 women, except for Batavia (80) and Soerabaja 
(300). New initiatives were taken, especially in the field of syphilis and in this category facilities were temporarily increased, but the policy of "averting the harmful consequences resulting of prostitution" met with increasing criticism concerning the usefulness of the involuntary hospitalization of prostitutes.

After 1890, a new category of facilities arose: hospitals and outpatient clinics for eye diseases. The facilities for beriberi patients appeared to be insufficient and took increasing numbers of patients. The other categories expanded after 1890, especially, the psychiatric and leprosy institutions. After 1900, the general hospitals ousted the specialized hospitals from the first place in civil hospital care.

\section{Hospitals for syphilitic patients}

The policy in preceding years to establish health facilities for prostitutes was continued between 1890 -1910, when 14 new hospitals were founded. ${ }^{72}$ After 1850, police regulations were issued and regular checks were organized in many places. For the women afflicted with venereal disease, a place was isolated in the sick-berth of prisons, or separate wards in indigenous hospitals. If the number of sick women became too large, separate sheds or barracks were placed with only elementary equipment. Sometimes, separate hospitals were brought into existence. The best known was the Pegirian Institute near Soerabaja. In August 1890, a renewal of the old policy was formulated. This occurred following advice from medical officials. ${ }^{73}$ Long years of experience with the existing regulations had taught that there was some positive effect according to the medical inspectors. They believed that repeal of the medical examinations would result in an increase in venereal diseases. Therefore, the government decided that the system should not be changed, though some of the police by-laws might require correction.

In the meantime, this problem had assumed new and larger proportions: in the city of Batavia, new facilities were requested for European and Indo-European women. Under the existing policy of segregation, a separation took place between visitation and treatment of indigenous prostitutes and visitation and treatment of European and Indo-European prostitutes. New police by-laws were announced that allowed for these new developments. In 1890, a regular inspection of prostitutes took place on Java at 394 locations, whereas in 70 places treatment and nursing was given. As mentioned before, these health facilities could be situated in a separate building or could be connected to an indigenous prison.

72 The Annex to the KV 1911 mentions a total of 60 hospitals for Java and 18 for the Outer Islands and this may explain the high theoretical number of syphilitic hospitals at the start of the period in 1890 (57). Just after the end of 1910 it was reported that on the 1st of March 1911 the Pegirian hospital would be closed.

73 The Dutch government had asked the NI government to reassess the policy on this issue. The recommendations of international conferences on syphilis incited this discussion. In the KV 1890 this advice was discussed. In the years 1890 until 1892, the chapter in the Koloniaal Verslag reporting about the Burgerlijke Geneeskundige Dienst (Civil Medical Service) was extended by a paragraph about prostitution. 
A few years before, 12,705 women received treatment, of whom 11,429 recovered and were dismissed. At the end of 1888, a total of 1,261 beds remained occupied at 70 locations. 15 women died in that year. In the same year, the report of the Outer Islands mentioned an obligation to visit 24 locations, mainly the capitals of the regions. In three capitals (Benkoelen, Telok Betung and Menado) the police reported that no prostitutes were known. At 18 places, information was available on the number of treated prostitutes: 653, of whom 615 recovered.

According to the Director of the department of Education, Worship and Industry, P.H. van der Kemp (1889-1894), about $f 1.4$ million was spent on inspection and treatment in a period of 10 years, from 1878 to $1887 .{ }^{74}$ Few funds were allocated to maintenance and renovation of buildings. The NI Government allowed the following numbers of personnel: for every 30 prostitutes, one female servant. In addition, one mandoer, when there were more than 10 prostitutes. $^{75}$

\section{Leprosy institutions}

Halfway during the $19^{\text {th }}$ century, about eight leprosy institutions existed in the Netherlands Indies, but the number of patients in these institutions decreased during the second half of the century. The 1891 Koloniaal Verslag starts its report on leprosy by stating that in the few leprosy institutions still left, mostly situated on Java, a certain number of patients had been treated.

Since the 1850s, three institutions were closed: in Gorontalo (North Celebes), in Benkoelen (Sumatra) and one on the Riouw archipelago. Only five institutions remained: one in Palembang (Sumatra), two in the so-called Vorstenlanden (Principalities) on Java, one military institution mainly for European lepers at Pelantoengan and a very small one on the island of Ternate. The two institutions in the Vorstenlanden (one in Djokjakarta and in Soerakarta) were mainly financed by the Javanese nobility and by the sultan. The government financed only the salaries of the leprosy institution on Riouw. The other income came from revenues of a Chinese capital reserved for this institution.

In view of the policy formulated by the government, there was no need to isolate the leprosy patients and this meant that they could be admitted into general hospitals. Closing the leprosy institutions did not mean that the prevalence of leprosy had diminished. It only indicated that there was no more need to separate these patients from other patients. It may not have been accidental that the leprosy-asylums that did not close their doors and kept a large number of patients were situated in the Vorstenlanden. Maybe in these regions

\footnotetext{
74 The distribution of these costs was remarkable: In the year 1887, the following amounts were spent: For food of the sick women an amount of $f 55,726$ (46\%); for travel expenses of the visiting physicians $f 37,972$ (32\%); for salaries only $f 18,743$ $(16 \%)$ and for medicines and other means $f 7,612(6 \%)$.

75 Staatsblad van Nederlandsch-Indië no. 127 van 6 Mei 1876 (NI Statutebook no. 127 of 6 May 1876).
} 
the attitude towards leprosy had not changed: people still felt uncomfortable and did not allow the leprosy victims to live together with the healthy population. The policy of the NI Government was that the continuing of separate institutions for leprosy patients was to be discouraged.

In the 1890s, after a period of doubting the contagiousness of leprosy, opinion changed again. It appears that the chief of the medical services had received the instruction to look into this question again. In August 1893, he reported that in his opinion leprosy was a contagious disease. However, only in a limited way and definitely less infectious than more common diseases such as syphilis, smallpox and tuberculosis. Therefore, there was no need to force leprosy patients to live isolated. ${ }^{76}$

New developments took place after 1890. An international congress in Berlin pronounced that leprosy was a contagious disease. Together with this view and the discovery of a leprosy bacil by Hansen, the degree of tolerance for keeping leprosy patients amid the healthy population, decreased noticeably. Consequently, new initiatives to establish leprosy institutions were put forth.

First, a new leprosy facility was founded at Medan (SOK) in $1894 .^{77}$ This hospital with 100 beds was integrated into the asylum for immigrants in the same city. Later it was reported to be fully occupied. In 1897, another leprosy institution is mentioned to be at Tandjong Poera (Lower Langkat). Both institutions were established on the East Coast of Sumatra and had been financed by wealthy Chinese. The Chinese population cared for this group, as many cases of leprosy had been observed among the Chinese. In the same year was founded, in the Western part of Borneo a leprosy hospital at Singkawang near the town of Pontianak. It was the explicit wish of the population to provide for the expenditure of this institution. In 1898, a new initiative was taken at Bindjei (Upper Langkat): this facility could accommodate 20 leprosy patients.

The number of leprosy hospitals had been reduced from eight (1868) to four (1893) and had increased to eight again in 1898. During the years 1900-1910, new developments were reported for Sumatra and Borneo, starting with two leprosy kampongs that had been established on the island Kota Pu Amal (Atjeh). At Koeala Boega Itam near Lengo Tjoet in the Landschap Peurenka about 9 leprosy patients were isolated and housed in a building of atap material. In 1905, the leprosy institution at Hoeta Salem, founded by the Rheinische Mission, was subsidized by the Dutch. A Dutch mission organization started an asylum for leprosy at Laoe Si Momo on the Karo Mountains (East Coast Sumatra) in 1908 (see Figure 11). In 1909, the Resident at Palembang was authorized to start a leprosy asylum on the land of a private citizen. He received the promise of subsidy for this initiative. On the island Temadjoe (Western Borneo) a facility had been founded for six patients and was

76 Already in 1865 (consulting the Annex to the NI Statutebook no. 1715) the NI Government held the same view.

77 SOK: Sumatra’s Oost Kust (East Coast Sumatra). 


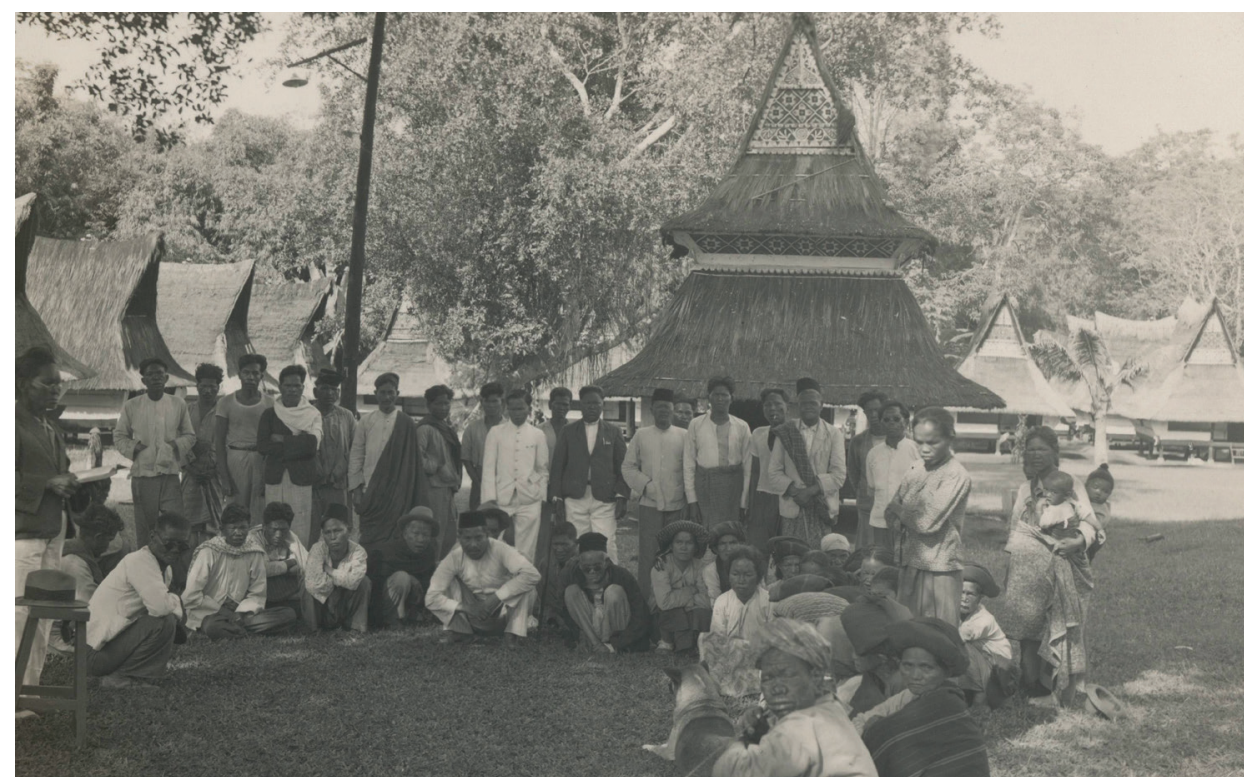

Figure 11 Leprosy village at Laoe Si Momo (Source: KITLV)

maintained by voluntary contributions of the population. In order to look into the prevalence of lepra and the huisverpleging (home-nursing) of leprosy patients at Soerabaja, a small subsidy of $f$ 2,250 was granted in 1909 to the shortly before established Vereeniging tot bestrijding van lepra (Association to fight Leprosy) at Batavia.

Suddenly a lot of activity occurred, resulting from initiatives of different groups. Apparently, the new activities arose from an attitude, which did not comply with the government view. Since scientific opinions remained divided, the government's view may have been prompted by economic considerations. Nevertheless, the government could not disregard the changing attitude of the population. Therefore, the governmental decision of 1865 was withdrawn in 1907 and leprosy was again considered an infectious disease. The school commissions were informed that children suffering from leprosy should be denied admission to school and still other measures were considered. ${ }^{78}$

In 1911, the Koloniaal Verslag reports a total of 20 leprosy institutions, of which four were accountable to the government and 16 were run privately. On Java there were six institutions and in the Outer Provinces $14 .^{79}$ (See also Appendix 2).

78 Gouvernements Besluit 23 October 1907 no. 11 (Supplement NI Statutebook no. 6768).

79 Koloniaal Verslag 1911, Annex S, IX, mentions that the military leprosy institution at Pelantoengan (Java) will be managed by the Salvation Army. The number of leprosy patients on Java were reported to total 1,617 patients and those for the Outer Islands: 5,404. 


\section{Eye Hospitals}

De Vereeniging tot verbetering van het lot der blinden in NI was founded in 1906 and had a broader scope than the name suggests: it actively pursued the aim to fight all kinds of eye diseases by encouraging preventive, especially hygienic measures. ${ }^{80}$ The ophthalmologist C.H.A. Westhoff acted as its first chairman. ${ }^{81}$

In 1890, almost 10,000 civilian eye patients had been treated, ranking the $5^{\text {th }}$ in frequency among ten categories of diseases. Because of the poor hygienic circumstances many inflammations of the conjunctiva were seen and needed surgical intervention. Many children were victims of trachoma, a chronic inflammation leading to blindness, if untreated. ${ }^{82}$ In some parts of the archipelago, trachoma was found in more than $20 \%$ of the population. The northern part of Java, the Moluccas and Atjeh were the regions that were most strongly affected. Besides trachoma, cataract, avitaminose and venereal diseases caused a lot of blindness. The most severe cases of trachoma were reported in the coastal areas of West and Central Java. The 1902 Civil Medical Service annual report mentioned a variety of eye problems that required medical assistance. Since many children suffered from eye diseases, specialized outpatient clinics were established in some towns. In Central Java, these diseases received considerable attention, ultimately leading to the foundation of an Eye Hospital. In 1901, the opening of an outpatient clinic for eye diseases was subsidized on request of the ophthalmologist Westhoff. This ophthalmologist was given the assignment to train indigenous eye doctors (called doekoens mata) on an experimental base. Westhoff gave considerable attention and energy to this training and achieved some success. There was published a list of 18 doekoens mata for Java in the 1909 Annual Report of the Civil Medical Service.

However, since there was a lot of criticism from the medical profession, this experiment was soon stopped. In 1909, the official opening of the Koningin Wilhelmina Gasthuis voor ooglijders at Bandoeng took place by the Governor-General J.B. van Heutsz. Westhoff was appointed as its first director.

One of the health officers in the Semarang region, P. Wijn, was an ardent champion of eye clinics. In 1904, he started an eye clinic at Ngawi (Central Java) and advocated establishment of more facilities for eye diseases. He reported some successes in treating eye patients with the following comment: "The fact that in a short time about 1,000 eye patients apply for

80 The bylaws of the Vereeniging tot verbetering van het lot der blinden in Nederlandsch Oost-Indie (Association to improve life conditions of blind people) were approved by Government Decision of 6 August 1901.

81 The ophthalmologist Christiann Hermann August Westhoff (1848-1913) took his PhD under supervision of Donders at Utrecht and started his medical career as health officer in 1871. In 1909, Westhoff was appointed director of the Koningin Wilhelmina Gasthuis voor Ooglijders at Bandoeng.

82 Trachoma is caused by Chlamydia trachomatis - a microorganism which spreads through contact with eye discharge from the infected person (on towels, handkerchiefs, fingers, etc.) and through transmission by eye-seeking flies. After years of repeated infection, the inside of the eyelid may be scarred so severely that the eyelid turns inward and the lashes rub on the eyeball, scarring the cornea (the front of the eye). If untreated, this condition leads to the formation of irreversible corneal opacities and blindness (WHO definition, 29-3-2014). 
help proves the great need for large parts of the population to get eye treatment. Occasionally, there will be about 100 patients at the same time on one day. Many of them come from far away and to my astonishment they sometimes stay in the neighbourhood for two or three months to be treated daily for a short while." ${ }^{83}$

In 1908, the Salvation Army started an Eye hospital at Semarang with on average 80 inpatients. ${ }^{84}$ The number of outpatient consults was 31,217 in 1910 with 900 new patients. In 1909, Liem Tik Koey, a former Chinese sugar mill owner, founded an association to care for wounded and sick people, at Kertosono (Residency Kediri, Central Java). The hospital was primarily intended for patients suffering from eye diseases. ${ }^{85}$ After 1913 , this eye clinic regularly received subsidy from the NI government. Eventually, similar initiatives would follow after 1910 .

\section{Convalescent clinics}

Some of these clinics were founded by European doctors who earned a nice income by running these places. Some were started by hotel owners who contracted nearby doctors to look after the patients on a more or less regular base. Nearly all the health resorts were situated on Java, only one was opened on Sumatra, in the Deli country, the clinic at Bandar Bahroe.

In 1890, a number of three convalescent centres existed: at Soekaboemi the health resort Selabatoe, founded in 1884 (see Figure 12), at Buitenzorg the resort Gadok (1853) and one at Sindanglaija (1877). After 1890, some new resorts were founded: one at Pasoeroean (1893), one at Tosari (1893) and a third one at Kedoe (1900). In official publications, attention was paid to this kind of institutions. They appear under various names in the reports of the civil administration: Gezondheidsetablissement, Sanatorium, Herstellingsoord, Reconvalescentiegesticht and Badetablissement. The public interest was the result of the fact that almost only European patients were admitted.

A number of initiatives were put forth, either by medical doctors or by high placed civil servants to explore several mountainous areas to assess whether they were suitable as a location for convalescence. The army rewarded some of their officers, who had led severe expeditions and had fallen ill, with a stay in a gezondheidsetablissement. As many people were eager to pass some time in a similar institution, complicated arrangements and regulations were issued to sort out who was allowed to stay in which establishment and in which class. The regulations stipulated who were to be charged and who were admitted free of charge and the payment of the owner. In the last years of the 1890s, when a number of people were fighting in Atjeh or had been placed there for forced labour, many of them

83 P. Wijn, "Verslag der Ophtalmologische kliniek en polikliniek te Ngawi over 1904" (Annual report on the Ophthalmological clinic and polyclinic) GTNI 45 (1905) 723-728.

84 W.A. Wille, "Eerste jaarverslag van de Oogkliniek van het Leger des Heils te Semarang over de Jaren 1908/1912" (First annual report of the Salvation Army Eye clinic at Semarang) GTNI 54 (1914) 8-30.

85 Koloniaal Verslag 1910, 161-162. 
contracted beriberi. While most of the patients went to separate Beriberi hospitals some were sent to health facilities such as Kampong Makassar near Batavia. The official count of the $K V$ in 1911 recorded three institutions on Java and one on Sumatra, but a close study of the successive reports tells that at least about ten convalescence clinics were established.

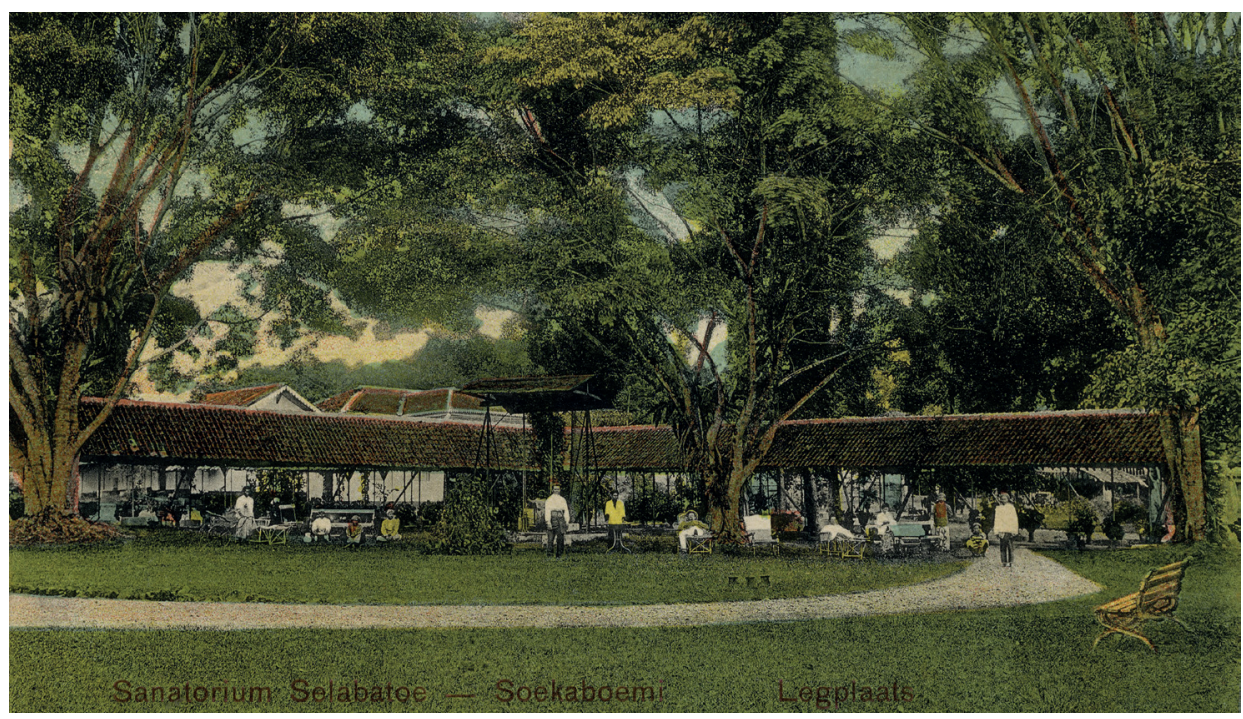

Figure 12 Sanatorium Soekaboemi (West Java) (Source: KITLV)

The photo shows the health resort at Soekaboemi that had been opened in 1884 and that was used for sick military personnel too. When the hospitals of Batavia and Buitenzorg were overcrowded in April 1885 it was also used for sick convicts, mainly suffering from beriberi.

\section{Hospitals for beriberi patients}

In the 1890s many people who had worked or fought in the Atjeh region were affected by beriberi. The coolies on the plantations of the East Coast of Sumatra also suffered from this disease for which there seemed to be no cure.

Yet, astonishing effects were observed when the afflicted people were evacuated to other places, sometimes on the same island, sometimes elsewhere. The hospitals at Buitenzorg on Java and at Oeloe Limau Manis near Padang (West Coast of Sumatra) reported satisfying results due to the change of air and surroundings.

After 1889, a large expansion took place, especially at the hospital in Buitenzorg. Next to the existing 1,100 beds an extension was built for five wards, each for 70 patients with connecting covered passageways. The hospital was exclusively assigned to convicts, affected by beriberi. In 1889, it admitted 1,009 convicts of whom 600 left the hospital (389 because of the end of their sentence, 58 died, and 149 recovered, while 7 escaped). At the end of the 
year, the number of occupied beds had increased to 1560. Although the number of recovered patients was rather small compared to the total number of admissions, the staff of the hospital considered the outcome satisfactory. Soon after arrival the general health condition improved and the most serious symptoms disappeared. To achieve complete recovery only required time. Sick patients were given as much air and free movement as possible and some even took on light work. The planned extension had been completed by the end of 1889 and the hospital had a capacity of 1,650 patients. The beriberi patients who had been evacuated to the Batavia City Dressing Station could now be nursed in a much healthier environment. In 1891, another extension of two semi-permanent wards was completed. In 1893, five new loodsen (sheds) were built, each for 100 patients. The complete building now contained nine semi-permanent and seven bamboo sheds. In 1895/1896, three new sheds were added for each 100 beds. In order to treat and nurse Chinese miners from the island of Bangka who had been evacuated because of beriberi, three additional and separate wards for each 75 patients were built in April 1895.

The beriberi hospital that had been founded at Oeloe Limau Manis near Padang was designated to take care of the sick convicts from Atjeh.

At Loeboe Pakam (East Coast of Sumatra) a temporary provision was made for the treatment of prisoners, suffering from beriberi. A small beriberi institution was built in Wangkal on Java. It was closed two years later because of a lack of patients. Apparently, the Buitenzorg hospital attracted all the beriberi patients. But the future of the Buitenzorg hospital too became uncertain as the number of patients gradually diminished. With the Government Decision of 17 July 1905 (no. 104) the beriberi hospital at Buitenzorg became available as an indigenous hospital, awaiting further decisions about its future.

\section{Psychiatric hospitals}

As described in Chapter 3, Psychiatry was the only health sector in the Netherlands Indies with an advanced hospital capacity planning, early in the second half of the $19^{\text {th }}$ century. To support this planning, research was accomplished by two experts appointed by the Dutch government. Based on their findings, there took place the establishment of a new modern psychiatric hospital.

The Krankzinnigengesticht at Buitenzorg was inaugurated in $1882 .{ }^{86}$ The Buitenzorg hospital gradually acquired extensions and the initially planned capacity of 500 beds, was finally completed by its director L.B.E. Ledeboer in 1897. From this year, a continuing range of expansions took place, not only at the Buitenzorg hospital, but of many other psychiatric

86 J.H. Bauer and W.M. Smit, Verslag van het onderzoek naar den tegenwoordigen toestant van het krankzinnigenwezen in het algemeen en van de gestichten en verblijven der krankzinnigen in Nederlandsch-Indië in het bijzonder, met aanwijzing der middelen welke tot verbetering kunnen worden aangewend (Landsdrukkerij Batavia, 1868). Research-report on the situation of psychiatry in the NI with recommendations. 
hospitals as well. Together with the Buitenzorg hospital, two auxiliary hospitals at Semarang (Mid-Java) and Soerabaja (East Java) were maintained for some time with a capacity of about 100 patients each. In 1901, the Semarang asylum was closed and in 1905 the Soerabaja asylum. A new large hospital at Lawang (East Java) replaced these facilities. The Lawang hospital was designed by S. Lykles and opened in $1902 .{ }^{87}$ Both hospitals expanded to a capacity of 750 beds (Buitenzorg) and 900 beds (Lawang) by 1907. Like most planning activities in the health sector, the initial planned capacity of 500 beds was tripled and even this appeared to be inadequate. By the end of 1910, provisions were made for two or three additional hospitals.

\section{Hospitals for infectious diseases (dysentery, cholera, smallpox)}

Dutch legislation concerning infectious diseases dated from 1872 and 1884, when was issued the Wet op de besmettelijke ziekten (Law on contagious diseases). This law distinguished seven types of contagious diseases. In the Netherlands Indies, the NI Ordinance of February 1892 summed up a limited number of contagious diseases and emphasized the dangers of importing these diseases from overseas. Both these legal statutes regulated the medical supervision, publication, isolation, nursing and transport of patients. These regulations also stipulated the way deceased persons should be buried and how to dispose of contaminated objects. The care for disinfection included expropriation, destruction and compensation. Before 1890, a few hospitals, sometimes temporary facilities, were built near large harbours to cope with sudden epidemics, imported from abroad. Often they were extensions or annexes to existing general hospitals, but in some cases there was created a separate hospital.

After 1890, hospitals for infectious diseases were established in three harbour cities. One was at Soerabaja. In 1894, a cholera hospital was built on the river Oedjoeng. Another was built near Batavia at Tandjong Priok and a further one at Padang (West Coast Sumatra), where in 1893 near the Emma-harbour a small simple building arose to care for 6 patients. In that same year, the government supplied an amount of $f 8,710$ to build a cholera-hospital at Olehleh (Atjeh).

As dysentery claimed a lot of victims on Nias, in Natal and Batang Natal in the Residency Tapanoeli (Sumatra), $f 2000$ was supplied to build barracks for dysentery-patients. ${ }^{88}$ No mention was made of typhoid fever or hospitals for that disease. The Koloniaal Verslag 1911 remarks that the incidence of typhoid fever was probably larger than the reported number, while most cases were counted in the undifferentiated group of fevers.

87 D.J. Hulshoff Poll, Verslag omtrent het Gouvernements Krankzinnigengesticht te Lawang (Residentie Pasoeroean) vanaf de opening op 23 juni 1902 tot ultimo 1905, benevens een overzicht van de wordingsgeschiedenis daarvan (Batavia 1906). Report on the Psychiatric hospital at Lawang from its opening and a survey of its recent history. 


\section{SOME HOSPITAL FIGURES}

Between 1890-1910 many new hospitals were founded and others were closed. The CMS budget increased by about $75 \%$. In addition to the establishment of hospitals by this public service, more new hospitals were started through private initiatives. The category general charity hospitals grew from 0 to 26. The number of company hospitals from 6 to 45 . The other general hospitals from 32 to 81 . Taken together, in merely 20 years, 114 new general hospitals had been established, Thanks to the initiatives of private parties: 65 , by the government: 49 . In contrast to this increase in civil general hospitals, the number of military hospitals decreased. Specialized hospitals increased from 41 to 102, which was mostly due to the intensified fight against prostitution. With 78 facilities, the number of syphilis hospitals amounted to $76 \%$ of the total (102)

Table 6 Number of Hospitals 1890 and 1910

\begin{tabular}{|c|c|c|c|c|c|c|}
\hline \multirow[t]{2}{*}{ Description } & \multicolumn{2}{|c|}{ Java \& Madoera } & \multicolumn{2}{|c|}{ Outer Provinces } & \multicolumn{2}{|c|}{ Total } \\
\hline & 1890 & 1910 & 1890 & 1910 & 1890 & 1910 \\
\hline Military hospitals & 17 & 8 & 15 & 14 & 32 & 22 \\
\hline Public general hospitals & 5 & 10 & 0 & 0 & 5 & 10 \\
\hline Indigenous general hospitals & 13 & 29 & 14 & 42 & 27 & 71 \\
\hline Charity general hospitals & 0 & 21 & 0 & 5 & 0 & 26 \\
\hline Company general hospitals & 1 & 10 & 5 & 35 & 6 & 45 \\
\hline Specialized hospitals & 32 & 69 & 9 & 33 & 41 & 102 \\
\hline Total hospitals & 68 & 147 & 43 & 129 & 111 & 276 \\
\hline
\end{tabular}

Source: For 1890, Table 4, chapter 2 and for 1910, KV 1911, Appendix S, Table I

\section{A few additional comments}

- The numbers of the military hospitals did not include the so-called ziekenzalen (Infirmaries);

- The ten public general hospitals included two psychiatric asylums (Buitenzorg and Lawang), the beriberi institution at Buitenzorg, three City Dressing Stations, one auxiliary City Dressing Station, two Chinese hospitals and one almshouse. All ten together were arranged within the category Centrale Burgerlijke Ziekengestichten (Central Civil Hospitals). Three of them should be grouped under the specialized hospitals.

\section{A NEW FUTURE FOR THE CIVIL MEDICAL SERVICE}

The last decades of the $19^{\text {th }}$ century brought with them new challenges and impulses. The rising private medical care and the diminishing influence of the military precipitated developments towards an independent sector of civil medical care. The old structures of restricted and mostly involuntary care for civil had become obsolete. Makeshift solutions 
had been tried to create room for civil health care. However, the real issue was that military health care and civil health care should become separated.

A commission was nominated by Governor-General J.B. van Heutsz at the end of $1906 .{ }^{89}$ This commission was assigned the task to prepare a reorganization of the Civil Medical Service. For almost 90 years the Civil Medical Service had been under the supervision of the Chief of the Military Medical Service and a separation of both services was judged necessary to achieve improvements in both services. The commission was asked to report on all aspects concerning this separation. The chairman of the Reorganization Commission was lieutenant-colonel J. Bijker, directing health officer $11^{\text {st }}$ class.$^{90}$ Five members and a secretary were appointed. The members were: G. Winkler, inspector of the CMS for Java; L.J. Eilerts de Haan, senior city doctor of Batavia; A.A. Nijland, director Institute Pasteur and Landskoepokinrichting; D.L. Stibbe, health officer $1^{\text {st }}$ class and J. Schülein, private doctor at Soekaboemi. The secretary was a public servant of the Department of Education, Worship and Industry, H.G.C. Degent.

The Reorganization Commission worked thoroughly and managed to deliver her final conclusions to the Governor-General within 3 years. The conclusions were far-reaching and regarded the internal organization of the head office and its manpower, hospitals, inspection, finances, functional issues and structural measures. To achieve all of these issues, a budget increase was required, which was discussed in the Dutch parliament in October 1909, together with the essential conclusions laid down in the Memorie van Toelichting (explanatory memorandum) of the Minister of Colonies, J.H. De Waal Malefijt. An additional budget was voted of $f 369,860$ for the year 1910 .

Politically the report was well received, both by the authorities in the NI and the Dutch parliament. There were critical notes though: from individual members of parliament and members of the medical profession. These critical notes were published in issues of medical reviews, such as the Geneeskundig Tijdschrift voor Nederlandsch Indië and the Nederlands Tijdschrift voor Geneeskunde. These articles sometimes led to prolonged discussions.

One important issue, as voiced by the parliamentary member W.H. Boogaardt, were the shortcomings of the Civil Medical Service in the field of prevention, leprosy and quality of civil hospitals. ${ }^{91}$ The former Chief of the Medical Service, J. Haga, responded to these criticisms in an article in the Nederlands Tijdschrift voor Geneeskunde. ${ }^{92}$ Some conclusions of the Reorganisation Commission were contradicted by professional experts. Critical was the response concerning allegations against certified indigenous midwives. They were,

89 Gouvernements Besluit no. 15 van 3 December 1906 (Government Decision no. 15 of 3 December 1906).

90 In the following pages the commission will be mentioned frequently. I will refer to the Reorganization Commission, meaning this commission of 3 December 1906.

91 The member of parliament W.H. Bogaardt, member of the Rooms-Katholieke Staats Partij, submitted a critical Memorandum, called "Civiel Geneeskundige Dienst in Nederlandsch Indië”.

92 J. Haga, “Civiel Geneeskundige Dienst in Nederlandsch Indië”, Ned Tijdschr Geneeskd (1910) 1323 - 1327. 
according to some members of the Reorganization Commission, judged less effective than doekoens and could give rise to a number of concerns during childbirth, such as puerperal fever due to unhygienic behaviour of the midwife. ${ }^{93}$ F.S. Stibbe ranted against this opinion in an article in the GTNI.

The report encompassed 7 chapters and a number of appendices. A far reaching recommendation in chapter 4 of the report was, to terminate the surveillance and hospitalization of prostitutes. By 1911, this meant the closure of all the specialized hospitals for syphilis. Chapter 2 of the Reorganization Report described the different functional elements of the new Civil Medical Service. These included the medical inspection (Staatstoezicht), health research, study of diseases and therapies, means to improve public health, medical legislation and implementation of regulations. As for direct care: The Civil Medical Service should organize medical treatment and care of patients and look after distribution of medicines. The Civil Medical Service should establish free polyclinics and public hospitals and subsidize private hospitals. Additional tasks that had to be performed: the training of health care professionals and examination of applicants for licenses of medicine, pharmacy, midwifery and dentistry.

Chapter 6 regulated public hospitals. They were summed up as follows:

- Three City Dressing Stations at Batavia, Semarang and Soerabaja;

- The inlandsche burgerlijke ziekeninrichtingen. No numbers were mentioned, later on they would be called GBZs (Gouvernements burgerlijke ziekeninrichtingen);

- The Gestichten voor zieke prostituees (hospitals for sick prostitutes);

- Two krankzinnigengestichten (mental hospitals) at Lawang and Buitenzorg

- The Quarantaine-inrichtingen (quarantine institutions);

- Two Chinese hospitals at Batavia and Semarang;

- The beriberi gesticht at Buitenzorg;

- The Armenverzorgingsgesticht at Semaroong (Soerabaja).

The Reorganization Commission advised to collapse the second and third category of this list together and to call them henceforth "s' Lands burgerlijke ziekeninrichtingen."

Appendix III of the Report counted 92 hospitals for these two categories. Eventually, all of the first three categories were placed together and referred to as Gouvernements Burgerlijke Ziekeninrichting (GBZ, Government Civil Hospital). The three City Dressing Stations were called Centrale Burgerlijke Ziekeninrichting (CBZ). Interestingly, there was a recommendation to establish hospitals in any place where was stationed a medical doctor or a dokter djawa employed by the government. It underlined the idea that inlandsche hospitals were simple

93 F.S. Stibbe, "Kritiek op het Rapport der Commissie tot Voorbereiding eener Reorganisatie van den Burgerlijken Geneeskundigen Dienst, Verloskundige praktijk in de dessa" (Criticism of the Report of the Reorganization Commission, Midwifery in the desa) GTNI 49 (1909) 385-415. 
and basic institutions. The practice to make outpatient visits without having some hospital provision at hand would be replaced by outpatient facilities adjacent to hospitals. The Law of 26 September 1910 made funds available to finance the various provisions recommended by the Reorganization Commission.

From 16 January 1911 the Burgerlijke Geneeskundige Dienst (Civil Medical Service) was directed by the Chief Inspector of the CMS, J. Schülein, and henceforth the combined function of the former military chief (as head of CMS and MMS) belonged to the past. ${ }^{94}$ It was evident to anyone involved in civil health care that drastic reforms were unavoidable in view of the challenges of the new age.

\section{SUMMARY}

In the previous pages there has been presented a palette of various hospitals. These hospitals started before 1890 or after that year and the activities of these institutions were followed up to the period 1890-1910.These two decades are grouped around the turn of the century and may be characterized by revolutionary changes. The way in which changes took place was laid out in the first few paragraphs. They formed the introduction to the real issue: what happened in the field of health care and more specifically in the field of hospital care?

The preceding paragraphs demonstrated a few significant developments. The most important was the change in relations and power between the two big players in the field of health care, the CMS (Civil Medical Service) and the MMS (Military Medical Service). The achievements and developments of both organizations were described. Besides the two public health services, two new significant players presented themselves in the field of hospital care: companies and charity organizations.

I tried to answer some essential questions in this period of transition: why did new actors appear on the stage of hospital care? What caused their drive to surmount the problems of starting new hospitals? A variety of motives were discussed, mostly depending on the kind of initiating organization. The motive could be charity, self-interest or a mixture of both. Use of the hospitals during this period can best be described as follows: after a hesitant start, indigenous patients began to consult the new facilities. At first, to obtain medication, treatment for minor health problems or looking for help as a last resort. Later, use included being hospitalized, although at first hospital admissions were persistently avoided or refused. The success of hospital services with the population depended upon the attitude of the doctors, the reputation of the hospital and the tariffs charged. As patients generally were poor and had no means to pay health visits, the hospital bill became an important issue. However, for quite a number of the new hospitals the treatment and nursing was for

94 Staatsblad van Nederlandsch-Indië no. 650 van 24 December 1910 (NI Statutebook no.650). 
free. This was the case for employees who visited their company hospital and for civil servants below a certain income. Patients who could prove that they were poor and had no means to pay were treated with no costs.

As far as the type of hospitals is concerned: a division was made between general hospitals and specialized hospitals. Within the first group, the developments of government hospitals were examined. They benefited from the newly announced ethical politics and grew in number and quality. However, the two new groups of general hospitals (company and charity) showed more innovations than the government hospitals. The Djokja system was described, a network system of hospitals, auxiliary hospitals and outpatient clinics. This system became a model that attracted many adherents. The other major innovation came from the Deaconess hospitals, which put considerable effort into the training of a professional nursing staff. The third group of general hospitals that was described was the group that started company hospitals. Apart from a lot of criticism that this group met because of their dependence on the detested Coolie Ordinance, they earned credits for their role in the improvement of hospital care by organizing patient files and statistics and by making use of analytical and research laboratories.

Then there was discussed a number of specialized hospitals for leprosy, venereal diseases, convalescence, infectious diseases, beriberi and psychiatry. The future of this type of hospitals partly depended on the health policy that the authorities pursued (leprosy, syphilis) and partly on the outcome and application of scientific research (beriberi and infectious disease).

\section{What may be learnt from these experiences?}

First of all, the focus of colonial health care had been on European VOC servants or European military with some exceptions, mostly due to preventive care which was in the interest of the Europeans. From the end of the $19^{\text {th }}$ century, this focus shifted to the indigenous people of the Netherlands Indies.

Secondly, private initiatives in the field of hospital establishments gradually gained the upper hand compared to the initiatives of the military and of the government. Together with this development the monopoly situation of Java changed: by 1910 the number of general hospitals in the Outer Provinces surpassed that of Java (See Table 6: Counting the lines Public general + Indigenous general + Charity general + company general , the result becomes: 82 hospitals for the Outer Provinces and 70 for Java).

Thirdly, the ethical movement had a significant influence on developments in hospital care. More funds became available for government and charity hospitals. In the case of the latter, this occurred by way of financing lands and buildings and subsidies for running costs.

Finally, that training facilities showed results: the number of trained indigenous doctors reached almost the same level as the number of European doctors, at least when counting exclusively the civilian doctors (See Table 2, 164 civil physicians and 148 dokters-djawa). 
Additionally, there were preliminary start-ups for training facilities for indigenous nurses and midwives. Nevertheless, the situation in the field of professional nursing remained a concern.

No decisive statements can be made about the influence of Western hospitals and doctors on the health situation of the population. During the period discussed, the health situation remained unstable and varied by region and year. Health problems were often caused by incidental local or regional epidemics, or resulted from the food conditions and, in general, from hygienic circumstances and practices. 



\section{CHAPTER 5}

TIMES OF EXPANSION, TIMES OF AWAKENING

(1910-1930) 


\section{INTRODUCTION}

Circumstances and events in the Western world usually had also consequences for the colonies. This was certainly the case during the period 1910-1930. On the international scene, communism and socialism received popular support during the first part of this period and they had some influence in the colonies. In the Netherlands Indies, a call for more political influence of the autochthonous population arose, ranging from the desire to participate in political decision making to the urge to strive for independence. The most important event in these years was the First World War, which greatly influenced the political climate and the economic and financial affairs of the colonies. At the end of the war the whole world was affected by the influenza pandemic of 1918, which took millions of lives. In the Netherlands Indies too, hundreds of thousands of people died due to this so-called Spanish Flu.

For the greater part of the period 1910-1930, more money was available and this facilitated the expansion of education, health care and infrastructure. In keeping with the ethical politics, the NI government took the initiative to expand the number of schools and health facilities. New health facilities and preventive measures became necessary, when suddenly bubonic plague appeared in many homes, while the incidence of other diseases diminished, such as cholera, beriberi and yaws. Some diseases were combated by effective medicine and even seemed to vanish. The government encouraged local authorities and private foundations to join the health care ranks by creating and managing more facilities such as outpatient clinics and hospitals.

Infrastructure was improved, large investments went into housing, agricultural and transport sectors. More roads were built. Water supply and irrigation was improved, more railroads were constructed and houses rebuilt. Mining companies as well as public and private plantation estates flourished and earned a lot of money. The indigenous people profited from increasing exports of local products. A new middle-class of private and public functionaries (schoolmasters, technicians, civil servants) developed and the prosperity of the population, which had been at a very low level in the beginning of the century, gradually increased.

\section{POLITICS, ECONOMICS AND SOCIETY}

The ethical objectives, described in Chapter four, would eventually lead to legislation in the fields of emancipation, education and decentralization. Ultimately, decentralization would affect developments in health care most, but not until the second part of the 1920s. Colenbrander comments on decentralization in the NI in the first decades of the $20^{\text {th }}$ century. He describes how many attempts to realize this objective failed in the first two decades. This occurred mostly because of Dutch parliamentary developments or political events in the Netherlands. The Decentralization Act became operational in the Decentralization Decree of 1904 and by the Local Boards Ordinance of 1905, but apart from some precocious regions, 
the implementation took quite some time. ${ }^{1}$ This retardation affected developments in the field of health care. Most of the public hospitals remained government hospitals and there were only a few initiatives by local and regional boards to accept responsibility and establish new hospitals or take over the management of existing ones.

Furnivall too describes the administrative and political reforms that took place during this period. At the political level these reforms culminated in a new Constitution that was issued in 1922. This Grondwet recognized the Netherlands Indies as an integral part of the Kingdom. The Opperbestuur (Supreme Government) was vested in the Crown, but the general government was to be exercised by the Governor-General. Dutch national laws regulated which powers remained reserved for the Crown. The Staatsinrichting of 1925 placed limitations on the power of the Crown. ${ }^{2}$ It recognized the Volksraad (People's Council) as a legislative organ, albeit with limited jurisdiction and reduced the Raad van Indie (Council of NI) to an advisory body.

Prior to these reforms, between 1910 to 1922, the administrative system consisted of seven Departments, among which were Education, Worship and Industry. In 1911, this department lost the third element of its name: Industry. The Civil Medical Service remained part of the Department of Education and Worship, as established in 1882.

As for the territorial status and the managerial levels of the Netherlands Indies, there was a distinction between two different systems. Politically, there were Government Lands under direct rule and Native States under indirect rule of the NI Government. ${ }^{3}$ Administratively, the territories were divided into Gewesten. ${ }^{4}$ In Java the Gewesten were all termed Residencies. In the Outer provinces too, but areas of greater importance could be termed a Government. ${ }^{5}$

Van den Doel states that, in spite of the decentralization measures of 1904, the Netherlands Indies remained largely an apolitical state of civil servants. ${ }^{6}$ Nevertheless, there was a big difference between Java and the Outer Provinces. Java was administrated directly and intensively by the colonial administration, while in many of the Outer Provinces local rajas or sultans continued to rule their minor or major princedoms. This meant that in these regions, initiatives in the field of health care often had to await the approval of these rulers. Sometimes, new hospital establishments were initiated by them. For example, in the Outer Provinces some leprosy facilities were founded by the ruling sultan.

\footnotetext{
H.T. Colenbrander, Koloniale Geschiedenis, derde deel ('s Gravenhage 1926) 94-101.

Staatsinrichting: The way the state is administrated, organized and controlled.

Direct rule: the NI Government was in charge of all levels of command and the indigenous rulers had to obey the directions that came from the Dutch. Indirect rule: the native states had their own levels of command.

4 The situation concerning the administrative division of Java and Madoera in 1910 may be consulted in Appendix 3 and the situation for the Outer Provinces in that same year in Appendix 4.

5 Furnivall, Netherlands Indies, 257-301.

6 W. van den Doel, Zo ver de wereld strekt, de geschiedenis van Nederland overzee vanaf 1800 Transl.: As far as the world extends, the history of the Netherlands abroad from 1800 (Amsterdam 2011) 171.
} 
Apart from the political and administrative divisions, a third division needs to be distinguished, which is relevant here: The Burgerlijke Geneeskundige Indeling (Civil Medical Division). This Indeling divided Java and Madoera into medical districts and sub-districts, mainly corresponding with the administrative division. On Java, the medical doctors, dokters-djawa and inlandse artsen had 82 main posts and 46 secondary posts. ${ }^{7}$ Two Residencies in the Outer Provinces (Menado and Bangka) had likewise medical districts (called ressorten) and sub-districts, but in 1910 this was not the case for the majority of Residencies in the Outer Provinces. Finally, a network of vaccination districts was established both on Java and the Outer Provinces. In Java and Madoera 161 vaccination districts were created and in the Outer Provinces $280 .^{8}$

\section{Economics of the period}

De Jong calls the economic expansion, that the Netherlands Indies experienced after 1908, 'tempestuous'. 1908 was the year in which Governor-General A.F.W. Idenburg (1908-1916) succeeded van Heutsz. The economic expansion went on during the next twenty years and took place not only on Java, but more strongly in the Outer Provinces. Economic progress was stimulated by government measures, aiming at strengthening industrial and agricultural performance. The improvement in indigenous agriculture especially received considerable attention. This resulted in completing irrigation projects and introducing crop improvement schemes. This led to a better quality and higher quantity of production, both of which stimulated the export.

On Java, the production and trade of sugar and tea increased in these years. Not only the Western companies made large profits, but indigenous cultivation of coffee, tea, rubber and tobacco too proved to be successful. In 1929, $73 \%$ of the production of coffee, $45 \%$ of tobacco, $41 \%$ of all NI rubber and $22 \%$ of tea were produced by indigenous farmers. ${ }^{9}$ In that same year, $36 \%$ of all agricultural export value came from indigenous farmers. ${ }^{10}$

The increase in export figures in the Outer Provinces was even more astonishing. In the year 1905, only $29 \%$ of all export originated from these regions. During the four World War I years, this percentage rose to $43 \%$. In 1922 it went up to $54 \%$ and during the following years the percentage continued to rise, thus causing a real shift in the economic balance between Java and the Outer Provinces. ${ }^{11}$

The NI Government owned many public companies, hence, public finances prospered too and the budget for most departments increased annually. The expenditure of Public Finance grew from $f 205.1$ million in 1910 to $f 727.8$ million in 1929. It more than tripled in 20

\footnotetext{
7 Regeeringsalmanak 1910, Grondgebied en Bevolking, Annex EE, 364-391.

8 Regeeringsalmanak 1910, Grondgebied en Bevolking, Annex CC, 347-349 and Annex DD, 350-363.

9 De Jong, De waaier van fortuin, 404.

10 Furnivall, Netherlands India, 320.

11 De Jong, De waaier van fortuin, 402.
} 
years' time, although part of this increase was due to inflation. The total expenditure during this period was estimated at about $f 10$ billion, on average, about $f 500$ million a year. The tax revenue was estimated at $f 4.4$ billion and the revenue from public utilities at $f 4.7$ billion. ${ }^{12}$ The part of government expenditure allotted to the health care sector, is given in Table $7 .^{13}$

Table 7 Public Expenditure 1910 to 1930 (in million $f)^{14}$

\begin{tabular}{llll}
\hline Year & $\begin{array}{l}\text { Total Government } \\
\text { Expenditure }\end{array}$ & $\begin{array}{l}\text { Public Health } \\
\text { Expenditure }\end{array}$ & $\begin{array}{l}\text { Public Health as } \\
\text { \% of Total Expenditure }\end{array}$ \\
\hline 1910 & 205.1 & 3.4 & 1.7 \\
1915 & 286.6 & 11.1 & 3.9 \\
1920 & 890.7 & 15.3 & 1.7 \\
1930 & 825.4 & 20.7 & 2.5 \\
\hline
\end{tabular}

While the total government expenditure over 20 years more or less quadrupled, the nominal growth of health expenditure was six fold. The economies that had to be made to solve the NI budgetary deficits were only passed on to the health care sector in a mitigated way and this may explain the increase, compared to total expenditure from $1.7 \%$ to $2.5 \%{ }^{15}$

\section{The war and its aftermath}

It is interesting to consider the economic development during the World War I years. It appears that the trade figures in the period 1910-1919 showed a rate of expansion that exceeded previous years. This trend needs to be corrected for the increase in prices that resulted from the war. The exceptional performance in 1919 had to do with both circumstances, price inflation and an increase in demand that caught up on decreasing demand during war years. The sources of import and the destinations of export were subject to considerable shifts, partly due to problems of international shipping during this war. The Netherlands as the primary country of destination changed to the United States and many Asian countries.

12 P. Creutzberg, Changing Economy in Indonesia, Volume 2, Public Finance 1816-1939, table 4.

13 Furnivall, Netherlands Indies, 363.

14 These figures were not corrected for inflation.

15 According to Creutzberg, Changing Economy, Volume 2, table 4, the total expenditure decreased from an all-time high of $f 890.7$ million in 1920 to $f 459.5$ in 1934 . 
The course of total export value during the war years is illustrated in Figure $13 .{ }^{16}$ In 1919 , figures mirrored also a large rise of prices resulting from the war. ${ }^{17}$ Examination of the volumes of export commodities shows that the volumes of rubber products (> $300 \%$ ) and coffee (about $70 \%$ ) increased most (comparing 1919 with 1914).

Value of export

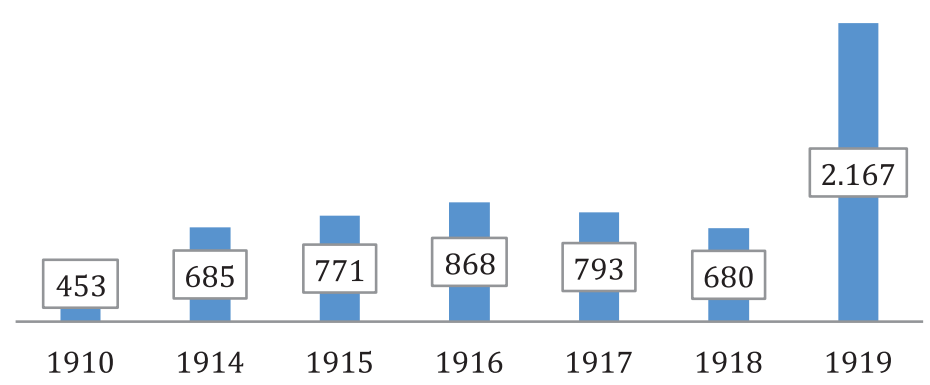

Figure 13 Export before, during and after war time (in million $f$ ) (Source: Korthals Altes, Vol. 12a, tables 2b and 6b)

In 1918, in some parts of the NI, food shortages occurred as a consequence of local harvest failure and a stop on rice exports in Indochina. Both circumstances resulted in a shortage of rice, the main staple of the indigenous population. When the sugar industry refused to relinquish land for cultivating rice, riots arose in Koedoes (Residency of Semarang) between Chinese and Javanese and eventually caused a number of casualties in addition to considerable material damage. ${ }^{18}$

The end of World War I brought with it a change in attitude in Western countries towards the right of self-determination. The American president Woodrow Wilson expressed this in his Peace Plan of 14 points. ${ }^{19}$ In his speech before both Houses of Congress he chose the ideal of democracy, representing the rights of free peoples everywhere to govern themselves. He opposed the ideal of imperialism, 'which seeks to dominate by force and unjust power.' In Great-Britain public opinion was ready to promote self-government in India. This led to the Government of India Act in 1919, an Act of Parliament of the United Kingdom, regulating expanded participation of the population in the government of India. The Act provided a diarchy, a dual form of government for the major provinces. In each province

16 W.L. Korthals Altes, Changing Economy in Indonesia, Volume 12a, General Trade Statistics, 1822-1940 (Amsterdam 1991) tables $2 \mathrm{~b}$ and $6 \mathrm{~b}$.

17 Because of the lack of price indexes for these years, volume 4 of Changing Economy follows the course of rice prices: If 1913 is put on 100, the index for 1918 would be 140. Unfortunately, the year 1919 is not reliable, because of severe food shortages in that year.

18 Van den Doel, Zo ver de wereld strekt, 279.

19 P.A.J. Caljé and J.C. den Hollander, De nieuwste geschiedenis (Utrecht 2000) 228-230. 
control of some areas of government was transferred to a Government of ministers answerable to the provincial Council. The 'transferred list' included agriculture, public health, public works and education. ${ }^{20}$

The ideals of C. Th. van Deventer inspired Governor-General J.P. Graaf van Limburg Stirum (1916-1921) to embark on the road towards self-determination of the Indonesian people. ${ }^{21}$ The new Governor-General had taken the place of the intended new nominee van Deventer (who died unexpectedly). Van Limburg Stirum was not only dedicated to effectuating this at local and regional levels, but at a national level as well, by creating a Volksraad (People's Council) with legislative power. The Minister of Colonies however, decided to implement less far-reaching political measures by aiming at more autonomy at the provincial level. In May 1918 the inauguration of the Volksraad took place. This Volksraad consisted of 39 members: the president and 19 members nominated by the Governor-General and 19 members elected by regional and local councils. The first Volksraad had only 15 autochthonous members. This inspired little enthusiasm with the indigenous population.

\section{Modernization of everyday life}

From 1910-1930, the population of Java and the Outer Islands increased from almost 37 million to more than 60 million inhabitants. ${ }^{22}$ Overpopulated Java received some relief by migration to the less populated islands such as Sumatra. Nevertheless, it had a hard job in looking after a population that increased from 29 to about 42 million people in this period. Furnivall attempted to depict the efforts and achievements of the Dutch to develop la richesse humaine for their subjects by referring to the main objectives of the Ethical policy: to stimulate the material prosperity of the people, to strengthen the native social order and to promote self-determination. ${ }^{23}$

In this time, the population was overwhelmed by phenomena such as cars, modern roads, bridges, Western hospitals and outpatient clinics, schools, water facilities, etc. New opportunities, but also threats were offered by the foreign rulers. Society became involved in a dynamic process that affected people's life in an unprecedented way. The impact of Western administrators, entrepreneurs, school teachers, doctors and missionaries on ordinary life was probably considerable in the regions where there had settled European colonists.

At first, the direct influence and impact of Western health care on the economic circumstances may have been small but gradually this additional branch of employment

20 Wikipedia, accessed March 2, 2015.

21 C. Th. Van Deventer, "Indië na den oorlog", De Gids 1915. Van Deventer was the leader of the Ethical movement in the Dutch parliament who had written a political testament under the title "the NI after the war". See Chapter 4 , $\$$ The ethical movement and legislation.

22 The figures of 1910 may have been estimated too low (were not based on a census). The 1930 figures were based on a precise census.

23 Furnivall, Netherlands Indies, 346. 
too furthered the prosperity of communities where health care facilities were established. Towards the end of the period, some 8,000 to 10,000 indigenous people were directly employed in hospitals and, indirectly, a substantial number of people depended on hospitals for their livelihood.

\section{Nationalist movements}

From the early 1900s, policy-makers were aware of the impact of their measures and tried to mitigate their consequences by embarking on an ethical path and issuing legislation to improve emancipation and self-determination. However, efforts to improve emancipation were often blocked by countermeasures, initiated by conservative European influences. The corresponding frustration and aversion sought and found an outlet in movements that strived for independence and self-determination.

Modern nationalist movements were emerging in many European colonies. In some parts of the archipelago it replaced the Indonesian armed resistance, which had manifested itself in areas such as Atjeh and Bali. The anti-colonial resistance was reinforced in some regions in the Netherlands Indies (For example in Sulawesi, where the Bugis and the Makassar people often stood up against the colonial forces). Even before 1914, the formation of nationalist associations was emerging.

In Chapter four there was mentioned the foundation of Boedi Oetomo, an initiative of pupils of the Stovia in $1908 .{ }^{24}$ Boedi Oetomo and the Sarekat Islam were both secular movements, which intended to develop Indonesia with Western methods. The word 'Islam' actually meant 'non-Dutch' and 'non-Chinese' and did not primarily refer to religious issues. This was the case with the modernist Islam movement called Moehammadyah, which was introduced via Egypt and the Sumatra region of the Minangkabau and spread to the Javanese Principalities in 1912. This movement focused on the education and wellbeing of the indigenous population and went through a period of substantial growth about 1921 . Throughout the archipelago the movement founded schools, basic hospitals, libraries and orphanages. It translated the Koran into the local language and held religious meetings. ${ }^{25}$ The impact of these protest movements was often negligible, but a few, such as the Sarekat Islam, quickly gained many followers.

Politically, the influence of international socialism and communism was growing. In 1914, the Indonesian Social-Democratic Association (ISDV) ${ }^{26}$ was founded by the revolutionary marxist H.J.F.M. (Henk) Sneevliet. The threat of revolution in Germany in 1918 and at home in The Netherlands caused the Sarekat Islam to become anti-capitalist and

\footnotetext{
24 The school that trained indigenous medical doctors, the dokter djawa. As a reminder of these early activities, the former school building now houses the Museum of the National Awakening.

25 W. van den Doel, Zo ver de wereld strekt, 275.

26 ISDV: Indische Sociaaldemocratische Vereeniging.
} 
revolutionary. The new Governor-General, J.P. van Limburg Stirum, influenced by rumours of revolution, promised the Volksraad co-partnership in his November-speech at the opening of the new Volksraad. This could be achieved by expanding the competences of this mainly advisory council to a body that participated in government and had budgetary control. At home in the Netherlands and in the Netherlands Indies, the Governor-General's announcement met with opposition and van Limburg Stirum had to scale down his promises. In the meantime, the expansion of the Volksraad's rights was achieved in the Constitutional reform of 1922.

In the eyes of the nationalists the rights of interpellation, amendment and initiative were only weak reflections of the real issues: the right to legislate and determine the budget. In 1927, the Study Club organized the PNI (Perserikatan Nasional Indonesia), which linked up all Nationalist movements and hardened its policy in the direction of non-cooperation. The PNI changed its name in Partai Nasional Indonesia in 1929 and gained considerable influence among the youth, mainly due to the public performances of Soekarno. In December 1929, the colonial authorities searched the offices of the PNI and arrested a number of PNI leaders, among whom Soekarno. His address for the defence: "Indonesië klaagt aan" (Indonesia accuses) was published in Dutch and in Malay. ${ }^{27}$

Occasionally, political organizations stimulated direct health care. Thus, Moehammadyah founded some maternity clinics and outpatient clinics, especially in the Batavia and Jogjakartan regions. At Soerakarta an ophthalmic clinic was opened and 3 outpatient clinics in the neighbourhood of Batavia. ${ }^{28}$ The female sub-organization of Boedi Oetomo (Wanita Oetomo) opened an outpatient clinic at Banjoemas. The Batavia department of the PNI started an outpatient clinic that was open every night and provided free care and medicines. These initiatives were organized in the years 1929 and $1930 .^{29}$

\section{HEALTH CARE 1910-1930}

After the Civil Medical Service had acquired its new status, separate from the Military Medical Service, the new Chief Inspector J. Schülein and deputy inspector W.Th. de Vogel set up the new organization. Its implementation could, in most cases, be achieved following the recommendations of the Reorganization Commission. Inspectors were assigned to three districts: West Java (1 inspector, 1 assistant inspector and 1 indigenous doctor), Central Java with the same amount of personnel and East Java, Madoera, Bali and Lombok together. In the Outer Provinces, the same organization continued as under military

27 W. van den Doel, Zo ver de wereld strekt, 290.

28 J. Peacock and E. Jung, "A century of helping shape a moderate Muslim democracy" NewsObserver.com, Jan.31, 2012.

29 Today, the Moehammadyah organization still exists and the other day it celebrated its centennial birthday at which occasion it evaluated the achievements. It reported to count 30 million members and as far as health care concerns: the organization established 47 hospitals, 217 clinics and 300 orphanages. In the field of education: it founded universities and 12,000 schools in Indonesia. 
supervision. This meant that the military first-ranking health officers were maintained in their function as acting regional chief of the Civil Medical Service.

Apart from that, the division in health districts remained as before with civilian doctors (in government service) or local private doctors (with allowances) or health officers (with allowances), having responsibilities for health regulations, supervision of vaccination and direct health care of civilian patients. After regulating the internal organization, tasks followed that had been neglected in the old situation, such as the providing of regular and reliable regional and local health statistics.

A drastic measure to be undertaken was the closure of all the hospitals for women with syphilis. This took place in 1911. Three other hospitals were closed in 1911: the two Chinese hospitals at Batavia and at Semarang and the Semaroong foundation at Soerabaja. The Chinese hospital at Batavia temporarily received a new function as auxiliary City Dressing Station. The Semaroong foundation was transformed into "Leprozengesticht Semaroong." ${ }^{30}$

Following 1910, medicine and health care developed vigorously in the new civil setting. The contours had been laid down by the 1906 Reorganization Commission and now the recommendations could be implemented contemporaneously with other innovations such as centralized company hospitals (East Coast Sumatra) and hospital networks (Jogjakarta). From 1910, all these developments led to an unprecedented expansion in hospitals, supported by successes of medical science.

\section{New accents in health care}

Quite some new diagnostic and therapeutic tools came to belong to the medical equipment of civil doctors and civil health care institutions. Two discoveries had an important impact on health in the Netherlands Indies:

- In 1910, the German chemist and physician P. Ehrlich (1854-1915) discovered together with his assistant Sahachiro Hata the chemotherapeuticum 606: salvarsan. He was looking for a drug that could cure sleeping sickness and after having researched more than 600 toxic elements, he found that element 606 proved to be effective against syphilis. It proved to be effective too against the bacterium that caused yaws. ${ }^{31}$

- Chr.Eijkman (1858-1930) discovered that beriberi was due to a vitamin deficiency in the diet of soldiers and convicts. ${ }^{32}$ His first article on the subject was part of the scientific annual report of his institute and carried the title "Polyneuritis bij hoenderen" (Polyneuritis with chickens). ${ }^{33}$ It was published in the Geneeskundig Tijdschrift voor

30 Koloniaal Verslag 1912, 135. Staatsblad van Nederlandsch-Indië 1911, no. 585 (NI Statutebook 1911 no. 585).

31 P. Ehrlich, "Abhandlungen über salvarsan", NedTijdschr geneeskd 56 (1912) 1396-1398.

32 Jansen, Het levenswerk van Christiaan Eijkman, 1858 - 1930 (Haarlem 1959).

33 C. Eijkman, "Verslag over de onderzoekingen verricht in het Laboratorium voor Pathologische Anatomie en Bacteriologie te Weltevreden, gedurende het jaar 1889," GTNI 30 (1890) 295-335.Transl.: Report on the investigations of the Laboratory of Pathological Anatomy and Bacteriology at Weltevreden during 1889. 
Nederlandsch Indië (GTNI) in 1890 and ultimately would lead to explaining the vitamin deficiency. But the paradigms of the past were still powerful and Eijkman did not apply the obvious conclusions of his research. So, the theory of avitaminose was developed by his successor, G. Grijns, and presented in four articles in the GTNI. ${ }^{34}$ Ultimately, this scientist became responsible for a conclusive therapy for beriberi. The food distribution in prisons, coolie camps and camps of convicts was adapted and beriberi gradually lost its threatening qualities.

These discoveries had a direct and immediate effect on the hospitals, which until then had hardly managed to take care of the many patients affected by these illnesses. Some hospitals for treating beriberi were closed down, others switched to new target groups of patients. All hospitals treating syphilis patients were closed for this function in 1911, but this was not caused by the introduction of salvarsan, but by a change in health policy.

Since the turn of the century, the new official attitude towards delivering health care to the civilian population had changed: legal titles to claim free health care became available for indigenous civil servants, retired civil servants, their families, widows and orphans. Private hospitals and auxiliary hospitals received Government subsidy on certain conditions. In addition to this, in 1924, the Civil Medical Service was renamed into Dienst der Volksgezondheid (Public Health Service). ${ }^{35}$ The accent on cure was reformulated with a stronger emphasis on positive and preventive health strategies. Its newly formulated mission included: health research, health statistics, control of infectious diseases, individual health care, soil improvement, assessment of drinking water, waste disposal and public housing. Civil health care was turned into a priority. Not only Europeans and indigenous civil servants had access to health care, but the entire indigenous community could benefit as well. This was a consequence of the Ethical Policy that proclaimed emancipation of the indigenous population. Yet, quite a few switches needed to be made. Answers had to be found on questions, such as: How to regulate all this in a decent and effective way and how to finance it? The paragraphs on hospitals hereafter will provide an answer to the question of organization.

Unfortunately, the funding that was available had to be used to a large extent in financing an anti-plague campaign. ${ }^{36}$

\section{Medical research and tropical medicine}

Scientific research became an important issue in health care, not only in The Netherlands, but in the Netherlands Indies as well. A few examples are: the research on beriberi and

\footnotetext{
G. Grijns," Over Polyneuritis Gallinarum I, II, III and IV", GTNI 41, 49, 50 and 51 (1901, 1909, 1910, 1911).

Staatsblad van Nederlandsch-Indië 1924, no. 576 (NI Statutebook 1924 no. 576). Royal Decree no. 48 of 13 October 1924.

36 According to the Begrooting van Nederlandsch-Indië voor de dienstjaren 1913 en 1914 (Budget NI 1913 and 1914); Werkelijke Uitgaven 1909-1912 (Real expenditure 1909 -1912), the real expenditure for the years 1909-1912 amounted to resp. $f 3.1$ million; $f 3.4$ million; $f 7.3$ million and $f 5.7$ million.
} 
hookworm (Laboratory Medan) and the institutes conducting research on the prevention of smallpox: The Parc-Vaccinogène (1891) and the Institute Pasteur (1894). ${ }^{37}$

In 1923, the Institute Pasteur moved to Bandoeng together with the Landskoepokinrichting. The former institute had a limited mission: it treated rabies and snake bites and produced sera and vaccines against cholera. Both institutes were housed in the same building and had one management. From 1911, the Military Medical Laboratory at Weltevreden was split into a Central Military Medical Laboratory and a Civil Medical Laboratory. Some years later, the civil laboratory acquired new premises. It was involved in the research of immunisation against the plague, filtration of river water and the spread of ankylostomelarvae. The Pathological Laboratory at Medan and the Central Military Laboratory joined the ranks of laboratories, which beside diagnostic work were engaged in medical research (See Figure 14).

In Chapter 4, there was mentioned the founding of the Nederlandse Vereniging voor Tropische Geneeskunde (1907). It was initiated by W.Th. de Vogel, who became Chief Inspector of the Civil Medical Service in 1913. Tropische Geneeskunde (Tropical Medicine) was a new specialty. It was the appellation of those studies and institutions that did research on prevalence, diagnostics, preventive and curative aspects of tropical diseases. Courses on tropical diseases were organized in the homeland in Amsterdam (1916) and Leiden (1920). In the Netherlands Indies, the military laboratory at Weltevreden, originally set up to study the beriberi problem, organized a course in tropical diseases. The establishment of such a course in a tropical disease environment looked more appropriate than somewhere in the Western world. All new health officers were required by their employer, the Department of War, to attend this course. This course started in 1901 but was closed in $1916 .{ }^{38}$ During these 15 years, 144 health officers and 44 civil doctors followed the course. ${ }^{39}$ It was closed because of the start of the two courses in Leiden and Amsterdam.

Medical doctors sent by missionary societies or getting employment with the NI Government were asked to attend courses in tropical medicine at the Dutch institutes. The nourishment of the Dutch institutes from the NI came by way of physicians who had served for some time in the tropics and had acquired experience in research laboratories in Batavia or on the East Coast of Sumatra.

In British India, a School of Tropical Medicine was founded in Calcutta. It was the only centre for postgraduate teaching in tropical diseases in India. The school had attached to it a special research hospital for tropical diseases. The institution owed its existence to the efforts of Sir Leonard Rogers, well-known by his work in connection with cholera,

37 Staatsblad van Nederlandsch-Indië 1902 no. 270 (NI Statutebook 1902 no. 270).

38 Staatsblad van Nederlandsch-Indië 1901 no. 89 en 1916 no. 741 (NI Statutebook 1901 no. 89 and 1916 no. 741 ).

39 G. Grijns, "Het Geneeskundig Laboratorium at Weltevreden". Transl. "The medical laboratory at Weltevreden." GTNI 57 (1917) 106-130. 


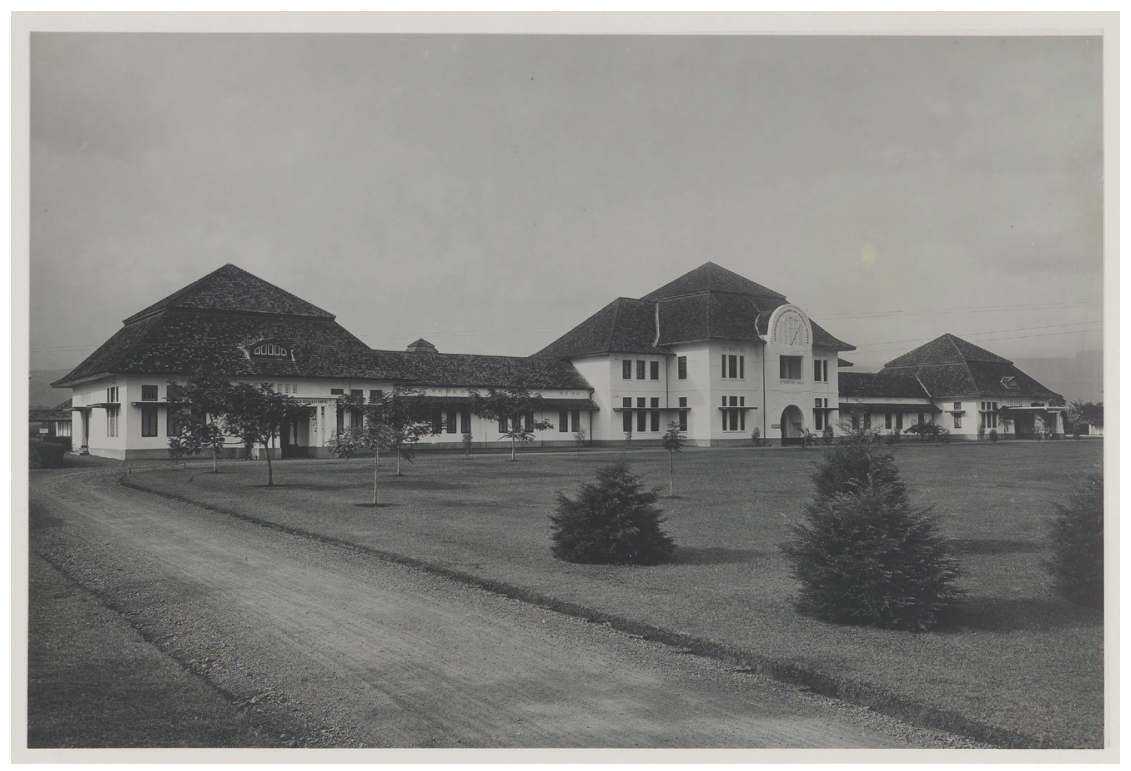

Figure 14 Parc Vaccinogene and Institute Pasteur at Bandoeng (Source: KITLV)

dysentery and other tropical diseases. The institute began to function from 1921 and enabled workers to carry on clinical research under strictly controlled conditions. ${ }^{40}$ In 1899, the Liverpool School of Tropical Medicine and the London School of Tropical Medicine had opened. ${ }^{41}$

In France, the school of tropical medicine was tied to military medicine. The main centre for tropical medicine studies in France was 'Le Pharo', the Military School of Tropical Medicine in Marseilles. ${ }^{42}$

In the United States no school of tropical medicine was founded. According to Anderson, Public Health, Military Medicine and Industrial Hygiene could be surrogates of colonial health service in the United States, but Tropical Medicine did not flourish in North America. In its colony, the Philippines, the laboratories of the Army Board for the Study of Tropical Diseases and the Manila Bureau of Science took to clinical research of the Plague, Cholera and the varying susceptibility to tropical diseases among the white colonizers and the Philippine population. ${ }^{43}$

40 E.W.C. Bradfield, An Indian Medical review 1938 (New Delhi, 1938) 228-231.

41 Nancy Leys Stepan, Picturing Tropical Nature (London 2001) 167.

42 Sokhieng Au, Mixed Medicines, Health and Culture in French Colonial Cambodia (Chicago 2012 ) 202.

43 Warwick Anderson, Colonial Pathologies, American Tropical Medicine, Race and Hygiene in the Philippines (London 2006). 
It was mentioned that initially, the Netherlands Indies had a local Laboratory carry out research on tropical diseases and offer local training facilities. However, it may be concluded that the main accent for training facilities in tropical diseases moved to research institutes in the mother country, as was the case with British India and French Indochina.

\section{Medical legislation on epidemics}

As mentioned before, an Ordinance regulated the prevention of infectious diseases from overseas. This Ordinance had been in operation for about 20 years and mentioned a limited number of diseases: Asiatic Cholera, smallpox and diptheria. ${ }^{44}$ In 1911, the plague had to be added. About the same time (1910s and 1920s), new legislation was made on contagious diseases in the Netherlands. This legislation regulated the medical supervision, publication, isolation, nursing and transport of patients. These regulations stipulated how the deceased should be buried and how to dispose of contaminated objects. The care of disinfection included expropriation, destruction and damage compensation.

In 1911, Governor-General A.F.W. Idenburg published the revised Epidemic Ordinance with measures against the plague, cholera, smallpox, diphtheria and typhoid fever. ${ }^{45}$ In the same year, Idenburg issued a new Quarantine ordinance. ${ }^{46}$ Consequently, an elaborate organization was set up to organize the fight against the plague: quarantine, obligatory reporting of new cases, instruction to health care professionals, instruction to administrators and the population, demolition of houses constructed with bamboo and the building of new wooden houses. All these measures placed a heavy burden on the health care budget. In 1917, the budget totalled $f 10.9$ million of which almost $f 5$ million went to dealing with the plague. The measures against the plague were far-reaching and successful in the first area hit by the plague, the province of East Java. Unfortunately, the plague was soon carried over, creating victims in the other Java provinces. Twenty years after its first arrival, 3,925 people died of the plague in West Java. In 1930, no mention is made of cholera cases.

In other colonial situations in Asia the plague had been a large problem some time before. In the Philippines, the first outbreak of the bubonic plague was in 1899. The American colonial administration issued a health ordinance in 1901. It was the basis of all subsequent ordinances and of the sanitary code. It was designed to control the spread of infectious diseases among the islands' population. The term infectious or contagious diseases' included smallpox, cholera, the plague, typhoid fever, yellow fever, leprosy, but not the insect-borne diseases such as malaria or dengue. ${ }^{47}$

44 Ordonnantie Gouverneur-Generaal C. Pijnacker Hordijk van 11 February 1892, Bepalingen ter voorkoming van het overbrengen van besmettelijke ziekten over zee in Nederlandsch-Indië (NI Statutebook no. 44 of $20^{\text {th }}$ February 1892: Regulations to prevent the import of infectious diseases from overseas).

45 Staatsblad van Nederlandsch-Indië 1911, no. 299 and no. 394.

46 Staatsblad van Nederlandsch-Indië 1911, no. 277, 302, 303, 323 and 528.

47 Warwick Anderson,"Immunization and Hygiene in the Colonial Philippines", Journal of the History of Medicine and Allied Sciences, 62 (2006)7-8. 
In British India the bubonic plague took an enormous death-toll during the years 1896, the year of its arrival and 1921. Arnold reports even some 10 million deaths. ${ }^{48}$ The Epidemic Diseases Act passed in 1897 as a measure to control the spread of the plague. It empowered provincial governments to make provisions for the inspection of corpses and the compulsory notification of all causes of and deaths from the plague. In other respects the Indian Government was hesitant to issue sanitary legislation. This was because of the cultural situation, which blocked the use of animal substances for vaccination. Smallpox vaccination and Leprosy Legislation suffered from this hesitancy, which was also partly dictated by fear of mutiny.

As for French Indochina, the Law on Health Care was issued in 1902 and contained a list of epidemics, that had to be reported on forms. In 1912, the lists comprised smallpox, cholera, the plague, typhoid fever, diphtheria, dysentery, yellow fever, meningitis, ophthalmic disorders children and polio. The first three threatened the population of Indochina fast any year during the period 1908-1922.

Comparing the different colonial situations for epidemiology, there is not much difference in the endemic and epidemic diseases that were prevalent in the four countries. Cholera and smallpox returned at more or less regular intervals. The plague arrived sooner in the other three countries. In the Netherlands Indies and French Indochina beriberi had a large health impact on soldiers and convicts, while in British India the black fever or kala azar made a lot of victims. In all the colonies malaria and leprosy were present and asked for health facilities. The policy of British India was marked by hesitant operations from fear of cultural opposition. The smallpox policy of the Netherlands Indies seemed most successful and the anti-plague measures had a positive outcome on the hygiene situation of the archipelago. The Americans in the Philippines focused on hygiene measures to bring down the risks for its soldiers and educationalists. They paid a lot of attention to the care of leprosy patients too. In French Indochina the military were primordial in health care and had a large say in the leading ranks of the Assistance Médicale Indigène (Indigenous Medical Service) until far in the $20^{\text {th }}$ century.

\section{Personnel: More training facilities for the workers}

As the number of hospitals, outpatient clinics and other health facilities quickly expanded, there was a growing need for doctors, nurses and other health professionals. Therefore, new schools and training facilities were started.

In 1911, the School for the training of indigenous doctors (Stovia) at Batavia had existed for 60 years. ${ }^{49}$ It may be recalled that the school was strongly connected with the Military

\footnotetext{
48 David Arnold, Colonizing the body, 238.

49 The Dokter djawa school (founded in 1851) was renamed in Stovia, School Tot Opleiding Van Inlandsche Artsen (School to train indigenous doctors). See chapter $2,19^{\text {th }}$ century, medical science and training.
} 
Medical Service during that period. The Chief Inspector Civil Medical Service decided to disentangle the Stovia from its military links and looked for a different location. New premises were found in the suburb Salemba, where in 1919 the new buildings of the CBZ (Centrale Burgerlijke Ziekeninrichting) would be situated..$^{50}$ In some 60 years, the school had produced 185 dokters djawa. ${ }^{51}$ Since this number was considered to be insufficient, it was decided to expand the training facilities for medical staff in the NI by founding a second school at Soerabaja. The new school was called NIAS (Nederlandsch Indische Artsen School) and opened in 1913. ${ }^{52}$ It had direct links with the well-equipped Centrale Burgerlijke Ziekeninrichting and the regional laboratory at Soerabaja, which both supplied knowledge, training facilities and tutors..$^{53}$

In the meantime, some members of the Volksraad insisted on the introduction of higher education in the Netherlands Indies. At Bandoeng, industrial and trading firms sponsored the foundation of a Technical University in 1920 and at Batavia a faculty of Law was initiated in 1924. Now the opportunities for higher education needed to be expanded to include medicine. The Medische Hogeschool (Faculty of Medicine) was founded in $1925 .{ }^{54}$

Clearly, there was a large demand for nursing professionals too. In essence, the training of nurses remained in the hands of hospitals. Some of the charity hospitals (Diaconessenhuis and missionary hospitals) recruited European nurses and had organized their own training facilities, but this was hardly sufficient for these hospitals themselves. In 1912, the function of mantri-nurse with the Civil Medical Service was officially announced..$^{55}$ The certified mantri-nurses received a monthly salary of $f 25$ to $f 50$ (after 15 years of service). In 1919, alongside bedside nursing a new development took place in professional nursing. Due to the massive shortage of medical personnel, the mantri-nurse $1^{\text {st }}$ class was introduced, who acted as a kind of curative professional under a physician's supervision and who more or less autonomously directed auxiliary clinics and outpatient clinics in the countryside. ${ }^{56}$ The Chief of the Civil Medical Service had to evaluate the quality of hospitals and could designate the hospitals that were allowed to train nurses. Therefore, he issued regulations for the training, requirements for examinations and licenses. Persons (of both sexes) applying for a training place had to meet minimum requirements of preliminary school attendance, good health and be of age. ${ }^{57}$ Not only government hospitals, but local and

\footnotetext{
50 On Java there were 3 so-called CBZ's: Central Civil Hospitals. At Batavia, at Soerabaja and at Semarang.

51 Hesselink, Healers on the colonial market, 221

52 NIAS: Netherlands Indies School of indigenous doctors.

53 The certified indigenous doctor could receive a monthly salary that varied from $f 70$ to $f 150$, depending on the experience (there were 4 raises of $f 20$, each after 3 years of practice).

54 C.D. de Langen," Indië voor de oorlog, het geneeskundig onderwijs in Indonesie". Transl.: “The Indies before the war, the medical education in Indonesia", Ned Tijdschr Geneeskd 92 (1948) 1582-1588.

55 Staatsblad van Nederlandsch-Indië 1912, no. 87 (NI Statutebook 1912, no. 87).

56 Rosalia Sciortino, "the multifariousness of nursing in the NI", 23-50.

57 Staatsblad van Nederlandsch-Indië 1920, no. 602, Regelen voor de opleiding van verplegings-en geneeskundig hulppersoneel. Transl. NI Statutebook 1920, no. 602, Regulations for the training of nursing and auxiliary medical personnel.
} 
private hospitals too could receive a training license and allowances for students. This central regulation had as a consequence that the Chief of the Civil Medical Service decided within the limits of the budget the numbers to be trained. From 1922, the public budget for the training of nurses was restricted to the Government hospitals. Local and private hospitals could continue trainings, if they met the requirements, but the costs of training and the supply of allowances for students had to be met by their own budgets. ${ }^{58}$ Besides doctors and nurses, health care needed several other professionals.

In 1902, the Landskoepokinrichting introduced a vaccination-course for people who wished to work as a vaccinator. If they succeeded in finishing the course, they could get an appointment as candidate-vaccinator.

The recruitment of trained personnel continued to be a matter of concern. Advertising for a job in the NI did not attract many doctors and nurses from The Netherlands. The lack of enthusiasm was furthered by trade unions who discouraged applying for a job abroad because of unsatisfactory labour conditions for nurses. Consequently, training in the NI was intensified and additional training facilities were introduced. Auxiliary laboratory and pharmacy personnel as well as dentists and pharmacist could hardly be obtained. In the 1920s, schools were founded to train pharmacy assistants, laboratory assistants and indigenous dentists.

In 1918, a preliminary course for Apothekersbedienden (pharmacy assistants) commenced. Later it was called the school for pharmacy assistants. The school delivered 134 licensed pharmacy assistants from its start until 1930. In 1930, 20 candidates were examined and received their license. ${ }^{59}$

In 1919, there was introduced a training of laboratory assistants. This training took place at the Centraal Laboratorium of the Dienst der Volksgezondheid (Medical Laboratory) at Batavia. Licenses required three years of training. The training differentiated between chemical analysts and bacteriological analysts. During the schoolyear 1929/ 1930, 11 students were enrolled for training. Beside this course, Laboratoriumhelpers were trained at the three CBZs. 179 students passed their examinations and were licensed in $1929 .{ }^{60}$ In 1928, the school for dentistry was opened in Soerabaja. In 1930, it had 42 trainees, most of them Chinese and half female. Training for indigenous dentists lasted five years. ${ }^{61}$ The authority to issue licenses for medical professions was assigned to the Civil Medical Service, later Public Health Service. ${ }^{62}$ These licenses were granted to medical doctors, pharmacists, dentists, midwives and pharmacy assistants. The agreement was that anyone who had received his professional license in The Netherlands could be admitted to

58 Staatsblad van Nederlandsch-Indië 1922, no. 549 (NI Statutebook no. 549).

59 Regeeringsalmanak 1920, Grondgebied en Bevolking, 317 and Indisch Verslag 1930, 388.

60 Government Decision of 31 July 1919 no. 6 (Supplement Statutebook nos. 9311 and 9312) announced this Leergang tot opleiding van analysten en controleurs volksgezondheid. See also Indisch Verslag 1930, 293.

61 Government Decision of 13 April 1928 no. 9 (Javaansche Courant no. 31).

62 Wijziging van het Reglement op den burgerlijken geneeskundigen dienst in Nederlandsch-Indië (Amendment of the Regulations on the civil medical service) by Decision of the Governor-General of 15 December 1910 (NI Statutebook, no. 649). 
exercise his profession also in the NI. It was also possible to acquire a NI license by passing some practical examinations. Extensive regulations were published for the schools of indigenous doctors.

In 1930, the professional workers in health care had increased to 3,538 (from 1,346 in 1910). By that time, the number of trainees (Laboratory assistants) and students (mantri nurse and mantri-nurse $1^{\text {st }}$ class) at the three CBZs totalled 873 and at the other hospitals: 1,158 . Taken together, professional workers and pupils, totalled 5,569 employees (See Figure 15).

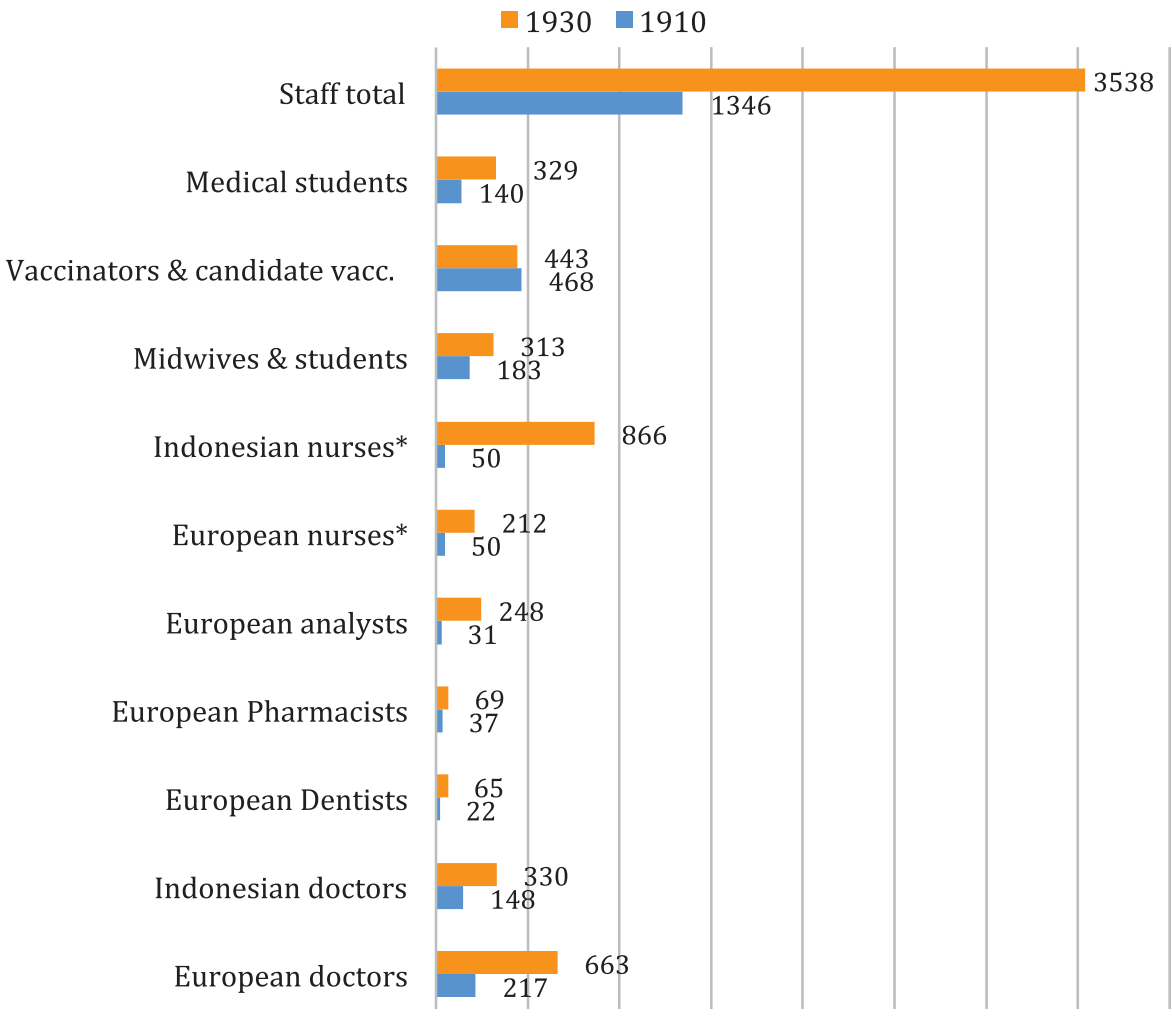

Figure 15 Professional Health Care workers Netherlands Indies 1910 and 1930 (Source: Figures 1910: KV 1911, Appendix S. Figures 1930: Indisch Verslag 1930, Appendix O)

*The numbers for nurses in 1910 have been estimated. Only a few government hospitals, Deaconess Hospitals and missionary hospitals employed professional nurses and organized training for these nurses.

The real number of people employed by the Civil Medical Service and by the hospitals of private associations may have been many times larger. This would have included: cooks, cleaners, gardeners, safety personnel, maintenance and administrative personnel. A rough 
guess, for 616 hospitals with on average a capacity of 93 beds, results in a total workforce of about 28,000 people. $^{63}$

\section{The patients: more hospital admissions}

Whereas intermittent fevers (malaria), cholera, smallpox, syphilis, beriberi and eye diseases were the dominant diseases of the late $19^{\text {th }}$ and first decade of the $20^{\text {th }}$ century (see Chapter 4, Figure 4), the Civil Medical Service faced new challenges in the second decade of that century, calamities that cost thousands of lives. Two epidemics, the plague and the Spanish flu, new to this part of the world, caused a lot of misery and high mortality. This had an enormous impact on the work and organization of the Civil Medical Service. New regulations were issued to meet these calamities and harsh measures were taken: a strict regime of quarantine and demolition of bamboo houses among others.

In 1911, the plague epidemic occurred and there was a large outbreak of cholera as well. In 1919, the Influenza pandemic caused extremely high mortality. In the next paragraph it will become clear what impact these epidemics had on normal life. The NI Government took far-reaching decisions as to how people had to comply with preventive measures.

Meanwhile, the trend of increasing hospital admissions continued after 1910. Partly, the increase in absolute figures was caused by population growth. It is not easy to differentiate within this tendency between the public that before had avoided hospitals and the patients who were admitted as a consequence of epidemiological patterns and improved diagnostics. Apart from cholera and the plague, hospitals admitted the same disease categories as before: especially malaria, venereal diseases, skin diseases and eye diseases. The number of patients with the diagnosis of beriberi was diminishing, while after 1910 the number of tuberculosis patients increased considerably. The absolute number of malaria cases and venereal diseases increased as well, while their relative importance fluctuated. The disease patterns that hospitals faced, may be illustrated by some figures from the years 1910 to 1930 (See Table 8). ${ }^{64}$

63 The average manpower per category of hospitals is mentioned in de Staat that accompanied art. 12 of the Regulations of the Head of the DVG of $30^{\text {th }}$ August 1927, no. 16553. Departing from the number of hospitals in 1930 (616), the average capacity (93) and non-professional manpower formations for hospitals in the range of 49-96 beds (32) brings a total of some 20,000 workers $(19,712)$. Taking the same Staat for professional workers (14) would lead to a number of 8,624 . Adding these rough calculations for the year 1930 would mean a health care workforce of more than 28,000 people $(28,336)$. On average, a hospital with a capacity of 93 beds, would count 46 employees.

64 Derived from KV 1911, Appendix S, KV 1920, Appendix O and Indisch Verslag 1930, Appendix O. 
Table 8 Reported hospital admissions 1910-193065

\begin{tabular}{lrrr}
\hline Category of Disease & $\mathbf{1 9 1 0}$ & $\mathbf{1 9 2 0}$ & $\mathbf{1 9 3 0}$ \\
\hline Malaria & 6,417 & 8,561 & 11,321 \\
Cholera & 662 & 234 & 0 \\
Smallpox & 1,157 & 379 & 175 \\
Beriberi & 2,503 & 437 & 1,390 \\
Venereal diseases & 3,691 & 6,026 & 12,707 \\
Other & 36,941 & 56,095 & 111,395 \\
\hline Total & $\mathbf{5 1 , 3 7 1}$ & $\mathbf{7 1 , 7 3 2}$ & $\mathbf{1 3 6 , 9 8 8}$ \\
\hline
\end{tabular}

The Indisch Verslag 1930 mentions the following additional diseases for that year, together with the mortality: ${ }^{66}$ (See Figure 16)

It is hard to evaluate the general condition of health in the archipelago. For some Outer Provinces the 1930 report mentions: the health situation is bevredigend (satisfactory): Atjeh, Tapanoelie, Billiton, Benkoelen, Palembang, Southeast Borneo and Celebes. The health situation is vrij gunstig (rather positive): West and East Sumatra, Bangka, West Borneo and Menado. The health situation liet te wenschen over (rather unsatisfactory): Moluccas, Timor, Bali and Lombok. For Java and Madoera the qualifications were more specific: "Though in general not unfavourable, for some regions rather unsatisfactory: in the regions Priangan, Indramajoe, Pekalongan, Tegal, Koedoes, Wonosobo and Kedoe many cases of the plague were reported. Bacillary dysentery was most reported for Jogjakarta like the year before and occasionally also in East Java. Typhoid fever was most reported for Batavia and increased in number for Soerakarta." ${ }^{67}$

Gardiner and Oey state that the quality of statistics was poor and not standardized. These authors report on the death rates in the period 1880 to 1940 , focusing on the diseases malaria, cholera and smallpox. Their conclusion is that control of major epidemics of cholera and malaria, along with virtual eradication of smallpox, was apparently achieved in the 1920s and that this must have had some impact on overall mortality. ${ }^{68}$

In 1916, the Doodschouwordonnantie (Ordinance on death certificates) was issued. In essence, the ordinance was destined for the indigenous population and foreign Asians and prohibited the burial of deceased persons in absence of a written certificate stating the cause of death,

65 It should be noted, that the number of hospitals involved in these statistics was limited to the government hospitals and some missionary hospitals. The large body of company hospitals, other private hospitals and military hospitals is not represented in these figures. Besides, the selection of diseases seems not well chosen: some hardly had a significant number and the large undifferentiated category Other represents $72 \%$ to $81 \%$ of the total.

66 Chapter III, De Sociale Toestand, $\$$ E. Gezondheidszorg, p. 379 (Social Situation, Health care).

67 Verslag van bestuur en staat 1930, 7, 11-14, 16, 18 - 21, 24, 26- 28.

68 P. Gardiner and Mayling Oey, "Morbidity and mortality in Java 1880-1940: The evidence of the colonial reports", in: Norman G. Owen, ed., Death and disease in Southeast Asia (Oxford 1987) 70-91. 


\section{- Died Admissions}

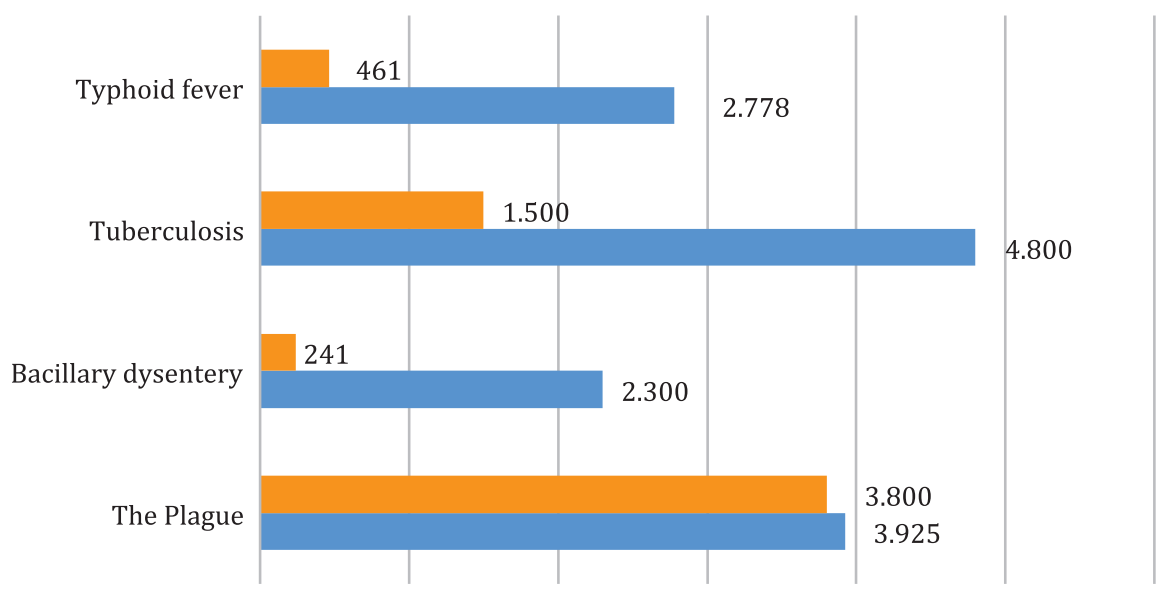

Figure 16 Some diseases and mortality, 1930

signed by an authorized person. This facilitated an improvement in mortality statistics. ${ }^{69}$ Mortality statistics for the years 1912,1918 and 1924 for the provinces of Java are presented in Table 9. In 1918, mortality doubled because of the Spanish flu. The population figure has been estimated to be 34 million; hence, the crude mortality rate for 1918 is $37 \%$.

Table 9 Mortality $1910-1930$ in the provinces of Java $a^{70}$

\begin{tabular}{lrrr}
\hline Province & $\mathbf{1 9 1 2}$ & $\mathbf{1 9 1 8}$ & $\mathbf{1 9 2 4}$ \\
\hline West Java & 150,604 & 219,089 & 167,996 \\
Central Java & 218,213 & 426,354 & 227,943 \\
East Java \& Madoera & 232,089 & 496,140 & 195,344 \\
Principalities & 58,662 & 125,637 & 60,285 \\
Total Java & 659,568 & $1,267,220$ & 651,568 \\
\%o population & $21 \%$ \% & $37 \%$ \% & $18 \%$ \\
\hline
\end{tabular}

Source: Changing Economy, vol. 11, tables 5, 6a.2, 6b.2, $6 c .2$ and10.

69 Ordinance of 27 September 1916 (NI Statutebook no. 612). By Governmental Decision of 3 March 1917 the ordinance had been declared bound for the cities of Batavia, Semarang and Soerabaja.

70 P. Boomgaard and A.J. Gooszen, Changing Economy in Indonesia, Volume 11, Population Trends 1795-1942 (Amsterdam 1991), Tables 5, 6a.2, 6b.2, 6c.2 and 10. 


\section{Financial accessibility of hospitals}

In 1906, the Government of the NI issued regulations to subsidize private indigenous hospitals and auxiliary hospitals. ${ }^{71}$ These regulations were adapted at regular intervals for development of prices and wages. A substantial adaptation took place in 1928. In these new regulations, issued by Governor-General A.C.D. de Graeff (1926-1931), there was regulated the substitution of European staff by indigenous staff. ${ }^{72}$ In 1917, a financial provision (allowances) had been arranged by a decision of Governor-General J.P. van Limburg Stirum (1916-1921) for regions and municipalities, which founded or maintained their own hospitals. ${ }^{73}$ These allowances facilitated the decentralization of public hospitals, as they were almost equivalent to the ones that had been issued in 1906 and 1928 for private not for profit hospitals.

In the Rules concerning staff formation and patient billing in public civil hospitals, it was stated that anyone might be admitted to a public hospital, as long as the monthly income remained below $f 250$ for persons without a household or below $f 400$ for persons belonging to a household with a maximum of 3 children or below $f 500$ with a household with more than 3 children. ${ }^{74}$ Did this mean that in government hospitals there was no place for persons earning a higher income? In fact, it did. On the other hand, the medium and higher income groups (mostly Europeans and Chinese people), often had recourse to a European hospital (in large cities e.g. Deaconess Hospitals, or in the countryside to the separate pavilions or hospitals that many companies established for their European personnel). The public civil hospitals, like their predecessors, the Inlandsche hospitals, were established for the poor, destitute and low-income population and therefore had a maximum of three classes of nursing facilities: $2^{\text {nd }}, 3^{\text {rd }}$ and $4^{\text {th }}$ class. However, even in 1927, most public civil hospitals had only $4^{\text {th }}$ class nursing facilities, so in most cases (52 out of 84 hospitals) patients had no choice at all. There were only 9 hospitals that offered accommodation in all three classes. The first class nursing facilities were to be found only in private clinics or in European hospitals.

Financing public hospitals was simple: all public hospitals had their deficits reimbursed by the Treasury. Financing company hospitals was about the same: the company or a group of companies joined in financing the total hospital expenditure. For missionary hospitals and other private charity hospitals about $75 \%$ to $90 \%$ of their expenditure was subsidized by the NI Government.

71 Staatsblad van Nederlandsch-Indie 1906, no. 276 (NI Statutebook 1906, no. 276).

72 Staatsblad van Nederlandsch-Indië 1928, no. 540 (NI Statutebook 1928, no. 540), "Nieuwe subsidieregeling voor particuliere ziekeninrichtingen voor on- en minvermogenden" (New regulations to subsidize private hospitals for indigent persons).

73 Staatsblad van Nederlandsch-Indië 1917, no. 229 (NI Statutebook 1917, no. 229), "Ordonnantie, houdende regelen voor de verleening van tegemoetkomingen uit 's Lands Kas aan gebiedsdeelen met eigen geldmiddelen ten behoeve van hunne ziekeninrichtingen" (Regulations to subsidize local hospitals).

74 Supplement NI Statutebook 1927, no. 11446. About levels of salary: European nurses earned in 1928: $f 125$ a month; a European doctor $\mathrm{f} 300$ to $\mathrm{f} 600$ monthly; an indigenous doctor: $\mathrm{f} 200$ to $\mathrm{f} 300$ monthly; a mantri-nurse: $\mathrm{f} 30$ monthly. 
It would be interesting to know how many patients really paid their hospital bills. To prevent default of payment, the hospital administration charged the patients in advance for 14 inpatient days. If they had paid too much, they were credited on the patient's discharge from the hospital. If the patient was poor and proved (to the satisfaction of the administrator) to be without means, he could be nursed for free in class $4 \mathrm{~b}$. The normal rates were $\mathrm{f} 6$ for $2^{\text {nd }}$ class; $f 3$ for $3^{\text {rd }}$ class and $f 1.50$ for $4^{\text {th }}$ class nursing.

The following groups were exempted to pay for hospital services:

a. behoeftigen (poor people);

b. prisoners and persons with a verdict;

c. patients to be judged in a penal case (treatment demanded by police or judge);

d. military or police force.

It is difficult to trace how much payment actually was received from patients. Looking at the three most promising income categories: inpatient bills, outpatient bills, medicines for outpatients and neosalvarsan injections (to treat yaws), for the whole group of public hospitals all four together yielded $f 2.8$ million in 1929. In that year the total expenditure of the Public Health Service amounted to $f 20.3$ million.

This underlines the remarks in the Introductory chapter concerning demand and supply and the market-mechanism: as only about $10 \%$ of the hospital services were paid for by patients, the price-setting mechanism could hardly have any noticeable effect on the course of demand and supply of hospital services.

\section{Remaining role of military hospitals}

Although the number of private and government hospitals and outpatient clinics grew significantly, part of the civilian population relied on the presence of military health care facilities in their neighbourhood. Moreover, some military doctors took initiatives to improve the health care of the population in their capacity of Eerstaanwezend Officier van gezondheid (First ranking health officer) for a region that was deprived of civilian doctors. In 1910, there were still quite a few health officers: 11 for Java and 35 for the Outer Provinces. By 1930 this number was strongly reduced to five (three for Sumatra and two for Borneo). Nevertheless, the NI army consisted mainly of indigenous soldiers. Both they and their families profited from the health care provided by the army. The number of persons treated in military hospitals varied from 25,000 to 30,000 per year during the years 1910 to 1920 . In the last years of this period, the numbers decreased to about 18,000 . These figures represent an extremely high disease rate of almost $50 \%$. The greater part (some $25 \%$ ) had to do with treatment of venereal diseases and malaria $(16 \%){ }^{75}$ 
After 1910, the greater part of military hospitals could be found in the Outer Provinces. The military had three first class hospitals on Java, located at Weltevreden, Tjimahi and Magelang. In 1930, a total of 76 military hospitals existed in the following regions (see Figure 17). In the previous chapter the development of military hospitals was traced from 1867 through 1890 to 1910 . In 1890, there were 3 main hospitals, 29 garrison hospitals and 53 infirmaries. Looking at the figures for 1929, the total number of military hospitals and infirmaries amounted to 76, most of which were located in areas known for indigenous troubles and uprisings. Less than one third of the military hospitals could be found on Java (20), while 56 hospitals and infirmaries were maintained in the Outer Provinces, of which 16 were in the region of Atjeh. ${ }^{76}$ The total manpower for these military health facilities was 1,575, of which 215 belonged to the category officers (180 medical doctors, 21 pharmacists and 14 other). Compared to the 1910 figures, the number of military doctors had increased by almost $50 \%$.

\section{STRONG ADVANCE OF CIVIL HOSPITALS}

Two decisions created favourable conditions for future development of civil hospitals: The decision of the Dutch parliament in 1901 to introduce ethical principles in the colonial policy and the decision in 1910 to separate military and civilian health service.

Both of these decisions inspired the responsible health authorities (directors and inspectors of health) to encourage new initiatives. Important were the subsidy regulations of 1906 . In 1911 and 1916, when the regulations were adapted, these regulations provided increased budget and gave more financial security for a growing number of private hospitals. As mentioned before, in 1928, new regulations were formulated and issued by GovernorGeneral A.C.D. de Graeff (1926-1938).$^{77}$ From then, a financial provision was established for regions and municipalities that had founded or maintained their own hospitals. This facilitated the decentralization of public hospitals. ${ }^{78}$ The hospitals involved were called Gesubsidieerde locale ziekeninrichtingen (Subsidized local hospitals). In 1930, these totalled $12 .{ }^{79}$ The chances created by these regulations were eagerly used. Regions that thus far had been deprived of any health care facility, saw the establishment of new outpatient clinics or hospitals.

The paragraph on personnel showed the efforts taken to extend the professional capacity and the outcome of these efforts (See Figure 15, in the paragraph Personnel). The measures

76 Verslag van bestuur en staat 1930, Annex O, Table 1.

77 Staatsblad van Nederlandsch-Indië 1928, no. 540, "Nieuwe subsidieregeling voor particuliere ziekeninrichtingen voor on- en minvermogenden" (NI Statutebook 1928, no. 540, New subsidy regulations for private hospitals for indigent patients).

78 Staatsblad van Nederlandsch-Indië 1917, no. 229, "Ordonnantie, houdende regelen voor de verleening van tegemoetkomingen uit 's Lands Kas aan gebiedsdeelen met eigen geldmiddelen ten behoeve van hunne ziekeninrichtingen”, NI Statutebook 1917, no. 229 (Regulations for income dotations to local hospitals).

79 Financed according to NI Statutebook 1917, no. 229: Municipal hospitals: Bandoeng, Soekaboemi, Cheribon and Pasoeroean. Provincial hospitals: Garoet, Tasikmalaja, Indramajoe, Banjoemas, Tegal, Koedoes and Pamekasan. Local council of KomeringHilir: one hospital. 


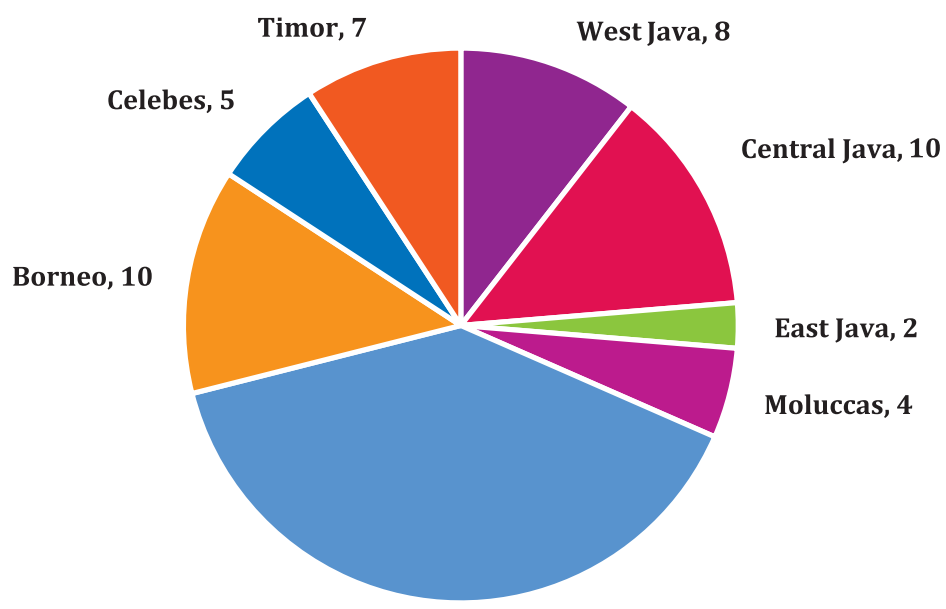

Sumatra, 30

Figure 17 Location military hospitals, 1930

were successful and led to a doubling of professionals for the Outer Provinces and to a tripling of the available staff for Java in twenty years' time. Nevertheless, it was felt that other measures were needed to rationalize the organization of health care. Experiments on the training of desa healers and doekoens mata (indigenous eye doctors) had to be abandoned because of vehement criticism, but the training of mantri-nurses $1^{\text {st }}$ class, who could take care of outpatient clinics and auxiliary hospitals under supervision of a hospital doctor, was put into practice and was strongly recommended by both missionary doctors and the chief inspector of health. (See the Djokja experiment).

Apart from measures in the field of recruitment (training facilities) and financing (subsidies for private charity hospitals and for local public initiatives), the expansion of hospitals benefited from the infrastructure of a well-ordered settlement of medical districts (Ressorten) that had existed for some time and that was reinforced by the Reorganization Commission. The essence of this system was that each civil department (assistant residency) was divided into one or more health districts, depending on the size of the department and population density. The Reorganization Commission had recommended to establish at least one small hospital or nursing station (about 10 beds) in each health district and as this might overburden the NI budget, to promote the financing of these facilities by local communities or by European private companies that might see the benefit of giving care to employees and their families. The medical staff within these health districts was charged with a variety of responsibilities, ranging from keeping regular outpatient clinics to supervision of vaccination and to taking care of medical facilities in prisons. Around 1910, the number of practicing medical doctors and indigenous doctors was 218 . This number 
was assigned to a city, an Assistant-Residency, a Residency or an institution. The number for each medical district varied from 1 person (medical doctor or dokter djawa) to 16 (Batavia). ${ }^{80}$

From 1910 to 1930, hospitals went through a process of expansion, of improvement in material equipment and buildings and in the quality of personnel. However, the small number of doctors kept hindering the development of well-equipped and well-staffed hospitals. So, many regions and towns had to be content with small auxiliary hospitals, which had only one part-time physician or dokter-djawa. Apart from the large Central Government Hospitals (CBZ), a few large missionary hospitals and some big central plantation hospitals, the greater part of the hospitals consisted of hospitals in the subsidy categories I (10-25 beds) or II (26-75 beds). The greater part (57) of the 73 hospitals that were subsidized in 1925 were small hospitals. ${ }^{81}$

The total numbers of public hospitals (CBZ, GBZ and Municipal hospitals) initially decreased from 78 (in 1910) to 63 (in 1920) and subsequently increased to 92 to become stabilized by 1930 (see Table 10).

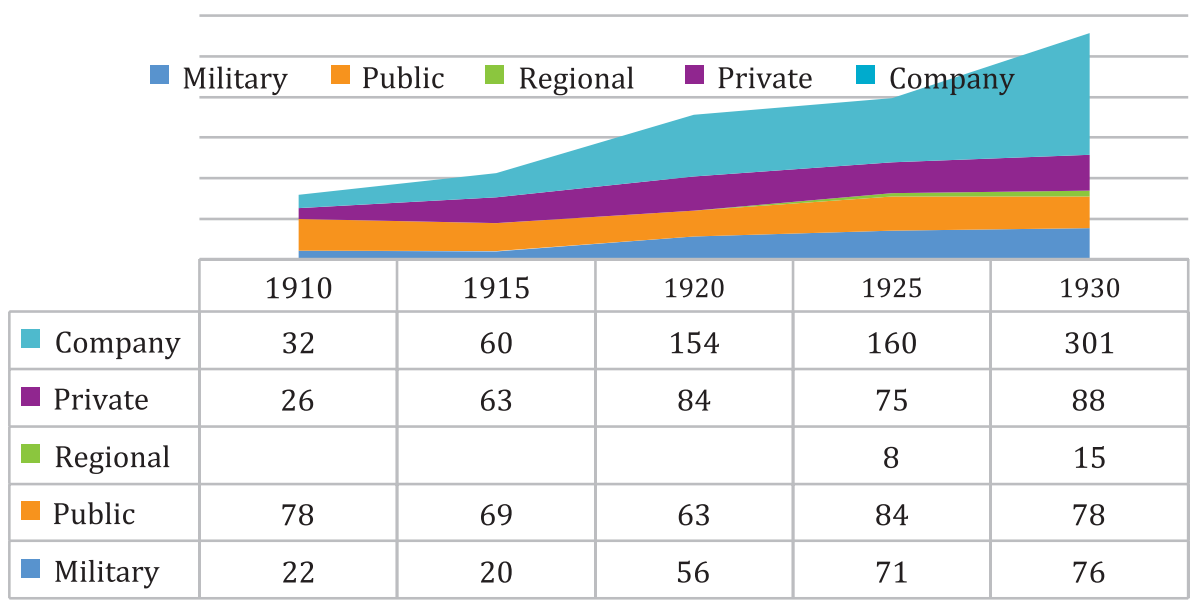

Table 10 Type of hospitals by year (Source: Koloniale Verslagen 1911, 1916, 1921, 1926 and Indisch Verslag 1930)

However, there is a flaw in these figures: the numbers for the Government Civil Hospitals between 1915 and 1920 did not include the hospitals for syphilitic patients, which partly continued as Inlandsche ziekenhuizen. The development of fewer central government and more regional hospitals reflects the influence of the decentralization policy. In the words

80 Report Reorganization Commission, Chapter III.

81 Only 3 were labelled III (76-120 beds), 8 were labelled IV (121-170 beds) and 5 were labelled V (171-220 beds). 
of the KV 1918: "Instead of promoting the establishment and exploitation of hospitals by the Government, private and municipal (regional) initiatives shall be stimulated to engage in establishment and upkeep of hospitals. Regulations to subsidize private indigenous hospitals will become available for that purpose." ${ }^{2}$

From 1921, the Civil Medical Service created three additional ways to involve third parties in the upkeep of hospitals. ${ }^{83}$ These three methods were:

- notarial agreement by which a hospital association takes over a government hospital by paying rent and by being responsible for government patients;

- notarial agreement in which the government participates in a hospital founded by an association;

- Notarial agreement in which the NI government and a private association participate in a new hospital, yet to be founded.

Concerning regional allocation: as we saw with the economic activities that the situation improved for the regions outside Java: more health provisions, hospitals and outpatient services were initiated in the Outer Islands. In 1910 the ratio Java: Outer Provinces for hospitals was: 78 (Java): 83 (Outer Provinces). This almost equal number changed in favour of the Outer Provinces. In 1930, Java counted 198 hospitals and the Outer Provinces 359.

\section{GENERAL HOSPITALS FOR CIVILIANS}

Chapter 4 divided the general hospitals into two main categories: public and private hospitals. The public hospitals fell under the jurisdiction of central, local or regional government. Employees in these hospitals were civil servants. Initially, the largest category was formed by the Government Civil Hospitals. Originally, these had been a so-called inlandsch ziekenhuis or a combination of an indigenous hospital and a former hospital for patients with syphilis. From the mid- 1920s this category was reorganized into municipal, regency or provincial hospitals.

Within private hospitals, a subdivision was introduced into private company hospitals and private charity hospitals. These divisions will be maintained in this chapter and the next.

82 Koloniaal Verslag 1918, 129.

83 "Notarieele overeenkomsten met rechtspersonen inzake ziekenhuisbehandeling. Modelcontracten." Bijblad Indisch Staatsblad no. 9786 of 26 January 1921 (Agreements with third parties to arrange for hospital treatment, Supplement NI Statutebook 1921, no. 9786). 
Represented schematically:

\begin{tabular}{lllll}
\hline \multicolumn{2}{c}{ Public hospitals } & & \multicolumn{2}{c}{ Private hospitals } \\
\cline { 1 - 2 } Government & Regional & & Charity & Company \\
Military & Municipality & & Missionary & Plantation \\
Central & Regency & & Deaconess & Mining \\
Local & Province & & Salvation Army & Industrial \\
& & & Other & Other \\
\hline
\end{tabular}

\section{Public Hospitals}

Comments by medical inspectors, such as G.W. Kiewiet de Jonge, indicated deplorable conditions in the seven main Government hospitals. ${ }^{84}$ In her final report, the Reorganization Commission of 1906 expressed the same opinion and added 17 reports about conditions in civil government hospitals from 1903 to 1906. In his last chapter, Schoute mentioned that the military hospitals were the best equipped and that the civil hospitals did not receive much attention during the last decennia of the $19^{\text {th }}$ century. He expected that a complete renaissance of civil hospitals in NI would be needed. This would involve not only the exterior outlook and architecture, but also the social and scientific function. ${ }^{85}$ After 1910, these reports and recommendations had the desired effect.

\section{Central Government Hospitals}

In 1919, the buildings of the City Dressing Station at Batavia were abandoned and the cities of Semarang and Soerabaja were given the prospect of new central civil hospitals, when the new Central Government Hospital at Salemba (Batavia) was opened.

The new hospital at Salemba (Batavia) replaced the City Dressing Station at Glodok that dated from 1845. The Glodok hospital would continue to care for sick prisoners and patients with contagious diseases. ${ }^{86}$ The new hospital was built following the prevailing pavilion design. This type of architecture was recommended for all tropical hospitals. ${ }^{87}$ According to the report of a journalist, who attended the opening ceremony, the size of the buildings and the compound of the new hospital made a huge impression. Although few people had noticed the preceding construction activities, as these took place in a rather inaccessible place in the jungle, the result seemed to be astonishing. The new building was constructed

\footnotetext{
84 The City Dressing Station of Batavia, Semarang and Soerabaya, the Auxiliary City Dressing Station of Batavia and Semarang, the Chinese Hospitals at Batavia and Semarang were initially counted among the main government hospitals.

85 Schoute, "De geneeskunde in Nederlandsch-Indie", 1467-1473.

86 Koloniaal Verslag 1920, 218.

87 We refer to the report of Walland and van der Elst, the two authors who wrote about the most suitable architecture at the occasion of the building of the psychiatric hospital at Buitenzorg. See Chapter 3.
} 
next to the new Stovia building on a spacious terrain. ${ }^{88}$ The director A.A. Hulshoff and some of his staff, showed the visitors around the compound, visiting pavilions, administrative and technical services. The visitors' impression was one of an enormous size: the first floor corridor alone measured some 1000 metres. Visitors walked through the many departments that make a modern hospital and saw wards, kitchens and gudangs (storerooms), a water pumping-station, offices, waiting rooms, engine-rooms and lavatories (see Figure 18).

The other two central government hospitals of Soerabaja and Semarang were established at the same slow pace as the CBZ at Salemba, which had waited 25 years after the initial decision to rebuild it had been taken. The new CBZ at Semarang was opened on 9 September 1925. About $f 2.5$ million had been invested in the buildings and premises. The new Soerabaja CBZ was only established some years before WWII and then the new occupants had to compete with the Navy about the final function of the new buildings.

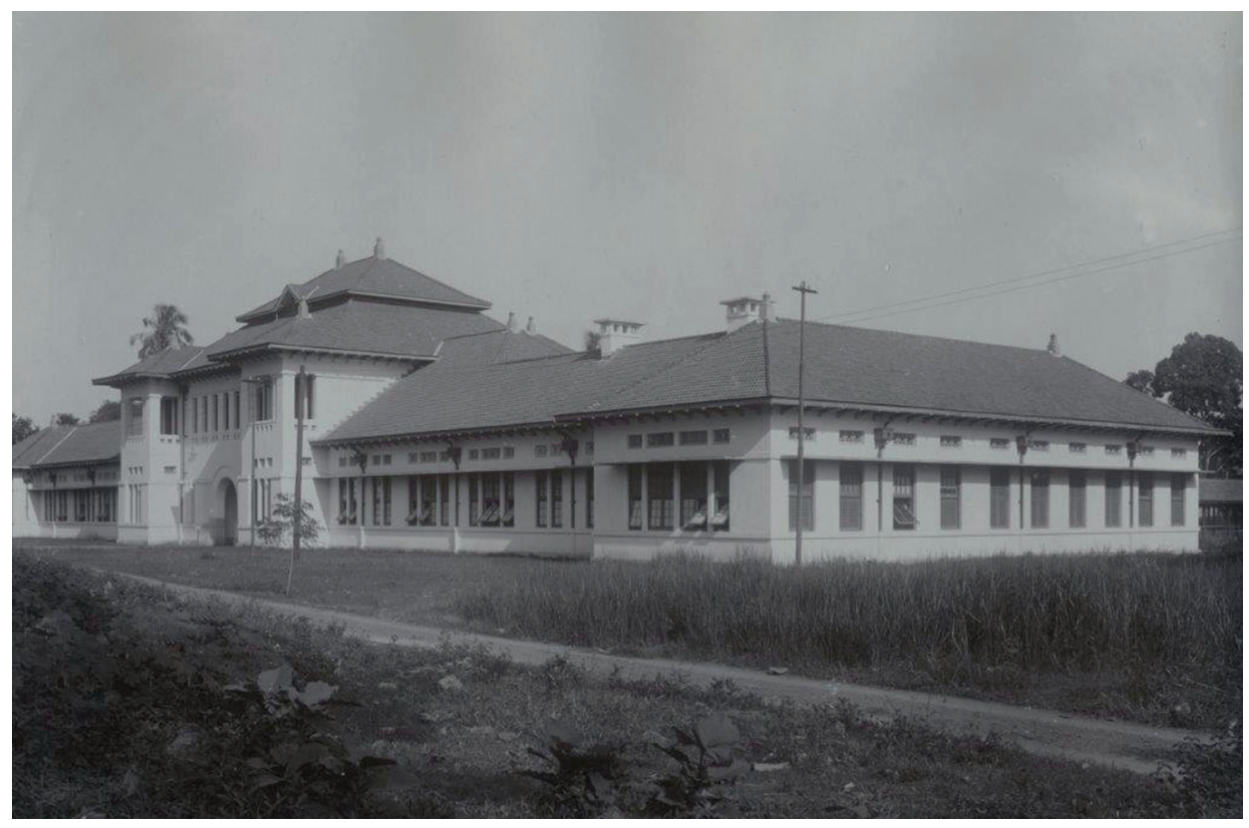

Figure 18 The new Central Government Hospital at Salemba (Source: KITLV)

In order to modernize the organization structure of the central government hospitals the function of stadsgeneesheer (city doctor) was repealed for the 3 cities on Java. ${ }^{89}$ These city physicians had been responsible for the health care of the population and the management

88 According to the local Newspaper, Nieuws van den Dag voor Nederlandsch Indië of Monday $15^{\text {th }}$ December 1919.

89 Staatsblad van Nederlandsch-Indië 1914, no. 786 (NI Statutebook 1914, no. 786). 
of the hospitals. From 1914, they became medical directors of the central government hospitals and their competences and responsibilities were laid down in new instructions. ${ }^{90}$ By 1930, the number of occupied beds of the 3 central civil hospitals (CBZ) had increased to 2,051 with a joint budget of $f 2.4$ million (see Figure 19).

Soerabaja Semarang Batavia

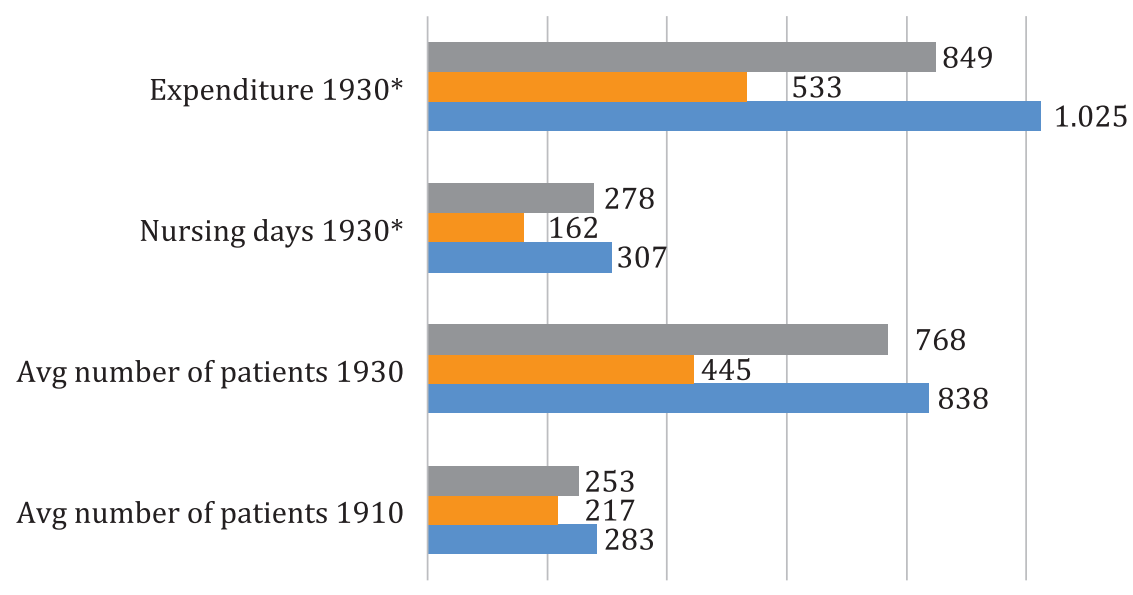

Figure 19 Statistics CGHs of Batavia, Semarang and Soerabaja 1910 and $1930\left(^{*}(000)\right.$ Source: KV 1911 and Indisch Verslag 1930)

\section{Government Civil Hospitals (GCHs) ${ }^{91}$}

Formerly, the indigenous hospitals were often housed in prisons or joined hospitals for women with syphilis. Mostly, these were rather small and primitive institutions. After 1906, the government tried to upgrade some of the hospitals by regulating supervision, personnel and pay and by supplying money for new buildings and reconstructing old ones. The overall position of these hospitals had been far from clear. Sometimes the authorities could not tell which hospital was a general indigenous hospital and which was a hospital for women with syphilis.

From 1906, hospitals could apply for subsidy and in order to meet the subsidy requirements, certain criteria were checked. The regional and local administrators (Residents and Assistant-Residents) were responsible for the quality of buildings, personnel, equipment and nourishment of patients. In the 1920s, the aim of the Civil Medical Service was to

90 Bijblad Staatsblad van Nederlandsch-Indië 1914 no. 8658 (Supplement NI Statutebook 1914, no. 8658).

91 The Dutch name Centrale Burgerlijke Ziekeninrichting is abbreviated to CBZ. 
improve the quality by enlarging the staff and by attracting more qualified personnel, thus trying to get rid of the bad image these institutions had as former hospitals for prisoners and prostitutes. From then on, the situation became clearly structured: the ones that did not meet subsidy standards soon had to close and the remainder either became institutions enjoying government financing or chose to keep a private regime and had to apply for public support annually. ${ }^{92}$ In the 1910 s a lot of hospitals for syphilis were closed or continued as an indigenous hospital. The publicly financed indigenous hospitals gradually were upgraded to Government Civil Hospitals. Later on, some were closed to change place with hospitals owned by lower public administrations such as provinces and municipalities. During the 1920s about 18 indigenous hospitals were closed, sometimes after they had been converted to Government Civil Hospitals.

In 1919, seven municipal hospitals were under construction: at Bandoeng, Soekaboemi, Garoet and Cheribon on Java and at Medan and Palembang on Sumatra and Makasser on Celebes. Missionary societies and similar organizations took over some of the remaining hospitals. By the end of 1930, the number of GCHs on Java and Madoera was 46 and for the Outer Islands: 31 , together having a bed capacity of 4,337 and an average daily number of patients of 3,295 (see Table 11).

Table 11 Statistics of all Government Civil Hospitals 1930

\begin{tabular}{llllll}
\hline $\begin{array}{l}\text { Bed } \\
\text { capacity }\end{array}$ & $\begin{array}{l}\text { Average } \\
\text { Number of } \\
\text { patients }\end{array}$ & $\begin{array}{l}\text { Nursing } \\
\text { days }\end{array}$ & $\begin{array}{l}\text { Average } \\
\text { Occupancy } \\
\text { Rate }\end{array}$ & $\begin{array}{l}\text { Average } \\
\text { Costs per day }\end{array}$ & Total costs \\
\hline 4,337 & 3,295 & $1,202,894$ & $76 \%$ & $f 1.14$ & $f 1,381,429$ \\
\hline
\end{tabular}

Source: Indisch Verslag 1930

Taken together, all general government hospitals had a joint bed capacity of almost 7,000 beds and a combined budget of some $f 3.8$ million in 1930. The total Public Health Service budget for that year amounted to $f 26$ million. ${ }^{93}$

\section{Municipal or provincial hospitals}

The second type of public hospitals for civilians (not run by the NI Government), were those managed by municipalities or other regional authorities. From 1917, the Central Government itself no longer promoted the establishment of hospitals, but encouraged initiatives by lower public administrations. ${ }^{94}$ These public hospitals received financial allowances similar to private

92 Government Decision 13 May 1927 no. 32 (J.C. no. 39) approves the closure of the GBZs at Poerworedjo, at Gombong, at Magelang, at Poerwokerto, at Blora and at Salatiga as of the $1^{\text {st }}$ October 1924.

93 Begrooting Nederlandsch Indie 1930, Ch. II, Departement van Onderwijs en Eeredienst (Budget NI Department Education and Worship).

94 Staatsblad van Nederlandsch-Indië 1917, no. 229 (NI Statutebook 1917, no. 229). 
foundations. An ordinance of 2nd June 1917 arranged for territories with budgetary means to finance hospitals. This occurred in accordance with the decentralization politics. Hospitals that were managed by provinces, municipalities or other independent communities received subsidy (called Tegemoetkoming) based on the arrangements for private hospitals. The shift from the central public administration to local communities took place in a rather gradual way. By 1930, only 11 hospitals on Java and 4 in the Outer Provinces had been founded by municipalities and provinces. Including the ones mentioned in the previous section (7 municipal hospitals) these hospitals were:

- 6 provincial hospitals on Java: at Tegal, Banjoemas and Koedoes (Central Java), at Tasikmalaja and Indramajoe (West Java) and at Pamekasan (East Java). (See Figure 20)

- 9 local hospitals: Bandoeng, Soekaboemi, Garoet, Pasoeroean and Cheribon (Java) and at Medan, Komering Hilir and Palembang (Sumatra) and Makassar (Celebes).

Together these local and provincial hospitals had a bed capacity of 1,498. The largest had a capacity of 214 beds (Garoet). The smallest had only 16 beds (Komering Hilir). The 1929 statistics mention an average occupancy rate of $82 \%$, a total number of nursing days of about 450,000 with a subsidy of approximately $f$ 455,000. The total budget for tegemoetkomingen (subsidies) that year was $f 1.9$ million.

\section{Private Hospitals}

Before 1910, private hospitals had already introduced innovations in hospital care. One of these innovations was the founding of a network of health facilities by missionary organisations (Djokja system). The other major innovation came from the Deaconess hospitals, which put considerable effort into the training of a professional nursing staff. The third group of general hospitals described, was the company hospitals. They earned credits for their role in the improvement of hospital care by organizing patient files and statistics and by making use of analytical and research laboratories.

By 1910, there were 58 private general hospitals and from this year the growth of new hospitals accelerated. The most prominent development was shown by the company hospitals: their growth in number was almost tenfold during this period (See Figure 21). Some companies sponsored hospitals, established and run by missionary societies or by similar charity organizations. The sponsors sometimes financed part of the running costs and supplied the necessary assets such as buildings and equipment.

A total of 26 charity based private main hospitals and auxiliary hospitals were established by both Dutch and foreign Protestant missions before 1910. In addition, a number of four Deaconess Hospitals had been founded. The first was the deaconess Hospital in Batavia. The three other Deaconess Hospitals were founded in Soerabaja (1897), Semarang (1897) and Medan (1900). ${ }^{95}$

95 In order to verify the existence of the 4 hospitals I consulted the Regeeringsalmanak 1930, which mentions the board-members of the Vereeniging voor Ziekenverpleging in NI at Batavia, the Vereeniging "Semarangsche ziekenverpleging", the Vereeniging Soerabaiasche Ziekenverpleging and the Vereeniging tot ziekenverpleging ter Sumatra's Oostkust at Medan. 


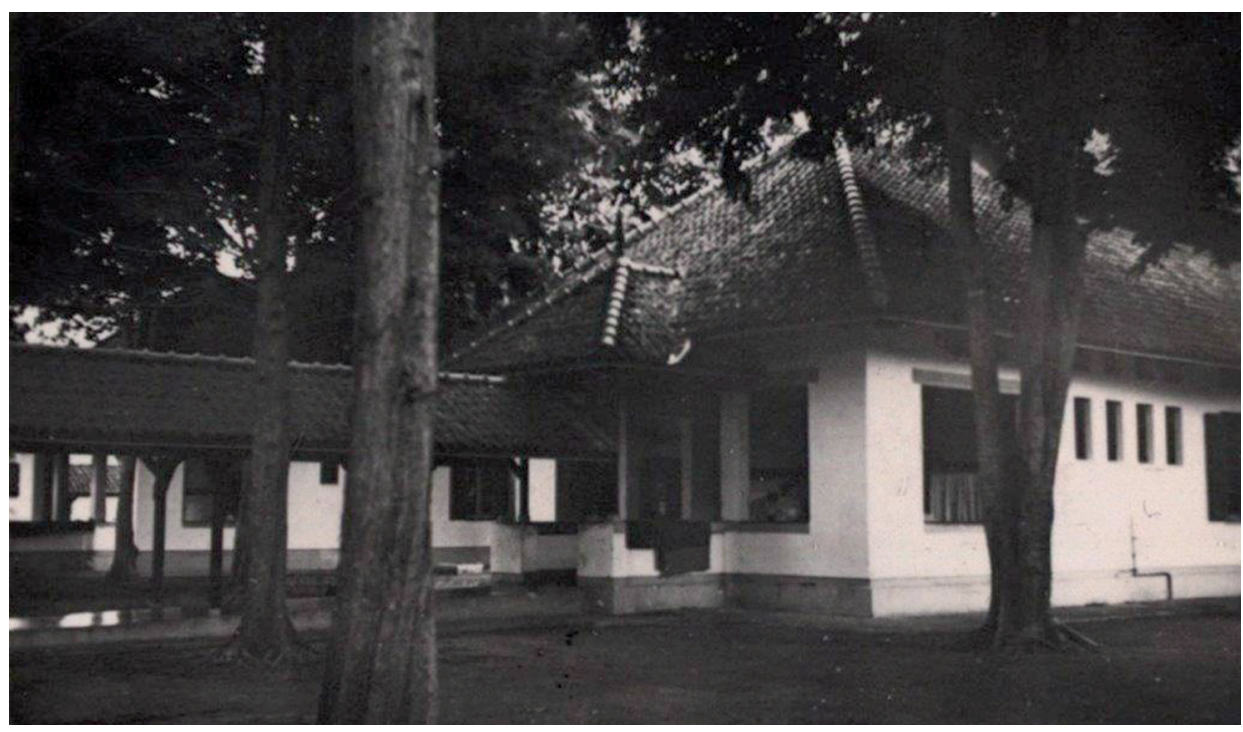

Figure 20 Provincial hospital at Tegal 1930 (KITLV)

\section{Private Company hospitals}

Let us recall the condition of company hospitals as recorded in the period around the turn of the century. On Sumatra about 30 central company hospitals had been founded. By tobacco companies in the East Coast region (22) and by oil and mining companies (8). On Java a few sugar, coffee and tea companies joined forces and established company hospitals for their employees. Additional initiatives were the hospitals founded by mine companies, private or government. Most private company hospitals had been established by mediumsized and large-scale companies or by a joint initiative of a group of small companies. Before 1910 , there were a few government hospitals linked to mine companies. In this category is the government-owned coalmine hospital at Sawahloento (West Coast of Sumatra) and the tin mine hospitals on Bangka. In 1910, a hospital was founded in Benkoelen for the mineworkers in the gold and silvermines at Lebongtandai. In chapter 4 a picture of the well-equipped hospital of Sawahloento was given (see Figure 10). It is not easy to obtain a complete picture of the company hospitals as they were run by diverse companies, ranging from tobacco and sugar and rubber plantations to mining, trading and oil companies.

A total of 301 company hospitals was reported in 1930 (see Figure 21). The largest number of company hospitals was established on Sumatra: 116 hospitals. Combined with Banka (7), Billiton (3) and the Riouw Islands (21) (considered as part of Sumatra), the total group amounts to 147 hospitals. The largest number was found in the plantation belt of Sumatra's Eastcoast. In 1918, E. van de Velde, one of the doctors on a tobacco estate mentioned 33 
central hospitals in this region. ${ }^{96}$ According to another estate doctor, W. Kouwenaar, the maximum was reached in 1930: 47 hospitals with 53 doctors. In later years these numbers decreased because of the crisis. ${ }^{97}$

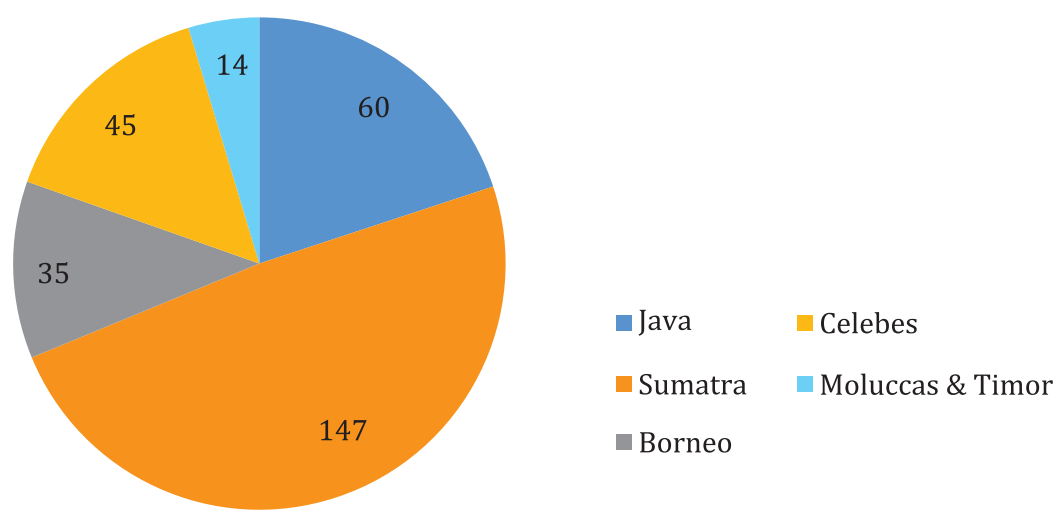

Figure 21 Division company hospitals 1930

It seems incomprehensible that on Java there were only 60 company hospitals, compared to more than 200 in the Outer Provinces. The large number of agrarian companies in the Outer Provinces may be the explanation. Moreover, Java had an advantage in the number of government and subsidized private hospitals, compared to the Outer Provinces. A number of companies on Java outsourced this care to mission and charity organizations. In a comparison between the Deli Plantations and the sugar estates on Java, another reason was noted: the workers in Java experienced a serious disadvantage as they were so numerous that estates did not bother much about their health. ${ }^{98}$ Nevertheless, quite a few hospitals were found on Java that were exploited by sugar and trading companies. About 1920, a report mentioned the existence of outpatient clinics on a number of sugar estates and the establishment of auxiliary hospitals by some companies. Some companies founded their own hospitals or assisted other organizations in subsidizing new hospitals. ${ }^{99}$ Some other hospitals applied for government subsidy. ${ }^{100}$ Before 1920, a number of sugar processing

96 Van de Velde, "Het hospitaal wezen op Sumatra's Oostkust". See legenda with this article (The hospital system on the Eastcoast of Sumatra).

97 Kouwenaar, "De Gezondheidszorg ter Oostkust van Sumatra 1911-1935”, 287 (Health care on the Eastcoast of Sumatra 19111935).

98 W.F. Wertheim, "Conditions in Sugar Estates in Colonial Java. Comparisons with Deli." Journal of Southeast Asian Studies, 24 (1993) 268-284.

99 Van Loghem, Archives of the Sugar Industries in NI (1920).

100 Koloniaal Verslag 1918, Appendix XI. 
entrepreneurs joined forces and founded the Sugar Syndicate of the NI. This programme was intended to motivate other entrepreneurs to join in establishing health facilities. ${ }^{101}$ It will be clear that the way by which companies organized themselves and took care of their personnel was very successful and resulted in almost a 10-fold increase in company hospitals from an initial 32 (1910) to 301 (1930). Therapeutic results were encouraging (decreased mortality) and the local population adopted a more cooperative health attitude. A great deal of this was due to an improved quality of life for patients with yaws, eye-diseases and malaria. The overall balance in this period for the private company hospitals, was a positive one.

In 1920, when J.J. van Loghem, Professor of tropical hygiene and director of that department at the Tropical Institute in Amsterdam, was invited to investigate the hygienic and medical condition of the plantations owned by the Union of Owners of the N.I. Sugar Companies, he reported that many companies exploited or financially supported outpatient clinics. ${ }^{102}$

Some had established auxiliary hospitals, while groups of sugar companies had established their own hospitals or had initiated joint ventures with other organisations to found hospitals. He advised the Sugar Syndicate to follow the example of Deli and join forces to establish central hospitals with well-equipped laboratories. These actions were not motivated by charity but to improve the operational reliability of their companies. ${ }^{103}$

The physician P.W.L. Penris published a thesis on the health care of labourers on agricultural estates on Java in $1930 .{ }^{104}$ The author described the health care developments of the Handels Vereeniging Amsterdam (HVA), a company that exploited the largest sugar factory on Java in an area that previously had not been cultivated or inhabited. ${ }^{105}$ Penris was employed as a company doctor since 1924 and witnessed the building of some 25 'own' kampongs with the necessary annual migration of additional workers from other parts of Java and Madoera. The health condition of these workers was so urgent, that the company decided to establish four outpatient clinics on different locations. Three new factories were started on adjacent concessions. All three acquired an additional outpatient clinic.

101 Abbreviated and translated the motivation was formulated thus: In order to promote the security of the companies by direct and indirect means it may be necessary to proceed into actions with a seemingly pure charity character, which in the end serve the interest of the companies.

102 Ned Tijdschr Geneeskd 112 (1968) nr. 46, 2109: J.J.van Loghem (1878-1968) worked at the Pathological Laboratory of Medan (1908), was leader of the anti-plague team at Malang (1911), director of Tropical Hygiene at the Colonial Institute (1912) and professor of Tropical Hygiene at Amsterdam (1916) and Wageningen (1923).

103 J.J. van Loghem, "Denkbare samenwerking van suikerondernemingen op hygiënisch en geneeskundig gebied” Transl.: "Possible cooperation of sugar mills in the field of hygiene and medicine "Archief voor de Suikerindustrie in Nederlandsch Indië, March 1920.

104 P.W.L. Penris, De geneeskundige verzorging van arbeiders bij landbouwkundige ondernemingen op Java. Transl.: The medical care of labourers with Agricultural Enterprises on Java (Amsterdam 1930).

105 HVA: Handels Vereeniging Amsterdam (Commercial Association Amsterdam), a conglomerate of commercial, industrial and plantation companies. 
By the end of 1929 the entire sugar industry, affiliated with the Sugar Syndicate, was involved in direct health care (see Figure 22).

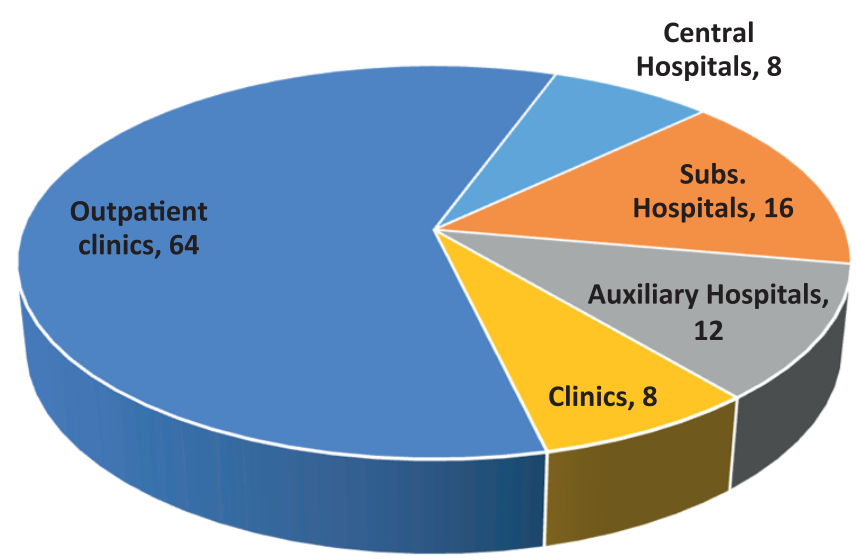

Figure 22 Health facilities in the Sugar Industry on Java in 1929 (Source: Ned Tijdschr Geneeskd 1948.)

The example of a sugar company that developed new concessions may illustrate how health care facilities were gradually established.

At first we had to await the reaction of the population in offering Western health care. By inviting a number of framboesia (yaws) patients and treating them with salvarsan, we booked such a success, that we soon could open a second polyclinic (May 1925) and a third one (July 1926), followed by a fourth at the beginning of 1928. Mantri-nurses were daily present in each outpatient clinic. If they could spare some time, they went out to make contact with the desa population, trying to persuade them to go to the polyclinic or the hospital for necessary medical interventions. All consults and hospital admissions were for free. Soon it became clear that our medical assistance was needed. In 1924, at the beginning of my service a number of 5,000 consults were booked at the hospital outpatient department. In 1928 the number had increased to 17,000, while in the other 6 outpatient clinics (2 additional ones had been opened in 1928) another 59,000 consults were realized. In that year we recorded 16,000 new patients. At first we treated mainly patients from the "own" kampongs, but in 1928 we serviced an area as large as the province of Utrecht. In 1929 we opened a new hospital with 168 beds (160 for indigenous patients and 8 for Europeans). The company took care of the exploitation, without receiving subsidies. ${ }^{\text {'06 }}$

106 P. Penris, "Het aandeel der landbouwondernemingen op Java in de geneeskundige voorzieningen van NI," Transl.: “The participation of agricultural firms in medical care in NI” Ned Tijdschr Geneeskd 92 (1948) 1438-1445. 
This brings us back to the motives for founding company hospitals: they were not erected for charity reasons, but for the benefit of the companies, let us say for cost reduction reasons. This is also illustrated by a report on the hospital Petoemboekan of the Serdang Doctor Fund, in which a rather blunt calculation is made: The total amount saved during the period 1906 until 1925 was calculated at approximately $f$ 880,000, due to a diminished death-rateloss of coolies (one saved life of a coolie being estimated at $f 100$ ). ${ }^{107}$

\section{Private charity hospitals}

Missionary hospitals took the lead on health care initiatives based on charity. They were accompanied by a few Deaconess Hospitals. These first two groups consolidated their position and especially the Roman-catholic missions were successful and expanded after 1920. After 1910, some new groups joined the pioneers of charity-based hospitals: it was the Salvation Army and hospitals founded by other associations, such as the Moehammadyah.

\section{DEACONESS HOSPITALS}

The Emma Hospital (or Tjikini Hospital) established in 1896 at Batavia received an annual subsidy varying from $f 5,800$ (1911) to $f 13,635$ (1929). ${ }^{108}$ The hospital maintained an outpatient department for the poor (on-en minvermogenden) and had a small capacity for poor inpatients, varying from class I (10-25 beds) in 1911 to class II (26-75 beds) from 1921. In the KV reports it can be deduced that the hospital only received subsidy for the departments that gave free services to the poor. As the paying patients formed a group that was three times larger, the real capacity of the Batavia Deaconess Hospital may have been three times as large as is suggested by the number of subsidized beds. The hospital had a well-trained nursing staff of 9 European deaconesses (1911) and organized training facilities for indigenous nurses. Up to 1912, the statistics of this hospital were annually reported in the Koloniale Verslagen.

In the Memorial Book of 40 years' history of the Tjikini or Queen Emma Hospital, it appears that in 1930 the number of occupied beds was on average 92 (33,569 nursing days). Only about $10 \%$ of this capacity was used by Min- en onvermogenden. First and Second Class patients occupied the remaining $90 \%$ capacity. In 1930 the number of European nurses was 29 and student nurses 49 (30 European and 19 indigenous). At the same time, the hospital had 5 medical specialists on a more or less regular base. They took care of Surgery, ENT, Ophthalmology, Gynaecology, Paediatrics and Dermatology. ${ }^{109}$

\footnotetext{
107 G. Baermann, Report 1919-1925 Serdang Doctor Fonds (Medan s.a.).

108 Koloniaal Verslag 1912, Annex O, Table XI and Indisch Verslag 1930, Annex O, Table XI.

109 Gedenkboek 40 jaar ziekenverpleging, Koningin Emma Ziekenhuis (“Tjikini”), Vereeniging voor ziekenverpleging in Ned. Indië 1895-1935 (Batavia s.a.) Transl.: Memorial-book of 40 years nursing by the Queen Emma Hospital (“Tjikini”), Association for Nursing in the NI 1895-1935.
} 
In Chapter 4 the entire picture of Deaconess hospitals in the NI was explained. Beside the Tjikini hospital, three other Deaconess hospitals had been established at about the same time. They were founded between 1897 (Soerabaja and Semarang) and 1900 (Medan).

\section{ROMAN-CATHOLIC AND PROTESTANT MISSIONARY HOSPITALS}

In 1926, the missionary doctor J. Cohen arrived at the St. Elisabeth Hospital at Lela on Flores. He was the first Dutch doctor who joined the Roman Catholic mission in the Netherlands Indies. Before his arrival the R.C. missionary hospitals had a disadvantage compared to Protestant hospitals. ${ }^{110}$ Given the lack of missionary doctors their status had been that of an auxiliary hospital (hulpziekenhuis). This was the reason why they received a small subsidy.

The St. Elisabeth Hospital did not even figure in the list of subsidiaries. ${ }^{111}$ Four years later, the list of the Public Health Service counted six R.C. missionary hospitals, which together received about $f 60,000$. The congregations of Franciscan nuns were the most active and founded hospitals in the Western part of Borneo. St Elizabeth at Sambas was founded by the Franciscan nuns of Etten. The Servants of the Holy Spirit at Steyl founded a hospital at Soerabaja in 1925, the St. Vincentius hospital. The well-known hospital 'Onder de Bogen' at Jogjakarta was inaugurated on $24^{\text {th }}$ August 1929 by mgr. A.P.F. van Velsen and was designed by the architect F.J.L. Ghijsels (see Figure 23). It was founded by a Maastricht congregation: The Sisters of Carolus Borromeus, also known as Sisters 'Onder de Bogen.'

In Chapter 4, it was noted that during the period 1890-1910, 26 main hospitals and auxiliary hospitals had been established

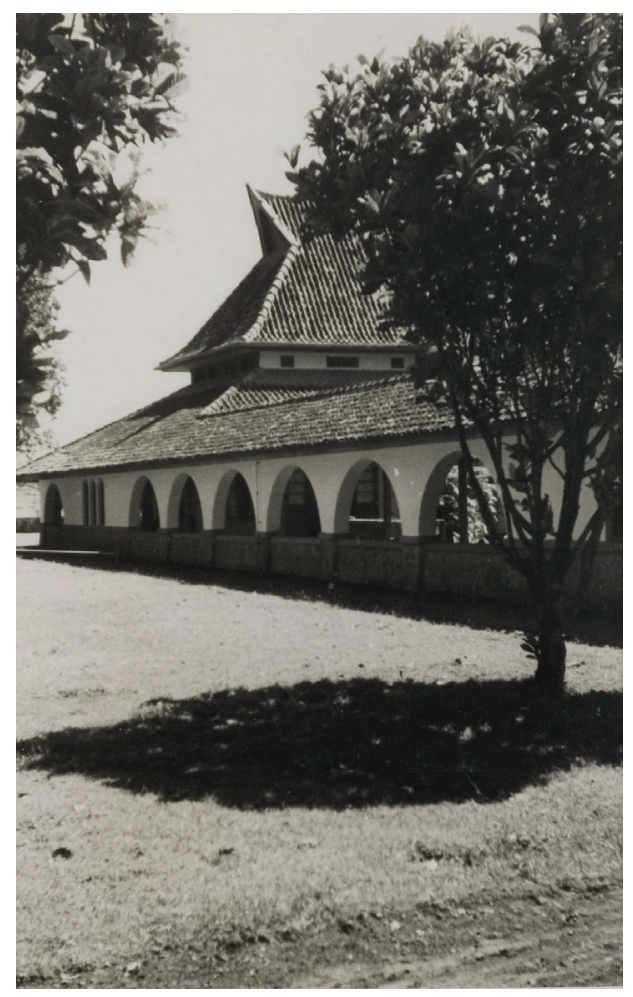

Figure 23 Hospital ‘Onder de Bogen’ 1930 (Source KITLV)

110 J. Willemsen, Van tentoonstelling tot wereldorganisatie, de geschiedenis van de stichtingen Memisa en Medicus Mundi Nederland, 1925-1995.Transl.: From exhibition to World organization, the history of 2 Roman-Catholic medical mission foundations (Nijmegen 1996) 93-100.

111 Indisch Verslag 1930, Annex O, Table XI, Overzicht van de in 1929 toegekende tegemoetkomingen ten behoeve van particuliere Inlandsche (hulp) ziekenhuizen (Survey of 1929 subsidies to private hospitals and auxiliary hospitals). 
by Dutch and foreign Protestant missions. During the next 20 years this number increased and new Roman Catholic missionary hospitals joined the ranks. By 1930, the number of missionary hospitals had increased to 57 (including auxiliary hospitals). The subsidies that the missionary hospitals received in that year was approximately $f 900,000$. The 34 auxiliary hospitals received $14 \%$ of this amount $(f 120,000)$. The main hospitals received almost $f 34,000$ on average per year. The protestant missionary societies had 38 hospitals. The Roman-Catholic missionary congregations in the NI reported the existence of 19 hospitals and four other health facilities. Six of these hospitals were established on Java, 13 in the Outer Provinces. They were distributed as follows: on the Moluccas and Kai islands (2), Sumatra and Riau Islands (4), Borneo (5) and Celebes (2). ${ }^{112}$ The 1930 Indisch Verslag reported some basic data on 12 of the more important missionary hospitals (see Table 12). Selection criteria were not mentioned. These hospitals had more than the average capacity ( $>100$ beds) and enjoyed a minimum annual subsidy of $f 25,000$.

Table 12 Statistics of some well-known missionary hospitals 1930

\begin{tabular}{lcccc}
\hline Hospital & $\begin{array}{l}\text { Bed } \\
\text { capacity }\end{array}$ & $\begin{array}{l}\text { Avg number } \\
\text { of patients }\end{array}$ & Nursing Days & Subsidy $(\boldsymbol{f})$ \\
\hline Blora & 95 & 141 & 51331 & 38841 \\
Jogjakarta & 380 & 355 & 129862 & 107506 \\
Soerakarta (Zending) & 208 & 253 & 94772 & 72952 \\
Soerakarta (Ziekenzorg) & 156 & 143 & 51926 & 43320 \\
Poerbolinggo & 109 & 130 & 47419 & 33626 \\
Poerworedjo & 156 & 160 & 58490 & 43076 \\
Keboemen & 159 & 186 & 67281 & 45494 \\
Kelet & 119 & 105 & 38174 & 25147 \\
Modjowarno & 176 & 213 & 105853 & 64577 \\
Tjepoe & 124 & 120 & 43630 & 29575 \\
Balige & 75 & 142 & 51762 & 32156 \\
Pearadja & 51 & 101 & 37667 & 27236 \\
\hline
\end{tabular}

Source: Indisch Verslag 1930

These hospitals were apparently very popular, for the occupied capacity of the 12 hospitals together exceeded the available capacity (by more than 200 beds). This suggests that the public highly favoured these hospitals. In this particular case, demand exceeded supply. This was not coincidental, for even after increase of capacity, the bed occupancy rate of these hospitals kept rising in the succeeding years.

112 J. Willemsen, Van tentoonstelling tot wereldorganisatie, 3.8 Missieziekenhuizen en missieartsen, 1918-1939. Transl.: From exhibition to world organization, 3.8 Mission hospitals and mission doctors, 1918-1939. 


\section{THE SALVATION ARMY}

One of the reporters from the Nieuws van den Dag sang the praise of the institute for zieke en behoeftige inlanders (poor and sick indigenous persons) Boegangan at Semarang: "Very beautiful and instructive was the lantern-lecture on Boegangan. It was evident, looking at these pictures, what a blessing the work of the Salvation Army represented. Not few Javanese who now plough their sawah would have been dead and gone, had not there been Boegangan with its friendly medical director and its self-sacrificing nurses." The officer in charge at that moment was B. Meijer, captain in the Salvation Army.

The Salvation Army had been founded in Great Britain in 1887 and from 1894 it was present in the Netherland Indies. The organization emphasized social work in the cities of the Netherlands Indies and was established in Peloran on Central Java in 1905. The headquarters moved to Semarang (1905) and to Bandoeng (1917). In 1910, the Salvation Army Officer van Emmerik was given permission by the NI Government to start a colony on Celebes (Palutal). ${ }^{113}$

In this same year, the Salvation Army started the first health care projects in the NI. In the next 20 years, the Salvation Army was charged with the management of nine hospitals, only two of which were general hospitals. The two general hospitals were the Boegangan hospital at Semarang (1910) and a small auxiliary hospital at Toeren near Malang (1919). The subsidy survey in 1914 mentions the Boegangan institute as a $3^{\text {rd }}$ class hospital (75-120 beds). The hospital at Toeren was a category II hospital (26-75 beds) that later was replaced by one of 100 beds. ${ }^{114}$ The seven specialized hospitals managed by the Salvation Army were leprosy facilities, an eye clinic and a mother and child clinic. These specialized hospitals were:

- Pelantoengan hospital in the Residency Semarang, founded by the military in 1875 . In 1910, its operational management was entrusted to the Salvation Army. ${ }^{115}$

- The Semaroong foundation at Soerabaja that in 1911 had been changed into the government "Leprozengesticht Semaroong" and at the same time had been contracted out to the Salvation Army. ${ }^{116}$

- In 1914, some plantation companies at Sumatra's East Coast founded a leprosy institution at Belawan (Poelau Si Tjanang) and, from the start, the Salvation Army took responsibility for its management. ${ }^{117}$

- The same happened with a leprosy institution on Bali at Panijer Daoe. In 1918, The Resident of Bali and Lombok arranged with the direction of the Salvation Army to have the place managed. ${ }^{118}$

\footnotetext{
113 Salvation Army, Territory Dutch East Indies, Repertorium van Nederlandse zendings-en missiearchieven $1800-1960$.

114 Het Ned Tijdschr Geneeskd reports on 10 September 1932 the opening of the renewed clinic that could house 100 patients (Ned Tijdschr Geneeskd. 76. III.37. 4377).

115 The Supplement NI Statutebook 1904, no. 6004 regulates the agreement with the Salvation Army.

116 Staatsblad van Nederlandsch-Indië 1911, no. 585 (NI Statutebook 1911, no. 585).

117 Kouwenaar, Gezondheidszorg SOK 1911-1935, 292.

118 Governmental Decree no. 30 of 21th October 1918.
} 
- In 1918, a leprosy colony was founded at Koendoer (Palembang) as well. ${ }^{119}$

- At Soerabaja a Mother and Child clinic was opened in 1917. The hospital was recorded as a category II hospital and was subsidized. This hospital was named after the founder of the Army: William Booth Hospital. ${ }^{120}$

- In 1920, the Salvation Army founded an Eye hospital at Semarang: The General William Booth Eye Hospital. ${ }^{121}$

\section{OTHER CHARITY HOSPITALS}

Apart from the 63 general hospitals that were run by missionary (57) and deaconess organisations (4) and the Salvation Army (2), an additional 26 hospitals were founded by other non-profit organisations. ${ }^{122}$ Of the remaining hospitals, the following organizations took care (See Figure 24). ${ }^{123}$ The total bed capacity of all the subsidized private hospitals and auxiliary hospitals together was 5,714 beds in $1929 .{ }^{124}$

\section{Specialized hospitals 1910-1930}

The composition of the category of specialized hospitals changed in the course of time. Those changes could be very abrupt due to developments in medical research or changing medical policies. Hospitals that were badly needed previously, such as the institutions that cared for beriberi patients, were assigned other functions or were simply closed.

This happened to the vast category of hospitals for syphilis, which closed due to a drastic change in medical policies. This occurred in 1911, when the Civil Medical Service executed the recommendations of the Reorganization Commission of 1906 relating to the inspection and care of patients with syphilis. The Commission based its conclusion on the fact that there was no evidence that the financial means used for the inspection and the compulsory hospitalization of prostitutes had achieved a positive effect. Internationally this kind of regulations had already been condemned in 1877, when the Congress held at Geneva pronounced: "La Section d'Hygiène constate le complet insuccès de tous les systèmes de police des moeurs ayant pour but de réglementer la prostitution..." ${ }^{25}$ In 1908, France abolished its legal regulations concerning prostitution and the NI Government followed these international developments by abolishing the medical examinations of prostitutes by physicians from 1 March 1911. Consequently, from that date all the hospitals for women with syphilis were closed. ${ }^{126}$

119 The Newspaper, Nieuwe Rotterdamsche Courant of Thursday 5 april 1928 reports on "Mooi heilslegerwerk onder de leprozen." Transl.: Nice work of the Salvation Army amid leprosy patients.

120 Koloniaal Verslag 1918, Annex Q.

121 Salvation Army, Territory Dutch East Indies, Repertorium van Nederlandse zendings- en missiearchieven 1800-1960.

122 Koloniaal Verslag 1929, Annex P, Numerieke Opgaven betreffende den Dienst der Volksgezondheid in Nederlands-Indië, merendeels over de Jaren $1924 \mathrm{t} / \mathrm{m}$ 1928. Tabel I. Transl.: Statistical report of the PHS in NI from 1924-1928.

123 Regeeringsalmanak 1930, Kalender en Personalia, Ziekenverpleging, 536-546.

124 Indisch verslag 1930, De Sociale Toestand, Gezondheidszorg, 384.

125 The Hygiene Section of this Congress establishes the complete lack of success of all the systems applied to regulate prostitution. 126 Bijblad Staatsblad van Nederlandsch-Indië 1910, no. 7332 (Supplement NI Statutebook 1910, no. 7332). 
New hospitals were created to meet the needs of patients suffering from diseases that were hardly known formerly. After 1910, the NI government supported, in particular, new private initiatives devoted to the care of patients suffering from tuberculosis and opium addiction. The NI government accorded allowances to convalescence centres for sick and feeble children and decided to support the experimental care of mentally deranged persons by the missionary association at Temanggoeng (Central Java). It is hardly possible to discuss all the initiatives that were taken in this period. The following paragraphs will deal with the initiatives in the fields of leprosy, tuberculosis, eye diseases and psychiatry.

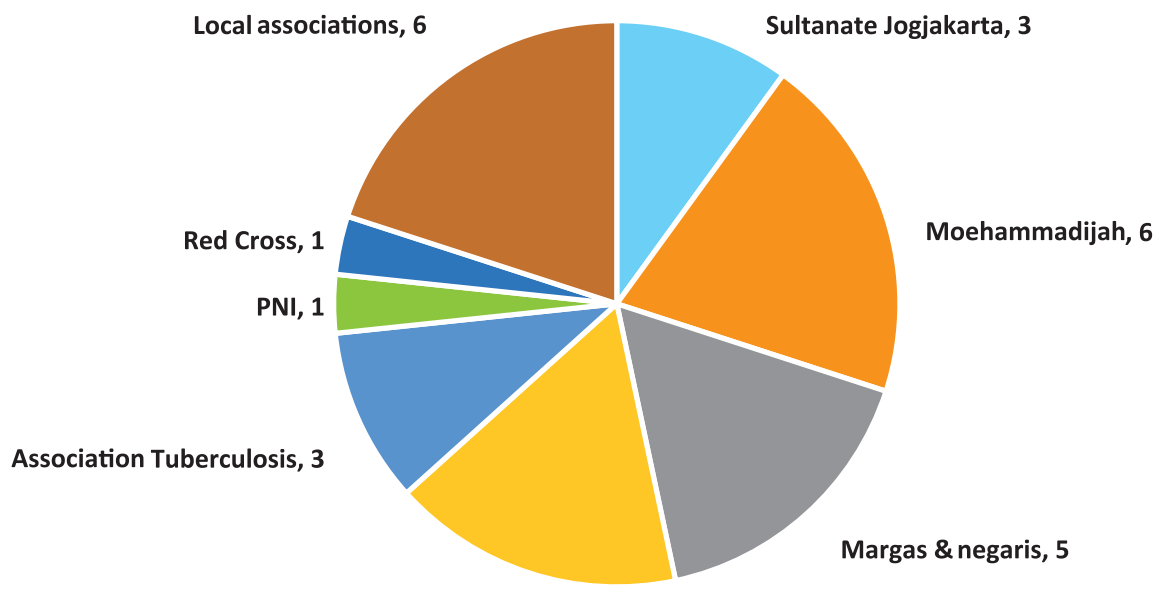

Association Leprosy, 5

Figure 24 Charity facilities managed by other organizations

\section{Leprosy institutions}

In Chapters 3 and 4, the government policy with regard to leprosy has been discussed. The Vereeniging tot bestrijding van lepra (Association to combat leprosy) was founded in 1908. In 1911, the Vereeniging Het Oranje Kruis, Nationale Bond ter bestrijding der Melaatschheid (Lepra) in NI had been founded, a national league to combat "melaatschheid" (leprosy) in the Netherlands Indies. In 1920, W.Th. de Vogel, Chief of the Civil Medical Service and H.M. Neeb, colonel of the MGD presided over its board. ${ }^{127}$ Similar associations were formed in specific regions, e.g. Moluccas. In 1910, six leprosy institutions existed on Java, while the number had expanded to 14 on the Outer Islands. From 1910 to 1930, many of the missionary societies had compassion for leprosy patients and founded quite spacious 
facilities, in which their patients were supposed to live an almost normal village life (see Figure 25). In 1929, the Koloniaal Verslag mentions 46 facilities: two governmental hospitals, 18 subsidized private and 26 non-subsidized leprosy institutions; 42 of these institutions were in the Outer provinces and four on Java, one of which was the former military one at Pelantoengan (Central Java), taken over by the Salvation Army in $1908 .{ }^{128}$ The latter organization was charged with the management of 4 other leprosy asylums: one on Java, one on Bali and two on Sumatra.

Unfortunately, the policy of the NI Government did not make a provision for the obligatory registration of all leprosy cases and therefore over successive years the statistics on leprosy were accompanied with the remark: the statements deserve no confidence.

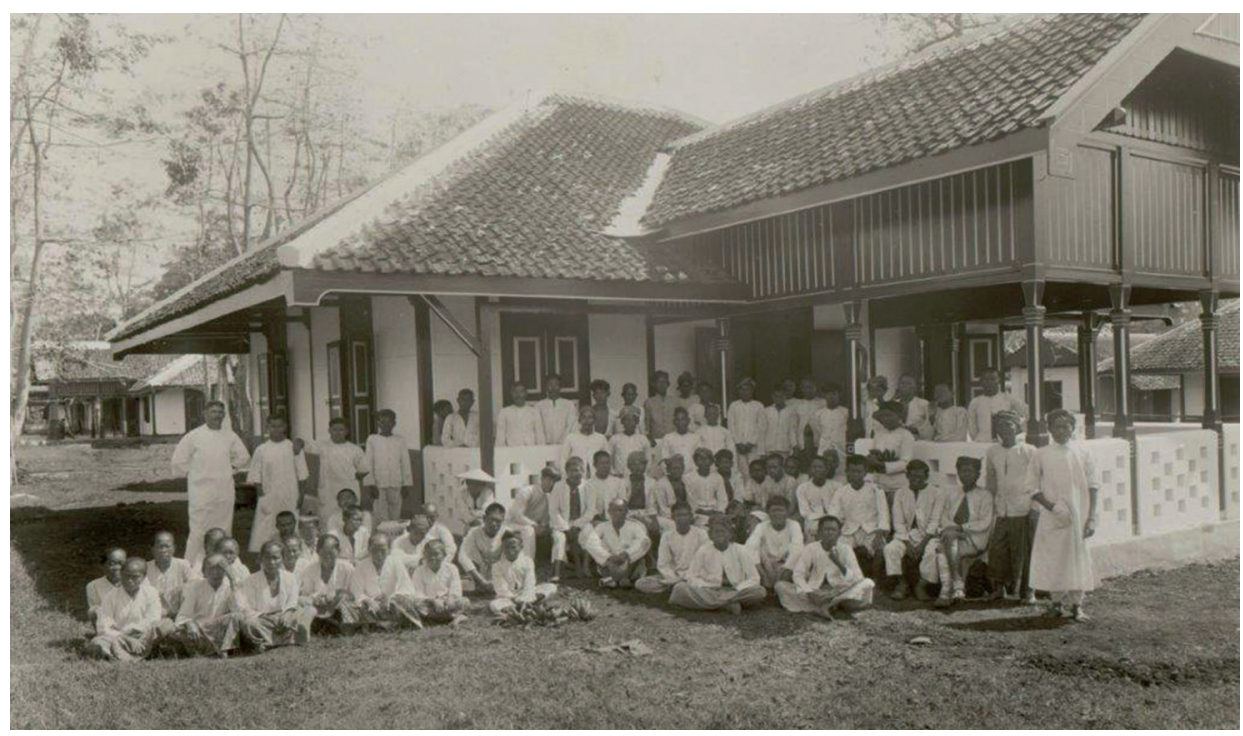

Figure 25 Leprosy village at Kelet, 1920 (Source: KITLV)

The Islands of the Moluccas had known a concentration of cases of leprosy for a long time, reaching back to VOC-times and before. Leaving his office in 1928, Governor van Sandick of the Moluccas looked back and described the hesitating way, in which for many years, leprosy had been treated and the problems that arose when the new policy of voluntary isolation was introduced. ${ }^{129}$

$128 K V$ 1930, Annex O, Table I.

129 Bestuursmemorie van gouverneur L.H.W. van Sandick in 1926 voor zijn opvolger J. Tideman (Memorandum of transfer of office of governor van Sandick to his successor). 
As his account reveals some of the religious and political intrigues around hospital initiatives, it is told in his own words (abridged and translated): 'The old plague barracks in the vicinity of the military hospital had never been used for its purpose. They were restored in order to allow a dozen leprosy patients to live there.' Van Sandick continues and explains the attitude of Ambon families towards leprosy patients among their own family members:

As long as leprosy patients stay within their family, care is taken for their livelihood, although it may be rather primitive and poor. However, as soon as the leprosy patient leaves the compound, the Ambon family will seldom be prepared to continue supporting him, nor will the community.

The financial burden grew as the number of patients increased. Moreover, the barracks had to be cleared and new premises bought. Initially there was no subsidy available, but from 1919, the Association at Batavia received subsidy for the establishment of a leprosy hospital. However, how to manage an institution by an association, established at a distance as far as Batavia? The resident of Ambon made suggestions to the chief of the Civil Medical Service to entrust the management to the Salvation Army. After many alternative proposals had passed, the Governmental Decision of 24 August 1920 assigned the management to the Christian Protestant Association that in the meantime had been established by the Protestant minister. Nevertheless, many objections to this choice remained.

In 1922, the newly appointed Resident (the same van Sandick) interfered and a decision was taken to found a new association, the 'Association to combat Leprosy in the Moluccas' and to entrust the management of the Leprosy Hospital to this Association. ${ }^{130}$ By 1925 the number of inpatients had increased to 150 and it was decided to move to other, larger premises as the prognosis for the future indicated the need for a capacity of 500 places. This capacity would be necessary, if and when the intended compulsory isolation would be effectuated. There was considerable pressure from medical side to introduce enforced isolation, because the Moluccas were considered a focus of infection, ranking above all other regions of the NI.

\section{Sanatoria for tuberculosis}

In 1882, Robert Koch (1843-1910) had given his lecture about the discovery of the tuberculosis bacterium, but the struggle between contagonists and miasmatics still continued, and in The Netherlands too, Koch met fervent opponents of his bacteriological

130 The Governmental Decision of 22 September 1922 no. 30 approved the statutes of the Vereeniging tot bestrijding der lepra in de Molukken. The Moluccas was at that time a Residency, not a Government and van Sandick was the Resident. 
theory. ${ }^{131}$ Despite these fierce scientific disputes, the general opinion at the end of the $19^{\text {th }}$ century was that tuberculosis was an important epidemic disease. This opinion was based on mortality statistics that had been kept following a new classification, approved by the Netherlands Medical Association (NMG). The causes of death were regularly published in the Nederlands Tijdschrift voor Geneeskunde. ${ }^{132}$ From 1900 to 1910, this Journal opened its columns for discussions on all aspects of tuberculosis.

Since in this decade almost 10,000 patients per year died of tuberculosis in the Netherlands, many local and private initiatives were started to treat patients and to combat the disease. In 1903, the first TB prevention clinic was opened at Rotterdam by a local association of physicians, soon to be followed by similar initiatives in other Dutch cities. On September 1903, two sanatoria (Hellendoorn and Hoog-Laren) together with the Rotterdam association founded the Netherlands Central Committee, that in 1907 continued its mission under patronage of Queen Emma but with a new name: Netherlands Central Association to combat tuberculosis. The objectives of the new Association were to promote co-operation between associations, foundations and individuals in the field of cure, care, research and fundraising. Right from the beginning, a debate took place between the curative (sanatoria) and the control (the local associations) side. From 1918, because of the divergent opinions in the field and the strong increase of morbidity and mortality during WW I, the Dutch Government became involved. A parliamentary discussion led to the inauguration of the State Commission Heynsius van den Berg and to a commitment by the government in regulating, controlling and financing preventive actions by local and district prevention teams and clinics. ${ }^{133}$

In the Netherlands Indies, the Central Association against Tuberculosis was founded in 1918 , but it already had started its work in 1916, when some tuberculosis patients were nursed on account of the Association at the convalescence centre Sindanglaija, not far from Patjet. The Association received support from its counterpart in the Netherlands, the Netherlands Central Association to combat Tuberculosis.

Before the $20^{\text {th }}$ century in some circles, the idea prevailed that in a country with so much sunshine and people living outdoors, tuberculosis could not play an important role. Experiences taught otherwise and during the $19^{\text {th }}$ century tering (consumption) could be encountered in the monthly statistics of the Military Medical Service. Peverelli mentions that the number of tuberculosis patients, admitted in Governmental Civil Hospitals, amounted to some $3.5 \%$ of all admittances, in 1928. This was why the Central Association

131 M. van Daal and A. de Knecht-van Eekelen, "Over aetiologie en therapie van tuberculose: het debat in Nederland (19001910)", Gewina 15 (1992) 211-233. Transl.: About etiology and therapy: the debate in the Netherlands.

132 Houwaart, De Hygiënisten, Artsen, staat en volksgezondheid, 173-175.

133 J.V. Kuyvenhoven and J.F. Broekmans, "Honderd jaar Koninklijke Nederlandse Centrale Vereniging tot bestrijding der Tuberculose (KNCV)”, Ned Tijdschr Geneeskd 147 (2003) 1869-74. Transl.: Centennial Royal Dutch Central Association to combat Tuberculosis. 
against Tuberculosis was established. The Association aimed at opening sanatoria and TB prevention clinics to assist the population in fighting this disease. ${ }^{134}$ The NI government financed its activities and provided subsidies for the sanatoriums that the Association established. The subsidies granted $75 \%$ of the investment costs and a similar percentage for budgetary deficits.

In the evening edition of the Bataviaasch Nieuwsblad of 8 September 1919, a news item could be found on the opening of a sanatorium in the mountains near Batavia. The opening ceremony involved the unveiling of the commemorative plaque, stating "Eerste sanatorium voor longlijders in Nederlandsch Oost-Indië, Patjet, geopend op 6 September 1919 door de Beschermvrouwe der Centrale Vereeniging tot bestrijding der tuberculose, N. gravin van Limburg Stirum, geb. Sminia." ${ }^{135}$ In her opening speech Mrs. Van Limburg Stirum, the wife of the Governor-General, reminded her audience that the Central Association had been made possible by gifts from high ranking persons like the Queen-mother, Emma, by support from the Netherlands Central Association and of many members, present at this ceremony. Among them were medical officials as chief inspector, W.Th. de Vogel, the viceprincipal of the STOVIA, C. D. de Langen and the vice-president of the Raad van Nederlandsch Indië, H.N.A. Swart (see Figure 26). The new sanatorium had a nurses' home, flanked by two pavilions and annexes. The lighal (garden-shelter) was situated towards the rear end of the terrain on a more elevated place, with a view on the Gunung Gede.

Prior to 1930, the Association opened another three sanatoria on Java at Garoet (West Java), Pasoeroean and Soerabaja (both East Java). In the 1920s, two sanatoria were established on Sumatra: one sanatorium was a converted convalescence center at Bandar Baroe (Sumatra) of the Amsterdam-Deli Company. The other was established by the Senembah Company at Brastagi in 1922. Kouwenaar reports on a separate association at Medan that opened a tuberculosis outpatient clinic in that town, which attracted many patients. This association was financed by contributions of its members and by the so-called Maandagcent: each pupil at school gave 1 cent a week for this purpose. In this way participation of the community provided an annual contribution of about $f 6,000 .{ }^{136}$

\section{Eye hospitals}

It was mentioned in the previous Chapter that a lot of children in the archipelago were victims of trachoma, a chronic inflammation leading to blindness if not treated. Therefore, initiatives that fought eye diseases were mentioned. The northern part of Java, the Moluccas and Atjeh were the regions that were strongly affected.

134 P. Peverelli, De zorg voor de Volksgezondheid in Nederlandsch-Indië ('s Gravenhage, s.a..) 80-84.

135 Opening of the first Tuberculosis Sanatorium at Patjet (West Java) by the patroness of the Central Association against Tuberculosis.

136 Kouwenaar, W., “De gezondheidszorg ter Oostkust van Sumatra 1911-1935”, GTNI 76 (1936) 292-293. 


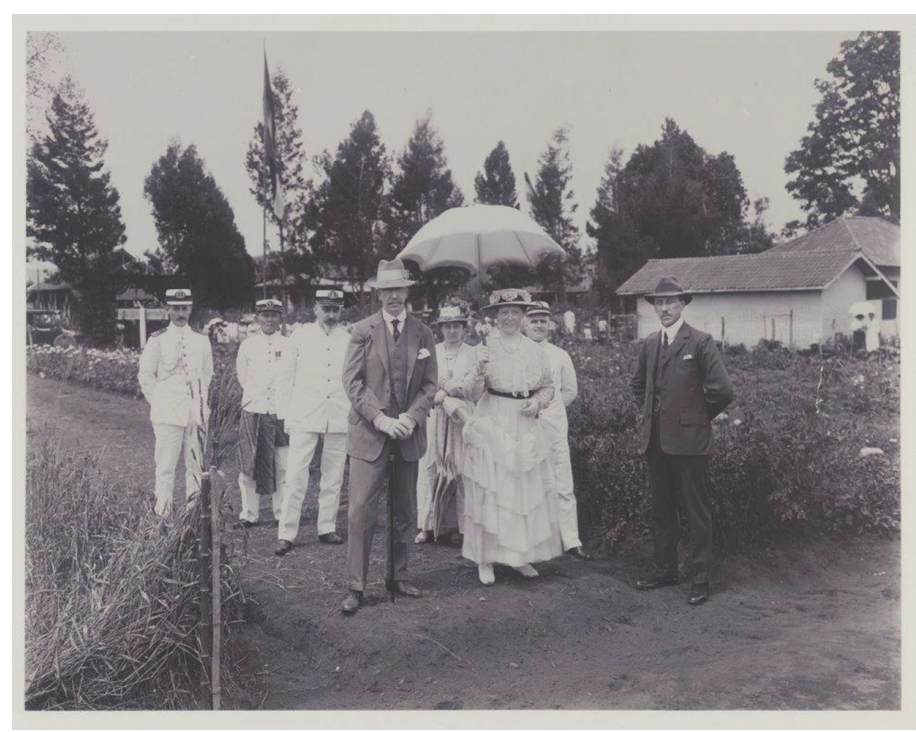

Figure 26 Opening Sanatorium Patjet near Tjiandjoer, 1919 (Source: KITLV)

Before 1910, four eye clinics had opened their doors on Java, at Bandoeng, Ngawi, Semarang and at Kertosono. The Association to improve life conditions of blind people in the Netherlands Indies went on to promote the establishment of outpatient clinics. In 1913, the Queen Wilhelmina Eye Hospital at Bandoeng lost its dedicated director C.H.A. Westhoff (1848-1913). It was the year in which the hospital celebrated its first lustrum and reported its achievements. ${ }^{137}$ The director was succeeded by the ophthalmologist G.P. Utermöhlen, but a few years later P. Wijn is mentioned to be the director, the former health officer, who had started an eye clinic at Ngawi.

Beside the four eye clinics of the initial period, new hospitals were built in later years. Two were private initiatives: A private association started a clinic at Soerabaja in 1917 and the Chinese doctor Yap established an eye clinic at Djokjakarta in 1928. The Public Health Service opened centres with an ophthalmologist and a specialized nurse for the regions of Bantam, Cheribon and North Soerabaja, regions with a prevalence of trachoma of 20 to $25 \%$. Local authorities founded a clinic at Pemalang (Central Java). One of the very successful initiatives was the Eye Clinic of Moehammadyah at Soerakarta which in the first year after opening (1929) treated almost 18,000 patients for free. This organization also started an

137 In this year, 4,283 new patients were treated and 962 admissions (27,948 nursing days) took place. The bed occupancy was on average 77 beds and the average length of stay 29 days. 
ophthalmic polyclinic at Batavia, downtown which treated some 60 patients per day. ${ }^{138}$ By 1930, the number of eye clinics had increased by four. All eight eye hospitals could be found on Java.

\section{Psychiatric hospitals}

Halfway the $19^{\text {th }}$ century the necessary psychiatric hospital capacity for Java had been estimated at 500 patients. In 1902, the available capacity (Buitenzorg hospital) increased by 900 beds, when the new hospital at Lawang (East Java) opened (See Figure 27). In 1910, the number of available hospital beds was nearly 2000 beds. By 1930, about 7,000 hospital beds were available. Another psychiatric hospital was established at Magelang (Central Java) in 1925. This hospital had about 1300 beds and surpassed the Buitenzorg hospital in building costs: $f 2$ million against $f 1$ million. This building budget of $f 1,400$ per bed aroused indignation and the comment that in the NI a tendency to perfectionism rather provided an excellent accommodation for the few than having acceptable shelters for the many. ${ }^{139}$ Some years later at Sabang, the fourth psychiatric hospital arose with 1,222 beds. The records do not mention its building budget, but a considerable amount of money was spent on this kind of facilities, while experience taught that building hospitals and arranging for more beds did not solve the problem of an ever increasing need of care for psychiatric patients. The annual discharge percentage of patients was about $6 \%$, so there could be admitted every year only 420 new patients, while the real demand was tenfold that.

To solve this discrepancy new types of mental institutions were founded, such as Doorgangshuizen (Temporary Refuges) for the treatment of acute cases for up to six months and Verplegingshuizen voor krankzinnigen (Nursing Homes) for long-stay patients. ${ }^{140}$ Besides, the problem of long term care was partially met by the founding of so-called Landbouwkolonies (Agricultural communities). ${ }^{141}$ The long term patients who did not need intensive nursing, could live and work together and become part of the surrounding community. ${ }^{142}$ Sometimes quiet patients found work in the hospital or were placed by families in the neighbourhood. An example of these Landbouwkolonies was the experimental one at Lenteng Agoeng that was set up near the Buitenzorg Hospital for 200 ex-patients. ${ }^{143}$ The Salvation Army started $a$

\footnotetext{
138 Indisch Verslag 1930 bijlage A, Verzorging van geestelijke behoeften en sociale welvaartszorg uit inlandschen kring, 36-70. Transl.: Care for immaterial and social needs by indigenous organizations.

139 Indisch Verslag 1930 bijlage A, 33.

140 Staatsblad van Nederlandsch-Indië 1922, no 110 (NI Statutebook 1922, no. 110) mentions the usual staff, consisting of one nurse 1st class, two mantri-nurses and eight attendants.

141 Ch.W.F. Winckel, "De Dienst der Volksgezondheid in Nederlands-Indië", Ned Tijds v Gkd 92 (1948) 1206- 1216. The first private subsidized colony at Lenteng-agoeng near Batavia was founded in 1934. It was an initiative of the psychiatrist, Van Wulften Palthe.

142 H. Pols, "The development of psychiatry in Indonesia: From colonial to modern times". International Review of Psychiatry. 18 (2006) 363-370.

143 Peverelli, Zorg voor de Volksgezondheid, 33-35.
} 


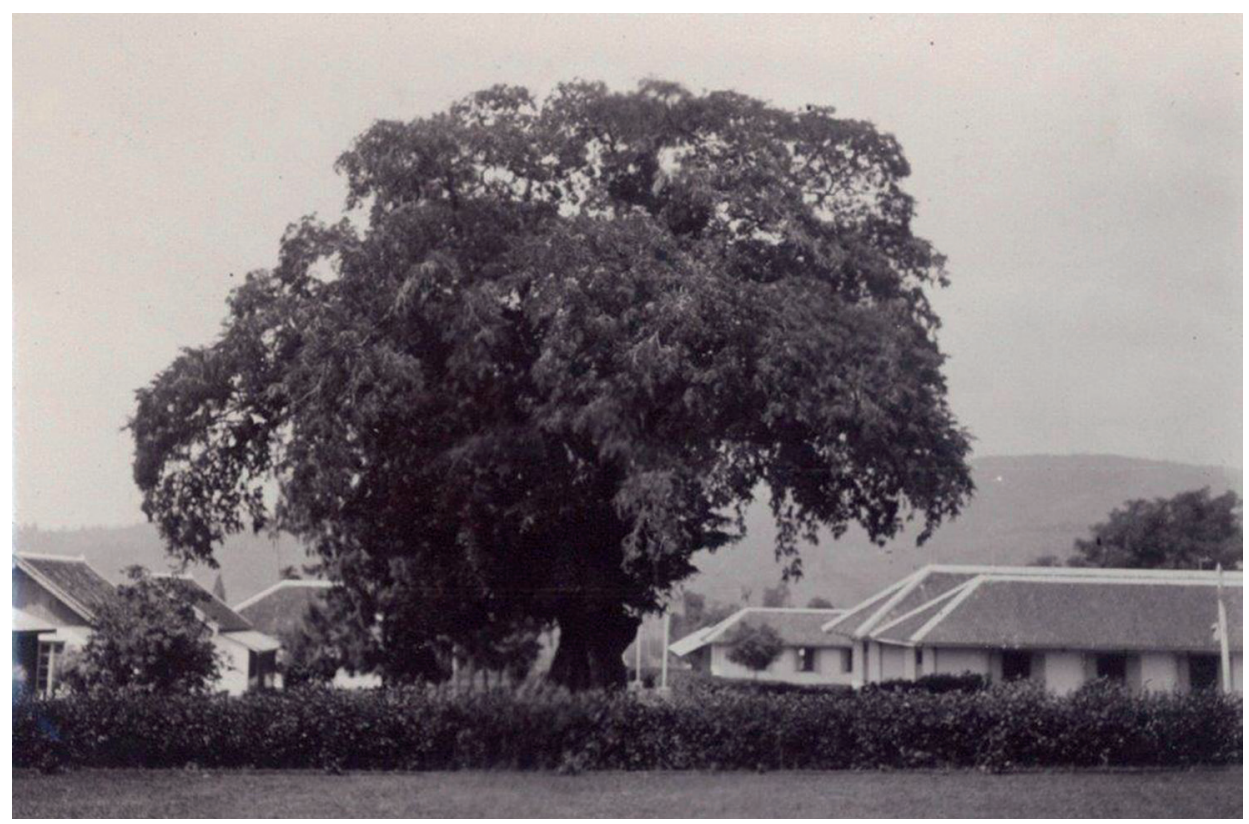

Figure 27 Psychiatric Hospital at Lawang 1912 (Source: KITLV)

Landbouwkolonie at Donggala (Celebes). All other psychiatric facilities were government institutions and the workers were civil servants.

In 1930, the psychiatric inpatient care had evolved to a system of institutions, most of which were established on Java (7 institutions and 6,651 beds). The nursing homes and one psychiatric hospital, together with 1,424 beds, were established in the Outer Provinces. The total capacity of psychiatric care was 8,075 beds. ${ }^{144}$ This almost equals the total capacity of 8,477 of the 93 public hospitals (CBZ, GBZ and municipal hospitals) at this time.

The Krankzinnigenwezen (Psychiatry) had become the largest branch of hospital care and had a separate position within the organization of the Public Health Service. From 1929, this branch had its own inspector (inspecteur van het krankzinnigenwezen in NI). The total finances earmarked for general government hospitals and outpatient clinics in 1930 amounted to $f 1.8$ million (of which personnel $f 583,000$ ), whilst the budget for all psychiatric institutions together amounted to $f 2.1$ million (of which $\mathrm{f} 967,000$ for personnel). ${ }^{145}$ These figures give an idea of the importance in terms of finances and personnel involved.

144 Indisch Verslag 1930, De sociale toestand, Gezondheidszorg, Krankzinnigenverzorging, 388.

145 Staatsblad van Nederlandsch-Indië 1930 no. 207: Begrooting 1930, Afdeeling V. Splitsing in artikelen van de posten van Hoofdstuk II (uitgaven in Indië), posten 570 en 570 A (Budget 1930, expenditure NI, budget posts 570 and 570A). 
Intensive use was made of all psychiatric facilities. The occupancy rate in 1930 was $97.8 \%$. The patient population consisted of $8 \%$ Europeans, $79 \%$ Indonesians and $13 \%$ other Asians. 7,902 occupied beds correspond with an asylum coefficient of $0.13 \%$. There were large differences between the different population groups though: the coefficient was 2.7 $\%$ for Europeans ( 650 on 240,000), $0.8 \%$ o for Chinese people (1029 on 1,233,000) and only $0.1 \%$ for the autochthonous population $(6223 \text { on } 59,138,000)^{146}$

The psychiatric facilities could be found in the following provinces (see Figure 28).
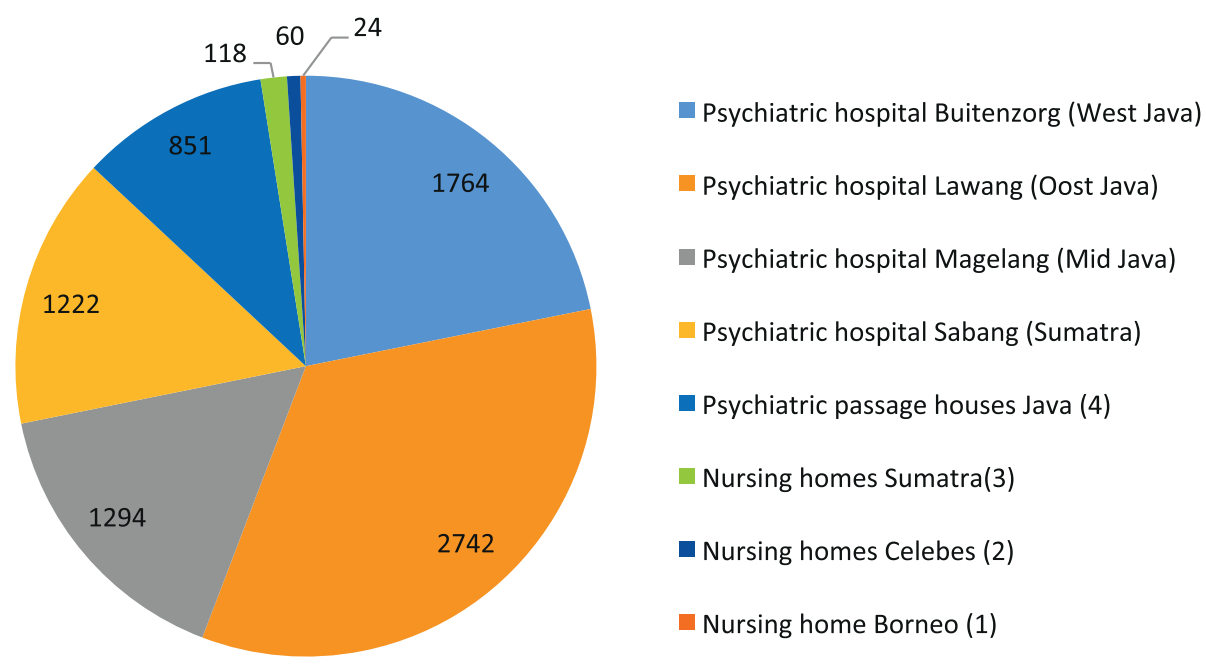

Figure 28 Psychiatric facilities 1930

\section{OUTPATIENT SERVICES}

In contrast to the subsidies provided for hospital care, organized by private foundations and associations, the government did not subsidize outpatient services. Yet the NI Government gave encouragement to private associations and missionary societies through free distribution of medical and nursing supplies such as pharmaceuticals and bandages. In places where private initiative failed to establish outpatient clinics, the Public Health Service started so-called Landspoliklinieken. However, a large part of the outpatient services was organized by central government hospitals and by government civil hospitals. The number of government outpatient clinics totalled 435 in 1930, compared to 229 general government hospitals (military included). ${ }^{147}$ Most general hospitals had one general 
outpatient clinic, so probably about 200 outpatient clinics were more or less independent (not depending on a hospital) Landspoliklinieken. An example of an outpatient clinic that had no link with a hospital was the one led by Sampoerno, the gouvernements indisch arts who took care of the Moehammadyah polyclinic at Batavia. Similar initiatives were supported at Soerabaja, where the doctors Sardjono and Soetomo successfully treated thousands of patients. ${ }^{148}$ From April 1927 to July 1929 Moehammadijah organized the socalled kampong health care. Six indigenous doctors visited kampongs at Bekassi, Tamboen and Kebajoran (neighbourhood of Batavia) and treated freely the population and propagated vaccination against smallpox, cholera and typhoid fever. ${ }^{149}$

Especially in the countryside, outpatient facilities were established to assist central hospitals. From the location of the hospital a large circle was drawn to cover a rather extensive neighbourhood for which auxiliary hospitals and outpatient clinics could serve. Mantri-nurses $1^{\text {st }}$ class under supervision of the hospital doctor were in charge of these facilities. This system was recommended by missionary doctors and by the NI government as well. The mantri-nurse took care of simple and everyday interventions such as treating wounds and eye infections or minor diseases and sometimes assistance in case of accidents. The nurse lived in the neighbourhood of the clinic and was able to provide daily care. Previously, doctors were not able to visit these outpatient clinics more than once a week or twice a month.

An example of such a mantri nurse is mentioned in one of the annual reports of the missionary hospital at Modjowarno: 'the mantri nurse Marijon replaced the doekoen mata Raden Soedjalma, who had received his training at the Eye Hospital of Bandoeng and who had been responsible for the important ophthalmic department at the hospital. Mr. Marijon took over from him and operated a large number of ophthalmic patients every Wednesday morning. Besides, he was charged with checking schools in the neighbourhood for schoolchildren with eye problems.'

Most of the missionary hospitals organized a number of outpatient clinics and so did some company hospitals. Although no numbers are mentioned, we may assume that like the government polyclinics, such outpatient clinics were managed by missionary and company hospitals and outnumbered the hospitals.

148 In 1929 the number of outpatient visits was 16,761. The name of dr. Soetomo is nowadays connected to the University hospital at Soerabaja.

149 Indisch Verslag 1930, Verzorging van geestelijke behoeften en sociale welvaartszorg uit Inlandschen Kring, p. 35-70 Transl.: Care of psychological needs and social welfare in indigenous circles. 


\section{SUMMARY}

The period 1910 to 1930 was characterized by an increasing demand for hospital and outpatient services. Looking at the developments in these 20 years, the dispersion of hospitals over the archipelago implied a better accessibility of these services for the population. The development of local hospitals, especially the ones initiated by municipalities and charity organizations, promoted decentralization. That the local population benefited from these facilities was obvious by the increasing use of hospital capacity. Political and religious indigenous movements like Moehammadijah joined in procuring free health facilities for the population.

Civilian society generated and maintained umbrella organizations that coordinated care and facilitated the necessary provisions. Two important associations accompanied the establishment of facilities for patients with leprosy and for patients suffering from tuberculosis. Not only the result of private initiatives characterized this period. The public hospitals were freed from the earlier image of providing rudimentary provisions for criminals and prostitutes. They were converted into well-provided rebuilt facilities with a doctor, some mantri nurses and other personnel with a civil servant status. These former syphilitic and general indigenous hospitals were transformed into government civil hospitals (GBZ). By 1930 a number of 78 had been established. The most striking development was the phenomenon of company hospitals. Their number increased tenfold, compared to the 1910 numbers, from 32 to 301. Putting into balance 20 years of building, closing and changing of destination, we may conclude that the joint picture of hospitals focussed much less on Java. The Outer Provinces saw an increase in hospital capacity that was more pronounced compared to Java in this period. When comparing the inpatient capacity with population numbers, it appears that Java (41 million) had about $0.3 \%$ o beds, whereas the Outer Provinces ( 18 million) had $0.55 \%$ o beds. As the Outer Provinces covered $85 \%$ of the surface of the Archipelago, the availability of hospital beds should be contemplated in the light of population density as well. The distribution of hospitals and beds in relation to areas and population will be studied in the next chapter.

Altogether, an important step forward was made in getting hospital care accessible to the population. Unfortunately, little statistic information is available on the 301 company hospitals, but even if we take the smallest bed capacity category for each of them, their joint capacity would exceed 8,000 beds. Adding this capacity to the 14,200 general hospital beds (Statistics KV 1930), the population of the Netherlands Indies could make use of 22,200 hospital beds, equalling $0.38 \%$.

As most of the company hospitals were established in the Outer Provinces and most of the government hospitals on Java and Madoera, the attribution of hospital capacity to either of these territories may only roughly be estimated to be 12,000 beds for Java and 10,000 beds for the Outer Provinces. This result was obtained, partly by political decisions (decentralization policy), partly by rational considerations (look at the Djokja model) and for a large part by economic motives. 



\section{CHAPTER 6}

A PERIOD OF DECENTRALIZATION (1930 - 1942) 


\section{INTRODUCTION}

Compared to the two previous periods (Chapters 4 and 5), an episode of turmoil followed by a phase of expansion, one of the characteristics of the period 1930 - 1942 was decline. The Great Depression not only influenced the Western world, but had a severe impact on Asian countries as well. Consulting successive annual editions of the Staatsblad (Statutebook) after 1930, the most salient item in the Table of contents is "Decentralization", often referred to as Ontvoogding (Emancipation). In the 1930s the decentralization process of administration, that had been promoted from 1910, became more or less completed. For the hospitals in the NI this process was sometimes accompanied by a transfer of status, from publicly owned and exploited organizations to private hospitals owned by missionary societies. Beside this privatisation trajectory, the government was keen on transferring the remaining public hospitals (GBZ) to lower administrations such as provinces, regencies or municipalities. During this process, health care budgets were often cut. Though contraction took place for public hospitals and company hospitals, there were also a few positive developments. First of all, there was the expansion of missionary hospitals, especially those managed by Roman Catholic organizations. Quite a few new specialized hospitals were founded, such as TB sanatoria and leprosy institutions. The latter were mainly on Bali as a result of the new policy of voluntary registration.

In the meantime, scientific innovations were introduced into medical practice, such as advanced diagnostics by hospital laboratories, introduction of departments of radiology, new pharmaceutical products, advanced surgical techniques, etc. These innovations were hardly present in the previous periods or only on a rather limited scale. The development of Western health care was brutally stopped by the Japanese occupation, which took away the European staff from all hospitals. The Europeans were interned in concentration camps, often situated in public buildings such as schools, military barracks and hospitals.

\section{EMANCIPATION AND THE STANDARD OF LIVING}

The ethical politics brought about many reforms during the 1920s. Some of these were successful, as can be witnessed by looking at the achievements in the fields of education, health care, agricultural and infrastructural developments. Some did not yield the intended progress. The decentralization of many projects often took place at a rather slow pace. After 1930, the attention of the NI government was focused on an acceleration of regional development. Local and regional councils regulated their affairs with fewer interventions and instructions from the central government. Budgets were decentralized and the dependence on Batavia and the central administration diminished. It was a planned policy, originating from the principles of ethical politics and emancipation, formulated some decennia earlier. Besides, it coincided with the gloomy economic prospects and this made it advantageous for the government to shift responsibilities to other levels and economize at the same time. 


\section{Countering rebellion}

Before 1930, the political movements that pursued independence encountered severe measures from the NI Government, which opposed their aspirations. Their leaders, Soekarno and Sartono, Hatta and Sjahrir attempted to acquire a new legal status by renaming the former political parties. A change into more moderate politics towards nationalism caused Governor-General A.C.D. de Graeff (1926-1931) to release Soekarno, the leader of the PNI, who had been arrested and condemned to four years of prison in 1929. However, this new attitude was not maintained, as the nationalists propagated a provocative line of non-cooperation. This attitude culminated in rebellion, when on 5 February 1933 the cruiser De Zeven Provinciën was hijacked. The new Governor-General, B.C. de Jonge (19311936) reacted fiercely and the measures taken resulted in repression of all opposition in meetings, papers or otherwise. ${ }^{1}$ As more of the NI youths followed secondary and even higher education, the opposition against the Dutch colonial regime did not weaken but became a serious problem to the central and regional colonial authorities. Although the most notorious rebellions took place in the 1920s, the Koloniale Verslagen continued to mention uprisings and conflicts in the 1930s. Further, the authority of the old native rulers waned. It required considerable effort to implement effective rule in some regions. Furthermore, the regional administrators sometimes had to interfere with questions of succession of the old nobility. The principle of heredity often implied that inadequate rulers took over the duties of their predecessor, father or uncle, who had been in charge of regional administration as regent or otherwise. ${ }^{2}$

Towards the end of the 1930s, economic circumstances improved, but the insecurity and the threat of war compelled the NI Government to reinforce the army and navy, allocating considerable amounts of money for defence.

\section{Welvaartsdiensten ${ }^{3}$}

In 1930, a well- prepared census covering all parts of the Netherlands Indies showed that the population of Java had grown to 41.7 million, while the Outer Provinces counted about 19 million. Compared to these numbers, the results of transmigration from Java to less densely populated areas were meagre. By 1940, the size of the population of transmigration colonies totalled 210,679. ${ }^{4}$ The so-called Welvaartsdiensten, especially represented by the Department of Agriculture and the Agricultural Research Station at Buitenzorg aimed at enlarging and intensifying agricultural production and expansion of the productive acreage.

1 De Jong, De waaier van het fortuin, 538-541.

2 Several memories van overgave (Memorandum of transfer of office) of leaving Residents, addressed to their successors, mention these difficulties.

3 The Welvaartsdiensten comprised Irrigation, agricultural extension service, credit services, cooperative services, housing, transmigration, etc.

4 P. Boomgaard, A.J. Gooszen, Changing Economy in Indonesia, Vol. 11, Population Trends 1795-1842. Table n mentions colonies in the Residencies of Lampung, Benkoelen, Sumatra's East Coast, Palembang, Jambi, Celebes and Borneo. 
One of the effects of this policy was that, whereas the population tripled between 1868 and 1940, the rice production increased by a factor 3.2. This prevented the famines that occurred in other colonies, such as British India.

According to De Jong the archipelago had a modern, western educated and trained Indonesian administrative class by the end of the 1930s. The author mentions that this was one of the positive side-effects of the decentralization policy. ${ }^{6}$ However, the results of Education proved to be insufficient: the number of the population that received secondary and higher education during the 1920s and 1930s was small. On 1.8 million pupils in 1931, most (1.7 million) received only vernacular basic education and only 16,000 received secondary or higher education. ${ }^{7}$

\section{The effects of the economic depression}

The Netherlands Indies was among the chief victims of the depression as the colony was exposed to the effects of reduced world demand and the increasing protective measures. The internal market and the homeland could not absorb the usual export products and was not prepared to issue import duties. During the first half of the 1930s, the crisis forced the government to cut back on all budgets, including those for welfare services. In 1930, the welfare services' budget amounted to $f 119$ million. In 1935 it had been reduced to less than half, to $f 55$ million. ${ }^{8}$ During the first five years of this period, the labour flow from Java to the Outer Provinces was reversed: some 152,000 Javanese labourers returned. Despite the rapid population growth, the archipelago managed to achieve a higher degree of selfsufficiency in food than previously. After 1936, there was indeed surplus of rice. ${ }^{9}$ At the same time, the availability of land for growing food increased, as the land was no longer needed to grow export crops such as sugar. ${ }^{10}$ Boomgaard studied the views of economists, some of whom sharply differed in evaluating the damages caused by the Depression. According to this author, the years 1933 to 1935 were the worst as far as Java was concerned: "During those years, bad weather conditions- causing harvest failures in many areas- hit Java at the very moment that the depression was about to bottom out." The author concluded that many people faced hardships during these years, but he considered it an exaggeration to regard the depression as a period of great suffering for the Indonesian, particularly, Javanese population. ${ }^{11}$

\footnotetext{
De Jong, De waaier van het fortuin, 422.

Ibidem,527.

J.S. Furnivall, Netherlands India, a study of plural economy, table on p.377.

Ibidem, 509

P. Boomgaard, Changing Economy in Indonesia, Vol. 11, Table m.

10 Allen \& Donnithorne, Western enterprise in Indonesia and Malaya, 35.

11 P. Boomgaard, "Surviving the Slump: Developments in real income during the depression of the 1930s in Indonesia, particularly Java “, in: P. Boomgaard and I. Brown ed., Weathering the Storm, The Economies of SE Asia in the 1930s Depression (Leiden 2000).
} 


\section{THE PUBLIC HEALTH SERVICE (DVG)}

Before commencing to discuss the development of hospitals from 1930 to 1942, it is necessary to elaborate on the issue of the Public Health Service or DVG (Dienst voor de Volksgezondheid). During the 1930s, this Service was characterized by increased attention for rural hygiene and loosening of ties with direct health care. In the preceding Chapters, the Service (then called Civil Medical Service or BGD) more or less coincided with direct health care. At least, the largest part of its budget was spent on direct care.

\section{From direct health care to rural hygiene}

The focus of the Civil Medical Service on direct and curative health was left only reluctantly. Since 1924, when the Dienst der Volksgezondheid or DVG (Public Health Service or PHS) was established, its main mission was to improve public health. However, for quite some time the accent of its activities continued to be placed on hospitals, dispensaries and treatment campaigns. This stemmed from the interest of many medical doctors, the curriculum they had attended at university and their practical experience. On paper the involvement of the Government in organizing Western-type curative health care diminished. However, just as earlier and since the Military Medical Service era, the central government continued to facilitate the supply of medicines. Often this resulted in exceeding of the budgets. ${ }^{12}$ At the same time, the government maintained functions as the inspection of health care institutions. Moreover, the Public Health Service trained and continued to maintain a network of vaccinators assigned to smallpox vaccination districts. The Public Health Service was responsible for the upkeep of the main laboratories in the 3 main cities of Java and of the Lands Koepokinrichting and the Institute Pasteur. The latter two institutions produced vaccines (against smallpox, cholera and rabies) and organized courses in inoculation techniques for vaccinators. Thus, the Lands Koepokinrichting managed to provide the Public Health Service with a trained team of 421 vaccinators (158 on Java and 263 in the Outer Provinces) by $1934 .{ }^{13}$ The Public Health Service took charge of the training of health care professionals and of the organization of relevant examinations. Apart from these functions, the PHS inspectors implemented the execution of health legislation, in particular the plague and cholera ordinances. In other words, the Public Health Service had to fulfil many tasks and so it took some time to reduce the focus on direct health care duties. It lasted to the mid-1930s, when finally, the involvement of the Public Health Service in direct health care was reduced to the 3 central government hospitals, to some of the Government Civil Hospitals (GBZ) and to the psychiatric institutions.

12 Apart from a central supply of medicines to civil servants and missionary lay people, especially in thinly populated areas, hospital pharmacies and local pharmacies supplied medicine under supervision of a pharmacist or medical doctor. The central supply took place from the algemeen magazijn voor geneesmiddelen at Batavia, later on this store moved to Bandoeng (1908). In 1929 the budget of the DVG was exceeded by $f$ 544,000, mainly due to higher costs of medicines.

13 Publication Public Health Service (DVG 1934), IV Health, Table 41. 
Whereas the NI government diminished, step by step, its influence and participation in direct health care, a foreign agency tried to further public hygiene issues, in many places in the world, including the Netherlands Indies. It was called the Rockefeller International Health Board Foundation (IHB). This American foundation, founded by John D. Rockefeller in 1913, set out "to promote the well-being of mankind throughout the world" and started with investigations on the prevalence of hookworm. The IHB extended these campaigns into tropical areas in Africa and Asia, together with subsidies of schools and institutes of public health and tropical medicine. ${ }^{14}$ A representative of the IHB, the American doctor John Lee Hydrick (1888-1958), made a survey of the situation in the Netherlands Indies. J.L. Hydrick wanted to make a proposal for intensive hygiene work, but was frustrated by the lack of cooperation from the health authorities in the NI and the xenophobic attitude of the Dutch. Nevertheless, Hydrick continued his work in the Netherlands Indies from 1924 to 1939 and after 14 years of public health activities, he informed the Rockefeller Foundation: "The Dutch have done a better administrative job than any of the other colonial administrations in the Far East...., by introducing a decentralization of government in 1937."15

Gradually, the Public Health Service took over the ideas of Hydrick and built up systematic information campaigns to stimulate the use of latrines and mosquito nets and the boiling of drinking water. ${ }^{16}$ The Service issued instructions for pregnancy and infant care and for hygiene in schools. This type of information and education services was called Intensief hygiënewerk, a translation from the American 'Intensive rural hygiene work.' These Intensive Rural Hygiene activities of the Public Health Service resulted in the establishment of the Regency Health Service Demonstration Centre at Poerwokerto, which was founded together with a training centre for hygiene mantri. ${ }^{17}$ These activities received much interest from NI government officials, from neighbouring countries and from the League of Nations Health Organization. The Far Eastern Bureau of the latter organization requested to borrow the Bandoeng Exhibition material for demonstration purposes in the countries of East Asia. ${ }^{18}$ The Demonstration service at Poerwokerto organized many preventive activities, such as home-visits, mother and child care, instructions on nutrition, soil and water pollution, inspections of houses, markets, bakeries, etc. The Service was also engaged in research projects on malaria, puerperal fever and tuberculosis.

14 Frances Gouda, Discipline versus Gentle Persuasions in Colonial Public Health: The Rockefeller Foundation's Intensive Rural Hygiene Work in the Netherlands East Indies, 1925-1940 (Amsterdam 2009).

15 Han Mesters, "J.L. Hydrick in the Netherlands Indies, an American view of Dutch public health policy", in: P. Boomgaard, R. Sciortino and I. Smyth, ed., Health Care in Java, Past and Present (Leiden 1996) 51-62.

16 Frances Gouda quotes Hydrick: "The people should be lead, not driven. They should be stimulated and learn to express a desire to live more hygienically. It is the task of the health worker to create this desire."

17 Peverelli, De zorg voor de volksgezondheid, 23.

18 This exhibition was organized on the occasion of the 1937 Conference of the League of Nations on Rural Hygiene at Bandoeng. 


\section{Further decentralization of health care}

As the Public Health Service was on its way to loosen its ties with direct health care, this process was furthered by the decentralization of hospitals, which now accelerated. Before 1930, many government decisions had been taken and regulations had been issued on plague, cholera and tuberculosis containment. Places for quarantine had been assigned and data on the occurrence of infectious diseases had been exchanged regularly on an international scale. Attempts had been made to register causes of death and to give death certificates. ${ }^{19}$ After 1930, new regulations were added to the existing ones on the issuing of birth and death certificates in several towns and regions. These regulations had to do with law and order issues and facilitated the improvement of mortality statistics.

In 1936, the final measures were taken to transfer central functions of the Public Health Service, especially those regarding individual health care, to provinces, municipalities and autonomous communities. As expressed in the NI Statutebook no. 582 of 30 October 1936:

1. City councils and regencies will have responsibility for the establishment and upkeep of public outpatient clinics and public hospitals;

2. Public local hospitals will serve mainly the medical treatment of poor indigenous patients;

3. The Central Government will have responsibility for the upkeep of the central civil hospitals at Batavia, Semarang and Soerabaja, including the connected outpatient departments.

4. Provinces will have responsibility for the establishment and upkeep of other public hospitals and outpatient clinics.

The mission for the provinces was meant to be temporary, as it was stated that in less than one year their initial commitment would be transferred to city councils and regencies. The local and regional public hospitals could receive the necessary medicines, sera and vaccines from the Central Pharmacy Store ('s Lands voorraad). Not only the responsibility of hospital care was transferred to the local and regional administrative levels, but also Bodemassainering (soil sanitation), Drinkwatervoorziening (drinking water supply) and Afvalverwijdering (waste disposal).

\section{Personnel Public Health Service}

In the 1920s considerable effort was made to increase the number and kind of professional health care workers. However, the training facilities could hardly keep up with the growth of hospitals and other health care institutions. From 1930, there were new developments:

19 Based on the so-called Doodschouwordonnantie (Ordinance on death certificates) for the indigenous population and for Vreemde Oosterlingen (Foreign Asians), published in the NI Statutebook no. 612 of 27 September 1916. The implication of this Ordinance was to prohibit burying of deceased persons in absence of a written certificate stating the cause of death and signed by an authorized person. 
The Geneeskundige Hogeschool and other schools began to deliver graduates. During the course 1939/1940, the Geneeskundige Hogeschool had 700 students, of whom 47 graduated. During the course 1940/41 this number increased to 57. From 1934, when the first graduates left the Hogeschool up to and including the first months of 1942, there were a few hundred graduates from the Faculty. In 1935, the Stovia closed its doors, having trained 700 indigenous doctors during its existence (1851-1935). ${ }^{20}$ From 1935 to 1942 the other school for indigenous dokters (NIAS) at Soerabaja continued to train students and doubled the number of graduates during this period. A report, published immediately after the war, stated that there were 250 Nias-graduates in professional practice shortly before the war. ${ }^{21}$ About 1937, the different training opportunities of the Public Health Service focussed on training mantri-nurses, $1^{\text {st }}$ class mantri and midwives. All of these training facilities were located at the 3 Central Civil Hospitals (CBZ) at Batavia, Semarang and Soerabaja. Mantrinurses were trained at the Government Hospitals (GBZ) at Menado, Singaradja and Tandjong-Pinang as well. Additional training of midwives took place at the GBZs at Semarang and Soerabaja, at the Government Maternity Clinic at Medan and the private institution Boedi Kemoelaän at Weltevreden. Many private hospitals and clinics worked together to facilitate midwifery training. This joint effort with the public hospitals led to 78 midwives graduating in 1937.22

The school for pharmacy assistants had delivered a total of 134 licensed pharmacy assistants from its start to 1930. In the course of this decade, a new development changed the employment situation: a lot of Dutch pharmacy assistants had lost their jobs and looked for opportunities in the colonies. This implied that many European pharmacy assistants applied for an Acte van Toelating (acceptance of qualifications) in the NI. In 1937 their number increased to 64 , which represented $53 \%$ of all admitted assistants. At the same time, the number of newly licensed pharmacy assistants grew, 31 pupils graduated in 1937. ${ }^{23}$

In 1930, the school of dentistry at Soerabaja had 42 students, most of them were Chinese and half of the students were female. The duration of this training for indigenous dentists was five years. In 1938, the number of pupils had almost doubled to 81 .

A training of laboratory assistants was organized at the Centraal Laboratorium of the PHS (Medical Laboratory) at Batavia. Licenses could be obtained after three years of training.

At the start of the decade 31 assistants had graduated. The training differentiated between chemical analysts and bacteriological analysts. The training capacity was limited in 1938

20 L. Hesselink, Healers on the Colonial Market, 158-159 and A. de Waart, "Het Indisch Geneeskundig Onderwijs in de laatste 25 jaren", Feestbundel GTNI 1936, 246-257. Transl.: Medical training in NI in the last 25 years.

21 R.D.G.Ph. Simons, "De geneeskundige taakverdeling in Indië kort voor en terstond na den oorlog”, NedTijdschr Geneeskd. 90 (1946) 87-873. Transl.: Medical job division shortly before and immediately after the war.

22 Mededeelingen Dienst der Volksgezondheid XXVIII (1939) 2-3: 61.

23 Mededeelingen Dienst der Volksgezondheid XXVIII (1939) 2-3: 113. 
to only 8 students on the course of bacteriological analysis and the same number on the chemical analysis course.

Considering the general trend in the period 1930-1942, a continuing growth of health care workers can be observed, even in a period largely characterized by economic stagnation and budget cuts. In order to obtain some idea about the number of staff, employed by the Public Health Service, Peverelli published the figures for 1936 (see Figure 29). ${ }^{24}$ This author arrives at a total of 3,135 for the central office, the central public hospitals, the psychiatry institutions and several auxiliary services. ${ }^{25}$

\section{Staff Public Health Service}

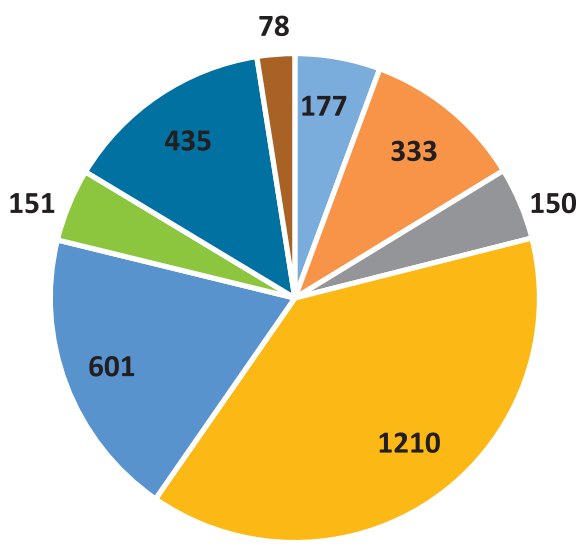

European doctors

- Other doctors

- European nurses

Other nurses

- Mantri special services

- Midwives

- Vaccinators

- Other

Figure 29 Staff Public Health Service in 1936 (Source: Peverelli, 99-100)

\section{Finances Public Health Service}

Whereas the years 1910-1930 could be characterized by continuing growth and budgetary expansion, the opposite occurred in the period after 1930. Positive headings such as Ontvoogding (Emancipation) used in decentralization policies, covered up the real issue. The NI government had to economize considerably, budget cuts affected most departments, including the Department of Education and Worship. ${ }^{26}$

Table 13 shows both tendencies, expansion from 1910-1930 and cuts from 1930 onwards. After 1937, the NI Government budget recovered. There was an increase in the health

24 Peverelli, De zorg voor de Volksgezondheid, 96-101.

25 This only represents part of the total health care manpower, a larger part being employed by the military, mission, company and other private hospitals.

26 The Public Health Service belonged to this Department. 
budget to the 1920 level. A large part of the general budget rise was accounted for by allocations to the Departments of War and Navy. The reason why the health budget only moderately benefitted from the general rise may have been due to the decentralization process. The Department of the Interior accounted for the budgets of municipalities, provinces and residencies. From 1930, the Health budget itself showed the expenditure for Public Health Inspectors, Central Civil Hospitals and Psychiatric institutions.

Table 13 NI Government Budget 1910-1939 (million $f$ )

\begin{tabular}{lrccccc}
\hline Description & $\mathbf{1 9 1 0}$ & $\mathbf{1 9 2 0}$ & $\mathbf{1 9 3 0}$ & $\mathbf{1 9 3 5}$ & $\mathbf{1 9 3 7}$ & $\mathbf{1 9 3 9}$ \\
\hline Total & 172 & 457 & 681 & 358 & 276 & 550 \\
Education \& Worship & 13 & 40 & 82 & 36 & 24 & 33 \\
Health & 3 & 13 & 21 & 12 & 10 & 13 \\
\hline
\end{tabular}

Source: Begrotingen van Uitgaven in NI (Expenditure budgets) as published in the Statutebooks of those years

\section{HOSPITALS 1930-1942}

The transfer of public civil hospitals from the central government to local and regional councils progressed during the 1930s. A considerable number of hospitals changed their legal status from a government-owned hospital to one run by a municipality, by a community, by the Roman Catholic or Protestant mission or by an autonomous administrative body. For example, in 1934, one municipal hospital (Soekaboemi) and four government civil hospitals (GBZs) (Pekalongan, Pemalang, Malang and Wonosobo) were taken over by a missionary organization. ${ }^{27}$ The Public Health Service reported in the years 1936 and 1937 that 32 of the 55 Government civil hospitals had been transferred to local authorities on Java and Madoera as from 1 January $1937 .{ }^{28}$ In 1930, the NI Government administered 46 hospitals on Java and 31 in the Outer Provinces. In 1938, this number was reduced to 17 for the entire archipelago. In 1940, the Public Health Service reported only 2 remaining Government Civil Hospitals (GBZs). ${ }^{29}$

The central public hospitals at Batavia and Soerabaja provided top-clinical care and in these cities there were facilities to train indigenous and fully qualified medical doctors. Hospitals in the other parts of the archipelago had more basic facilities. There were some exceptions though, such as the Djokja experiment and some stratification experiments on the East Coast of Sumatra by plantation owners. Apart from these examples, the real hospital scene was dominated by small basic hospitals, outpatient clinics and auxiliary hospitals.

\footnotetext{
27 Indisch Verslag 1935 (Netherlands Indies report 1935) 291-292.

28 Mededeelingen DVG XXVIII (1939) 2-3: 57-136.

29 Mededeelingen $D V G$, as reported by Kits van Waveren, 3445.
} 
As described in chapter 4, the Reorganization Commission of 1906 had referred to the network of medical districts with the idea that the settlement of doctors per medical district should be accompanied by the establishment of small hospitals (about 10 beds) or wellprovided outpatient clinics. Consulting the Regeeringsalmanak 1930, a total of 247 medical districts were designated (111 for Java and 136 for the Outer Provinces) with roughly one doctor per district. However, although the plans had been formulated, the overall introduction took time, as the transfer of hospitals from government level (Central Civil Hospitals and Government Civil Hospitals) to provinces, municipalities and local authorities was delayed for decades.

\section{Some general characteristics of NI hospitals}

As the development of public and private hospitals for civilians progressed, more or less similar features of a modern hospital could be established. These characteristics were not yet distinctive in the previous periods, when many civil hospitals still had to release their past images as hospitals for prisoners and prostitutes. From the mid-1920s and still more in the 1930s these historic marks were removed and the modern hospital emerged. This process was promoted by the Civil Medical Service as owner of public hospitals and by the conditions private hospitals had to meet for being awarded subsidies. Civil servants as Residents and Controleurs regularly had to check the hospitals in their resorts, whether they still could meet the requirements of public and private hospitals. Some of these characteristics and requirements will be discussed in the next paragraphs.

\section{The internal organization of the hospitals}

In chapter 4 the criteria were discussed that hospitals had to meet in order to apply successfully for subsidy. These hospitals were scrutinized by local administrative authorities, which verified if the subsidy criteria were met. Subsequently, regional and local administrators (Residents, Assistant-Residents and Controleurs) were responsible for looking after the quality of buildings, personnel, equipment and nourishment of patients. Previously, the aim of the Public Health Service had been to improve the quality by enlarging the staff and by attracting more qualified personnel, thus trying to get rid of the bad image these institutions had as former hospitals for prisoners and prostitutes.

In the instruction to directors of the central government hospitals, the medical director was appointed as head of all personnel. This functionary was responsible for the internal organisation of the main hospital departments: operation theatres, outpatient department, nursing departments and, if available, laboratory personnel and the pharmacy. In the smaller hospitals the medical director supervised the auxiliary departments too. In the much larger central hospitals, supervision of departments such as laundry, kitchen, store rooms and bookkeeping was delegated to an administrator. In the psychiatric hospitals 
a so-called hoofd huishouding (chief housekeeper) was charged with these last duties. ${ }^{30}$ As the objectives of hospital organizations were similar, whether established in The Netherlands, Great Britain or the colonies, their internal organization did not differ much. Only in the division of responsibilities among European and indigenous personnel were variations found that did not exist in Western countries. This was noticeable in the titles of functions: Nurses (European) existed beside mantri-nurses (indigenous). Medical doctors (European) were found next to dokters djawa or indigenous doctors.

\section{The patients of the hospitals}

Before 1930, the usual disease pattern prevailed (malaria, eye and skin diseases and venereal diseases). During the 1930s, the same pattern could be distinguished but also tuberculosis, a disease that was more frequently diagnosed in the 1920s and 1930s than previously (See Figure 30).

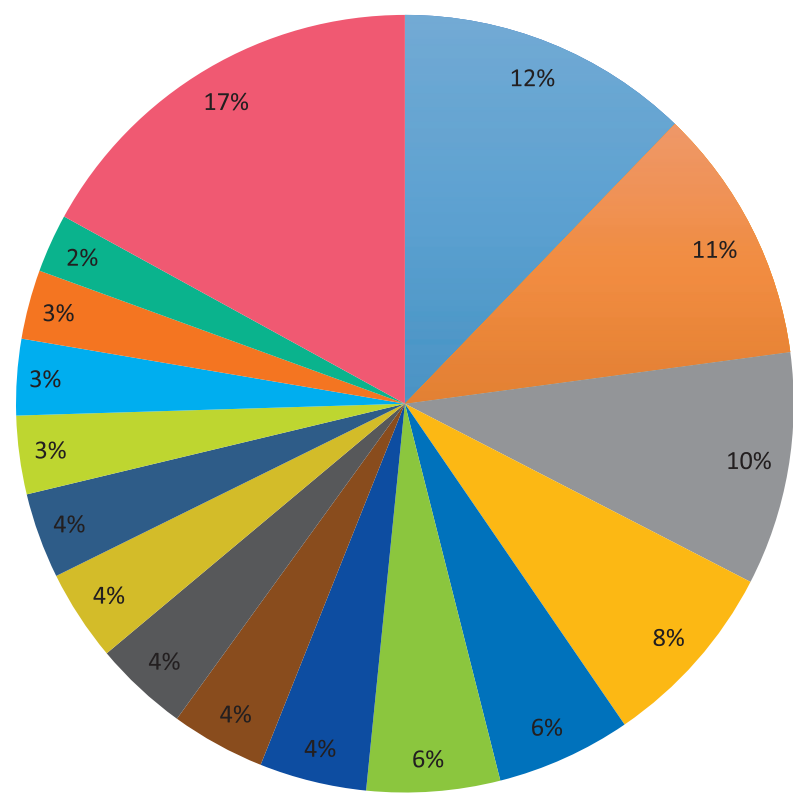

- Skin diseases, bones, locomotive organs

- Violent accidents, murder, suicides

- Malaria

- Venereal diseases

- Mother \& child

- Diseases of the organ of sight

n Diseases of the digestive system

- Framboesia tropica

- Tuberculosis

- Other infective diseases

- Bronchitis, pneumonia

- Genito urinary system

- Ankylostomiasis

- Influenza

- Dysentery

- Other diseases

Figure 30 Disease type and \% admissions in 1938 in 167 hospitals ( Source: Indisch Verslag 1938, table 45 (Report NI 1938).

30 Decision Head DVG of 21 February 1930 no. 5395/D (Supplement NI Statutebook 1930, no.12290). 
In the previous chapter a summary statement was made on the prevailing diseases and kind of patients admitted into a limited number of hospitals (see Table 8). In Figure 30 a few developments are noticeable: Cholera and smallpox are not mentioned any more. Malaria and syphilis continue to play an important role in the number of admissions. Skin diseases, etc. take primacy in admissions and violent accidents, etc. appear as a new and important category ( $2^{\text {nd }}$ place). Together, these four categories account for $40 \%$ of the total number of admissions. The mortality in these categories is relatively low, except for murders and accidents. The mortality of tuberculosis patients, of digestive diseases and lung diseases and of dysentery cases together took almost $40 \%$.

The death \% of tuberculosis was high, but seemed to decrease compared to the 1920 s (18\% compared to $25 \%$ ). The number of patients admitted with the diagnosis dysentery was reported before (see the paragraph on patients of chapter 5 and comment on Figure 16). In 1938, the admission percentage for this category of diseases was rather low (2.4\%), but the mortality rate for hospital stay was high: $10.3 \%$.

In order to obtain some idea on individual hospital performance, I chose two hospitals which had known a rather long period of existence, both dating from the 1890s. During this period, they managed to achieve expansion and innovations. I believe they are representative for the category of private charity hospitals.

The first one is a rather small hospital (65 beds), but very well-known, the Diaconessenhuis at Batavia, which in 1931 reported the usual interventions of six medical specialties: surgery and gynaecology, ophthalmology, internal diseases, ear, nose \& throat (ENT), paediatrics and dermatology (see Table 14). ${ }^{31}$ The hospital had an X-ray department, up-to-date operation theatres and a number of 25 European nurses.

Table 14 Admissions Diaconessenhuis 1931 by specialist

\begin{tabular}{llllllc}
\hline & $\begin{array}{l}\text { Surgery \& } \\
\text { gynaecology }\end{array}$ & Eye surgery & $\begin{array}{l}\text { Internal } \\
\text { diseases }\end{array}$ & $\begin{array}{l}\text { Ear, Nose } \\
\text { \& Throat }\end{array}$ & Paediatrics & $\begin{array}{l}\text { Skin \& } \\
\text { venereal } \\
\text { diseases }\end{array}$ \\
\hline Admissions & 237 & 636 & 630 & 187 & 178 & 2,136 \\
Inpatient days & 1,454 & 5,877 & 1,031 & 1,483 & 299 & 23,692 \\
\hline
\end{tabular}

Note: General surgery and Eye surgery were performed by 1 specialist. Internal diseases by 3 specialists. ENT by 3 specialists; Paediatrics by 2 specialists and Skin \& Venereal diseases by 2 specialists

Looking at the admission categories, the categories skin \& venereal diseases seem to be overrepresented: $53 \%$ compared to $20 \%$ for the same categories in figure 30, which represented 167 hospitals. The average length of stay of the inpatients was rather short for

31 Gedenkboek 40 jaar ziekenverpleging Koningin Emma Ziekenhuis ("Tjikini”) Vereeniging voor ziekenverpleging in NederlandschIndië 1895-1935 (Memorial volume 40 years of nursing, Queen Emma Hospital “Tjikini”). 
that time: 11 days. The Diaconessenhuis had another peculiarity, its services were mainly available for Europeans. The hospital had a training facility for European nurses, which was recognized by the Nederlandsche Bond voor Ziekenverpleging (Dutch Union of Nurses) ${ }^{32}$. The second hospital is the Modjowarno hospital that had a history of 40 years of development and growth as the first missionary hospital in 1894 in the Netherlands Indies. On the $40^{\text {th }}$ anniversary of the Modjowarno hospital in 1934, the hospital issued a memorial publication, in which the statistics for year 1933 were presented. In that year, the hospital had 284 inpatients on average with four main groups of patients: the group of epidemical or communicable diseases with 1,915 admissions (44\%) was the largest. This group included malaria (168), tuberculosis (251), venereal diseases (680). The second large group was Neuro-psychiatric and sense organs with 907 admissions, mostly eye diseases (21\%). Skin diseases followed with 439 admissions (10\%) and digestive diseases with 361 admissions ( $8 \%$ ). (See Table 15). The hospital reported on average 284 in-patients and a capacity of 300 beds. This means a bed occupancy rate of almost $95 \%$. The number of nursing days was 104,005. The 284 in-patients had an average length of stay of 24.2 days. More than twice the length of stay compared to the Diaconessenhuis.

Table 15 Diseases treated by Modjowarno Mission Hospital, 1933

\begin{tabular}{llcc}
\hline & Disease Group & Number of patients & Deceased patients \\
\hline I. & Epidemical or communicable & 1,915 & 90 \\
II. & Neuro-psychiatric and sense organ & 907 & 7 \\
III. & Cardiovascular & 46 & 7 \\
IV. & Respiratory diseases & 148 & 17 \\
V. & Digestive diseases & 361 & 12 \\
VI. & Genito-urinary diseases & 169 & 9 \\
VII. & Maternal conditions & 81 & 9 \\
VIII. & Skin diseases & 439 & 5 \\
IX. & Musculo-skeletal diseases & 18 & 2 \\
X. & Congenital anomalies & 12 & 1 \\
XI. & Childhood cluster diseases & 29 & 6 \\
XII. & Geriatric diseases & 2 & 1 \\
XIII. & Poisonings & 11 & 4 \\
XIV. & Injuries & 147 & 4 \\
XV. & Unknown & 25 & \\
XVI. & Healthy newborns & 55 & $\mathbf{1 7 4}$ \\
\hline Total & & $\mathbf{4 , 3 6 5}$ & \\
\hline
\end{tabular}

Source: A.P. Ketel, 1894-1934, veertig jaren Medische Zending, Zendingsziekenhuis te Modjowarno

32 C. Dane, Geschiedenis van de ziekenverpleging (Lochem 1980): This union of nurses was founded in 1893, aiming at promotion of the profession of nursing in all aspects. In 1907 a petition was sent to the Dutch government to supervise the training and to acknowledge the certificates of nurses. It lasted to 1921 before this was attained. 
The two hospitals (Diaconessenhuis and Modjowarno) had in common that they survived 40 years on their own without the secure position of a government hospital or the support of a substantial company. Their profile resembles that of a modern hospital with essential specialisms and equipment. Both invested in training of health care professionals. The Diaconessenhuis was much smaller and focused on a European patient flow, while the Modjowarno mission hospital was large (300 beds) and had only indigenous patients. Both hospitals were popular with the public and manifested progress in obtaining new functions and expansion of capacity. They proved their viability in the years of economic depression.

\section{Other hospital services rendered}

Before 1911, when the military hospitals dominated, auxiliary services were seldom mentioned for civil hospitals, with the exception of the laboratories in company hospitals on Sumatra's Eastcoast. Some of the laboratories mentioned, were central or regional research laboratories. From the 1920s, when important innovations took place and schools started to train laboratory and pharmacy assistants, these auxiliary hospital facilities became standard. The central civil hospitals had their own laboratories, as did most of the central missionary hospitals, central company hospitals and some of the larger civil government hospitals (GBZs). The emergence of modern well-equipped hospitals during the 1930s is demonstrated by the development of pharmacies, laboratories and x-ray departments as integral parts of the modern hospital organization. Despite the financial cuts, the modernization of hospitals continued.

\section{Pharmacy}

For many years, medicines and bandages were delivered free of charge from the central depot at Bandoeng. From 1911, when the Military Medical Service and the Civil Medical Service were separated, the store for medicines fell under CMS management, but for hospitals with sufficient capacity to employ a pharmacist, separate hospital pharmacies were set up. Pharmacies existed only in the 1930s in larger hospitals such as the Petronella, Modjowarno, the central public hospitals and some central hospitals of the plantation belt on Sumatra. Information was not systematically gathered about the incorporation of pharmacies into smaller hospital organizations. Subsidized hospitals could draw from Public Health Service-pharmacies or the Military Health Service for a total amount of $f 120,000$. Actually, the three Central Government Hospitals (CBZs) of Batavia, Semarang and Soerabaja had rather large hospital pharmacies. The Salemba pharmacy at Batavia had a budget that even exceeded the Batavia CBZ budget. The Netherlands Indies budget for 1939 gives an amount of $f 711,000$ for the three CBZ pharmacies together, compared to a total hospital budget of $f 1,519,420$ for these three hospitals. ${ }^{33}$

33 “Begrooting 1939 Afdeeling VA Dienst der Volksgezondheid”, Staatsblad van Nederlandsch-Indië 1939 no. 594 (NI Statutebook 1939 no. 594). 
At the end of 1938,78 private pharmacies existed in the archipelago with 82 pharmacists and 246 assistant pharmacists (78 of whom were female). The number of pharmacy assistants who received a NI licence in 1938 was 45 and those who received a Dutch certificate $27 .{ }^{34}$ In 1934, about $10 \%$ of the pharmacy budget was spent on neo-salvarsan and $18 \%$ on the purchase of quinine. The exact number of hospital pharmacies was not given in the Public Health reports of that year.

\section{Laboratory and X-ray departments}

In the discussion of the central company hospitals many well-equipped laboratories were mentioned. Apart from the usual hospital laboratories, one central Pathological Laboratory was established by several plantation companies together on Sumatra's East Coast at Medan in 1906. Unfortunately, there is no information available on the size and number of the different clinical laboratories in that region. On Java a few central and regional laboratories existed at Batavia (Eykman Institute), Semarang and Bandoeng (Landskoepokinrichting and Institute Pasteur). The NI budget 1939 mentions a total expenditure of $f$ 439,000 for these laboratories. Probably, in the case of the majority of the hospitals, laboratory tests were contracted out to central or regional laboratories. An indication of this may be deduced from a survey of average personnel for government civil hospitals (GBZs) of different sizes: Even for the largest category (241-288 beds) no laboratory assistants are given, while pharmacy assistants appear for hospitals with a capacity of $49-96$ beds. $^{35}$

The three central government hospitals took care of the training of laboratory assistants. The Eykman Institute, Central Laboratory of the public health service at Batavia, organized a training for chemical and bacteriological analysts. ${ }^{36}$ In the 1934 floorplan of the mission hospital at Modjowarno (a 300 beds hospital) a laboratory is shown, beside an electromedical department and a pharmacy. ${ }^{37}$ The Municipal Hospital at Bandoeng contained a pharmacy and laboratories in the new buildings. ${ }^{38}$

In the sanatoria for tuberculosis and probably the large central public hospitals, facilities were present for X-ray, and this was also the case for large private hospitals, such as Diaconessenhuis, Petronella and Modjowarno.

34 Indisch Verslag 1938, E. Gezondheidszorg, 10. Pharmaceutische aangelegenheden, 401(NI Report 1938, Health Care, Pharmaceutical Affairs).

35 Staat betreffende de formatie van het aan Gouvernements burgerlijke ziekeninrichtingen verbonden personeel, bedoeld bij artikel 12 van de Regelen betreffende de bestemming van Gouvernements burgerlijke ziekeninrichtingen, de formatie van het personeel zoomede de kosten van verpleging in die inrichtingen, vastgesteld bij besluit van het wd. Hoofd van den Dienst der Volksgezondheid van 30 Augustus 1927 no. 16553 Supplement Staatsblad van Nederlandsch-Indië 1927, no. 11446). Transl.: Survey of GCH personnel, their numbers and the tariffs for public hospitals , as published by the acting Chief of the Public Health Service.

36 In 1929 a number of 179 laboratoriumhelpers were licensed by these hospitals. The Medical Laboratory at Batavia trained 11 students in the same year. The latter training differentiated between chemical and bacteriological analysts.

37 A.P. Ketel, 1894-1934 veertig jaren Medische Zending Zendingsziekenhuis te Modjowarno.

38 Gemeente Ziekenhuis te Bandoeng (Leaflet at the opening in August 1923). 


\section{Hospital Personnel}

From 1910 to 1930, the number of hospital workers increased by some $150 \%$ (from 1,346 to 3,538, see Figure 15). The largest growth occurred for nursing personnel. In addition, considerable effort was made to invest in training facilities for auxiliary health care professions. It was mentioned that the Medical Faculty began to deliver fully licensed doctors. All these efforts resulted in more and better qualified personnel for the hospitals in the 1930s.

From 1930, a regular flow of newly trained nursing personnel became available for existing hospitals. The difference between the old and new situation may be seen in one of the largest hospitals of the Netherlands Indies, the Central Civil hospital (CBZ) of Batavia. Before 1900, the average nurse: patient ratio had been 1:20 and for a capacity of 650 beds some 30 male or female attendants were available. ${ }^{39}$ These attendants had no training whatsoever and received only a salary of $f 120$ per year. From 1912, the function mantri-nurse was introduced by the Civil Medical Service (salary range from $f 300$ to $f 600$ ). ${ }^{40}$ The nurse: patient ratio was still 1:20. By the end of the 1920s the average ratio had become 1:3 and the ratio qualified to unskilled nursing personnel became two unskilled attendants per qualified nurse. ${ }^{41}$ As the CBZ at Batavia had a capacity of 1,000 beds with an average occupancy of $72 \%$ in the 1930 s, the nursing personnel will have been about 240 , of whom 160 were untrained. ${ }^{42}$

In 1938, the Protestant missionary hospitals together employed 90 doctors and almost 2,300 mantri nurses. ${ }^{43}$

According to a table, published by the Head of the Public Health Service, the personnel required for an average rural hospital of 100 beds, would consist of one doctor, two nurses, 10 mantri-nurses, 16 pupils or uncertified nurses, two administrative workers, four personnel for housekeeping (cook, linen, etc.) and 10 unskilled workers. ${ }^{44}$

How was the situation in the field of personnel and training in the other three colonial situations: in the Philippines, British India and French Indochina?

Starting with the Philippines: The fresh colonial authorities were keen on demonstrating their zeal for civilizing the colonized population by sending 1,000 American teachers to educate children and create an infrastructure for Philippine teaching facilities. Contrasting with the educational system of the Netherlands Indies, Philippine education was public, universal and free. Although there had been an early opportunity for Filipino medical

39 Staatsblad van Nederlandsch-Indië 1879, no. 18 en 1908, no. 64 (NI Statutebook 1879, no. 18 and 1908, no. 64).

40 Staatsblad van Nederlandsch-Indië 1912, no. 87 (NI Statutebook 1912, no. 87).

41 Bijblad van het Staatsblad van Nederlandsch-Indië 1927, no. 11446 (Supplement NI Statutebook 1927, no. 11446).

42 In 1938, the CBZ Batavia employed 29 European nurses, 15 European pharmacy assistants, 13 European analysts, 12 European doctors, 8 indigenous doctors

43 Peverelli, De zorg voor de Volksgezondheid in NI, 88-91.The Protestant missions exploited 31 central hospitals, 70 auxiliary hospitals and 237 outpatient clinics.

44 Table belonging to Decision of Head DVG no. 16553 of $30^{\text {th }}$ August 1927 (NI Statutebook no.11446). 
doctors to graduate at the University of Santo Tomás, the Americans did not continue the Spanish health system, including its training facilities. Nevertheless, by 1940, there were 4,909 licensed physicians in the Philippines, equalling 3.1 per 10,000 of population, whereas the Netherlands Indies only counted 0.22 per 10,000 and the United States about 10 per 10,000. About $90 \%$ of these physicians were Filipinos and a great majority were graduates of local medical colleges. ${ }^{45}$ In the auxiliary medical professions, the interim military board of health for Manila organized a corps of carefully supervised vaccinators. The training of nurses was succesful and led to a large body of the profession, so much so that after the relaxation of American Immigration criteria in the 1960s, by the end of the 20th century the American nursing care had become markedly Filipinized.

This was contrasted by the training facilities in French Indochina. The training of nurses and midwives suffered from language and curriculum problems, such as were witnessed at the start of the midwife training in NI. Ultimately, new opportunities were sought for the midwife training and among others efforts were made to re-educate the traditional birth attendants (the $\mathrm{Ba} \mathrm{Mu}$ ). These efforts were succesful and resulted in some 400 midwives by 1939 and 600 posts of $B a M u$. The training of indigenous doctors suffered from the favourable position of the military doctors. The graduates of the medical school at Hanoi had to follow a traineeship of two years before being licensed and then they had to accomplish an additional two years of service before entering the competition for superior ranks. By the end of the 1930s the total number of European physicians in French Indochina was 157 , whereas there were 245 Indochinese physicians, together resulting in the ratio 0.16 per 10,000 of population.

For British India the recruitment of medical personnel, nurses and midwives was hampered by religious obstacles. Some training facilities were only available for the Brahmin class. Members of the Bengali population could receive a training to become a hospital assistant. But the medical profession in India was not regulated by a Medical Registration Act and so the doctor's title was not protected. Harrison mentions 'that failed medical students and tradesmen seeking to supplement their income were thought to constitute the bulk of those claiming to be doctors. ${ }^{36}$ The Subordinate Medical Service organized a 2-year course of instruction and an apprenticeship at a recognized medical institution for assistant surgeons (Europeans) and hospital assistants (Indians). In 1940, there were 14,000 medical graduates and 27,000 medical licentiates, or a total of 41,000 physicians practicing in India. This means a ratio of 1.17 on 10,000 of population, compared to a ratio of only 0.22 per 10,000 for the Netherlands Indies. ${ }^{47}$

\footnotetext{
45 James Stevens Simmons, Global Epidemiology, a Geography of Diaease and Sanitation (London 1944) 91-92.

46 Harrison, Public Health in British India, 17.

47 Simmons, Global Epidemiology, 115-116.
} 
As for the training of nurses, several initiatives were started, but for a large period only Christian girls applied for a nursing career. The Hindus looked with great disfavour upon nursing and would not allow their women to join these ranks. In the course of the first half of the twentieth century Hindu girls of good education began to enter the nursing profession, but the number of Mohammedan candidates was still almost negligible by the end of the 1930s. As for the midwives: the same problem as in the NI occurred: the great majority of confinements in India were conducted by indigenous dhais (in the NI doekoen baji). They had been presiding over childbirth for ages and the profession passed from mother to daughter, it was hereditary. The health authorities looked for unorthodox solutions and organized two training courses for midwives: one for the cities and one for the rural areas, whereas the dhais should be registered and get an elementary practical training for at least 6 months. Eventually this led to 724 trained dhais employed by maternity centres and to 1,617 fully trained midwives.

For British Malay (Federated and Unfederated States and Straits Settlements) the list of medical practitioners published by the Medical registration Ordinance in March 1939 listed 767 physicians as then living in the Malay States and having licenses to practice medicine in the Straits Settlements and the Malay States. It was estimated that there were approximately 1.4 physicians per 10,000 of population. The Malayan Nursing Service was composed of English nurses and in 1937 had 176 members. In local nursing services there were 162 staff nurses, 56 public health nurses and 367 student nurses. The total number of nurses in the Malayan health department, including the student nurses, was $761 .^{48}$

Concluding, most striking is the low ratio of doctors in both, the Netherlands Indies and in French Indochina (0.22 and 0.16 per 10,000 of population), compared to British India, Malaysia and the Philippines, which scored in that order 1.17, 1.4 and 3.1 per 10,000 of population.

\section{Hospital Finances}

Before 1930, the NI Government had issued regulations to subsidize private indigenous hospitals and auxiliary hospitals. In 1936, new regulations were issued that responded to the new position of zelfstandige gemeenschappen on Java (autonomous communities) such as cities, regencies and provinces. ${ }^{49}$ In 1937 similar regulations were announced for the Outer provinces Sumatra, Borneo and the Great East (Celebes, Moluccas and other islands), which had an appointed Governor and autonomous groups of communities with elected

\footnotetext{
48 Simmons, Global Epidemiology, 163-165.

49 Staatsblad van Nederlandsch-Indië 1936, no. 582, "Decentralisatie, gedeeltelijke overdracht van de landszorg voor de volksgezondheid op zelfstandige gemeenschappen" (Decentralization, transfer of national health care duties to autonomous communities, NI Statutebook 1936, no. 582).
} 
councils instead of Residencies. ${ }^{50}$ Both regulations of 1936 and 1937 had been issued by the Governor-General A.W.L. Tjarda van Starkenborgh (1936-1945). Previously, the financing of operating expenditure in public hospitals had been straightforward: these hospitals had all deficits reimbursed by the Treasury. This continued to be the case for the central government hospitals and the facilities for psychiatric patients, but the decentralized hospitals had to submit their financial requirements to the councils of autonomous communities, cities, regencies and provinces and request to be included in the budgets of these councils. In 1930, when 77 (46 for Java and 31 for the Outer Provinces) government civil hospitals (GBZs) still fell under the budget of J. van Lonkhuijzen, Head of the Public Health Service, an amount of $f 1.4$ million had been voted for these 77 hospitals and $f 2.4$ million for the three central government hospitals. In 1938, the Public Health Service budget for hospitals had been diminished to $f 2.8$ million. Further decentralization during the 1930s was accompanied by a new flow of cash transfers. In this way the budgets for decentralized administration and autonomous indigenous administrations increased from $f 26.4$ million (in 1933) to $f 45$ million (budget 1940). ${ }^{51}$

As for the expenditure of individual hospitals, these amounts varied greatly, as might be deduced from the two examples just mentioned: the three central government hospitals had $f 800,000$ on average, while the 77 GBZs had less than $f 20,000$ per hospital per annum. For the central missionary hospitals and the European hospitals, the annual budgets could vary, depending on the number of patients. In 1933, the medical director of the Modjowarno mission hospital, A.P. Ketel, reported for his hospital a total expenditure of almost $f 112,000$. The average number of occupied beds for that year was 284 (hospital capacity: 300 beds). For the Deaconess hospital at Batavia the annual budget of 1932 had been reduced to $f 176,000$ for an average of 57 inpatients. The different character of both hospitals is shown by the difference in average costs per inpatient day: $f 1.08$ for Modjowarno and $f 8.45$ for the Deaconess Hospital. The 1933 annual account for the Modjowarno hospital may illustrate the different components of hospital expenditure (see Table 16). It appears that the income from patient billing was not very significant. The Javanese population contributed only $30 \%$ of the total inpatient income of $f 9,407$, which was in itself only 8 $\%$ of total income. The European and Chinese patients contributed about $58 \%$ of the item Inpatient bills, and companies paid the remaining part. ${ }^{52}$ The financial reports of the

50 Staatsblad van Nederlandsch-Indië 1937, no. 464, "Decentralisatie Buitengewesten, organieke regeling voor op den voet van het tweede lid van artikel 123 der Indische Staatsregeling aangewezen gedeelten van nieuwe gewesten behoorende tot het rechtstreeks bestuurd gebied der Buitengewesten en niet tot het gebied van een stad" ("Groepsgemeenschapsordonnantie"). NI Statutebook 1937, no. 464, Decentralization Outer Provinces.

51 Begrooting van Nederlandsch-Indië voor het dienstjaar 1940, Bijlage A van de Memorie van Toelichting, 47. (Budget NI for 1940, Annex A Explanatory memorandum).

52 1894-1934, Veertig jaren Medische Zending, Zendingsziekenhuis te Modjowarno (40 year medical mission Modjowarno) 60-61. 


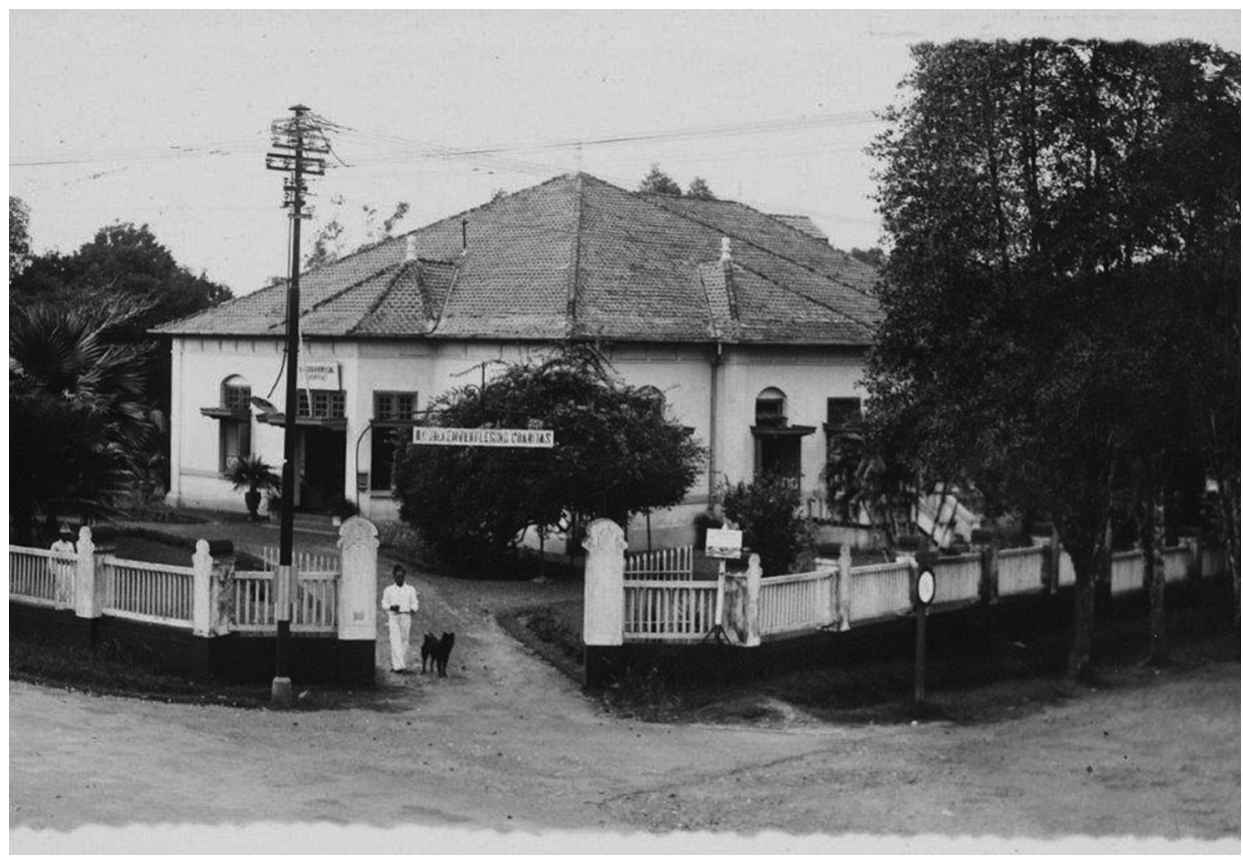

Figure 31 Roman Catholic hospital Palembang (Source: KITLV)

Diaconessenhuis at Batavia showed a quite different picture. ${ }^{53}$ In some years the nursing fee covered not less than $75 \%$ of all expenditure. However, compared to the majority of hospitals the financial situation of the Diaconessenhuis was exceptional. Its largest group of patients was European. The nursing department On- en Minvermogenden admitted a total of 128 patients in 1930 , compared to 1,748 patients for the paying departments.

Table 16 Annual account 1933 Modjowarno (summarized)

\begin{tabular}{lclc}
\hline \multicolumn{1}{c}{ Expenditure $($ in $\boldsymbol{f})$} & \multicolumn{2}{c}{ Income $($ in $\boldsymbol{f})$} \\
\hline Salaries & 50,934 & Subsidy & 82,644 \\
Medicines \& instruments & 15,627 & Grants & 17,612 \\
Food and housekeeping & 18,297 & Inpatient bills & 9,407 \\
Electricity, telephone & 8,948 & Neosalvarsan & 1,670 \\
Maintenance \& transport & 15,808 & Other & 526 \\
Positive balance & 2,245 & & $\mathbf{1 1 1 , 8 5 9}$
\end{tabular}

53 Gedenkboek 40 jaar ziekenverpleging 1895-1935 (Memorial volume 40 year nursing of the Queen Emma Hospital at Weltevreden (Batavia 1936) 36-37. 
H. Zeydner, Chairman of the Association that exploited the much smaller Deaconess Hospital of Soerabaja, sketches a similar picture for the annual account 1939 of his hospital. The total expenditure of $f 112,000$ had been made for an average bed occupancy of 36 patients. In-patient income covered almost $80 \%$ of the expenditure $(f 89,000)$. No category on-, en minvermogenden was stated and only patients for $1^{\text {st }}, 2^{\text {nd }}$ and $3^{\text {rd }}$ class nursing had been admitted. ${ }^{54}$ Inspecting the third category of private hospitals, company hospitals, it is obvious that in this case, in which almost all patients were poor coolies, hardly any financial contribution could be expected.

In view of the overall picture with very few paying patients, the founding of ziekenfondsen (health insurance companies) took place hesitantly. Nevertheless, there were some funds such as the Ziekenfonds Buitenzorg ${ }^{55}$, founded as early as 1906, but they mainly provided for the costs of medicines and bandages, beside funeral costs. For many years the reports about health care in the Koloniale Verslagen carried the heading Ziekengestichten en fondsen (Hospitals and health insurance funds), but the latter category seldom received any comment.

\section{Private hospitals 1930-1942}

The two components of the category private hospitals, the charity hospitals and the company hospitals, experienced the largest growth from 1910 to 1930. During that period the company hospitals grew in number almost tenfold and the charity hospitals grew by more than $200 \%$ (See table 10). From 1930, this strong development was blocked by the economic depression. Occasionally, some new charity hospitals were founded, especially Roman Catholic missionary hospitals. A number of company hospitals closed in the same period for financial reasons. ${ }^{56}$ Still, near the end of the 1920s, a new development took place on Java, as the sugar industry took some initiatives to start company hospitals.

\section{Missionary hospitals}

In the previous Chapter it was explained that the category subsidized private hospitals existed of four sub-groups: In 1930, the largest group was formed by the Protestant and Roman Catholic missionary hospitals (together 57), a second far smaller group was formed by the so-called Deaconess hospitals (4), the third group was formed by the hospitals of the Salvation Army (2 general hospitals and 7 specialized facilities) and a large remaining group of 26 diverse organizations completed the picture. Whereas the

\footnotetext{
54 Verploegh Chassé, W., 43e Jaarverslag Soerabajasche Ziekenverpleging (Soerabaja 1940). Transl.: $43^{\text {rd }}$ annual report on Soerabaja nursing.

55 By Government Decision of 20 November 1906 no. 40 the Ziekenfonds Buitenzorg was licensed to acquire medicine and bandage materials from the military pharmacy at Buitenzorg.

56 The leaving Governor of Sumatra Eastcoast, B.C.C.M.M. van Suchtelen mentions in his Memorie van Overgave a reduction to 30 hospitals, whereas 47 had been mentioned by Kouwenaar for the year 1930 .
} 
Protestant missionary hospitals experienced their main development in the two preceding periods (1890-1930), the Roman Catholic missionary work occurred during the interbellum period, 1918-1940. ${ }^{57}$ After 1935, a change in the Vatican missionary policy created new opportunities for sisters of mission congregations: they were allowed to become female medical doctors and midwives. ${ }^{58}$

In 1938, the first 3 Dutch Roman Catholic female mission doctors received their medical degree. According to Willemsen this Roman Catholic instruction facilitated the expansion and success of the Roman Catholic medical mission work after World War II (See Figure 31). In 1940, there were 126 missionary hospitals, 116 general hospitals and 10 specialized hospitals. ${ }^{59}$ Despite the economic situation in the 1930s, 26 new hospitals were established in these years. Most of these hospitals were accounted for by Roman Catholic congregations. The regional distribution picture of general missionary hospitals was as follows (see Table 17).

Table 17 Regional distribution general missionary hospitals 1940

\begin{tabular}{lccc}
\hline Island & Protestant & Catholic & Total \\
\hline Java & 52 & 16 & 68 \\
Sumatra & 21 & 4 & 25 \\
Borneo & 0 & 7 & 7 \\
Celebes & 11 & 5 & 16 \\
Moluccas & 1 & 4 & 5 \\
Other islands & 4 & 1 & 5 \\
\hline Total & $\mathbf{7 9}$ & $\mathbf{3 7}$ & $\mathbf{1 1 6}$
\end{tabular}

\section{Company hospitals}

In Chapter 5 the enormous expansion of company hospitals was described. The largest number of these hospitals was found on Sumatra, almost half of the total reported for the year 1930. On Java, the second half of the 1920s witnessed initiatives of the Sugar Industry. In previous Chapters attention was paid to the situation in the Eastern part of Sumatra in the plantation belt, where many experiments were initiated to improve the health condition of the coolies. The first Coolie Ordinance of 1880 was designed to protect the coolies, but most tobacco and rubber estates benefited from the severe regime it laid on the lives of the Chinese, Indian and Javanese workers. They were more or less condemned to serve out their

57 A. Camps, V. Poels and J. Willemsen, Dutch Missionary Activities, an oral history project (Nijmegen 2005$) 36$.

58 Jan Willemsen, Van tentoonstelling tot wereldorganisatie,1925-1995 (Nijmegen 1996) 93-105.The instruction invited religious sisters to become engaged in professional medical mission work.

59 See database online www.colonialhospitals.com 
long term labour contracts or had to face the punitive measures of the "poenale sanctie". This sanction was abandoned by the tobacco cultivators, because tobacco obtained from indentured labour was banned in the USA, one of the important importers of the Sumatra tobacco. ${ }^{60}$ The "poenale sanctie" was abolished in the Koelieordonnantie of $1931 .{ }^{61}$ Until that time, the strict regime had enabled the company physicians to have all workers recorded, from the moment they set foot on Sumatran soil to the end of their contracts. This allowed some of the medical staff to embark on profound research projects while studying the many diseases the coolies took with them from abroad or incurred during their stay on the East Coast. W.A.P Schüffner and W.A. Kuenen, two researchers, became famous and were appointed as professors of tropical hygiene in Amsterdam and Leiden. ${ }^{62}$ Tropical medicine benefitted greatly from their experience and research.

This development should not distract the attention from other areas and initiatives in both the field of health care and in the establishment of hospitals. The sugar belt on Java, mainly in the Central and Eastern parts of that island offered an interesting test-case for the achievements of direct health care. The agricultural companies in the central parts of Java welcomed the way in which missionary societies took initiatives in the field of health care. Especially the establishment of a network of outpatient clinics and auxiliary hospitals under guidance of an experienced nurse and supervised by a visiting doctor earned their support. They witnessed these initiatives in the region of Djokjakarta (Petronella Hospital) and offered financial support (see Figure 32).

As the company hospitals had their own methods of reporting, sometimes annually, sometimes at the occasion of jubilees, it is not easy to follow and be sure how many new company hospitals were established during the 1930s and how many were closed. As for the sugar industry during the crisis years, a number of them did not survive and certainly this sector witnessed considerable contraction. But in some other industries and other regions there were no problems. By 1940, the total number of company hospitals had decreased from 301 to 238 with a capacity of 20,076 beds. Apart from that, 53 hospitals had been offered a contract by the Public Health Service to place 6,235 extra beds at its disposal. ${ }^{63}$ An example of this contracting was the way in which the Plantershospitaal of the Serdang Doctor Fund took care of the hospital admission of poor persons entitled to receive hospital

60 A.L. Stoler, Capitalism and Confrontation in Sumatra's Plantation Belt, 1870-1979 (New Haven 1985) 21, mentions that during the 1920s and 1930s almost half (45\%) of the East Coast exports were destined for the United States.

61 Koelieordonnantie of 1931 (Staatsblad van Nederlandsch-Indie 1931, no. 94).

62 Willem August Paul Schüffner (1867-1949), physician at the Senembah Company, was appointed professor of tropical hygiene at Amsterdam in 1923. His assistant, Willem Abraham Kuenen (1873-1951) was appointed at Leiden in 1924.

63 E. Kits van Waveren, “De artsenpositie in Indonesië” Ned Tijdschr Geneeskd. 91 (1947) 3445. 


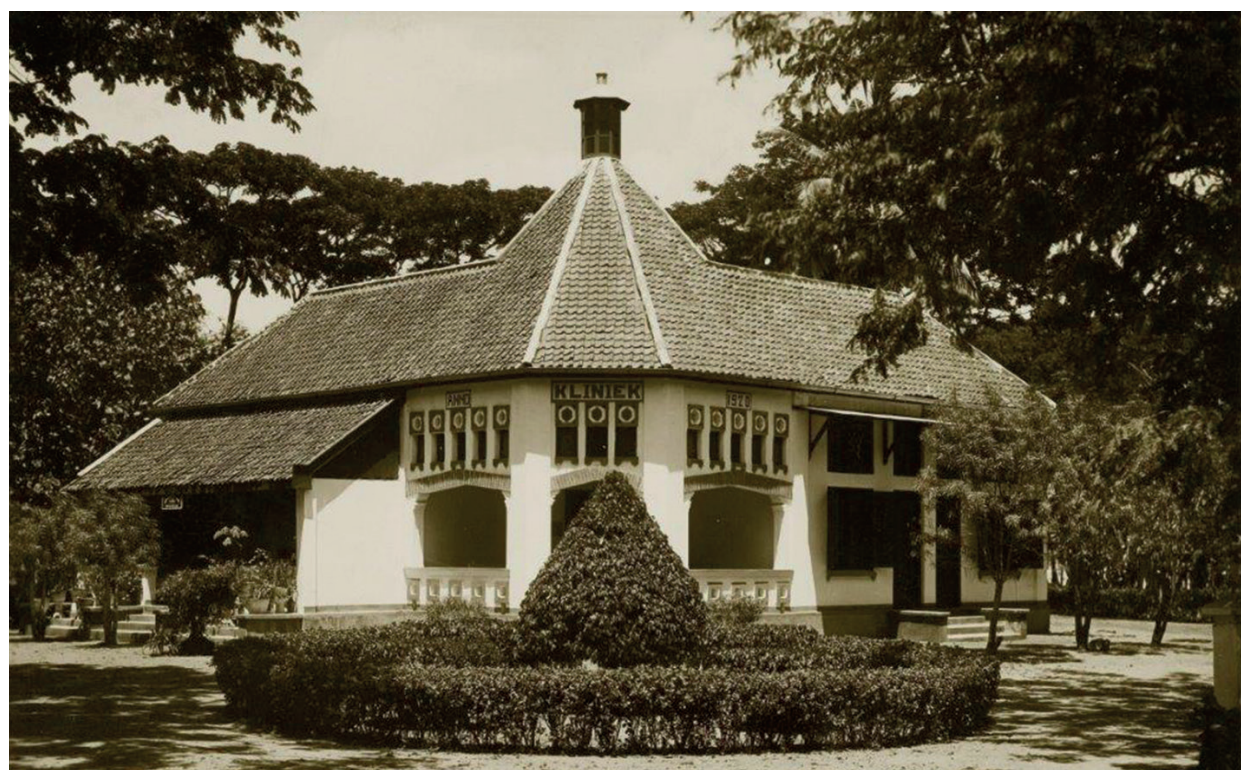

Figure 32 Clinic Sugar Company Ngandjoek (1930) (Source: KITLV)

care. The Government reimbursed $f 0.65$ a day for these patients. ${ }^{64}$ In Chapter 5 three ways were discussed by which the Civil Medical Service involved third parties in the upkeep of hospitals. ${ }^{65}$ The most common way was a notarial agreement by which a hospital association took over a government hospital by paying rent and by accepting responsibility for the care of all patients sent by the government.

\section{Specialized hospitals}

Before 1930, the specialized hospitals comprised more than 70 institutions. For some categories this was about the highest level they reached before 1942. This was the case for psychiatry: 4 psychiatric hospitals, 4 passage houses and 6 nursing homes. For leprosy, tuberculosis and eye diseases some new developments took place. Altogether, almost 100 specialized hospitals were recorded in 1940. This suggests that during the years of economic crisis about 30 new hospitals appeared, equalling a $40 \%$ increase. The efforts of civilians,

64 Bijblad Staatsblad van Nederlandsch-Indië 1934, no. 13160 "Regeling van de opneming van behoeftige Gouvernementsonderhoorigen, gevangenen of vanwege de politie en justitie aangebrachte personen, alsmede verdere rechthebbenden op vrije genees- en verloskundige Gouvernementshulp in het door de Serdang Cultuur Maatschappij beheerde Plantershospitaal te Perbaoengan, Oostkust van Sumatra)". Transl.: Regulation to admit poor persons, entitled to hospital care to the Plantershospitaal of the Serdang Culture Company (Supplement NI Statutebook 1934, no.13160).

65 Bijblad Staatsblad van Nederlandsch-Indië Indisch 1921, no. 9786 "Notarieele overeenkomsten met rechtspersonen inzake ziekenhuisbehandeling. Modelcontracten.” Transl.: Agreements with third parties to arrange for hospital treatment (Supplement NI Statutebook 1921, no. 9786). 
mainly Europeans, organized in the 3 main associations for specialized treatment (leprosy, eye diseases and tuberculosis) may explain in part these achievements.

From the second half of the 1930s, the financial situation of the Netherlands Indies and the homeland improved so much that new funds were created to stimulate health care facilities. The 1938 NI budget allowed for an additional $f 1.8$ million for the Public Health Service, whereas The Netherlands voted $f$ 1,580,000 from the Dutch Welvaarts bijdrage (Prosperity allowance). As prosperity increased most in the so-called Rubbergebieden (Rubber areas) a percentage of the export duties was set aside in the Rubberfonds to finance urgent needs of the NI population. ${ }^{66}$ Specialized hospitals were among the beneficiaries of this Fund.

\section{Leprosy institutions}

In the 1930s, the Vereeniging tot bestrijding van lepra (Association to combat leprosy) concentrated its activities on combating unhygienic conditions of life and on tracing commencing cases of leprosy and subsequently isolate and treat them. Peverelli describes the new approach: The Binnenlands Bestuur and especially the heads of desas were mobilized to identify the suspected patients, who were examined and recorded together with their household and family. In some districts, research stations were established a maximum of $3 \mathrm{~km}$ from each other. These stations collected data for the different desas. After finishing the exploration, the stations were converted into treatment stations, where patients received their injections weekly and if necessary were bandaged. ${ }^{67}$ The aim was to promote the voluntary registration of leprosy and isolation in separate huts on the premises of the patient. In some parts of the archipelago, this policy was well adopted, but the chief of the Public Health Service reported about Ambon in 1939, that the population still strongly disavowed this policy. ${ }^{68}$ The same report mentions that for the year 1937 in the whole archipelago, 8,089 leprosy patients had been recorded, of whom almost a quarter $(1,921)$ on Bali and Lombok and only 385 in the Moluccas.

In the course of the 1930s each desa on Bali and Lombok had its own leprosy-committee to report patients and isolate them. In 1940, a number of 54 leprosy institutions could be found in the entire archipelago. Two of these institutions were run by the government ( 369 beds), 28 were managed by native states ( 1,050 beds) and 24 by private organizations ( 3,032 beds). ${ }^{69}$ On 25 November 1935, Dame A.C. de Jonge, née baroness van Wassenaer, wife of the Governor-General and patroness of the new institute, opened the Queen Wilhelmina Institute of Leprosy Research at Batavia, financed by the Queen Wilhelmina Jubileum

66 The Rubberfonds was created by Law of 2 April 1937 (Nederlands Staatsblad 901).

67 Peverelli, 78-79. The author mentions the use of iodated aethylester of the chaulmoogra oil in juvenile cases and commencing cases. See also: C.D. de Langen, "Hoge doses Chaulmogra-Ester bij de behandeling van lepra", GTNI 78 (1938) 682-683.

68 Mededeelingen Dienst Volksgezondheid, XXVIII (1939) 2-3: 57-136. Transl.: Survey Public Health Service.

69 Survey Public Health Service 1940, as cited by Kits van Waveren, 3445. 
Foundation. The director of this institute, P.H.J. Lampe, former Head of the Public Health Service of Suriname, announced that his institute would organize an annual meeting called Lepradag, during which the results of research on leprosy would be presented. ${ }^{70}$

\section{Eye Hospitals}

Before 1930, eight eye hospitals had been established under the auspices of the Vereeniging tot verbetering van het lot der blinden in NI (Association to improve life conditions of blind people). The crown jewel of eye care remained the Queen Wilhelmina Eye Hospital, which celebrated its $25^{\text {th }}$ anniversary in 1934, when G. Fast was its medical director. In 1938, the hospital shifted from a government status to a provincial one as a consequence of the decentralization policy. In the meantime, the capacity of the hospital had increased to 176 beds, which had an occupancy rate of $75 \%$ and counted 48,180 nursing days in 1938.

The Public Health Service opened centres with an eye doctor and a specialized nurse for some regions. These activities were a response to reports of very high trachoma (>50 \% of all children) prevalence at schools on the North Coast of Java. Trachoma mantris visited kampongs, recorded cases and lectured about hygiene and prevention of diseases.

From 1930, new eye clinics were started and new initiatives were set up to combat eye diseases. The ophthalmologist J. Tijssen started an eye clinic at Meulaboh (Atjeh) in 1932. In 1937, the same doctor Tijssen embarked on an expedition in Kediri (East Java) to perform trachoma operations. He managed to perform 1,860 operations in 111 days on 1,084 patients. ${ }^{71}$ A Protestant mission started an eye clinic at Krawang (West Java) in 1938. Twice a month, the head registrar of ophthalmology of the CBZ at Batavia arrived to accomplish the main eye surgery in this clinic. Prevention of trachoma had a high priority in the Batavia residency. Specially trained mantri nurses charged with treating trachoma were assigned to different towns in the Batavia regency. ${ }^{72}$ The private eye doctor Greve performed surgery in a number of Landschap (District) hospitals on the East Coast of Sumatra. At Medan this doctor started a small eye clinic that was expanded with the help of the Rubber Fund in $1937 .{ }^{73}$ By 1940 , about 25 eye specialists could be found in the entire archipelago and eleven eye clinics were operating, nine of them on Java and two on Sumatra. ${ }^{74}$

\section{Sanatoria for tuberculosis}

The Central Association against Tuberculosis at Batavia was subsidized by the NI government. This financial assistance was available to stimulate new activities, such as TB

\footnotetext{
C. Bonne, "Het Koningin Wilhelmina Instituut voor Lepraonderzoek”, GTNI 75 (1935) 2010.

Peverelli, De zorg voor de volksgezondheid in NI,74.

Indisch Verslag 1938, Gezondheidszorg, 389.

Memorie van Overgave of Governor B.C.C.M.M. van Suchtelen (1936) of Sumatra Eastcoast, 198.

74 A.W. Mulock Houwer, "De bestrijding der blindheid in Nederlandsch-Indië, in het bijzonder op Java", GTNI 80 (1940) 2007. Transl.: The combat against blindness in NI, especially on Java.
} 
prevention clinics and the building of sanatoria. Subsidies were granted up to $75 \%$ of the investment costs and $75 \%$ of the budgetary deficits. Before 1930, the Association had established a number of consultatiebureaus (TB prevention clinics) and sanatoria. ${ }^{75}$

Nevertheless, the prevalence of tuberculosis increased and several reports made clear that tuberculosis had become endemic. From the second half of the 1930s, additional funds were available to cope with this matter. Some years before, new initiatives were taken in the Outer Provinces and the capacity of existing sanatoria on Java was enlarged. Beside the start of new facilities, innovations were introduced in the diagnosis and treatment of tuberculosis (x-ray, operations, Mantoux tests).

In November 1934, a TB prevention clinic was opened in the Municipal Hospital at Medan. From 1935, this initiative was followed by similar TB prevention centres on Sumatra at Bindjei, Tandjong Poera, Tebing Tinggi, Tandjong Balei and Pematang Siantar. All these centres were initiated by a sister organization, the Association to combat Tuberculosis on the East Coast of Sumatra. In 1932, a private sanatorium was established by the plantation physician of Perbaoengan, O. Paneth in Kaban Djahé. ${ }^{76}$ On Celebes, the Minahassa Jubileum Stichting financed a sanatorium at Noongan with 60 beds. It was opened on 1 October $1934 .^{77}$ In the next years a number of new sanatoria were established on Java: the sanatorium Zeerust on the island Onrust near Batavia (opened on 29 September 1935), the sanatorium Wonosalam near Modjowarno, established by the mission hospital. It started with 70 beds, only for male patients. A so-called volkssanatorium (native sanatorium) was opened at Pakem (Central Java) on 30 September 1938. At Songgoriti (East Java) a sanatorium was opened on 1 October $1938 .^{78}$ At Medan (Sumatra), the Queen Emma clinic for tuberculosis patients was opened on 1 January 1938. This clinic was largely financed by the so-called Rubbergelden. ${ }^{79}$

The 1937 Public Health Service report mentions investigations at schools, which demonstrated that in the western part of Java tuberculosis had meanwhile become endemic. In the municipality Cheribon, between $24 \%$ to $76 \%$ of the school youth had a positive Mantoux-reaction. Corresponding data could be collected at Bandoeng and at Semarang. $22 \%$ of the reported sick leave of indigenous civil servants was due to tuberculosis.

75 The main function of the consultatiebureaus was to start programs to inform the population, to diagnose tuberculosis and to provide assistance to patients. Tuberculosis patients were occasionally admitted to general hospitals, but the severe cases were treated in sanatoria. By 1930, a number of 3 sanatoria had been established on Java, at Batoe (East Java), at Patjet and Tjisaroea (both West Java) and 2 on Sumatra, the former health centre at Bandar Baroe of the Amsterdam-Deli Company and the sanatorium at Brastagi, established by the Senembah Company in 1922.

76 B.M. van Driel, "De Sociale Geneeskunde in den Delischen Kring”, GTNI 76 (1936) 308.

77 Memoires Governor-General B.C.de Jonge: the sanatorium was called Queen Emma Sanatorium and was financed from the Jubilee donation on the occasion of the 250-year association of the VOC and the Minahassa. In the Netherlands a large amount of money was collected to donate a Tuberculosis sanatorium for the Minahassa population.

78 Indisch Verslag 1938, Chapter Gezondheidszorg, 388.

79 Begrooting van Nederlandsch-Indië voor het dienstjaar 1938, Bijlage A. van de Memorie van Toelichting: Taxes on indigenous rubber exportations provided funds to finance health care measures. An amount, totalling $f 400,000$ was available in the period 1936-1938 for building TB sanatoriums. 
In the NI, X-ray facilities were used for diagnosis purposes, though not all the centres had these facilities. District offices for public health opened at Tapanoeli (with X-ray facility), at Medan (X-ray apparatus granted by the Sultan of Deli), at Bandjermasin and at Pontianak (X-ray received from the Vereeniging). Bandjermasin and Pontianak are situated on the island of Borneo. In the Minahasa (northern part of Celebes) eight district offices functioned with a public nurse or someone to pay home visits. A new sanatorium was opened at Ngawen (Central Java) and in the regency of Grobogan plans were drawn up to establish a sanatorium. The capacity of the sanatorium at Pakem was enlarged to 94 beds. During $1937,8,495$ patients suffering from tuberculosis were treated in the government hospitals. Of these patients 1,746 died.

By 1940 the number of sanatoria was 17 with 1,384 beds. Only five of these institutions were run by the government ( 254 beds), 12 were managed by private organizations $(1,130$ beds), of which 7 (760 beds) were subsidized and 1 had a contract with the Public Health Service (120 beds). ${ }^{80}$

\begin{tabular}{ll} 
The regional distribution of the sanatoria was in $\mathbf{1 9 4 0}$ \\
\hline Java West & 6 sanatoria $^{1}$ \\
Java Central & 3 sanatoria (Pakem, Ngawen, Getasan) \\
Java East & 3 sanatoria (Wonosalem, Batoe, Songgoriti) \\
Sumatra & 4 sanatoria (Bandar Baroe, Brastagi, Medan, Kabandjahe) \\
Celebes & 1 sanatorium (Noongan) \\
\hline
\end{tabular}

${ }^{1}$ Soekaboemi, Ngamplang, Krawang, Onrust, Tjisaroea and Patjet.

\section{BALANCE}

A lot of changes marked this period. First of all, the rather rigorous decentralization from 1937 left only two civil hospitals (GBZ) under government control, while all the others were transferred to local, regional or provincial administrations. With respect to private initiative, two opposite tendencies can be discerned. Some company hospitals, with the exception of oil companies, were closed because of the economic depression. By contrast, the number of Roman Catholic hospitals experienced a continued growth and so did the sanatoria. The result was a continued increase in hospitals with more specialized hospitals and more missionary hospitals despite the economic crisis.

It is time to make a balance of the situation around 1940 by evaluating hospital availability and accessibility around that year (see tables 18 and 19). Table 18 presents the distribution of hospitals, whereas table 19 presents the distribution of hospital capacity. Both Tables 
apply to Java and to the different Outer Provinces. Earlier (about 1890), it was demonstrated that most hospitals were established on the island of Java, 51 hospitals with 3,700 beds for civilians. The Outer Provinces experienced considerable arrears with only 28 hospitals and 600 beds.

Table 18 Distribution of NI hospitals $1940^{81}$

\begin{tabular}{|c|c|c|c|c|c|c|c|}
\hline \multirow[t]{2}{*}{ Region } & \multirow[t]{2}{*}{ Public } & Priva & Iospitals & \multirow[t]{2}{*}{$\begin{array}{l}\text { Subtotal } \\
\text { general } \\
\text { hospitals }\end{array}$} & \multirow[t]{2}{*}{$\begin{array}{l}\text { Specialized } \\
\text { Hospitals }\end{array}$} & \multirow[t]{2}{*}{ Military } & \multirow[t]{2}{*}{$\begin{array}{l}\text { Total } \\
\text { hospitals }\end{array}$} \\
\hline & & Subsid. & Non-subs. & & & & \\
\hline Java \& Madoera & 48 & 60 & 78 & 186 & 24 & 20 & 230 \\
\hline Sumatra & 16 & 22 & 87 & 125 & 28 & 33 & 186 \\
\hline Borneo & 4 & 3 & 36 & 43 & 4 & 10 & 57 \\
\hline Celebes & 4 & 7 & 47 & 58 & 11 & 5 & 74 \\
\hline Moluccas & 2 & 3 & 30 & 35 & 5 & 4 & 44 \\
\hline Other Islands & 6 & 1 & 18 & 25 & 10 & 7 & 42 \\
\hline Outer Provinces & 32 & 36 & 218 & 286 & 58 & 59 & 403 \\
\hline Java \& Outer Prov. & 80 & 96 & 296 & 472 & 82 & 79 & 633 \\
\hline
\end{tabular}

Source: Indisch Verslag 1938, Ziekeninrichtingen, 73-74.

Looking at the figures in Table 18, only two categories of hospitals (public and subsidized private hospitals) on Java still outnumbered those of the Outer Provinces (108 by 68). The other categories: the military, the private non-subsidized and the specialized hospitals had a far bigger share of the total than Java (335 hospitals in the Outer Provinces compared to 122 on Java). In general, as the population ratio for Java and the Outer Provinces was more or less $2: 1$, the hospital ratio was the reverse 1:2 (230:403). ${ }^{82}$ Although the economic situation was not very stimulating during the 1930s, hospitals managed more or less to maintain their position. The total number of hospitals in 1930 was 632, incl. specialized hospitals (see table 10). The number of 1940 was 633 (see table 18). The regional hospital distribution as such only provides a limited view of the availability of hospital care. After all, the bed capacity per hospital varied considerably. For instance, the capacity of the 3 central public hospitals on Java together was 2,642 beds, whereas the average capacity of the other 45 public hospitals was only 56 beds.

81 Indisch Verslag 1938, Ziekeninrichtingen, 73-74, adapted with information from the database about the years 1937 to 1940. During those years 8 new hospitals were opened and 1 closed.

82 Population Java 42 million, Outer Provinces 19 million equals a ratio of about 2:1. 
Table 19 Estimated hospital capacity $1940^{83}$

\begin{tabular}{|c|c|c|c|c|c|c|c|}
\hline Region & Public & Private $\mathrm{Hos}$ & itals & $\begin{array}{l}\text { Sub Total } \\
\text { General } \\
\text { hospitals }\end{array}$ & $\begin{array}{l}\text { Special } \\
\text { Hospitals }\end{array}$ & Military & Total \\
\hline & & Subsidized & Non-subs. & & & & \\
\hline Java \& Madoera & 6,644 & 6,061 & 6,479 & 19,184 & 952 & 10,535 & 30,671 \\
\hline Sumatra & 856 & 2,079 & 7,227 & 10,162 & 1,571 & 4,434 & 16,167 \\
\hline Borneo & 224 & 283 & 2,990 & 3,497 & 476 & 213 & 4,186 \\
\hline Celebes & 224 & 661 & 3,904 & 4,789 & 238 & 1,257 & 6,284 \\
\hline Moluccas & 112 & 283 & 2,492 & 2,887 & 190 & 318 & 3,395 \\
\hline Other Islands & 392 & 94 & 1,495 & 1,981 & 333 & 719 & 3,033 \\
\hline Outer Provinces & 1,808 & 3,400 & 18,108 & 23,316 & 2,808 & 6,941 & 33,065 \\
\hline Java \& Outer Prov. & 8,452 & 9,461 & 24,587 & 42,500 & 3,760 & 17,476 & 63,736 \\
\hline
\end{tabular}

Looking at both tables (18 and 19) and using only the columns Public and Private (Leaving specialized and military out) we find 186 general hospitals for civilians on Java and Madoera with a total of 19,184 available beds in 1940 . This means 0.46 beds per thousand inhabitants. However, for the Outer Provinces there were available 286 general hospitals for civilians with 23,316 beds, which is 1.23 bed per thousand inhabitants.

These figures imply:

- that, although the Javanese had to travel less far to find a hospital, the average number of beds at their disposal was far lower than the capacity available to inhabitants in the Outer Provinces.

- that, although the availability of hospital beds per inhabitant in the Outer Provinces was about three times the capacity on Java, the accessibility in terms of distances was far better on Java than in most of the Outer Provinces.

Elaborating on Tables 18 (hospital distribution) and 19 (capacity distribution), I tried to relate the distribution of hospitals and their capacity to the size and density of the population and worked out a few examples, completed with additional information on the availability of medical staff and on catchment areas. ${ }^{84}$

To calculate an acceptable distance between the hospital and its prospective attendants (catchment area) we may look back at the system designed by A.E. Wasklewicz. His intention was to minimize the distance people had to walk to an inoculation post.

83 The capacity averages were obtained by simply dividing the total capacity known per hospital category by the number of its hospitals. Thus, a calculated estimate of the distribution of hospital beds in the different regions and islands was found. To check the underlying calculations, see Annex 6.

84 Catchment area equals the quotient of area and number of hospitals. The distance range is the average range a patient has to walk to visit a hospital. The range may be a radius of $9 \mathrm{~km}$ from the hospital (Jogjakarta) or a radius of $25 \mathrm{~km}$ (East Coast of Sumatra). It is calculated by using the formula: $\sqrt{ }($ catchment area/3.14). Worked out for the East Coast: $\sqrt{ }(1970: 3.14)=\sqrt{ }$ $627=25$ (figures are rounded). 
He designed a system by which the longest distance to an inoculation centre was five paal $(7.5 \mathrm{~km})$. A more attainable approach in the case of hospitals, is the one adopted by the British-Indian government. I looked into the situation of British India in the 1930s. The Director-general of the India Medical Service reported the existence of a network of hospitals and dispensaries, located at suitable central sites. This network was established by the Government, local bodies or municipalities. For the situation in the 1930s, a village that was situated at a distance of more than 10 miles from one of the units of this network was rarely to be found.$^{85}$ In 1936 there were 6,191 hospitals and dispensaries for a total area of roughly 834,100 square miles, so the average area served by a hospital/dispensary was 135 square miles. (See for a detailed survey Appendix 7).

In a radius of 10 miles of rural hospitals, the area to be serviced would be 314 square miles or approximately 800 square $\mathrm{km}$. If we take such an area as acceptable from a point of view of physical accessibility, we may have a suitable reference.

Unfortunately, there was no pair of regions that combined comparable sizes with comparable density of population either for Java, or for the Outer Provinces. So, for comparison, I took two regions: one sample in which both regions had about the same size and one in which the population numbers were similar.

In the first sample, the distances to bridge for patients would be more or less the same, at least when the availability of hospitals would be the same. The other sample refers to similar population numbers. The province of East Java and the region of West Sumatra had similar areas from a point of view of size (see table 20). East Java had an area surface of 42,451 square $\mathrm{km}$ and West Sumatra 49, 778 square $\mathrm{km}$.

Table 20 Hospital ratios for regions with similar area size

\begin{tabular}{lll}
\hline Description & East Java & West Sumatra \\
\hline Area & $42,451 \mathrm{~km}^{2}$ & $49,778 \mathrm{~km}^{2}$ \\
Population & $13,093,000$ & $1,910,000$ \\
Density & 308 per km² & 38 per km² \\
Hospitals & 67 & 16 \\
Beds & 5,920 & 678 \\
Doctors & 231 & 30 \\
Catchment area & $634 \mathrm{~km}^{2}$ & $3,111 \mathrm{~km}^{2}$ \\
Distance range & $0-14 \mathrm{~km}^{2}$ & $0-31 \mathrm{~km}^{2}$ \\
Beds per 1,000 & 0.45 & 0.35 \\
Doctors per 10,000 & 0.18 & 0.45 \\
Population served/hospital & 195,418 & 119,375 \\
\hline
\end{tabular}

85 Bradfield, E.W.C., An Indian Medical Review 1938 (New Delhi 1938), 34-44. 
The areas were comparable, but the population numbers varied greatly: East Java counted a population of more than 13 million inhabitants, whereas West Sumatra had less than 2 million inhabitants. The population density was 308 per square $\mathrm{km}$ for East Java and 38 for West Sumatra.

Comment: The population of East Java had on average, one doctor per 60,000 inhabitants, while this figure for the inhabitants of West Sumatra was one doctor per 22,000. The availability of beds per thousand did not differ much, but the Sumatra patient needed to bridge twice the distance from their home to a hospital, compared to his fellow-patient in East Java. Figures for East Sumatra and for the whole of Sumatra will be presented later. There is a big difference between the East Coast of Sumatra and the West Coast. The ratio of beds per 1,000 inhabitants was 20 times the number of the West Coast on a population of about 1.7 million (see Table 22). For the whole of Sumatra, the ratio of beds per 1,000 was much larger than the ratio for the West Coast (table 23 mentions 1.22, compared to 0.35). Two regions, which had a comparable number of inhabitants, but quite different surface areas present a different picture. The Priangan region on West Java and the Government of Celebes, excluding Menado were chosen (see table 21).

Table 21 Hospital ratios for regions with similar population size

\begin{tabular}{lll}
\hline Description & Priangan Residency & Government Celebes \\
\hline Population & $3,449,000$ & $3,093,000$ \\
Area & $13,655 \mathrm{~km}^{2}$ & $100,457 \mathrm{~km}^{2}$ \\
Density & 253 per km² & $31 \mathrm{per} \mathrm{km}^{2}$ \\
Hospitals & 18 & 47 \\
Beds & 2,430 & 1,350 \\
Doctors & 88 & 28 \\
Catchment area & $759 \mathrm{~km}^{2}$ & $2,137 \mathrm{~km}^{2}$ \\
Distance range & $0-16 \mathrm{~km}$ & $0-26 \mathrm{~km}^{2}$ \\
Beds per 1,000 & 0.70 & 0.44 \\
Doctors per 10,000 & 0.26 & 0.09 \\
Population served/hospital & 191,600 & 65,800 \\
\hline
\end{tabular}

Comment: Patients in the Priangan Residency had fewer hospitals than the Celebes region, but in the latter region, the hospitals were far smaller. This means that the ratio: beds per thousand (0.44) was unfavourable, compared to the Priangan ratio (0.70). The ratio doctors/10,000 population was three times larger in the Priangan Residency. The range distance to bridge for patients fell within the benchmark of 800 square $\mathrm{km}$ for the Priangan Residency, but the distances in the Government of Celebes fell far beyond the above range. To complete these comparisons, let us consider the situation in two regions that were 
exemplary in their rational planning of hospital establishments: the plantation belt of the East Coast of Sumatra and the Djokjakarta principality on Mid-Java (see Table 22).

Table 22 Two regions compared: Djokjakarta and East Coast Sumatra

\begin{tabular}{lll}
\hline Description & Djokjakarta & East Coast Sumatra \\
\hline Population & $1,559,027$ & $1,693,200$ \\
Area & $3,200 \mathrm{~km}^{2}$ & $94,600 \mathrm{~km}^{2}$ \\
Density & 487 per km² & 18 per km² \\
Hospitals & 17 & 48 \\
Beds & 1,356 & 12,595 \\
Doctors & 30 & 76 \\
Catchment area & $188 \mathrm{~km}^{2}$ & $1,970 \mathrm{~km}^{2}$ \\
Distance range & $0-8 \mathrm{~km}^{2}$ & $0-25 \mathrm{~km}^{2}$ \\
Beds per 1,000 & 0.87 & 7.4 \\
Doctors per 10,000 & 0.19 & 0.45 \\
Population served/hospital & 91,700 & 35,300 \\
\hline
\end{tabular}

Comment: While patients living on the East Coast of Sumatra area may have had to travel almost 3 times the distance that the Djokja patient needed to cover, the East Coast patient would find about 9 times as many beds. One hospital in the Djokja area served a population of roughly 92,000, while one hospital on the East Coast of Sumatra served a population of 35,000 inhabitants. These comparisons between regions will be completed by an overview of the different ratios per island and for the whole of the archipelago (see Table 23).

The same ratios for The Netherlands and for British India offer some comparison.

In 1942, a total number of 472 general hospitals had been founded in the Netherlands Indies. These hospitals were joint by a number of 82 specialized hospitals. Only hospitals for civilians and no military hospitals were included. The Netherlands Indies as a whole are still far away from the bed ratio of the Netherlands, though the region of the Moluccas shows a ratio that comes very near the Dutch ratio. Compared to the British Indies the availability of beds per thousand for the NI as a whole is about three times more favourable. The geographic division of the public, private and specialized hospitals in the Netherlands Indies is graphically presented (see Figure 33). 
Table 23 Distribution of hospitals and beds in relation to areas and population, $1940^{1}$

\begin{tabular}{|c|c|c|c|c|c|c|}
\hline Country/region & $\begin{array}{l}\text { Area in } \\
1,000 \mathrm{~km}^{2}\end{array}$ & $\begin{array}{l}\text { Population } \\
\text { Millions }\end{array}$ & $\begin{array}{l}\text { Density } \\
\text { per km² }\end{array}$ & $\begin{array}{l}\text { Number } \\
\text { Hospitals }\end{array}$ & $\begin{array}{l}\text { Number } \\
\text { Beds }\end{array}$ & $\begin{array}{l}\text { Beds per } \\
1,000 \\
\text { Population }\end{array}$ \\
\hline Netherlands ${ }^{2}$ & 33 & 7.8 & 236 & 279 & 28,400 & 3.60 \\
\hline British India $^{3}$ & 2,160 & 247.6 & 115 & 2,905 & 63,793 & 0.26 \\
\hline Netherlands Indies & 1,904 & 60.7 & 32 & 472 & 42,500 & 0.70 \\
\hline \multicolumn{7}{|l|}{ Of which: } \\
\hline Java & 132.2 & 41.8 & 315 & 186 & 19,184 & 0.46 \\
\hline Sumatra & 473.7 & 8.3 & 17 & 125 & 10,162 & 1.22 \\
\hline Gvt. Borneo & 539.5 & 2.2 & 4 & 43 & 3,497 & 1.59 \\
\hline Celebes & 189.0 & 4.2 & 23 & 58 & 4,789 & 1.14 \\
\hline Gvt. Moluccas & 496.5 & 0.9 & 2 & 35 & 2,887 & 3.21 \\
\hline Res. Timor & 63.3 & 1.7 & 26 & 19 & 1,505 & 0.89 \\
\hline Res. Bali \& Lombok & 10.3 & 1.8 & 175 & 6 & 476 & 0.26 \\
\hline
\end{tabular}

${ }^{1}$ Military and specialized hospital beds are excluded from the numbers.

${ }^{2}$ Source: Verslagen van de Geneeskundige Hoofdinspectie (Reports of the Medical Chief Inspector).

${ }^{3}$ Report on the Census of India, 1931.

What about similar colonial environments in the neighbourhood? How did hospital care develop in this period in the Philippines, Malaysia and French Indochina?

As mentioned before, in the Federated Malay States a steady increase of the number of patients took place, not only in outpatient numbers, but also inpatients. In 1929, the Federated Malay States counted four European hospitals, 34 District hospitals, three women's hospitals, two leper asylums, five gaol hospitals, one mental hospital and 30 dispensaries not attached to hospitals. In total 117,639 inpatients were treated and a further 878,158 people received outpatient care from hospitals, clinics, travelling dispensaries or the dispensary boats that operated on the Perak and Phang Rivers. In 1936, the Federated states had 6,733 hospital beds on 1,847,951 inhabitants. The Straits Settlements (Singapore, Penang, Province Wellesley, Malacca) had 3,333 beds on 1,160,391 population. Together more than 10,000 beds on 3 million people, equalling $3 \%$ beds. ${ }^{86}$

In French Indochina, the increase of the numbers of indigenous patients that looked for hospital treatment grew to almost 15 times the initial ones in 1889: in 1936 it was 336,000 compared to 23,000 . The development of hospital admissions was paralleled by the number of outpatient consultations. Rough estimates arrive at 15,000 beds for French Indochina. In the area of Saigon 10 hospitals had together a capacity of 6,500 beds and in the State of Annam 20 hospitals were counted with 3,500 beds. Compared to a population of about

86 Leonore Manderson, Sickness and the State, Health and illness in Colonial Malaya, 1870-1940 (Cambridge 1996) 63-65. 
24.6 million, a ratio of $0.61 \%$ o beds was calculated. ${ }^{87}$ During the 1920 s the maternity clinic became an indispensable pendant of the hospital, an institution that showed an eager consumption of Western medicine. Those clinics served the economic motive of the colonization and looked after the propagation of Western notions on hygiene. ${ }^{88}$

Outer Prov Java $\quad$ Totals

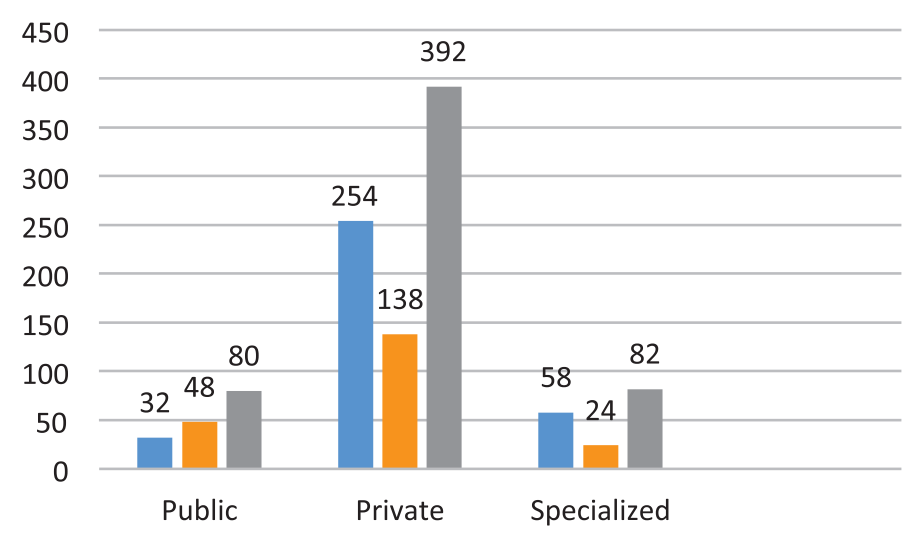

Figure 33 Categories of civil hospitals, 1940

In 1936, when the Commonwealth of the Philippines was inaugurated, Dr. Jose Fabella was named Chief of the Bureau of Health. He made an inventory of the existing health facilities, which consisted of 11 community and social centres, 38 hospitals, 215 puericulture centres, 374 sanitary divisions, 1535 dispensaries and 72 laboratories. ${ }^{89}$ By the end of 1938 , there were about 160 hospitals with a total capacity of approximately 0.76 bed per 1,000 of population (USA 9.7 beds per 1,000 of population). This included hospitals directly under jurisdiction of the Commonwealth Government, general hospitals, university hospitals, leprosariums, penal hospitals, mission hospitals, private hospitals and maternity hospitals. ${ }^{90}$ In British India, as we saw, there were almost 3,000 hospitals in 1936. The number of beds was almost 64,000 on a population of 247.6 million. Compared to the Malay states this meant an availability of $0.26 \%$, almost ten times less than that colonial situation (3\%o)

87 Simmons, Global Epidemiology, 411-412.

88 Laurence Monnais-Rousselot, Médecine et colonisation, l'aventure indochinoise 1860-1939 (Paris 1999)

89 Department of Health (Philippines), https://en.wikipedia.org/w/index.php? Title: Department_of_Health_Philippines (last visited June 29, 2016).

90 Simmons, Global Epidemiology, 115-116. 
and compared to the situation of the Netherlands Indies, about three times less $(0.7 \%$ ). For a detailed comment see Appendix 7.

\section{After May 1940: War time and occupation}

An abrupt and unforeseen end of the colonial period was near when the Germans invaded the Netherlands. The situation of the colonial government seemed rather uncertain, but business was carried on as usual until a few years later the Japanese took possession of Indonesia.

\section{May 1940 and the German occupation}

Even after May 1940, when The Netherlands were conquered by the Germans, health care in the Netherland Indies continued its services at an almost unaltered level with one exception. At the time of the German invasion, the NI government had put all Germans and members of the NSB into internment, including medical doctors. ${ }^{91}$ In Deli, part of eastern Sumatra, more than 200 Germans were interned, among whom 75 missionaries and doctors of the Rheinische Mission. The German director of the municipal hospital of Medan was discharged from his function. ${ }^{92}$ But the training courses for doctors and nurses continued to educate new students, even at an unprecedented scale. From May 1940 to February 1942 the Faculty of Medicine delivered a total of 102 licensed doctors. ${ }^{93}$

\section{The Japanese occupation March 1942}

On 8 March 1942, the Dutch general H. ter Poorten signed the document of surrender with the commander of the Japanese $16^{\text {th }}$ army, Imamura Hitoshi, at the airport Kalijati, near Bandoeng. After the capitulation about 93,000 soldiers were put into prisoners of war camps. The European population in the Outer Provinces was almost immediately put into internment camps. On Java, this policy was initially limited to the totoks, the colonial upper class. From July 1942 to the beginning of 1943, 29,000 men, 25,000 women and 29,000 children were interned. The occupying forces tried to induce the Indo-European population to cooperate and integrate into the Indonesian society because of their administrative and technical skills. The majority refused and held on to the Dutch nationality. Their positions were transferred to Indonesians. ${ }^{94}$

91 Anthony van Kampen, Een kwestie van macht (Bussum 1975) 162-175. The NSB (Nationaal Socialistische Beweging) was the fascist political movement in NI, a subsidiary of the NSB in The Netherlands.

92 G. Mak, De eeuw van mijn vader (Amsterdam 2000) 239. Transl.: The century of my father.

93 This figure was obtained by counting the Verslagen on licensed students in 90 successive numbers of the GTNI of 1940 to February 1942.

94 J.J.P. de Jong, De waaier van het fortuin, 569-580. 
What did the new situation imply for the functioning of hospitals? Some hospitals were transformed into concentration camps. The writer and journalist R. Kousbroek describes his stay in the Soengei Sengkol camp, a coolie hospital of the Ahrendsburg tobacco plantation and mentions a few other camps housed in hospitals: The Brastagi sanatorium of the Senembah company and the large hospital of the Siantar Dokterfonds in which from March to December 1942 a number of 800 women and children were interned. ${ }^{95}$ On Java, the Dutch who lived in the central regions were interned into the military hospital at Ambarawa. About $16 \%$ of them did not survive the war. The fate of a great many Javanese inhabitants was hardly better, since some of them had to work under almost slavery circumstances as 'economic soldiers' or so-called romushas. Their number is estimated at some 10 million and hundreds of thousands of them died because of undernourishment, illness and exhaustion, among others while working at the Burmarailway. Moreover, part of the population of Java was stricken by famine in the last war years because of the failure of the Japanese rice-policy. The promised support for nationalistic leaders was soon put aside and all political activities were forbidden on Java. ${ }^{96}$

There were few positive messages about the continuing of services of the missionary and company hospitals, but the public hospitals managed to carry on with their staffs of Indonesian doctors and nurses. After the war ended and Allied forces had restored Dutch administration in 1945, some missionary hospitals were used by the Indonesian army during the fight for independence. The Modjowarno hospital was called the Rumah Sakit Pertahanan Surabaya di Mojowarno (Defense hospital Surabaya of Mojowarno) and the Indonesian staff of some other missionary hospitals seemed to have no problem in joining the cause for freedom. ${ }^{97}$ On Java and Sumatra numerous autonomous fighting groups formed, mainly put together by militant young people (Pemoedas), dedicated to the cause of independence. They used the strident cry: Bersiap (Wees paraat, Be prepared!). During four years their fights went on, while the Dutch administration tried to restore the colonial situation. During this so-called bersiap period many hospitals succeeded in starting up their usual services. ${ }^{98}$ Especially the missionary hospitals soon carried on their business as usual and the few public hospitals that were left, the three central public hospitals and the psychiatric ones, also regained their services. Not much is known about the company hospitals during the Japanese occupation and immediately afterwards, during the bersiap period. However, after the so-called souvereiniteitsoverdracht (deed of conveyance) Dutch business kept a dominant position in independent Indonesia. No

95 R. Kousbroek, Terug naar Negri Pan Erkoms (Amsterdam 1995)40, 51-60 and 78-84.

96 W. van den Doel, De geschiedenis van Nederland overzee, zo ver de wereld strekt (Amsterdam 2011) 306-322.

97 Soedjatmoko, Sejarah Rumah Sakit Kristen Mojowarno (History of the Christian Hospital Mojowarno), a memorial book at the occasion of the $100^{\text {th }}$ anniversary of the hospital in 1994.

98 Herman Burgers, De Garoeda en de ooievaar, Indonesië van kolonie tot nationale staat (Leiden 2010) 400. 
doubt, a number of company hospitals kept going. The economic decolonisation was achieved in 1957, when all Dutch companies were nationalized. ${ }^{99}$

\section{SUMMARY}

This Chapter discussed the social, political and economic events that characterized the 1930s, before discussing the hospital developments of that period. A strong influence could be attributed to the Great Depression, which involved large cuts in the government budget. As the government subsidies were curtailed, the health care budgets were cut as well. Besides the measures needed to deal with the economic crisis, efforts were needed to restore law and order, as the nationalist opposition took aggressive actions. The opposition played the game of non-cooperation, when elected in local, regional and national councils.

The developments in the field of epidemiology were discussed: the plague continued to make victims, especially in West Java and the Public Health Service agencies that screened the youth at schools, discovered many cases of tuberculosis. More efforts were made to record leprosy cases and to motivate these patients to accept voluntary isolation. The history of a leprosy institution in the Moluccas was presented. The disease took a threatening form in this part of the NI, but even more on the islands of Bali and Lombok.

After the political and general health care developments, the situation of hospitals was discussed. In this last episode, four developments that characterized the period 1930-1942 were discussed. The first was the process of decentralization that had a large impact on public hospitals, but also on other services of the Public Health Service. At first sight, decentralization was a logical step on the road towards emancipation and autonomy. In the different provinces and regencies, the population could decide on the social, educational and health facilities that it wanted. But the process was centrally arranged. So, the population did not decide on questions such as the financing of a hospital, a school or a community centre, but had to deal with decisions, accomplished by other bodies in former times. The government public hospitals already existed in the towns and regional cities, which in the 1930s received the financial burden that was involved with the transfer of ownership. Admittedly, the central government at first tried to persuade the lower public agencies to take over voluntarily, but when the takeover stagnated, the issue was forced by Government Decree.

The second development discussed, was the sudden increase of health care activities from the side of Roman Catholic missionary congregations. At first, these organizations were handicapped by the lack of missionary doctors and, therefore, missed the necessary encouragement by government subsidies. But from about the mid-twenties and more so in the 1930s, this handicap was overcome and many hospitals, auxiliary hospitals and outpatient clinics were established. Most of them were located in the Outer Provinces.

99 Henk Schulte Nordholt, Indonesië na Soeharto, Reformasi en Restauratie (Amsterdam 2008) 253. 
The third development was the founding of health facilities in the sugar belt of Java (East Java and the Principalities of Djokjakarta and Soerakarta). The sugar barons took notice of the Djokja hospital developments and the Deli experiences and decided to join in the interest of the workers, but mostly in order to improve the operational reliability of their annual campaigns. Sometimes this participation took the form of joint ventures with other private organizations, like missionary societies. Often, the hospitals, auxiliary hospitals and outpatient clinics were combined efforts of a group of sugar plantations. In this way, 28 hospitals and 64 outpatient clinics were established and 16 other hospitals were subsidized. Finally, the specialized hospitals too witnessed expansion during the 1930s. Especially the sanatoria for tuberculosis patients expanded in number and capacity, but the facilities for leprosy patients and for eye patients also grew in number and capacity and this despite the economic depression.

As for the availability of hospital capacity, efforts were made to position this variable in relation to areas and populations serviced. For reference a combination of two examples was taken: the vaccination circles introduced by A.E. Wasklewicz and the principle of British Indian hospitals to aim at serving populations within a circle with a radius of 10 miles from the establishment. An area of about $800 \mathrm{~km}^{2}$ around a hospital might be considered within reasonable distance of the population to be served (having a radius of 10 miles from the establishment). As such only the Residencies on Java (Priangan, Jogjakarta) and the province of East Java had hospitals established within reachable distances on average. For the Residencies in the Outer Provinces: Celebes $\left(2.137 \mathrm{~km}^{2}\right)$ and Westcoast Sumatra $(3,111$ $\mathrm{km}^{2}$ ), the areas served were about 3 to 4 times acceptable levels. Even the plantation belt of the Eastcoast of Sumatra, often mentioned because of its rational planning and efficient hospital management, did not meet the standard and had an average area serviced per hospital of $1,970 \mathrm{~km}^{2}$.

On balance a lot of treatments was given in outpatient clinics. The dispersion of these settlements should be taken into account as well. In British India the picture was rather positive: the areas covered by hospitals had a square mileage of 135 on average (the reference point of 314 miles $^{2}$ being the equivalent of $800 \mathrm{~km}^{2}$ ) and only 2 provinces (Sind and Baluchistan) exceeded the reference, but then all facilities were taken into account, including dispensaries without accommodation for in-patients. If we also take into consideration the outpatient clinics in the Outer provinces together with the hospital establishments, the average value would be much more acceptable. 


\section{MAP 4 HOSPITALS MISSIONARY ORGANIZATIONS 1940}

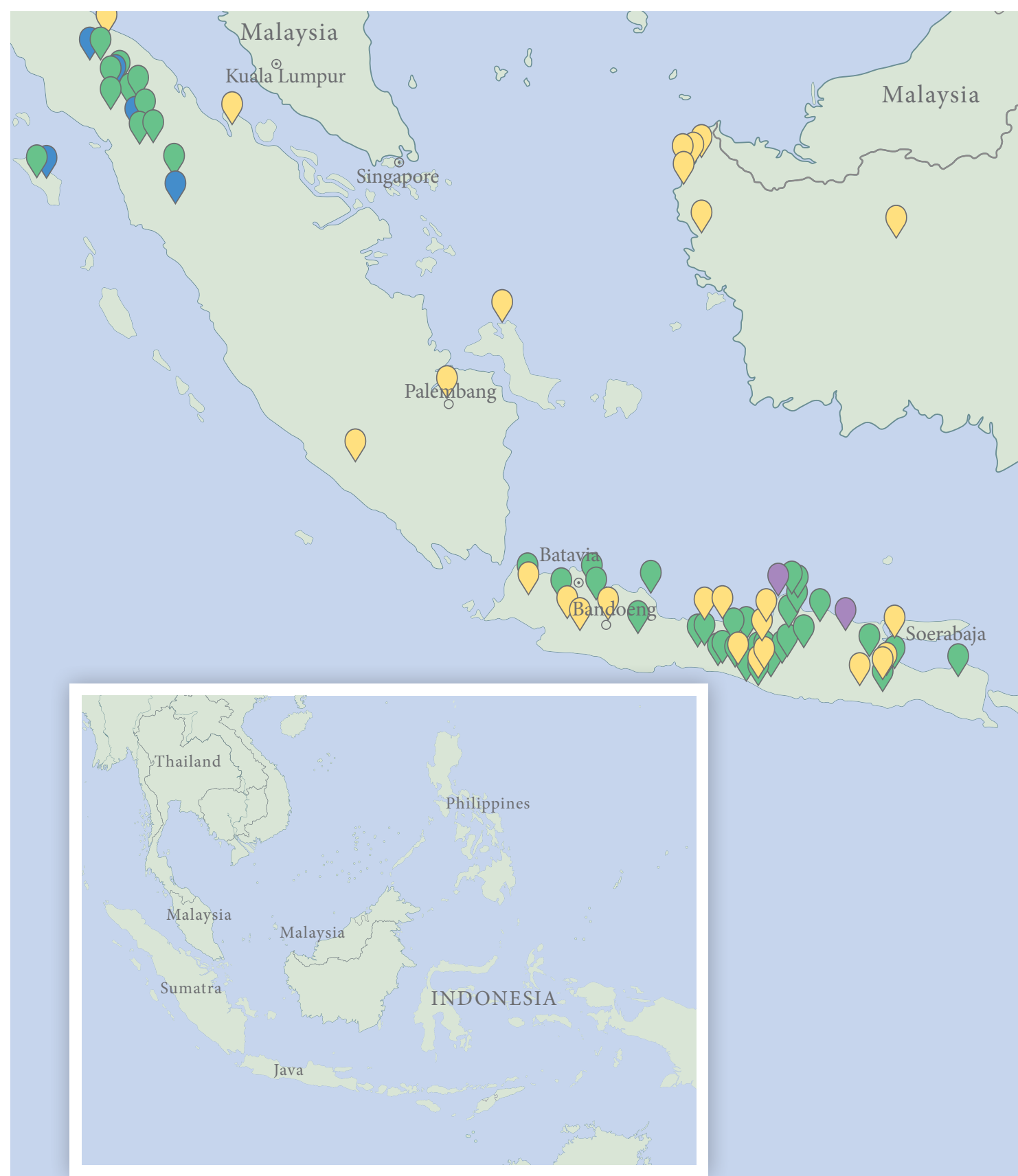




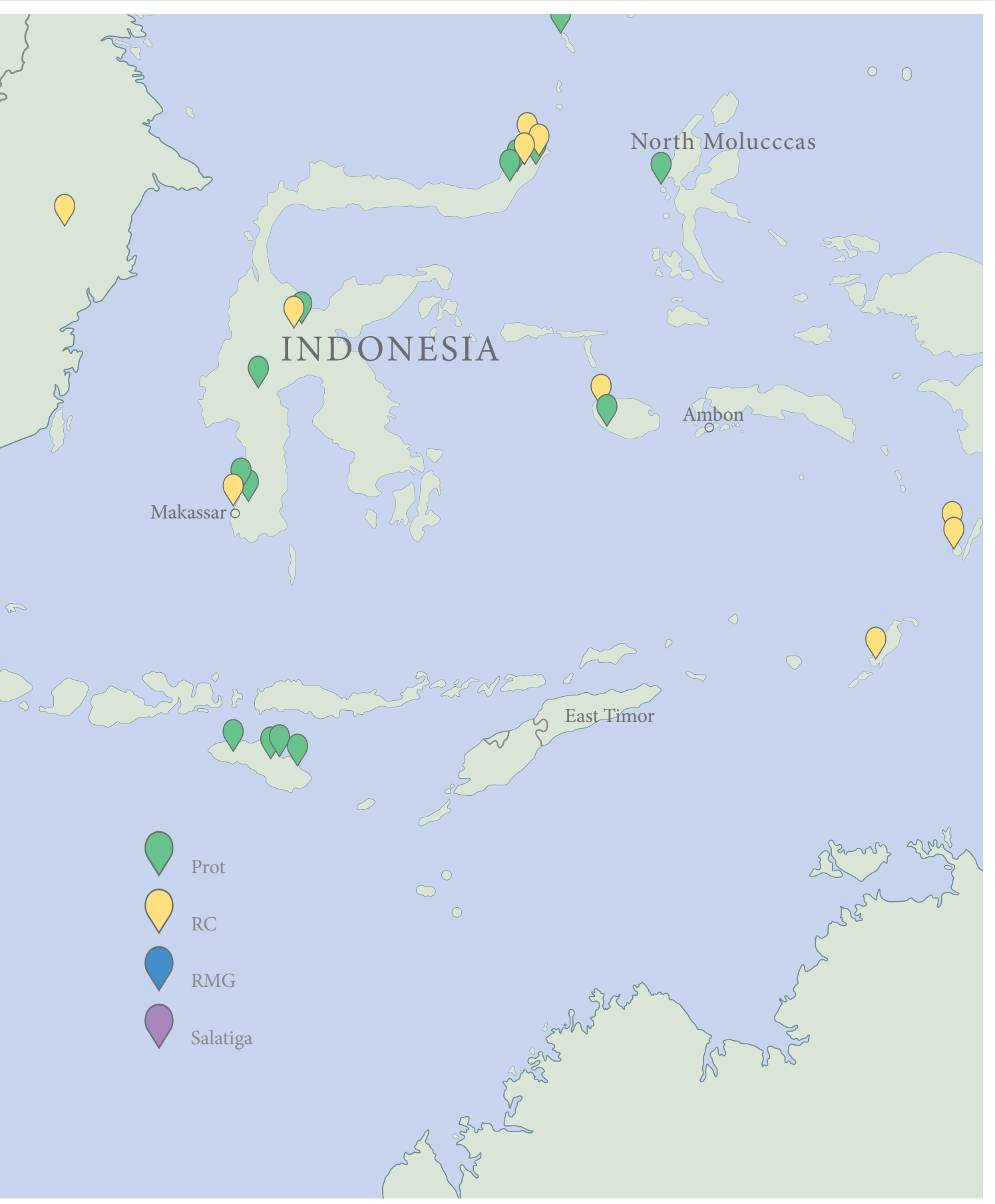




\section{MAP 5 MISSIONARY HOSPITALS JAVA, 1940}

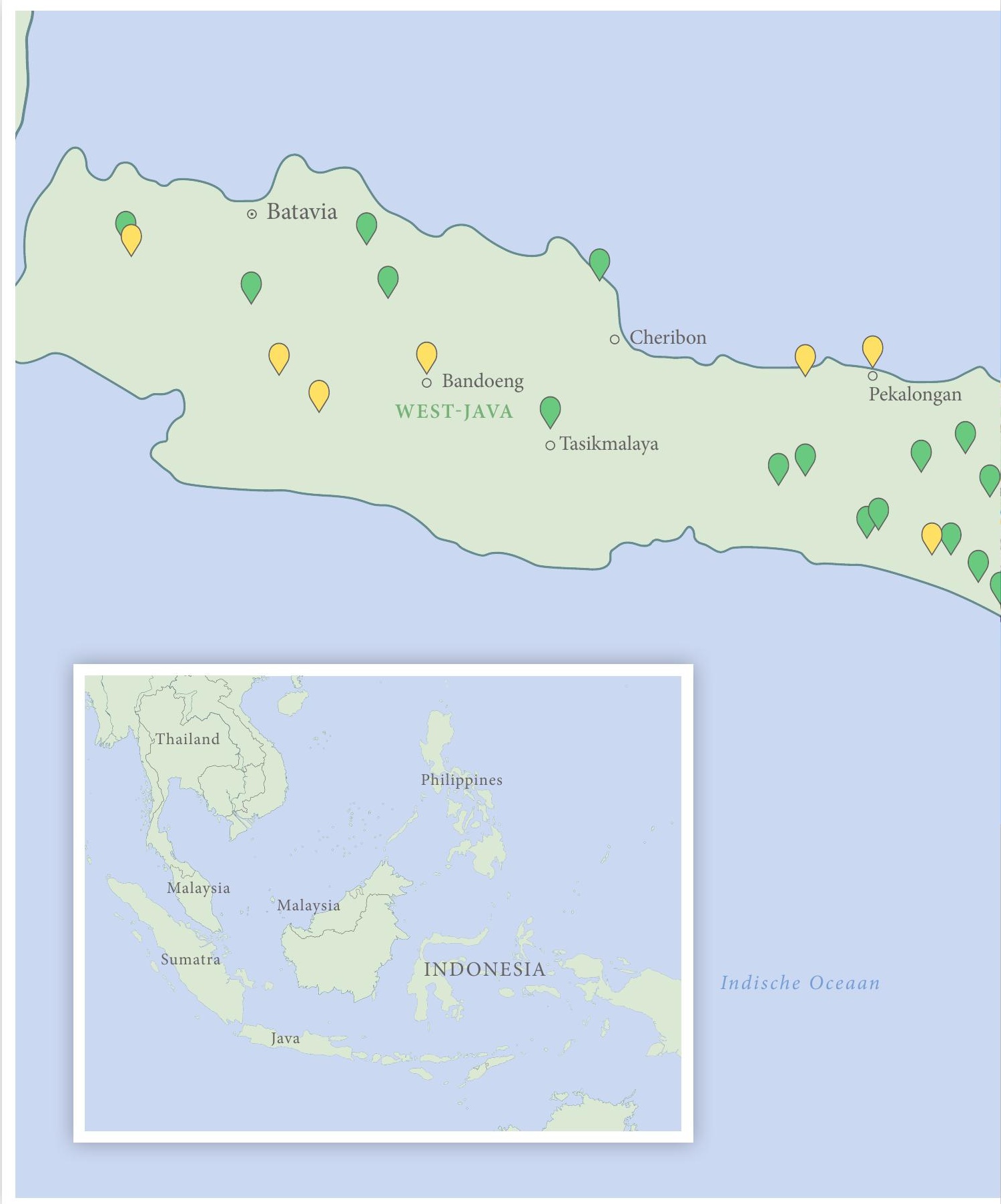





\section{CHAPTER 7}

\section{REFLECTIONS ON THE BIRTH OF A HOSPITAL SYSTEM}


The main objective of this book has been to fill in a gap in the historiography of health care in the Netherlands Indies. The object was the civil hospital, part of a system that emerged during the last colonial years, the period 1890 to 1942.

The research presented here, confirmed that the focus on that last period and the periodicity into three sub-periods was right. The latter, because each period had its own characteristics and dynamism and thus shaped an essential part of the developing hospital system. However, before elaborating on these issues, the reader was taken back to the first days of (proto) colonial presence in the archipelago to consider the VOC hospitals. These hospitals were founded mainly for the VOC employees, soldiers and Chinese and European populations. As these groups represented rather small communities, compared to the indigenous population, the number of these hospitals remained small. At the end of the VOC-period, just before 1800, 13 hospitals existed (8 on Java and 5 on the other islands). The history of these hospitals was unedifying, as the mortality rate in these hospitals was continuously rising, especially during the $18^{\text {th }}$ century. Nevertheless, their function was more similar to real hospitals than the so-called gasthuizen in the home country.

Chapter 2 gives an account of these 13 hospitals and explores the reasons that led to their foundation and maintenance, while Chapter 3 is reserved for the $19^{\text {th }}$ century. In that century, civil hospitals gradually deteriorated and military hospitals took the lead in hospital care. Military doctors, who were called health officers, dominated the dual health care situation that prevailed. Many of them received an assignment to fulfil civilian tasks together with their military duties. They supervised the vaccination programme and looked after the enforcement of laws concerning epidemics. Halfway the $19^{\text {th }}$ century, the scarcity of medical personnel induced the chief of the military and civil medical services to start training indigenous doctors. In 1851, the dokter djawa school was established near the military hospital at Batavia.

By the end of the $19^{\text {th }}$ century, the medical personnel consisted of 80 European civil doctors, 180 European military doctors and 110 dokters-djawa. Regarding the availability of civil hospitals, their number was officially 79 in 1890, but more than half this number related to very small indigenous hospitals or small institutions for syphilitic patients. As far as the military was concerned: there were 3 large and 25 garrison hospitals. The occurrence of military ziekenzalen (dispensaries) was double that number and there were also a few specialized institutions. These 90 military health care establishments had a capacity of about 3,500 beds at that time. The overall picture by the end of the $19^{\text {th }}$ century still showed a domination of the military in two aspects: regarding medical manpower and hospital capacity. 


\section{HOSPITAL SYSTEM: NAISSANCE AND DEVELOPMENT}

Central in this thesis are the last decades of colonial rule, from 1890 to 1942 . Chapters 4, 5 and 6 cover this period, which converges with the development of the modern hospital system in The Netherlands. These Chapters correspond with a sub-division of this period into three distinct phases.

During the first period (1890 - 1910) considerable changes took place in colonial policy. There were two aspects of this change. In the first place territorial: the surface area occupied by The Netherlands almost doubled as a consequence of territorial warfare. The second was ideological: In the period before 1900, the colony was considered to exist for the benefit of The Netherlands and was expected to deliver annual contributions to the national budget. From 1900 the so-called ethical policy was formulated and became the leading principle in organizing colonial affairs. In Java and the Outer Provinces emphasis was put on the development of education, irrigation and emigration. The last two were stimulated because the Javanese population had become impoverished by population growth and insufficient productivity of indigenous food crops.

The private health care in this period was stimulated and benefitted from subsidizing programmes. From 1890 onward, initiatives to establish hospitals were taken by new parties, such as plantation owners and missionary societies. The Government of the Netherlands Indies itself improved the status of indigenous hospitals and promoted some of them to Government Civil Hospitals. The status of the employees improved, they became civil servants and staff recruitment and their training became the responsibility of the NI Government. At the same time, a process was started to make the civil health service independent and have it managed by its own chief. Eventually, this led to a complete separation of the military and the civil health services. During the turn of the century, research developments took place that produced diagnostic and therapeutic improvements. Some specialized hospitals like those for syphilis and beriberi closed or were converted into general hospitals. The combination of the new ethical policy, initiatives of new parties and medical progress, led to an increase in civil hospitals. The building of new hospitals, improvement of equipment and expansion of the training programmes resulted in a better reputation for hospitals and improved opportunities for treatment.

At the beginning of the period there were only 79 civil hospitals. By 1909 their number had increased to 250 , of which $2 / 3$ had acquired government status. The available budget for civil hospitals (subsidies for private and budgets for government hospitals) increased accordingly.

The second period, 1910-1930, was one of expansion of the private hospital sector. In 1911, a law was passed that installed the new Burgerlijke Geneeskundige Dienst (Civil Medical Service) with a new head, called Chief Inspector. New laws that promoted the establishment of new private hospitals followed up with the first subsidy law in 1906. The remaining 
indigenous hospitals and hospitals for syphilitic patients were combined and became government civil hospitals. The NI government allowed missionary societies, especially on Java, Sulawesi and the Moluccas, to expand their mission fields. These organizations established a substantial number of hospitals, together with a large number of churches and schools. The missionary organizations managed to establish a network of health care institutions, which covered a much larger area than one hospital might do on its own. The first experiment with such a network started in the so-called Principalities, a semiautonomous area, and was imitated in other regions. It became known as the Djokja-system. In the meantime, other experiments were carried out on the East Coast of Sumatra by plantation companies, which had joined forces and established well-organized central hospitals with laboratory facilities and well-documented case histories of patients. The former City Dressing Stations, which had a bad reputation, were replaced by new wellequipped hospitals at Batavia, Semarang and Soerabaja. They were called Centrale Burgerlijke Ziekenhuizen (Central Civil Hospitals).

In the 1920s, it was decided to change the focus of the Civil Health Service from direct health care towards preventive and positive health care. In 1924, this was underlined by changing its name to Dienst der Volksgezondheid (Public Health Service). Actually, this change was facilitated by private parties, which had taken over substantial parts of direct health care by establishing hospitals. The department of Education and Worship, hosting the Public Health Service, furthered the policy to hand over the management of Government Civil Hospitals to local and regional governments, a policy already expressed in 1901, when decentralization was formulated as one of the main government objectives.

By the end of this second period the private hospitals took care of the greater part of existing general hospitals and the remaining hospitals were almost equally divided between military hospitals and Government Civil Hospitals. Company hospitals expanded ten times the numbers of 1910 .

The third period, 1930 to 1942, was largely influenced by the Great Depression. During the first years, Government agencies had to economize and this had a considerable impact on the Public Health Budget. In 1936, it was decided that the pace of decentralization should be intensified. From then on, cities, regencies and provinces were required to take care of the establishment and operational duties of public hospitals and public outpatient clinics. By the end of this third period, only a few general hospitals remained under the management of the Public Health Service and most of the other former government hospitals (126) were taken over by municipalities and local autonomous bodies. A few had been taken over by missionary organizations or companies. Despite the poor economic situation in the 1930s, many new hospitals were established by missionary organizations in this period, most of them by Roman-Catholic missions. 
Moreover, on Java the 1920s and 1930s witnessed the rise of many company hospitals, established by co-operating sugar companies. The combined result, together with the hospitals in the Outer Provinces (mostly on Sumatra), was a number of almost 300 general hospitals, run by plantations, mining companies and commercial or industrial firms. Some of these hospitals (about 50) were contracted by the NI government.

During this period and the previous one, the type of specialized hospitals changed. The hospitals for syphilitic and beriberi patients disappeared, but several new sanatoria were established to take care of tuberculosis patients and many psychiatric institutions were instigated. Hospital capacity was on average 7 beds per 10,000 inhabitants with large differences between various regions. On the East Coast of Sumatra the average rose to 12, whereas the dense population of Java had only 5 beds per 10,000 inhabitants. The availability of doctors for the population was 0.2 per 10,000 inhabitants with smaller regional differences: the best-served region being Sumatra (0.45), while Java had only $1 / 3$ of this capacity (0.16).

\section{Evaluation}

Looking at the characteristics of each period and the factors that determined the outcome of the 3 periods, one might roughly distinguish: During the first period, the public hospitals for civilians took over from the military hospitals. During the second period, private hospitals took over the main role in civil health care from the public hospitals. During the third period, regional and local administrative agencies took over hospital care from the central government. In the end, a decentralized system of civil local and regional hospitals was spread over the archipelago.

This system was divided into public hospitals, private hospitals and specialized hospitals.

\section{Answering questions}

After 1890 and after careful preparations, an independent Civil Medical Service (CMS) was set up. This CMS accelerated the pace of health care development and greatly influenced the birth of the modern hospital system. The rise of this system would probably have been delayed for quite some time, if it had missed the political support, which came about with a change in political paradigm. The selfish premise that the NI colony was for the benefit of the homeland changed drastically: from 'batig slot' (a positive balance) to ethical principles. From 1910, important improvements in the health prospects of thousands of indigenous patients could be achieved, as these patients acquired access to outpatient clinics and hospitals. Apart from the many private organizations, the central and local administrations henceforth took the responsibility to organize direct and indirect health care for the population. This development had been unknown in the previous centuries, when the VOC and military organized health care. Prior to 1890, health care was preoccupied with mainly European civilian, commercial and military interests. The main 
exception was vaccination against smallpox. After 1890, the structure of the civil hospital system, that emerged during the last five decades of the colonial period, was built up with four components: the general public hospitals, general hospitals of charity organizations, general hospitals of companies and a large group of specialized hospitals. To arrive at a more or less complete picture of this hospital system a database was built. This database contains many characteristics of the individual hospitals and classifies these into categories, places, regions and islands. It was constructed to provide answers to questions posed in the introductory Chapter. These questions were:

- Who were the initiators of hospitals and what were their motives to establish hospitals? The who and why question.

- When did these initiators establish hospitals and according to which pattern of distribution? The when and where question.

- How were hospitals constructed and organized? Design and organization questions.

- What about supply and demand of hospital services? The market question.

- Finally: May we speak of a hospital system and what made it a system?

\section{Who and Why}

To start with the who and why-question: For a long time, the larger part of the $19^{\text {th }}$ century, the Government of the Netherlands Indies maintained the position, that it basically accepted no responsibility for direct health care as provided by hospitals. Nevertheless, in the course of time the same government had established some hospitals for civilians. These hospitals continued to exist, being financially and operationally controlled by the government. The exception to the general rule of non-involvement was formulated thus: provisions would be made available only for the medical treatment of pradjoerits (native policemen), syphilitic prostitutes, insane and badly wounded patients or other patients taken in by the police force. In 1890 at the start of this study, there were 79 officially recognized hospitals. Beside a few general hospitals, the City Dressing Stations, the recognized hospitals treated and nursed mainly specific groups such as psychiatric patients, cases of leprosy, prostitutes suffering from syphilis and patients who were hit by epidemic diseases. Not only in the Netherlands Indies, but also in British India, both homelands established a policy that central governments would not interfere with direct health care issues. Charity organizations or local government managed direct curative health care. Only with the threat of an epidemic or a threat to public order would the central government take responsibility. The why-question regards the main initiators of Western health care and more specifically the central government. In the $19^{\text {th }}$ century, the central government took responsibility for dangers to the public health such as epidemics (smallpox and cholera). Diseases such as leprosy, insanity and syphilis required government intervention and induced the establishment of institutions to contain such diseases in the interest of the colonial community. The colonial authorities took a narrow view of their responsibility, hence, most 
hospital establishments did not serve the general public, but only specific groups and purposes. Therefore, at the end of the $19^{\text {th }}$ century, there were only five general civil hospitals in the main cities of Java and a few recognized inlandsche hospitals with a relatively large number of specialized civil hospitals for syphilitic patients, leprosy cases, psychiatric patients, beriberi patients and patients affected by (other) epidemic diseases.

Only a few private providers were active in the health care field. This was limited to a few plantations on Sumatra, a few mine companies and a few charity organizations and these only during the last decade of that century.

Why did the hospitals increase in numbers after the turn of the century?

First of all, one should bear in mind that after 1890 there took place a large territorial expansion of the colony. This was accompanied by wars and large areas of land were brought under cultivation. Intensive explorations for ore and oil took place in this period. These activities brought with them the need to create facilities for a growing workforce of foreign labourers.

The why and by whom questions regarding the main period of this thesis, the last 50 years of colonial rule, required a more differentiated answer, depending on the persons or agencies that initiated hospital care then. These initiators may be roughly divided into three parties: private companies (mining companies, plantations, industrial and commercial companies), public parties (local and central government) and private charity organizations (such as missionary organizations, Salvation Army, Chinese communities and a few Indonesian political organizations).

The first main factor in the increase may be ascribed to the large group of companies. Agricultural companies took the lead by investing largely into health care, mostly by founding hospitals. Company hospitals were concentrated in the plantation belt of the East Coast of Sumatra and the Sugar belt of Java. The plantation companies of the East Coast of Sumatra were the first to invest in health care, since they witnessed considerable loss of life due to diseases within their workforce of immigrants (Chinese and Javanese). Their primary motive was financial: It was expensive to finance the replacement of plantation labourers, who were in a bad physical condition or had died. Gradually, a kind of health care developed to support the companies in decreasing the morbidity and mortality among their workforce. A second important stimulus came from the public health authorities (CMS). The CMS, and provinces, regions or municipalities all initiated hospitals, as they became gradually aware of the health situation of the population and felt responsibility towards improvement. The largest incentive to take up these responsibilities came from the so-called ethical politics. For the first time, this was officially proclaimed by Queen Wilhelmina, when addressing the Dutch parliament in 1901.

The third factor in the expansion was charity organizations and especially missionary organizations. These organizations felt responsibility towards improvement of the health situation, even when it was not their primary objective. By bringing their gospel, they 
founded communities and being confronted by the poor physical conditions of their converts, they felt a need to bring education and health care to these communities.

Summarizing the motives and incentives that led to the forthcoming of a system of hospitals around the archipelago, the main incentive was the one the companies felt, the need to keep their workforce healthy and alive. In the end, their contribution to the NI hospital system proved to be the largest. In the second place came humane motives, cherished by charity organizations and local and central administrations.

Why did the indigenous population make use of hospitals?

Up to this point, the discussion of the why-question has been restricted to the providers of hospital care. However, the why-question applies to the receivers of that care as well. Did the indigenous population express the wish to receive this type of care? The answer to both questions is the same: at first, that is before the $20^{\text {th }}$ century, both parties were reluctant, the provider in giving and the receiver in accepting hospital care. Therefore, the hospital care at this stage of the colonial era bore a compulsory character. The insane, syphilitic or leprosy patients were forced to undergo inpatient treatment or at least separation from the community. There was a need for enforcing the health care, from the point of view of the provider because security was at stake and on the side of the receiver, because no one was prepared to voluntarily undergo hospital treatment.

Looking at the main period of this thesis, the compulsory character gradually made way for a voluntary use of services. Though for some regions the use of the hospital beds failed to be optimal, on Java and Sumatra the rising occupation rates of hospitals did prove that gradually the willingness to accept a hospital stay grew. There were a few incentives that furthered this use, most of all the distribution of medicine (quinine and salvarsan) for free or against low prices. Then, the quality of hospital care improved by introducing new therapeutic techniques and by constant training of hospital employees. This resulted in therapeutic successes and thus hospitals were able to inspire confidence in the achievements of their services. Besides, Western health care could be seen as care in last resort, after the traditional efforts had failed. But it should be kept in mind that willingness to be treated seldom translated in financial contributions to the costs of stay and use of Western health care; the indigenous patient kept falling back on the traditional health system as well, on the doekoen, whom he had to pay.

Thus far the why-question was answered for the suppliers and receivers of hospital care during the period of research, the years 1890 to 1940 . These answers beg the by-whomquestion: The actors were the central and local government, next to charity organizations and various types of companies. Besides, in a number of cases initiatives were taken by individual doctors or individuals from the Chinese community. 


\section{Where and when were hospitals founded?}

At first, most of the initiatives took place on the island of Java, which was the most populated island of the entire archipelago. This was at least true during the period before 1890-1940. It was true during the VOC-era and during the $19^{\text {th }}$ century. In the last decades of that century, the island of Sumatra gradually took its place, when a number of hospitals were established in the plantation belt of its East Coast. By 1920, this island drew about level with Java. The survey in Chapter 6 noted an almost equal number of hospitals on Java (227), Sumatra (218) and the remaining islands (214). What does this mean in terms of accessibility? From the point of view of distances to be covered and population density, an exercise was made, starting from an example that was worked out for the situation of the British-Indian subcontinent. It was reasoned that, if a hospital had a catchment area of some $800 \mathrm{~km}^{2}$, the maximum distance a patient had to travel from home to this hospital, would be about $16 \mathrm{~km}$. This calculation method may be questioned: in a country with mountains and few roads, the patient cannot walk as the crow flies and often has to make detours. Still, this approach of a catchment area of 800 square $\mathrm{km}$ may be used as a benchmark for accessibility. However, it appeared that only 13 out of 19 Residencies on Java met this benchmark and none of the regencies on the other islands. This meant that more than $2 / 3$ of the total number of hospitals was not within an acceptable distance of the population they had to serve. Clearly, the Java population was comparatively better off, even if it could not count on the same ratio of beds per 1,000 inhabitants as some of the other islands. Living in relative close vicinity to hospitals probably compensated this disadvantage.

The question remains how health care was distributed in the less densely populated islands. If patients were inclined to seek for Western health care, could it be found? And if no hospital could be found, could they fall back on some alternative health care facility such as a Lands polikliniek (government outpatient clinic), doctor's post or medical depot? To answer this question, one might examine the public health facilities and the facilities put up to regulate smallpox vaccination. It is likely that the division of the Netherlands Indies into a great many health districts looked after the health care needs of a much larger part of the population than hospitals might have done alone. Either a European doctor, private or military, or a dokter-djawa /Inlandse doctor was available per health district. Besides, looking at the hospital statistics, it turns out that in addition to 170 general government hospitals a number of 435 polyclinics (outpatient posts) were available. As the missionary hospitals and the central hospitals of plantations made use of a diversified network of health care facilities, one may assume that the number 435 may be doubled or even tripled. The protestant missionary organizations looked after 237 polyclinics in 1938 (compared to 31 hospitals and 70 auxiliary hospitals). Regrettably, no statistics are available for other private outpatient clinics. 
To return to the question when, In the two decades from 1910 to 1930, the three principal actors (Companies, government and missionary societies) founded the greater part of the hospitals. This was the period of large expansion of hospital establishments, especially those of private hospitals (missionary and company hospitals). The hey-days of the company hospitals were from 1890 to 1920 . The most important period for charity hospitals was during the decades 1900 to 1930 . The government, for its part, looked after the expansion of institutions for psychiatric patients.

The period 1910 -1930 saw the establishment of 370 general hospitals for civilians. The private hospitals could claim in this rise three times the government contribution. In the meantime, a large part of the hospitals for special diseases or for special groups of patients disappeared. A few new categories replaced them, but this group no longer dominated the hospital scene as before. Whereas before 1890 the civil hospitals for leprosy, syphilis, psychiatry and beriberi outnumbered the general civil hospitals, in 1938 they hardly represented $30 \%$ of the total number of hospitals (general and specialized together).

\section{Characteristics of design and organization?}

In most cases, the architecture of hospitals in the Netherlands Indies followed the paviliontype of design. This type of architecture was characterized by single level facilities with all rooms on the ground floor. The patient wards, operation theatres, pharmacy, administrative and housekeeping departments were all on the same level and often mutually connected by wide lanes, paved with tiles and open on all sides, but covered by a roof. The characteristics of a tropical environment dictated this type of architecture. The rooms were airy, fresh air could be easily let in and the gangways were protected against heavy tropical rainfall. The layout of the building-complex was not restricted by the scarcity of land. Attention was paid to the availability of clean water, opportunities for waste disposal and absence of malaria-prone marshes.

As for the internal organization and staffing of hospitals: In the instruction to directors of the central government hospitals, the medical director was appointed as head of all personnel. He was responsible for the internal organisation of the main hospital departments: operating theatres, outpatient department, nursing departments and, if available, laboratory personnel and pharmacy. In the smaller hospitals, he also supervised the auxiliary departments. In the much larger central hospitals, the supervision of departments such as the laundry, kitchen, storerooms and bookkeeping was delegated to an administrator. In the psychiatric hospitals a so-called Huismeester was charged with these latter duties. As the objectives of hospital organizations were similar, either established in the Netherlands, Great Britain or the colonies, their internal organization did not differ much. Only the division of functions between the European and indigenous personnel varied from that of Western countries. This was established in the naming of functions: Nurses (European) existed alongside with mantri-nurses (indigenous). Medical doctors 
(European) were found alongside dokters djawa or inlandse physicians.

The training, recruitment and management of a professional staff took some decades to reach acceptable standards. In the course of time, internal hospital facilities and external training institutes existed for most disciplines, but initially nearly all the medical and nursing personnel was recruited from the Netherlands and other European countries. During the decades 1930-1940, training facilities for mantri-nurses were available at three Central Civil Hospitals and at some Government Civil Hospitals. The mantri nurses of the three CBZs had the opportunity to complete a midwife training in addition to their initial nursing training. Many private charity hospitals provided training for mantri-nurses and a midwife training as well. Training for indigenous doctors (NIAS) and dentists (Stovit) was available at Soerabaja, whilst the Medical Faculty at Batavia gave the training for fully qualified medical doctors. The training of vaccinators took place at Bandoeng at the Landskoepokinrichting. The training of pharmaceutical assistants was established in the Apotheker School (Pharmacy School) at Batavia. The training of laboratory assistants (Chemical and bacteriological) was established at the Eykman Institute, Central Laboratory of the Public Health Service at Batavia.

As for the finances of hospitals: whereas the category nursing fees represented the largest income category in Western hospitals, this was quite different in the hospitals of the Netherlands Indies. Quite a few hospitals did not charge their patients at all, except for medicines. The missionary hospitals depended on government subsidies and gifts from their parent organization, while many companies joined forces to establish central hospitals that treated the coolies and their families without charge. The purpose of government hospitals was originally to treat the poor and destitute persons of the indigenous population and the hospital admission was regulated according to income level and composition of family. Insurance companies in the NI mostly focussed on other risk categories, such as fire insurance or funeral costs. Still, in the larger hospitals nursing in first or second class stays provided some income, especially when European patients were admitted. Middle income indigenous patients had to pay according to the class of stay or according to their monthly income and family situation.

\section{May we speak of a Medical Market?}

In the introduction I formulated the following hypothesis: The founding and development of hospitals were essentially based on economic motives. The needs of patients were not leading in the establishment of hospitals.

Satisfaction of physical and psychological needs is a central theme in economic theory. However, it is hardly possible to measure health care needs or more specific the need of a hospital service with a population that has no purchasing power. In the absence of solid data, we need to use some indicators. 
During this research the following was observed:

- At first, the decision makers were Europeans and their motives to found hospitals had an economic nature. However, these motives did not originate from the health services as such, (supply and demand), but were held, because of a production process or commercial interests that had to go on; This situation was found in the VOC period, but also during the period 1890 to 1942, as far as company hospitals were concerned.

- Secondly, the start of a public hospital was only approved, if and when the acting Resident or assistant Resident declared that the community was in need of such a facility. Subsequently, the same Resident was in charge of supervising duties. He regularly had to check the state of the buildings, the supply of food and equipment and the financial accounts; This was the case with public hospitals for civilians during the period 1900 to 1930.

- When the decision was taken and the hospital was founded, its use offered an indication of the real health care need. Sometimes, soon after the foundation of the hospital, the health care need expanded and more hospital capacity was created. Demand exceeded so to speak supply. This situation occurred now and then, but was more common after 1930, when the occupancy rate of hospitals was rising.

When we speak about a medical market for the Netherlands Indies, we suggest that the suppliers of hospital services addressed the purchasing power of consumers who were in demand of their services. This was not the case in the period 1890 to 1942 . The indigenous patients did not have sufficient purchasing power to pay the cost price of hospital services. In some cases, they paid for medication, but mostly they applied for a free hospital stay and free treatment.

So, I think it is too early to speak about a medical market for the Netherlands Indies. Nevertheless, the latter concept is often used as a metaphor and much later, after the Dutch left the Indies, this concept appeared to be viable.

In my opinion the concept of the medical market needs to be defined in terms of supply and demand and of the main vehicle that determines this process, the pricing mechanism. It is obvious in the situation of the NI population, that the purchasing power was practically absent for the indigenous consumer of health care services. Intermediaries such as insurance companies that could meet this absence were also missing. Nowadays most of the markets for goods and services are characterized by so-called models of 'imperfect competition' (monopolistic and/or oligopolistic situations of demand and supply), but even this concept does not apply. This concept refers to the operation of the pricing mechanism, which was practically absent in the NI situation in the period discussed. There is one exception though: The European citizens and some of the Javanese nobility paid for the services rendered and in some cases the NI government acted as an intermediary in refunding owners of private hospitals for their services towards designated categories of patients (soldiers, poor 
indigenous patients). I estimate the part of the hospital income that came from customers or intermediaries to be less than $10 \%$ of the hospital account.

Consequently, one may conclude that, in general, colonial hospitals did not originate from a more or less independent demand and supply process. Pricing of services did not result from the interaction of the parties on the demand and supply side of the game. The Government dictated the prices for services of Government hospitals (civil and military). Company hospitals usually did not charge their workers and missionary hospitals normally only charged the medicines delivered, but not the hospital stay (except for Europeans).

\section{May we speak of a hospital system?}

A system requires an organized structure of mutually dependent components and shows coherence and efficiency.

Considering individual initiatives, such as the Djokja experiment and its followers and the central hospitals of the East Coast of Sumatra, the qualification system may be appropriate. These hospitals functioned within a structure of mutually dependent components and the resulting services functioned efficiently.

With respect to the total outcome of hospitals and their distribution over the archipelago in 1942, we may conclude that the infrastructure was made up of subsystems that were mutually complementary. The general hospitals were supplemented by specialized hospitals. The public hospitals were complemented by private hospitals. There was also a hint of rational planning of facilities. From 1906, the subsidy regulations demanded a written statement of the Resident or Assistant Resident that the District or Residency needed the proposed hospital. This very much resembles the Verklaring van behoefte (Declaration of necessity) that the Dutch Wet Ziekenhuisvoorzieningen of 1971 (Hospital Facilities Act) required before a licence was issued to establish a new hospital or rebuild an existing hospital. Helpful in achieving a rational planning of facilities was the division of health districts over the country. For each health district a medical doctor or indigenous doctor was assigned to look after direct health care and vaccination, while there was the intention (in 1906) to establish at least for each health district a small hospital or outpatient clinic. It was considered irrelevant, whether the hospital was public or private. Later, as the process of decentralization advanced, the health districts on Java were converted into provincial, municipal and regency health services, each with an expanded package of health care components, including direct health care, hospitals and outpatient clinics. There were selfregulating elements in the hospital system: When specialized hospitals no longer were needed, they were closed or converted into another category. This was the case for beriberi hospitals and hospitals for syphilitic women. New needs created new facilities, such as the increased number of tuberculosis cases resulted in a number of sanatoria. A degree of central direction of the system was present, when we look at the Civil Medical Service as owner of public hospitals and provider of subsidies for private hospitals. 


\section{OUTCOME: A DECENTRALIZED SYSTEM OF PRIVATE AND PUBLIC HOSPITALS}

The partners in the development from a rudimentary to a fully-grown hospital system were public and private parties. At first, the main public party, the NI Government controlled this development by acknowledging indigenous hospitals and awarding a public status to these institutions. Further, most private parties could claim subsidies from the government, when it was agreed that the community had an urgent need for its own hospital. Gradually, the most independent partners, the companies, gained ground and by 1930 they even dominated the hospital scene. By then they had established more than $50 \%$ of the general hospitals.

Sometime before, the Reorganization Commission of 1906 had declared that each health district should aim at having a hospital. If possible, the hospital should be established by the local or regional community, but if not otherwise possible, by initiatives of companies, missionary societies or a combination of these parties. The maxim: Private if possible, public if necessary was thus reversed. Actually, in the course of time the public participation in establishing and maintaining hospitals diminished until by 1940 only $1 / 6$ of the total of general hospitals had a public status.

During the last 50 years of colonial rule a differentiated landscape of public and private hospitals arose, which was decentralized with regard to public hospitals. By definition it was also decentralized for the private components, as these resulted from initiatives that were related to agrarian, mining or industrial settlements or to residential permits (missionaries). At least one hospital for each region or health district, had not yet been accomplished. A distribution proportional to population and areas would take some time, but the result of all the public and especially the private initiatives was a sound basis for future developments.

We may conclude that the outcome of 50 years of hospital establishment did deliver a hospital system. Albeit with shortcomings, but nevertheless a system that provided a diversified and decentralized infrastructure of direct care to large parts of the population.

\section{COLONIAL HEALTH POLICIES COMPARED}

In the preceding Chapters, health care policies were compared between the Netherlands Indies and other colonial countries such as The Philippines, British India, French Indochina and Malaysia.

An interesting question remains to be discussed: what explains the similarities? At the same time, it may be even more revealing why in some cases different ways were sought for essentially the same problems? It was Worboys who described how in British India very different diseases were approached in similar ways, while in East Africa the same disease (sleeping sickness) was approached differently in separate colonial contexts.

Still, to arrive at an evaluation of similarities and differences, we need to put the same questions that were asked in the introduction to this research: 
Why did other colonial powers make an effort to provide health care to the indigenous populations of the colonies they ruled? What were their motives and how and in which form did these motives materialize in establishment of hospitals? Who were the initiators and where and when did they decide to realize their plans?

It may be not surprising that in most cases economic motives played a dominant role. After all, the main reason to conquer and rule colonies had been for commercial profits. At least for British India and the Netherlands Indies this was clear and for the other countries political as well as economic considerations had been the drive to embark upon colonial enterprises.

As for hospitals, these institutions for the indigenous population were often established to protect the European population against dangers of contamination and of public disorders. As neighbouring colonial health authorities lacked experience with tropical diseases, they feared health hazards for the military (syphilis) and for the European population (epidemics). This was certainly the case with the Americans, who only shortly before 1900 had conquered the Philippines and with the French, who in the second half of the $19^{\text {th }}$ century occupied Indochina.

The history of British India and of the Netherlands Indies differed from the other colonial countries in Asia. Both countries had been dependences of large commercial enterprises (VOC and EIC). This put a stamp on their history for centuries. Before 1800, civil hospitals for the commercial and military European population were only scantily distributed. In British India the first regular medical establishment did not start before 1763, when the Bengal Medical Service was formed. Both for British India and the Netherlands Indies the medical services were predominantly military organized during the $19^{\text {th }}$ century. Western medicine in French Indochina was also largely concurring with military medicine during the 40 years preceding the complete establishment of colonial rule (1850-1890).

The thorough organization of civil health care found its start in British India in 1868 and in the Netherlands Indies no sooner than 1911. This late start had to do with the long held conviction of the colonial governments that regular health care for the civilian population was not their concern. The only health facilities they judged necessary for the population had to do with epidemics and other risks. For example, during the $19^{\text {th }}$ century this policy led to the establishment of so-called "lock-hospitals" (British India) and hospitals for syphilitic women (Netherlands Indies), both for the compulsory treatment of 'diseased women.'

The reason why colonial governments ultimately decided to establish a civil medical service and embarked upon the founding of general hospitals for the civilian population is not quite clear. For the Netherlands Indies this had to do with parliamentary developments in the mother country. Many political parties embraced at the turn of the century a so-called ethical direction. For other countries a 'civilizing mission' was formulated to soften the egocentric course colonial rule had known. These reactions had an impact on education, health care and other areas of civil concern in the colonized countries. 
Although colonial governments were not keen on establishing general hospitals for civilians, other parties did. Many missionary associations founded schools and established hospitals. In the Netherlands Indies this took place from the 1890s. In British India the first regular medical missions were founded and supported by missionaries from the United States who started their work in the southern parts of India by 1830-1840.

From the 1890s another development started in the Outer Provinces of the Netherlands Indies, where plantations needed manpower from abroad, mostly Chinese coolies. As many abuses took place, a Coolie Ordinance was issued which obliged the planters to take care of housing and medical care. Ultimately, this led to well-equipped central hospitals with laboratory facilities. Private initiatives were also taken in British India, where well to do Indian leaders who had earned their money in trade or industry wanted to do something for their fellow-citizens. Arnold introduces this phenomenon under the heading Patronage and leadership and mentions examples, starting with some Parsi sponsors whose example was followed by Hindu and Muslim leaders. Altogether the private hospitals, including mission hospitals, formed about $40 \%$ of the British Indian hospitals. For the Netherlands Indies this was more than double this percentage.

So, economic reasons had mostly inspired the public initiators of hospitals in the Netherlands Indies and in British India. From about 1900, the governments mixed ethical and civilizing motives in their commitments. Missionary zeal inspired the many societies, Protestant and Roman Catholic, that founded health facilities in British India and the Netherlands Indies. In French Indochina, the government worked under a so-called 'mandat civilisateur' with the motto "Vaccinate, record, disinfect." The hospital system was organized strictly vertical, ruled from provincial offices. Although the Roman-Catholic missions had been active in these regions since the $17^{\text {th }}$ century, the anti-clerical policy of the mother country obstructed the expansion of missionary hospital facilities. In these regions too, the timber, rubber and tea plantations maintained hospitals.

Comparing the different colonial situations for epidemiology, there is not much difference in the endemic and epidemic diseases that were prevalent in the four countries. Cholera and smallpox returned at more or less regular intervals. The plague arrived sooner in the other countries than in the Netherlands Indies. Beriberi had a large health impact on soldiers and convicts in the Netherlands Indies and in French Indochina, while in British India the black fever or 'kala azar' made a lot of victims. In all the colonies malaria and leprosy were present and asked for health facilities. The policy of British India was sometimes marked by hesitant operations from fear of cultural or religious opposition. The smallpox policy of the Netherlands Indies seemed most successful and the anti-plague measures had a positive outcome on the hygiene situation of the archipelago. The Americans in the Philippines focused on hygiene measures to bring down the risks for its soldiers and educationalists. They paid a lot of attention to the care of leprosy patients too. As for hospitals to treat the prevalent diseases, the general hospital and its outpatient clinics took 
care of most afflictions. Specialized hospitals were established for eye diseases, mother and child, psychiatry, tuberculosis and leprosy.

In the field of training of medical workers much attention was paid to the training of indigenous doctors, and midwives. By the end of the 1930s, the ratio of European and Indochinese doctors in relation to the population varied from a very low ratio for FrenchIndochina to a high one for the Philippines. As for midwives, different approaches were made to deal with the reluctance of indigenous women to have western trained midwives assist at their deliverances. Some traditional birth attendants were re-educated (French Indochina), some received an elementary practical training and were employed by maternity centres (British India). In the Netherlands Indies no use was made of such policies. Here, in most cases the indigenous midwife received an additional training after their nursing education at the Central Government Hospitals and affiliated hospitals.

As for cooperation or integration between western and traditional health care, few results were booked. At first, Western practitioners depended on the know-how of indigenous healers to find the therapeutic properties of indigenous herbs. During the $19^{\text {th }}$ century the research on traditional medical herbs was stimulated in the Netherlands Indies and led to a series of articles and this knowledge was still used at the turn of the $19^{\text {th }}$ century. Actually, this cooperation experienced a revival, at least in some Indo-European circles in the Netherlands Indies. In British India actions were taken to get Ayurvedic and Unani systems of medicine recognized. In the 1930s this resulted in a Bill by the Bombay Legislative Assembly to regulate the qualifications and to provide for the registration of practitioners of Indian systems of medicine.

The cooperation may have been inefficient and integration was not aspired, but this seemed of no concern to the indigenous population who continued to take advantage of both systems, the traditional ways of healing and the western medicine.

Evaluating the differences and similarities, it may be noted that the pace of hospital development differed greatly between some of the countries mentioned. As it is common practice to look at the number of beds in relation to the size of the population, three countries had by 1940 about the same ratio (Netherlands Indies, Philippines and French Indochina), while British India stayed far behind and the Federated Malay States had progressed most (four times the ratio of the first three mentioned). Still greater differences could be noticed when comparing the availability of medical personnel. The Philippines headed the lines by producing more than fifteen times the ratio of the Netherlands Indies and French Indochina, while British India and the Malay States had about six times more medical personnel in relation to the population than the Netherlands Indies and French Indochina. It appears that the educational efforts of the Americans in their newly conquered colony began to yield. Looking at these results, it should be kept in mind that there were large differences in the vastness of the territories served and the density of populations, as was demonstrated before. 


\section{EPILOGUE}

Though it may seem appropriate to discuss the connection between medicine, imperialism and colonialism, I have tried to avoid the pitfall of valuating remarks on this issue by keeping to the rather descriptive mode. After all, the statement that colonial medicine was a tool of imperialism, is a political-moral judgment, that obscures the historian's lens and that does not add nor distract one hospital from the recorded ones.

And yet I am conscious of the dangerous minefield this study on colonial issues enters, because it is an immense field of experiences, facts, emotions and above all, it is guilt-ridden. It may seem that the plain description of the development of a hospital system does not harbour risks or emotional comments, but this is not true.

To mention a few, not necessarily emotional comments:

The question, who or which parties, initiated the introduction of Western medicine, may be answered by summing up the parties involved. But after summing up, the question may arise: was this a one-direction only, from Europe to the colony, or was there an exchange of ideas and a cooperation of both sides? There is no doubt that it was both ways around, as the exchange of facts and results from local research learns. For instance, it was not the commission Pekelharing (sent from the Netherlands) who found out the real cause of beriberi, but the Laboratory at Weltevreden did.

Another question is about the superiority of Western medicine over traditional medicine. The result of 300 years Western medicine and hospitals had not been encouraging for local populations, as the hospital grounds were bordered by overcrowded graveyards. Around 1900, Western medicine began to understand that not the soil or the air was responsible for devastating diseases, but that the real causes were of a bacteriological, or virological nature. Polluted water, mosquitos and malnutrition were the real causes of cholera, malaria and beriberi. From that moment, Western medicine scored results and gradually inspired confidence with people, but even then there were large crowds, even of European descent, who embraced the traditional ways of healing.

To conclude, the present study was about answering the question: why did Western medicine go to East Asian countries and why did it implement its institutions in those regions? It was not intended to present a eulogy on Western medicine. 



\title{
APPENDICES
}

\author{
APPENDIX 1 - 7 \\ SOURCES AND LITERATURE \\ BIBLIOGRAPHY \\ CURRICULUM VITAE
}

LIST OF FIGURES AND TABLES

GLOSSARY

ABBREVIATIONS

INDEX OF SUBJECTS 


\section{APPENDIX 1}

\section{SUMMARY REPORT ABOUT HOSPITALS $1877^{1}$}

\section{Civil Hospitals were found in the following residencies on Java}

Batavia (3): The Chinese hospital and the City Dressing Station took care of indigenous patients. Tangerang: prostitutes and some other patients in an annex of the local prison; Krawang (3) According to a Government Decision of 1861 a former Leprosy hospital could be used as indigenous hospital; Pamanoekan: the local landlord made provisions for a kind of hospital for his people; Tjiassem: The local landlord of the private possession Tjiassem made a local hospital available too;

Preanger (3) Bandoeng: a small hospital, also available for patients from other parts of the Residency. Soekapoera: a small hospital also available for patients from other parts of the Residency. Tjandjoer: a small hospital also available for patients from other parts of the residency.

Cheribon (1) A building of brick stones and roof tiles was established as indigenous hospital. Pekalongan (1) In 1864, a brick building was established in the principal town of this residency for sick prostitutes, but since 1871 this building was used for general diseases of indigenous persons.

Semarang (2) The local City Dressing Station and the Chinese hospital in this town took care of indigenous patients.

Soerabaja (3) indigenous patients were nursed in the City Dressing Station of Soerabaja. Grissee: This Afdeeling (subdivision of Residency) had an indigenous hospital that admitted patients from the Afdeelingen Lamongan and Sedayoe as well. Modjokerto: This Afdeeling had a pendoppo (open hall) of the pasangrahan (lodging house) that was organized to take care of patients from the local population.

Pasoeroean (2) At the principal town of this Residency, a hospital for the indigenous patients was established and at Malang: this town had also an indigenous hospital.

Probolinggo (1) In the principal town a stone building was established with the name of Javanese hospital in which sick prisoners and poor indigenous persons were nursed. The latter group only seldom.

Banjoewangi (1) Soekaradja: indigenous patients could be admitted to the hospital of the Agriculture Establishment at that place.

Soerakarta (1) A private charity hospital for patients suffering from leprosy and skin diseases. Djokjakarta (1) A charity organization at Lowanoe attended indigenous patients. Madioen (1) In the principal town a primitive building served as City Dressing Station.

1 Schoute, "De geneeskunde in NI gedurende de 19e eeuw", GTNI 75 (1935) 10, 828-835. 


\section{Outer islands}

The inventory study of the Director of Public Works made clear that in the Outer Islands no particular hospitals for indigenous patients existed in 1877. In most cases prisons and military hospitals opened their doors for patients from the local communities.

Only in SE Borneo a private hospital existed for personnel of the mining company at Pengarang (1).

Taken together the total number of reported indigenous hospitals in 1877 amounted to 24, including City Dressing Stations and Chinese hospitals. Beside the City Dressing Stations, Chinese hospitals and indigenous hospitals, patients were looked after in the sick bays of prisons and in military hospitals in some places. The report of 1877 mentions the following military hospitals (25) and prisons (12) that sometimes had beds for the indigenous population. Besides, there were 15 hospitals for sick prostitutes.

\section{Military Hospitals on Java and the Outer islands (25)}

\section{On Java (12)}

The military hospitals of Serang (Bantam), Buitenzorg (Batavia), Semarang (only psychiatric patients), Willem I, Oenarang, Salatiga, Pelantoengan (all five Residency Semarang), Tjilatjap (Banjoemas), Bagelen and Poerworedjo (Bagelen), Soerakarta (Soerakarta) and Ngawie (Madioen) admitted civil patients from the local population.

\section{On the Outer Islands (13)}

On Borneo (South-eastern Residency): The military hospitals of Bandjermasin and Amonthay took care of indigenous patients if they disposed of free beds. On Celebes an occasion of hospital care for the civil population was offered at the military hospital of Makasser. The same applied to Amboina in the military hospital of that place. The military hospitals of Padang, Fort de Kock, Padang-Pandjang, Siboga (all four established on the West Coast of Sumatra) admitted patients from the local population. At Palembang (South Sumatra) three military hospitals at Palembang, Lahat and Tebing Tinggi admitted persons from the civilian population, as far as vacancies existed. On Bangka, the military hospital at Muntok admitted indigenous patients. On Riouw, indigenous patients were admitted in the military hospital of Tandjoeng Pinang.

\section{Prison sick bays (12+)}

On Java and the Outer Islands some prisons opened the doors of their sick bays for nonprisoners. 


\section{On Java (6)}

The prisons of Tegal (Tegal), Sidhoardjo and Bawean (Soerabaja), Japara (Japara), Ngawie and Madioen (Madioen) were mentioned in this respect. ${ }^{2}$

\section{On the Outer Islands (6)}

The prisons of Bandjermasin and Amonthay (SE Borneo), Makasser and Menado (Celebes), Ternate (Moluccas) and Koepang (Timor) were mentioned in this respect.

\section{Hospitals for syphilitic prostitutes in 1877 (15)}

The report mentioned facilities for syphilitics at:

Tangerang (Batavia), Indramajoe, Koeningan, Tjiamies (Cheribon), Tegal, Pekalongan, Koedoes (Japara), Pegirian (Soerabaja), Bezoekie, Banjoemas, Poerbolinggo, Bandjarnegara, Tjilatjap (Banjoemas), Ngawie (Madioen) and Palembang (Sumatra).

2 The text makes it clear that in many other Afdeelingen (administrative entities within the Residencies) prison sick bays were available for the sick local population, although they were not mentioned explicitly in the report. 


\section{APPENDIX 2}

\section{LEPROSY INSTITUTIONS $19^{\text {TH }}$ CENTURY UNTIL 1910}

\begin{tabular}{|c|c|c|c|c|}
\hline Island & Place & $1850-1860$ & 1890 & $1890-1910$ \\
\hline Moluccas & Molanen & Founded $<1853$ & No patients & \\
\hline Banda & Pulo Pisang & Replaced in 1853 & No patients & \\
\hline Ternate & Castella & Removed in 1856 & 2 patients & \\
\hline Celebes & Tumumpah & Removed in 1855 & No patients & \\
\hline Celebes & Modelemo & Founded in 1856 & Closed & \\
\hline Riouw & Riouw & Built in 1828 & Chinese financed & \\
\hline Bangka & Rangau & $\begin{array}{l}\text { Founded in } 1849 \\
\text { ( } 300 \text { beds) }\end{array}$ & Closed & \\
\hline Sumatra & Benkoelen & Founded in 1847 & Closed & \\
\hline Sumatra & Palembang & & Kemang Pampang (22 patients) & \\
\hline Sumatra & Medan & & & 1894 (100 beds) \\
\hline Sumatra & Tandjong Poera & & & 1897 (Chinese) \\
\hline Sumatra & Bindjei & & & 1898 (20 beds) \\
\hline Sumatra & Hoeta Salem & & & 1905 \\
\hline Sumatra & Kota Poe Amal & & & 1900 (9 patients) \\
\hline Sumatra & Palembang & & & 1909 \\
\hline Sumatra & Laoe Si Momo & & & 1908 \\
\hline Sumatra & Landschap Peurenka & & & 1900 (9 patients) \\
\hline Borneo & Singkawang & & & 1897 \\
\hline Borneo & Temadjoe & & & 1900 (6 patients) \\
\hline Java & Soerakarta & & Wangkang (94 patients) & \\
\hline Java & Djokjakarta & & Loano (52 patients) & \\
\hline Java & Pelantoengan & & $\begin{array}{l}38 \text { patients } \\
\text { (of whom } 27 \text { Europeans) }\end{array}$ & \\
\hline
\end{tabular}




\section{APPENDIX 3}

POPULATION OF JAVA $1910^{3}$

\begin{tabular}{lcrrr}
\hline $\begin{array}{l}\text { Gewesten } \\
\text { (Residencies) }\end{array}$ & $\begin{array}{c}\text { Number of } \\
\text { Regencies }\end{array}$ & Indigenous & Other & Total population \\
\hline Bantam & 3 & 891,541 & 3,849 & 895,390 \\
Batavia & 1 & $1,999,978$ & 109,374 & $2,109,352$ \\
Preanger & 5 & $2,681,962$ & 14,805 & $2,696,767$ \\
Cheribon & 5 & $1,682,273$ & 26,732 & $1,709,005$ \\
Pekalongan & 5 & $1,969,450$ & 20,836 & $1,990,286$ \\
Semarang & 7 & $2,571,492$ & 43,431 & $2,614,923$ \\
Rembang & 4 & $1,477,197$ & 19,601 & $1,496,798$ \\
Soerabaja & 6 & $2,395,618$ & 41,345 & $2,436,963$ \\
Pasoeroean & 4 & $2,001,554$ & 20,616 & $2,022,170$ \\
Besoeki & 3 & 965,636 & 6,839 & 972,475 \\
Banjoemas & 5 & $1,478,110$ & 8,019 & $1,486,129$ \\
Kedoe & 7 & $2,322,987$ & 15,696 & $2,338,683$ \\
Djokjakarta & 7 & $1,110,814$ & 7,891 & 1,118705 \\
Soerakarta & 4 & $1,577,996$ & 15,060 & $1,593,056$ \\
Madioen & 5 & $1,342,796$ & 6,676 & $1,349,472$ \\
Kediri & 5 & $1,758,579$ & 15,966 & $1,774,545$ \\
Madoera & 4 & $1,487,925$ & 5,364 & $1,493,289$ \\
\hline Total & 80 & $29,715,908$ & 382,100 & $30,108,008$ \\
\hline
\end{tabular}

3 Regeeringsalmanak 1910, p. 4-7 and p. 127-166. 


\section{APPENDIX 4}

\section{POPULATION OF THE OUTER PROVINCES IN $1910^{4}$}

\section{Comments}

Some of the population figures for the Outer Provinces were obtained by approximation. Boomgaard presents the same population figures for the year 1905, but does not add them, thus demonstrating that some of the figures may not be accurate. ${ }^{5}$ In 1920 this author arrives at a total figure for the Outer Provinces of 14.366.054, almost the double of the 1905 figures.

\begin{tabular}{|c|c|c|c|c|c|}
\hline Gewesten (Residencies) & $\begin{array}{c}\text { Number } \\
\text { Regencies }\end{array}$ & Indigenous & Europeans & Other & $\begin{array}{c}\text { Total } \\
\text { population }\end{array}$ \\
\hline Government Atjeh e.o. & 5 & 571.477 & 761 & 9.937 & 582.175 \\
\hline Government West Sumatra & 10 & 1.295 .581 & 2.923 & 9.967 & 1.308 .471 \\
\hline Tapanoeli & 5 & 410.939 & 436 & 1.926 & 413.301 \\
\hline Benkoelen & 5 & 201.315 & 358 & 2.396 & 204.069 \\
\hline Lampong Districts & 4 & 155.080 & 146 & 1.292 & 156.518 \\
\hline Palembang and Djambi & 8 & 783.259 & 678 & 12.417 & 796.354 \\
\hline Eastcoast Sumatra & 7 & 450.941 & 2.667 & 114.809 & 568.417 \\
\hline Riouw e.o. & 7 & 93.315 & 221 & 18.680 & 112.216 \\
\hline Banka e.o. & 1 & 70.853 & 317 & 43.742 & 114.912 \\
\hline Biliton & 1 & 34.181 & 136 & 2.541 & 36.858 \\
\hline West Borneo & 9 & 400.332 & 374 & 50.223 & 450.929 \\
\hline Southeast Borneo & 10 & 772.532 & 1.008 & 9.186 & 782.726 \\
\hline Government Celebes e.o. & 11 & 407.762 & 1.572 & 6.165 & 415.499 \\
\hline Menado & 7 & 428.063 & 1.264 & 7.079 & 436.406 \\
\hline Amboina & 7 & 294.466 & 2.232 & 2.306 & 299.004 \\
\hline Ternate e.o. & 6 & 106.632 & 497 & 1.286 & 108.415 \\
\hline South New Guinea & 1 & 393 & 35 & 59 & 487 \\
\hline Timor e.o. & 4 & 306.469 & 249 & 1.882 & 308.600 \\
\hline Bali and Lombok & 4 & 520.762 & 119 & 2.654 & 523.535 \\
\hline Total & 112 & 7.304 .352 & 15.993 & 298.547 & 7.618 .892 \\
\hline
\end{tabular}

4 Regeeringsalmanak 1910, Grondgebied en Bevolking, 6-8. The abbreviation 'e.o.' means 'and dependencies'. The Government Westcoast Sumatra is divided into two Regencies Padangse Beneden- en Padangse Bovenlanden. Residencies and Governments are divided in Afdelingen, comparable with regencies on Java.

5 Boomgaard, Population Trends, tables 16 and 17, columns 1905. 


\section{APPENDIX 5}

\section{TERRITORIAL DIVISIONS $1932^{6}$}

(Areas in square $\mathrm{Km}, 000$ omitted)

\begin{tabular}{|c|c|c|c|c|c|}
\hline Java and Madoera & Area & & Outer Provinces & Area & \\
\hline Province of West Java & & & Sumatra & & \\
\hline Bantam (R) & 7.9 & & Lampongs (R) & 28.2 & \\
\hline Batavia (R) & 8.1 & & Palembang (R) & 85.9 & \\
\hline Buitenzorg (R) & 11.6 & & Jambi (R) & 44.4 & \\
\hline Priangan (R) & 13.6 & & East Coast $(\mathrm{G})$ & 93.5 & \\
\hline Cheribon (R) & 5.6 & & Benkoelen (R) & 25.8 & \\
\hline \multirow[t]{2}{*}{ Sub-total } & & 46.8 & West Coast (R) & 49.5 & \\
\hline & & & Tapanoeli (R) & 39.4 & \\
\hline Province Central Java & & & Atjeh $(\mathrm{G})$ & 55.5 & \\
\hline Pekalongan (R) & 5.6 & & Sub-total & & 422.2 \\
\hline Semarang $(\mathrm{R})$ & 5.4 & & Sumatran Islands & & \\
\hline Japara-Rembang (R) & 6.0 & & Riouw (R) & 32.3 & \\
\hline Banjoemas (R) & 6.4 & & Banka (R) & 11.7 & \\
\hline Kedoe (R) & 4.6 & & Billiton (AR) & 4.8 & \\
\hline Sub-total & & 28.0 & Sub-total & & 48.8 \\
\hline Government Jogjakarta & & 3.1 & Borneo & & \\
\hline \multirow[t]{2}{*}{ Government Soerakarta } & & 6.0 & West (R) & 147.2 & \\
\hline & & & South and East (R) & 386.6 & \\
\hline Province East Java & & & Sub-total & & 533.8 \\
\hline Soerabaya (R) & 3.5 & & & & \\
\hline Bodjonegoro (R) & 6.8 & & Celebes & & \\
\hline Madioen (R) & 6.0 & & Manado (R) & 90.5 & \\
\hline Kediri (R) & 7.0 & & Celebes (G) & 98.9 & \\
\hline Malang (R) & 5.2 & & Sub-total & & 189.4 \\
\hline Probolinggo (R) & 3.5 & & & & \\
\hline Besoeki (R) & 10.1 & & Moluccas & & 498.4 \\
\hline \multirow[t]{2}{*}{ Sub-total } & & 42.1 & & & \\
\hline & & & Lesser Soenda Islands & & \\
\hline \multirow[t]{3}{*}{ Madoera } & & 5.5 & Timor $(\mathrm{R})$ & 63.5 & \\
\hline & & & Bali and Lombok & 10.5 & \\
\hline & & & Sub-total & & 74.0 \\
\hline Total Java and Madoera & & 131.5 & Total Outer Provinces & & 1766.6 \\
\hline
\end{tabular}

6 Indisch Verslag 1932, Grondgebied (Territory). The letters between brackets have the following meaning: R=Residency; AR= Assistant Residency and G=Government. 


\section{APPENDIX 6}

\section{HOSPITAL BED CAPACITY $1930^{7}$}

\section{Comment}

Most of the figures of this table were found in the Indisch Verslag 1930. For the military hospitals the figures of 1933 were used to arrive at an average capacity of 42 . This was also the case for the other private non-subsidized hospitals. As the three psychiatric hospitals on Java alone had a capacity of 5,800 beds together, it was decided to take all the 14 psychiatric institutions in NI together and subtract the figure of 7,648 from the total capacity of specialized hospitals. By doing so the remaining 50 specialized hospitals had an average capacity that more resembled their real capacity.

\begin{tabular}{lccc}
\hline Category of hospitals & $\begin{array}{c}\text { Number } \\
\text { Hospitals }\end{array}$ & $\begin{array}{c}\text { Total hospital } \\
\text { beds }\end{array}$ & $\begin{array}{c}\text { Average bed } \\
\text { capacity }\end{array}$ \\
\hline Central public hospitals & 3 & 2,642 & 880 \\
Other public hospitals & 78 & 4,312 & 56 \\
Military hospitals & 76 & 3,192 & 42 \\
Hospitals of local councils & 13 & 1,498 & 115 \\
Subsidized Private hospitals & 87 & 5,714 & 63 \\
Non-subsidized Private hospitals & 295 & 27,435 & 93 \\
Specialized hospitals, psychiatry & 14 & 7,648 & 546 \\
Specialized hospitals, other & 50 & 4,923 & 98 \\
\hline Total hospitals & 616 & 57,364 & 93 \\
\hline
\end{tabular}

7 Indisch Verslag 1930, De Sociale Toestand, E. Gezondheidszorg, 382-388 and Indisch Verslag 1933, Ziekeninrichtingen. Aantal en Verpleegden,67-68 (survey of the hospitals and of the number of patients). 


\section{APPENDIX 7}

\section{HOSPITAL FIGURES BRITISH INDIA $1936^{8}$}

\begin{tabular}{|c|c|c|c|c|c|c|c|c|c|}
\hline \multirow[t]{2}{*}{ Province } & \multirow{2}{*}{ Population } & \multicolumn{2}{|l|}{ Area } & \multicolumn{2}{|c|}{ Hospitals } & \multicolumn{2}{|r|}{ Dispensaries } & \multicolumn{2}{|c|}{$\begin{array}{l}\text { Hospitals \& } \\
\text { dispensaries }\end{array}$} \\
\hline & & $\frac{\mathscr{e}}{\ddot{Z}}$ & $\frac{\text { हे }}{\text { है }}$ & $\stackrel{\mathscr{0}}{\ddot{E}}$ & 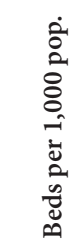 & 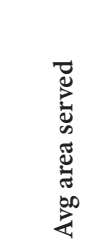 & 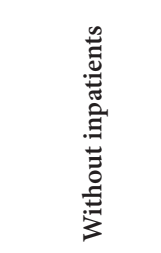 & 吾 & 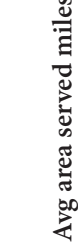 \\
\hline Madras & 46,740 & 142,277 & 334 & 11,134 & 0.24 & 428 & 800 & 1,134 & 126 \\
\hline Bombay & 17,992 & 77,221 & 320 & 7,669 & 0.43 & 241 & 109 & 429 & 180 \\
\hline Bengal & 50,114 & 77,521 & 229 & 9,542 & 0.19 & 3,417 & 1,220 & 1,449 & 64 \\
\hline $\begin{array}{l}\text { United } \\
\text { Provinces }\end{array}$ & 48,409 & 106,248 & 490 & 8,629 & 0.18 & 217 & 107 & 597 & 178 \\
\hline Punjab & 23,581 & 99,265 & 764 & 9,989 & 0.42 & 130 & 124 & 888 & 111 \\
\hline $\begin{array}{l}\text { Central } \\
\text { Provinces }\end{array}$ & 15,508 & 99,920 & 231 & 3,237 & 0.21 & 433 & 93 & 343 & 291 \\
\hline Bihar & 23,676 & 36,877 & 159 & 4,981 & 0.21 & 232 & 369 & 528 & 70 \\
\hline Assam & 9,248 & 67,334 & 95 & 2,175 & 0.24 & 709 & 248 & 324 & 196 \\
\hline Sind & 3,887 & 46,378 & 86 & 1,437 & 0.37 & 538 & 22 & 108 & 429 \\
\hline Orissa & 4,202 & 8,210 & 65 & 1,161 & 0.28 & 126 & 98 & 163 & 50 \\
\hline Delhi & 636 & 673 & 14 & 1,082 & 1.70 & 48 & 10 & 24 & 28 \\
\hline $\begin{array}{l}\text { NW Frontier } \\
\text { Prov. }\end{array}$ & 2,425 & 13,518 & 67 & 1,625 & 0.67 & 202 & 47 & 114 & 118 \\
\hline Baluchistan & 464 & 54,400 & 40 & 714 & 1.54 & 1,360 & 1 & 41 & 1,327 \\
\hline $\begin{array}{l}\text { Ajmer- } \\
\text { Merwara }\end{array}$ & 560 & 2,711 & 8 & 244 & 0.44 & 339 & 2 & 10 & 271 \\
\hline Coorg & 163 & 1,593 & 3 & 174 & 1.07 & 531 & 8 & 11 & 145 \\
\hline Total & 247,605 & 834,146 & 2,905 & 63,793 & 0.26 & 287 & 3,258 & 6,163 & 135 \\
\hline
\end{tabular}

8 E.W.C. Bradfield, An Indian Medical review 1938 (New Delhi, 1938) 


\title{
SOURCES AND LITERATURE
}

\author{
Unpublished Sources
}

\section{The Hague, Nationaal Archief}

- Archive Department of Colonies,1850-1900, accession no. 2.10.02. Inventory numbers 6477-6484, 8350, 8913 and 9028.

Personal archive W.F. Theunissen (1882-1960), accession code 2.21.160.

Inventory numbers 3-4 and 9-10. W.F.Theunissen was director of the psychiatric hospital Soember Porrong during 10 years (1925-1935) and afterwards Chief of the Public Health Service.

- Series Memorandums of transfer (of office), 1852-1962, accession code 2.10.39, Microfiches 40 to 43-1.

- Series mailreports 1869-1950, accession code 2.10.36.02.

Mailreport no. 1262/30.

Memorandum of transfer of office by P.J. van Gulik, Governor of Central Java (June 1930).

\section{Stadsarchief Utrecht}

Collection/Archives/Religion, accession number 73: Generaal deputaatschap voor de zending, code 2.3.2.11, concerning missionary regions

- Inventory no. 456: correspondance about female missionary doctor Dreckmeier concerning conflict and dismissal;

- Inventory number 457: letter on decrease of subsidies and its consequences, 1934-1935;

- Inventory number 458: Building design of a hospital for indigenous patients;

\section{Koninklijk Instituut voor de Tropen, Amsterdam}

- Code no. 05437, Data collected over the period 1931, 1 map 43 x 94 cm coloured, map of private hospitals, psychiatry asylums, eye hospitals, sanatoria in the NI.

- Memories van Overgave, originating from KIT, admission code 2.10.39:

- Inv.no. 547, Resident C.A. Schnitzler (Modjokerto) 3 fiches

- Inv.no. 579, Resident W.Ch. Adriaans, 1931 (Madoera) 1 fiche

- Inv.no. 783, Resident A.I. Spits, 1937 (Westcoast Sumatra) 1 fiche

- Inv.no. 946, Controleur W.A. de Laat de Kanter, 1940 (Benkoelen) 1 fiche

- Inv.no. 1008, Resident B.C.C.M. van Suchtelen, 1933 (SE Borneo) 9 fiches

- Inv.no. 1087, Gouvernor J.L.M. Swaab,1936 (Government Celebes) 3 fiches

- Inv.no. 1218, Resident B.J. Haga, 1937 (Moluccas) 1fiche 


\section{Koninklijke Bibliotheek, The Hague}

- Drawing from land surveyor and draughtsman Jacob van Meurs, Atlas van Hagen, Royal Library volume 4, inv.no. 1049B13_0260.

\section{PERIODICALS AND ANNUAL ACCOUNTS}

- Koloniaal Verslag, Appendix C of the Acts of Parliament, 1890 tot 1929 (Staatsdrukkerij The Hague). Reference: KV

- Verslag van Bestuur en Staat van Nederlandsch-Indië, Suriname en Curaçao. I Nederlandsch-Indië. From 1924 to 1930 the equivalent of the Koloniaal Verslag was published under this heading.

- Indisch Verslag. From 1932 to 1940 the Koloniaal Verslag was published under this heading.

- Regeeringsalmanak voor Nederlandsch-Indië, 1890 tot 1942 (Landsdrukkerij Batavia). In some years it was published in three volumes:

- Grondgebied en Bevolking (Territory and Population)

- Kalender en Personalia (Civil calendar and personal columns)

- Burgerlijke Stand of Adresboek (Registry or Directory)

- Staatsblad van Nederlandsch-Indië, 1890 - 1942. The Statutebook of the Netherlands Indies was published by the Landsdrukkerij, Batavia.

- Bijbladen Staatsblad van Nederlandsch-Indië, 1890 - 1942. The Supplements of the NI Statutebook (Landsdrukkerij Batavia).

- Geneeskundig Tijdschrift voor Nederlandsch-Indië, 1852 - 1942. Medical Review for the Netherlands Indies.

- Nederlands Tijdschrift voor Geneeskunde, 1890 - 1940. Dutch Medical Review. Particularly the articles on the Netherlands Indies.

- Het Ziekenhuis. Monthly Review on Dutch hospitals, 1918 and 1980.

- Mededeelingen Dienst der Volksgezondheid, 1924 - 1939. Bulletin of the Public Health Service. 


\section{BIBLIOGRAPHY}

Aardrijkskundig en Statistisch Woordenboek van Nederlandsch Indië, $1^{\mathrm{e}}$ deel, A-J. Transl.: Geographical and Statistical Dictionary of the NI (Amsterdam 1861).

Aa, A.D. van der, Aardrijkskundig Woordenboek der Nederlanden, $2^{\mathrm{e}}$ deel. Transl.: Geographical Dictionary of the Netherlands (Gorinchem 1839).

Akveld, Leo en E.M. Jacobs, ed., Nationaal Jubileumboek VOC 1602-2002, De Kleurrijke wereld van de VOC Transl.: National Jubilee Issue VOC 1602-2002, The colorful world of the VOC (Bussum 2002).

Allen \& Donnithorne, Western enterprise in Indonesia and Malaya, a study in economic development (London 1956).

Alting, W.A., Resolutie Gouverneur-Generaal van 26 September 1788, "Voorschriften nopens de wijze waarop hospitalen moeten worden ingerigt en beheerd"Transl.: "Regulations of equipment and management of hospitals", in: J.A. van der Chijs ed. Nederlandsch-Indisch Plakkaatboek 1602-1811 (Batavia 1900) 71-74.

Alting, W.A., Resolutie Gouverneur-Generaal van 19 April 1793, "Bepalingen nopens het buitenhospitaal at Batavia van 19 April 1793" in: J.A. van der Chijs ed. Nederlandsch-Indisch Plakkaatboek 1602-1811 (Batavia 1900) 525-526. Transl.: "Regulations with reference to the Outer Hospital at Batavia".

Anderson, Warwick, Colonial Pathologies, American tropical Medicine, Race and Hygiene in the Philippines (London 2006).

Anderson, Warwick, "Immunization and Hygiene in the Colonial Philippines", Journal of the History of Medicine and Allied Science, 62 (2006) 7-8.

Anrooij, Francien van, De koloniale staat 1854-1942. Gids voor het archief van het ministerie van Koloniën. De Indonesische archipel. Transl.: The colonial state 1854-1942. Guide for the archives of the Colonial Department. The Indonesian archipelago (Den Haag 2009).

Arnold, David, Colonizing the Body, State medicine and Epidemic Disease in NineteenthCentury India (London 1993).

Baermann, G., Report 1919-1925 Serdang Doctor Fonds (Medan s.a.).

Barend-van Haeften, Marijke, Oost-Indië gespiegeld, Nicolaas de Graaff, een schrijvend chirurgijn in dienst van de VOC. Transl.: Mirror to the East Indies, Nicolaas de Graaff, a writing surgeon in VOC-service (Zutphen 1992). 
Bartelsman, M. en P.P. Eckhardt, "Geestesziek in Nederlands-Indië - vier psychiatrische syndromen: amok, latah, koro en tropenneurasthenie". Transl.: "Mental ill in the NI - four psychiatric syndromes: amok, latah, koro and tropical neurasthenia" Ned Tijdschr Geneeskd 151 (2007) 2845-2851.

Bauer, J.H. en W.M. Smit, Verslag van het onderzoek naar den tegenwoordigen toestant van het krankzinnigenwezen in het algemeen en van de gestichten en verblijven der krankzinnigen in Nederlandsch-Indië in het bijzonder, met aanwijzing der middelen welke tot verbetering kunnen worden aangewend (Batavia, 1868). Transl.: Report on the situation of institutions for mental diseases and recommendations to improve that situation.

Bergen, Leo van, Van koloniale geneeskunde tot internationale gezondheidszorg, een geschiedenis van honderd jaar Nederlandse Vereniging voor Tropische Geneeskunde (Amsterdam 2007) Transl.: From colonial medicine to international health care, history of 100 years NVTG.

Bergen, Leo van, Een Menslievende en Nationale Taak. Oorlog, kolonialisme en het Rode Kruis in Nederlandsch-Indie 1870-1950 (Soesterberg 2004).

Blécourt, Willem de, F. Huisman en H.v.d. Velden, "De medische markt in Nederland, 1850-1950”, Tijdschrift voor Sociale Geschiedenis, 25 (1999), 361-382.

Bleeker, P., Atlas ichthyologique des Indes orientales (s.a., s.l.).

Blussé, Leonard, "Coen en de stichting van Batavia," in: Anthony Reid ed., Geschiedenis van Indonesië, deel 2 Vroegmoderne geschiedenis (Abcoude 1998).

Blussé, Leonard \& Jaap de Moor, Nederlanders Overzee. De eerste vijftig jaar 1600-1650 (Franeker 1983).

Bonne, C., "De Geneeskunde in Nederlandsch-Indië, Het Geneeskundig Onderwijs", SuidAfrikaans Tydskrif vir Geneeskunde (1941), 437-438.

Bonne, C., "Het Koningin Wilhelmina Instituut voor Lepraonderzoek”, GTNI 75 (1935) 2010.

Bontius, J., De Medicina Indorum (Leiden, 1642).

Boomgaard, Peter, "The development of colonial health care in Java; an exploratory introduction." Bijdragen tot de Taal-, Land- en Volkenkunde, 149 (1993) 77-93.

Boomgaard, Peter, Children of the Colonial State: Population Growth and Economic Development in Java 1795-1880 (Amsterdam 1989).

Boomgaard, Peter, "Smallpox and vaccination on Java, 1780-1860, medical data as a source for demographic history" in: Luyendijk-Elshout, A.M., ed. Dutch Medicine in the Malay Archipelago, 1816-1942 (Amsterdam 1989) 119-131. 
Boomgaard, Peter, “De Welvaartspolitiek in Nederlands-Indië (1900-1942), Spiegel Historiael 22 (1987) 382-387.

Boomgaard, Peter, “The making and unmaking of tropical science, Dutch research on Indonesia, 1600-2000", Bijdragen tot de Taal-, Land- en Volkenkunde (BKI) 162 (2006) 191217.

Boomgaard, P. "Surviving the Slump: Developments in real income during the depression of the 1930s in Indonesia, particularly Java" in: Idem and I. Brown ed., Weathering the Storm, The Economies of SE Asia in the 1930s Depression (Leiden 2000).

Boomgaard, Peter, "Morbidity and Mortality in Java, 1820-1880: Changing Patterns of Disease and Death" in: Norman G. Owen ed., Death and Disease in Southeast Asia, Explorations in Social, Medical and Demographic History (Oxford 1987) 48-70.

Boomgaard, P. and A.J. Gooszen, Changing Economy in Indonesia, Volume 11, Population Trends 1795-1942 (Amsterdam 1991).

Boomgaard, Peter, 'The Living Dead: Leprosy in the Indonesian Archipelago, Seventeenth to Nineteenth centuries', paper for the workshop on Emergent Science and Technology Studies in Southeast Asia, Singapore, January 14-15, 2009.

Bouvy, A.C.N. "De Minahassa en de geneeskunst", Bijdragen tot de Taal-, Land- en Volkenkunde (BKI) 80 (1924).

Bradfield, E.W.C., An Indian Medical Review 1938 (New Delhi 1938).

Brand, J. van den, De Millioenen uit Deli (The Millions from Deli) (Amsterdam s.a.)

Breman, Jan, Koelies, Planters en Koloniale Politiek (Coolies, planters and colonial policy) (Dordrecht 1987).

Brug, P.H. van der, Malaria en Malaise, De VOC in Batavia in de achttiende eeuw (Amsterdam 1994).

Bruijn, Iris, Ship's Surgeons of the Dutch East India Company, Commerce and the Progress of Medicine in the Eighteenth Century (Leiden 2004).

Burg, C.L. van der, De Geneesheer in Nederlandsch Indië (The physician in the NI) Vol. 1-3 (Batavia 1883, 1885).

Burgers, Herman, De Garoeda en de ooievaar. Indonesië van Kolonie tot Nationale Staat (Leiden 2010). Transl.: The Garuda and the stork, Indonesia from Colony to National State. 
Caljé, P.A.J. en J.C. den Hollander, De nieuwste geschiedenis (History of recent times) (Utrecht 2000).

Camps, A. OFM, V. Poels, J. Willemsen, Dutch Missionary Activities. An oral history project (1976-1988).

Changing Economy in Indonesia, a selection of statistical source material from the early $19^{\text {th }}$ century up to 1940, vol. 11 Population Trends 1795-1942, P. Boomgaard ed. (Amsterdam 1991).

Changing Economy in Indonesia, Volume 2, Public Finance 1816-1939, P. Creutzberg ed.

Changing Economy in Indonesia, Volume 12a, General Trade Statistics, 1822-1940, W.L. Korthals Altes ed. (Amsterdam 1991).

Chijs, J.A. van der, Nederlandsch-Indisch Plakkaatboek 1602-1811, vol. XIII (Batavia 1900).

Colenbrander, H.T., Koloniale Geschiedenis, $3^{e}$ Deel, Nederland, de Oost sinds 1816 (Den Haag 1926).

Cribb, Robert, Digital Atlas of Indonesian History (NIAS Press Copenhagen 2010).

Daal, M. van, A. de Knecht-van Eekelen, "Over aetiologie en therapie van tuberculose: het debat in Nederland (1900-1910)", Gewina 15 (1992).

Dane, C., Geschiedenis van de ziekenverpleging (Lochem 1980).

De Gereformeerde Zendingsbond 1901-1961 Nederland-Tanah Toraja, een bronnenpublicatie, Th. Van den End ed. (s.l. 1985).

De Gereformeerde zending in Midden-Java 1859-1931, een bronnenpublicatie, H. Reenders, ed. (Zoetermeer 2001).

De Gereformeerde zending in Midden-Java 1931-1975, een bronnenpublicatie, Chr. G.F. de Jong, ed. (Zoetermeer 1997).

De Nederlandse Zendingsvereniging in West-Java 1858-1963, een bronnenpublicatie, Th. Van den End ed. (Oegstgeest 1991).

De Protestantse Kerk op de Banda-eilanden 1795-1923, een bronnenpublicatie, M. van Selm ed. (Zoetermeer 2004).

Deventer, C. Th. van, “Eereschuld” (Debt of honour), De Gids 63 (1899) 205-252. 
Diemen, A. van, Resoluties van de Gouverneur-Generaal van 5 tot 8 juli 1642, "Statuten van Batavia”. Transl.: "Bylaws of Batavia" in: J.A. van der Chijs ed. Nederlandsch-Indisch Plakkaatboek 1602-1811 (Batavia 1900) 472-594.

Doel, Wim van den, Zo ver de wereld strekt. De geschiedenis van Nederland overzee vanaf 1800 (Amsterdam 2011). Transl.: As far as the world extends, the history of the Netherlands abroad from 1800 .

Driel, B.M. van, “De Sociale Geneeskunde in den Delischen Kring," GTNI 76 (1936) 308. Transl.: Social Medicine in Deli.

Duijvendak, M. and P. Kooij, Sociale Geschiedenis, theorie en thema's (Assen 1992).

Dutch-Asiatic shipping in the $17^{\text {th }}$ and $18^{\text {th }}$ centuries, J.R. Bruijn, F.S. Gaastra and I. Schöffer ed., Rijks Geschiedkundige publicatiën, Grote serie nr. 165 (The Hague, 1979).

Duymaer van Twist, A.J." Verslag van het Zendingshospitaal te Modjowarno over 1909”. Transl.: "Annual Report 1909 of the Missionary Hospital at Modjowarno" GTNI 50 (1910) 789-813.

Ehrlich, P., “Abhandlungen über salvarsan”, Ned Tijdschr Geneeskd 56 (1912) 1396-1398.

Eijkman, C., "Verslag over de onderzoekingen verricht in het Laboratorium voor Pathologische Anatomie en Bacteriologie te Weltevreden, gedurende het jaar 1889", GTNI 30 (1890) 295-335.

Elson, R.E., Village Java under the cultivation system 1830-1870 (Sydney 1994).

Elst, A. van der, A. Walland, "Iets over hospitaalbouw in de keerkringslanden, meer bijzonder met betrekking tot Nederlandsch Oost-Indië" Transl.: "A few remarks on the architecture of hospitals in tropical countries, especially with reference to the NI" GTNI 19 (1879) 157-184.

Fasseur, C., "De Nederlandse koloniën 1795-1914” in: D.P. Blok a.o., ed., Algemene Geschiedenis der Nederlanden 11 (Bussum 1983). Transl.: "The colonies of the Netherlands 1795-1914".

Ferrer, M., Essai sur la présence médicale francaise en Indochine de 1858 a nos jours (Marseille 1972).

Fitzgerald, Rosemary, "Clinical Christianity: The Emergence of Medical Work as a Missionary Strategy in Colonial India, 1800-1914", in: Biswamoy Pati and Mark Harrison (eds.), Health, Medicine and Empire: Perspectives on Colonial India (New Delhi 2001) 67 and 77 . 
Foucault, M. La naissance de la clinique (Paris 1963).

Furnivall, J.S., Netherlands India, A Study of Plural Economy (Amsterdam 1976).

Gardiner, P. and Mayling Oey, "Morbidity and mortality in Java 1880-1940: The evidence of the colonial reports", in: Norman G. Owen, ed., Death and disease in Southeast Asia, Explorations in Social, Medical and Demographic history (Oxford 1987).

Gedenkboek 40 jaar ziekenverpleging Koningin Emma Ziekenhuis (“Tjikini”) Vereeniging voor ziekenverpleging in Nederlandsch-Indië 1895-1935 (Batavia s.a.). Transl.: Memorial volume 40 years nursing Queen Emma Hospital 1895-1935 “Tjikini”.

Geertz, Clifford, Agricultural involution. The process of ecological change in Indonesia (Berkeley 1963).

Gereformeerde Zending op Sumba 1859-1972, een bronnenpublicatie. Transl.: Dutch Reformed Mission on Sumba 1859-1972, Th. Van den End, ed. (Alphen aan den Rijn 1987).

Geschiedenis van de Nederlandse Zending op Zuid-Sulawesi 1852-1966, een bronnenpublicatie. Transl.: History of the Dutch Mission on South Sulawesi 1852-1966, Chr.G.F. de Jong ed. (Alphen aan den Rijn s.a.).

Gijzeman-Rook, Jacomien, De Geschiedenis van de medische zending in NOI, Transl.: The History of the medical mission in the NEI (s.1. 2007).

Gonggryp, G.F.E., Geillustreerde encyclopaedie van Nederlandsch Indië. Transl.: Illustrated encyclopaedia of the NI (Wijk en Aalburg 1992).

Goor, J. van, De Nederlandse Koloniën, Geschiedenis van de Nederlandse expansie 1600-1975 ( $2^{\mathrm{e}}$ herziene druk; Bilthoven 1997) Transl.: The Dutch colonies, History of Dutch expansion 1600-1975.

Gouda, Frances, Discipline versus gentle persuasions in Colonial Public Health: The Rockefeller Foundation's Intensive Rural Hygiene Work in the Netherlands East Indies, 1925-1940 (Amsterdam 2009).

Grijns, G., "Het Geneeskundig Laboratorium te Weltevreden”. Transl. “The medical laboratory at Weltevreden." GTNI 57 (1917) 106-130.

Grijns, G., “Over Polyneuritis Gallinarum I, II, III and IV”, GTNI 41, 49, 50 and 51 (1901, 1909, 1910 and 1911).

Groenhart, Kristine, Mangalaan 27. Een dramatisch leven in Nederlands-Indië. Transl.: Mangalaan 27. A dramatic life in the NI (Amsterdam 2012). 
Groot, K.P., "De medische zending in Nederlandsch-Indië”. GTNI 76 (1936). Transl. “The medical mission in the NI."

Grote Atlas van Nederlands Oost-Indië, Diessen, J.R. van, F.J. Ormeling ed. (Zierikzee 2003).

Haga, J. "Uit de verslagen van den geneeskundige dienst. Eenige Statistische gegevens ontleend aan de civiel geneeskundige jaarverslagen (Ook wel genoemd wetenschappelijke verslagen) en aan de rapporten omtrent besmettelijke ziekten van Java en Madoera over het jaar 1902." GTNI 43 (1903) 694-725 en 743-788. Transl.: "Some Statistical data derived from reports of the civil medical service and from reports on infectious diseases for Java and Madoera."

Haga, J.”'Eenige statistische en andere gegevens over het jaar 1909.” GTNI 51 (1911) 1-109 en 285-401. Transl.: "Some Statistical and other data about the year 1909."

Haga, J., "Civiel Geneeskundige Dienst in Nederlandsch Indië”, Ned Tijdschr Geneeskd (1910).

Haneveld, G.T., "From slave hospital to reliable health care; medical work on the plantations of Sumatra's East coast", in: Luyendijk-Elshout, A.M. ed., Dutch Medicine in the Malay Archipelago 1816-1942 (Amsterdam 1989) 73-85.

Harrison, Mark, Public health in British India: Anglo-Indian preventive medicine 18591914 (Cambridge 1994).

Hartog, A.P. den, “Towards improving public nutrition; nutritional policy in Indonesia before independence", in: Luyendijk-Elshout, A.M. ed., Dutch Medicine in the Malay Archipelago 1816-1942 (Amsterdam 1989) 105-118.

Haver Droeze, J.J., "De geneeskundige dienst bij de Nederlandsch-Oost-Indische Compagnie". Transl.: "The medical service with the VOC." Ned Tijdschr Geneeskd 65 (1921) 2535-2560.

Heijermans, L., "Juiste ziekenhuispolitiek?”. Transl.: "Right hospital policy?” Ned Tijdschr Geneeskd 65 (1921) 81-86.

Heijermans, L., "De distributie der ziekenhuis- en gestichtsbedden”. Transl.:" The distribution of hospital and asylum beds." Ned Tijdschr Geneeskd 69 (1925) 1277-1282.

Henley, David, Fertility, Food and Fever, Population, economy and environment in North and Central Sulawesi, $1600-1930$ (Leiden 2005).

Hesselink, Liesbeth, Healers on the colonial market. Native doctors and midwives in the Dutch East Indies. (Leiden 2011). 
Heteren, G.M. van, "The course in tropical medicine at Amsterdam: 'a case of monopolization”? “, in: Luyendijk-Elshout, A.M. ed., Dutch Medicine in the Malay Archipelago 1816-1942 (Amsterdam 1989) 35-55.

Heydt, J.W., Heydt's Ceylon, being the relevant sections of the Allerneuster Geographisch-und Topographischer Schauplatz von Africa und Ost-Indien (Colombo 1952).

Hofmann, J.W., "Krankzinnigenverpleging in Neêrlandsch-Indië”. Transl.: "Nursing of the insane in the NI." De Indische Gids, staat en letterkundig maandschrift 16 (1894) 981-1003.

Hospitals in the EEC, Organisation and Terminology, Anna Garde ed. Hospital Committee of the European Economic Community (Copenhagen 1978).

Houwaart, E.S., De hygiënisten, Artsen, staat \& volksgezondheid in Nederland 1840-1890. Transl.: The hygienists, doctors, state and public health in the Netherlands. (Groningen 1991).

Houwaart, E.S., "De ontwikkeling van het ziekenhuis in de moderne tijd", in: Techniek als cultuurverschijnsel (Heerlen 1996). Transl.: "The development of the hospital in modern times", in: Technology as phenomenon of culture.

Houwaart, E.S., Medische techniek in Nederland in de twintigste eeuw (Eindhoven 1996). Transl.: Medical technics in the Netherlands in the 20th century.

Houwaart, E.S., "De modernisering van de gezondheidszorg en de geneeskunde in de negentiende eeuw". Transl.: "Modernizing health care and Medicine in the 19th century." in: B.J.M. Aulders, e.a. ed., De huisarts van toen, een historische benadering (Rotterdam 1995). Transl.: The physician in old times, a historical approach.

Hüsken-Nilissen, H.W.M. en D. de Moulin, "De Dienst der Volksgezondheid in Nederlandsch-Indië; een terugblik” Ned Tijdschr Geneeskd 130 (1986) 2356-2360. Transl.: "Public Health Service in NI, retrospective."

Imhof, Arthur E., "From the old mortality pattern to the new: Implications of a radical change from the sixteenth to the twentieth century." Bulletin of the History of Medicine, 59 (1985) 1-29.

Jansen, B.C.P., Het levenswerk van Christiaan Eijkman, 1858-1930 (Haarlem 1959). Transl.: Life achievements of Chr. Eijkman.

Jansse, C.W., "De Bataks als exploitanten van hun eigen gebied.” Transl.: "The Batak People developing their own territory." Koloniaal Tijdschrift 12 (1924) 4.

Jong, J.J.P. de, De waaier van het fortuin, de Nederlanders in Azië en de Indonesische archipel 1595-1950 (Den Haag 2000). Transl.: The wheel of fortune, The Dutch people in Asia and the Indonesian archipelago 
Joost, C.R.N.F. van, "De taak van het sanatorium in den strijd tegen tuberculose”. Transl.: "the function of the sanatorium fighting tuberculosis." GTNI 77 (1937) 2863-2890.

Kampen, Anthony van, Een kwestie van macht (Bussum 1975). Transl.: A power game.

Kappelhof, Ton, “Zending en missie in Nederlands-Indië 1798-1960” in: De Indische school (Lessen Godsdienst en Levensbeschouwing (s.l., s.a.). Transl.: "Protestant and Roman Catholic Mission in the NI 1798-1960."

Kartini, Raden Adjeng, Door duisternis tot licht. Gedachten over en voor het Javaansche Volk. Transl.: From the dark to the light. Thoughts about the Javanese people. ('s Gravenhage 1912).

Kerkhoff, A.H.M., "The organization of the military and civil medical service in the nineteenth century", in: Luyendijk-Elshout, A.M., ed., Dutch Medicine in the Malay Archipelago, 1816-1842 (Amsterdam 1989) 9-24.

Ketel, A.P. ,1894-1934, Veertig jaren Medische Zending, Zendingsziekenhuis te Modjowarno (Soerabaja 1935). Transl.: Forty years of medical mission Modjowarno.

Kits van Waveren, E., “De artsenpositie in Indonesië.” Ned Tijdschr Geneeskd 91 (1947) 44-51. Transl.: "The situation of physicians in Indonesia."

Knecht, A. de, van Eekelen, “Tropische geneeskunde in Nederland en koloniale geneeskunde in Nederlands-Indië." Transl.: "Tropical medicine in the Netherlands and colonial medicine in the NI." Tijdschrift voor Geschiedenis 105 (1992).

Knecht, A. de, van Eekelen, “The interaction of western and tropical medicine”, in: Luyendijk-Elshout, A.M. ed., Dutch Medicine in the Malay Archipelago 1816-1942 (Amsterdam 1989) 57-71.

Koelieordonnantie. Transl.: The Coolie Ordinance. Indisch Staatsblad 138 (Decision Governor-General of $13^{\text {th }}$ July 1889) and Indisch Staatsblad 78 (Decision Governor-General of $11^{\text {th }}$ March 1898).

Kousbroek, Rudy, Terug naar Negri Pan Erkoms. (Amsterdam 1995). Transl.: Returning to the country of origin.

Kouwenaar, W., "Indië vóór de oorlog, geneeskundige voorzieningen op Sumatra’s Oostkust" Transl.: "The Indies before the war, medical facilities on the East Coast of Sumatra." Ned Tijdschr Geneeskd 92 (1948) 1293-1300.

Kouwenaar, W., “De gezondheidszorg ter Oostkust van Sumatra.” GTNI 76 (1936) 286. Transl.: "Health care on the East Coast of Sumatra." 
Kuyvenhoven, J.V. en J.F. Broekmans, "Honderd jaar Koninklijke Nederlandse Centrale Vereniging tot bestrijding der Tuberculose (KNCV)" Ned Tijdschr Geneeskd 147 (2003) 1869-1874. Transl.: "Centennial Royal Dutch Central Association to combat Tuberculosis."

Kumar, Ann, "A Swedish view of Batavia in 1783: Hornstedt's Letters." Archipel 37 (1989).

Langen, C.D. de, "Indië vóór de oorlog, Het geneeskundig onderwijs in Indonesië.” Ned Tijdschr Geneeskd 92 (1948) 1582-1588. Transl.: "The Indies before the war, medical education in Indonesia."

Leuftink, Arnold E., Harde Heelmeesters. Zeelieden en hun dokters in de $18^{e}$ eeuw. Transl.: Tough Surgeons, sailors and their physicians in the 18th century (Zutphen 1991).

Lieburg, M.J. van, Het Coolsingelziekenhuis te Rotterdam (1839-1900). De ontwikkeling van een stedelijk ziekenhuis in de negentiende eeuw. Transl.: The Coolsingel hospital at Rotterdam (1839-1900). The development of an urban hospital in the 19th century (Amsterdam 1986).

Lieburg, M.J. van, "De tweede geneeskundige stand (1818-1865). Een bijdrage tot de geschiedenis van het medisch beroep in Nederland" Transl.: "The second medical rank (1818-1865). A contribution to the history of the medical profession in the Netherlands." Tijdschrift voor Geschiedenis 3 (1983) 433-453.

Lindblad, J. Thomas, “The late colonial state and economic expansion, 1900-1930s, in: Howard Dick ed., The Emergence of a National State (Leiden 2002) 111-152.

Loghem, J.J. van, "Brieven uit Indië IV, het pathologisch Laboratorium te Medan (Deli, Sumatra)". Transl.: "Letters from the Indies IV, the pathological Laboratory at Medan." Ned Tijdschr Geneeskd 53 (1909) 413-416.

Loghem, J.J. van, “Brieven uit Indië I, het pestvraagstuk in Nederlandsch-Indië”. Transl.: "Letters from the Indies I, the plague in the NI." Ned Tijdschr Geneeskd 53 (1909) 44-51.

Loghem, J.J. van "Denkbare samenwerking van suikerondernemingen op hygiënisch en geneeskundig gebied”, Archief voor de Suikerindustrie in Nederlandsch Indië (1920). Transl.: "Options for cooperation of sugar mills in the field of hygiene and medicine."

Luinenberg, O., Onze zendingsvelden, Java Transl.: Our mission fields (Oegstgeest z.j.)

Lykles, S., Verslag omtrent het Gouvernements Krankzinnigengesticht te Lawang (Residentie Pasoeroean) vanaf de opening benevens een overzicht van de wordingsgeschiedenis daarvan (Batavia 1906). Transl.: Report on the Psychiatric hospital at Lawang from its opening and a survey of its history.

Mak, G., De eeuw van mijn vader (Amsterdam 2000). Transl.: My father's century. Manderson, Leonore, Sickness and the State, Health and Illness in Colonial Malaya, 18701940 (Cambridge 1996) 63-65. 
Manderson, Leonore, Sickness and the State, Health and Illness in Colonial Malaya, 18701940 (Cambridge 1996) 63-65.

Marr, David G., "Vietnamese Attitudes Regarding Illness and Healing", in: Death and Disease in Southeast Asia, Explorations in Social, Medical and Demographic History, ed. by Norman G. Owen (Oxford 1987) 178-179.

Menke, H.E., e.a., "Bijdragen van Nederland en zijn Koloniën aan de kennis over de oorzaak van lepra in de 19e eeuw". Ned Tijdschr Geneeskd 151 (2007) 825-830. Transl.: "Contributions of the Netherlands and its Colonies to the knowledge of the causes of leprosy in the $19^{\text {th }}$ century."

Mesters, Han, "J.L. Hydrick in the Netherlands Indies, an American view of Dutch public health policy", in: P. Boomgaard, R. Sciortino and I. Smith ed., Health care in Java, Past and Present (Leiden 1996).

Monnais-Rousselot, Laurence, Médecine et colonisation, l'aventure indochinoise 1860-1939 (Paris 1999).

Moon, Suzanne, Technology and Ethical Idealism, a History of Development in the Netherlands East Indies (Leiden 2007).

Moor, C.E. de, "Sanitaire organisatie en landbouwindustrie in Nederlandsch-Indië". Transl.: "Sanitary organization and agriculture in the NI." Ned Tijdschr Geneeskd 74 (1930) 188-192.

Moor, J.A. de, "An extra ration of gin for the troops; the army doctor and colonial warfare in the Archipelago, 1830-1880", in: Luyendijk-Elshout, A.M. ed., Dutch Medicine in the Malay Archipelago 1816-1942 (Amsterdam 1989)133- 151.

Mossel, J., Resolutie Gouverneur-Generaal van 7 December 1751, "Reglement voor het Moorsche hospital bij het fort Jakatra" in: J.A. van der Chijs ed. Nederlandsch-Indisch Plakkaatboek 1602-1811 (Batavia 1900) 114-118. Transl.: "Regulations for the Moorish hospital at the fortress Jakatra."

Moulin, D., “Teaching of medicine in the Dutch East Indies” in: Luyendijk-Elshout, A.M. ed. Dutch Medicine in the Malay Archipelago 1816-1942 (Amsterdam 1989) 25- 33.

Mulock Houwer, A.W., "De bestrijding der blindheid in Nederlandsch-Indië, in het bijzonder op Java”, GTNI 80 (1940) 2007. Transl.: Combating blindness in NI, especially on Java.

Muskens, L.J.J., "Specialistische ziekenhuizen en de onvermijdelijk geworden specialistische opleiding." Transl.: "Specialized hospitals and the inevitable training of medical specialists." Ned Tijdschr Geneeskd 65 (1921) 2574-2580. 
Mushtaq, M.U., "Public health in British India. A brief account of the history of medical services and disease prevention in colonial India." Indian Journal of Community Medicine 34 (2009) 6-14.

Niemeijer, H.E., Batavia, een koloniale samenleving in de 17 e eeuw (Amersfoort 2005). Transl.: Batavia, a colonial society in the 17th century.

Niet, J. de, Ziekentroosters op de pastorale markt, 1550-1880 (Rotterdam 2006).

Nieuhof, Johannes, Gedenkwaerdige zee en lantreize door de voornaemste landschappen van West en Oostindien (Amsterdam 1682).

Offringa, J., "Indië vóór de oorlog, geneeskundige hulp aan de Javaanse bevolking door middel van hulpziekenhuizen en policlinieken"Transl.: “The Indies before the war, medical assistance to the Javanese population by auxiliary hospitals and outpatient clinics" Ned Tijdschr Geneeskd (1948) 2138-2146.

Onderzoek naar de mindere welvaart der inlandsche bevolking op Java en Madoera, delen I-XII. Transl.: Exploration of the causes of the decreasing standards of living of the indigenous population of Java and Madoera (Landsdrukkerij Batavia 1905-1914).

Peacock, J. and E. Jung, "A century of helping shape a moderate Muslim democracy", NewsObserver.com, Jan.31, 2012.

Penris, P.W.L., "Indië vóór de oorlog, het aandeel der landbouwondernemingen op Java in de geneeskundige voorzieningen van Nederlandsch Indië” Ned Tijdschr Geneeskd 92 (1948) 1438-1445. Transl.:" The NI before the war, the participation of agricultural companies on Java in the medical facilities of the NI".

Penris, P.W.L., De geneeskundige verzorging van arbeiders bij landbouwkundige ondernemingen op Java (Amsterdam 1930). Transl.: The medical care of labourers with Agricultural Enterprises on Java.

Peverelli, P., De zorg voor de Volksgezondheid in Nederlandsch-Indië Transl.: The care of public health in the NI ('s Gravenhage, z.j.).

Pols, H., "The development of psychiatry in Indonesia: From colonial to modern times", International Review of Psychiatry 18 (2006) 363-370.

Porter, Roy, The greatest benefit to mankind, a medical history of humanity from antiquity to the present (London, 1999).

Querido, A., Godshuizen en Gasthuizen, een geschiedenis van de ziekenverpleging in WestEuropa Transl.: Religious houses and Alms houses, a history of nursing in Western Europe (Lochem 1974). 
Rapport der Commissie tot voorbereiding eener reorganisatie van den Burgerlijken Geneeskundigen Dienst. Gouvernement Nederlandsch Indië (Batavia 1908).

"Regelen voor de toekenning van subsidiën uit's Lands Kas ten behoeve van particuliere Inlandsche ziekenhuizen en hulpziekenhuizen" Staatsblad van Nederlandsch Indië 276 (13 juni 1906). Transl.: "Regulations for the attribution of subsidies from the Treasury for the benefit of private indigenous hospitals and auxiliary hospitals".

Rhemrev, J.L.T., Rapport van het mij bij Gouvernements Besluit van 24 Mei 1903 no.19 opgedragen onderzoek Transl.: Report on my Government commissioned explorations (Opgenomen in Jan Breman, Koelies).

Rijnberg, Theo F., ’s Lands Plantentuin, Buitenzorg 1817-1992 (Enschede 1992).

Römer, L.S.A.M. von, Historische Schetsen. Een inleiding tot het vierde congres der Far Eastern Association of Tropical Medicine (Batavia 1921). Transl.: Historical sketches. An introductory to the $4^{\text {th }}$ Congress of the FEATM.

Rosenberg, Charles E., The Care of Strangers, the Rise of America's Hospital System (Baltimore 1995).

Schadee, W.H.M., Geschiedenis van Sumatra's Oostkust, deel II. Transl.: History of Sumatra East Coast (Amsterdam 1918).

Schoute, D., "De geneeskunde in Nederlandsch-Indië gedurende de negentiende eeuw" Transl.: "Medicine in the NI during the 19th century" GTNI 74 (1934) and 75 (1935).

Schoute, D., Occidental therapeutics in the Netherlands East Indies during three centuries of Netherlands Settlement, 1600-1900 (Batavia 1937).

Schoute, D., De Geneeskunde in den dienst der Oost-Indische Compagnie in NederlandschIndië. Transl.: Medicine of the Dutch East-India Company (Amsterdam 1929).

Schulte Nordholt, H.C.G., Indonesië na Soeharto, Reformasi en Restauratie (Amsterdam 2008).

Sciortino, Rosalia, The care-takers of cure: a study of health centre nurses in rural Central Java (Amsterdam 1992).

Sciortino, Rosalia, “The multifariousness of nursing in the Netherlands Indies” in: P. Boomgaard, R. Sciortino and I. Smith ed., Health care in Java, Past and Present (Leiden 1996).

Sciortino, Rosalia, "Rural nurses and doctors, The discrepancy between Western Concepts and Javanese practices", in: P. Boomgaard, R. Sciortino and I. Smith ed., Health care in Java, Past and Present (Leiden 1996). 
Sherwood, Joan, Infection of the Innocents: Wet nurses, Infants, and Syphilis in France, 1780 -1900 (Montreal 2010).

Simmons, James Stevens a.o., Global Epidemiology, a Geography of Disease and Sanitation vol. 1, part 1, India and the Far East (London 1944).

Simons, R.D.G.Ph., "De geneeskundige taakverdeeling in Indië kort voor en terstond na den oorlog", Ned Tijdschr Geneeskd 90 (1946) 870-873. Transl.: "The medical allocation of functions in the NI shortly before and immediately after WWII."

Soedjatmoko, Sejarah Rumah Sakit Kristen Modjowarno (Surabaya 1995). A memorial book at the centennial of the hospital in 1994.

Sokhieng Au, Mixed Medicines, Health and Culture in French Colonial Cambodia (Chicago 2012).

Stevens, Harm, De Nederlands-Indische geschiedenis van de negentiende en de twintigste eeuw (Amsterdam 2003).

Stibbe, F.S., "Kritiek op het Rapport der Commissie tot Voorbereiding eener Reorganisatie van den Burgerlijken Geneeskundigen Dienst, Verloskundige praktijk in de dessa", GTNI 49 (1909) 385-415.Transl.: Criticizing the Report of the Reorganization Commission on midwifery in the desa.

Stoler, Ann Laura, Capitalism and Confrontation in Sumatra's Plantation belt, 1870-1979 (New Haven 1985).

“Summier Ziekenrapport van Nederlandsch-Indië over het jaar 1890.” Transl.: “Summary Review on patients of the year 1890" GTNI 31 (1891) 156-216.

Sutherland, Heather, "Slaven en slavenhandel", in: Anthony Reid ed., Geschiedenis van Indonesië, Land, volk en cultuur. 2. Vroegmoderne geschiedenis. Transl.: History of Indonesia, Land, nation and culture. 2. Early modern history (Abcoude 1998) 246-248.

Swaving, C., "Batavia's sanitaire geschiedenis onder het bestuur van de Oost-Indische Maatschappij."” Ned Tijdschr Geneeskd 22 (1878) 1-210. Transl.: “The sanitary history of Batavia under VOC rule."

Swaving, C., "Een woord over de zaak van de plaatsing van het krankzinnigengesticht te Buitenzorg op Java." Transl.: "Comment on situating the Asylum for insane at Buitenzorg" Ned Tijdschr Geneeskd 18 (1874) 45-55; 61-74; 77-87.

Swaving, C.,"Het Centraal Krankzinnigengesticht te Buitenzorg" GTNI 20 (1880) 337- 379. Transl.: "The Central Asylum for insane at Buitenzorg." 
Sysling, Fenneke, The Archipelago of Difference, Physical anthropology in the Netherlands Indies 1890-1960 (Amsterdam 2013).

Székely-Lulofs, M.H., Rubber. Roman uit Deli (Amsterdam 1992).

Tijssen, J., "Oogheelkunde in den kampong en in de hoeta". Transl.: "Ophthalmology in the kampong and in the hoeta." Ned Tijdschr Geneeskd 77 (1933) 3702-3708.

Tulkens, Joyce, Jan Pieterszoon Coen, bedwinger van Indië. Transl.: J.P. Coen, conqueror of the Indies (Kampen 2007).

Uragoda, C.G. and K.D. Paranavitana, "The seventeenth-century Dutch hospital in Colombo", Medical History 29 (1985)182-192.

Valentijn, François, Beschrijvinge van Oud en Nieuw Oostindiën vol. II 20, 124 en vol. III, 269-289. Transl.: Description of the Old and New East Indies (Dordrecht 1724).

Veghel, Gerrit van, "De medische markt en de historiografische heroriëntatie in de medische geschiedschrijving" Transl.: “The medical market and the reorientation in medical historiography." in: Willem de Blécourt en Gerrit van Veghel ed., De medische markt. Focaal $21(1993) 9-42$.

Velde, E. van de, "Het Hospitaalwezen op Sumatra’s Oostkust" Het Ziekenhuis 9, 10 en 11(1918). Transl.:" The hospital system on the Eastcoast of Sumatra."

Velden, Henk van der, Financiële toegankelijkheid tot gezondheidszorg in Nederland, 18501941 (Amsterdam 1993) Transl.: Financial accessibility of health care in the Netherlands.

Velden, Henk van der, "Groot of klein: de opbouw van het Nederlandse ziekenhuiswezen, 1890-1950." Transl.: "Large or small: the structure of the Dutch hospital system, 1850-1950." Tijdschrift voor Sociale Geschiedenis 25 (1999) 407-424.

Verdoorn, J.A., Het Gezondheidswezen te Amsterdam in de $19^{e}$ eeuw. Transl.: The health care system at Amsterdam in the $19^{\text {th }}$ century (Nijmegen 1981).

Verhave, Jan Peter, "Malaria: epidemiology and immunity in the Malay Archipelago", in: Luyendijk-Elshout, A.M. ed., Dutch Medicine in the Malay Archipelago 1816-1942 (Amsterdam 1989) 86-104.

Verhave, Jan Peter, The Moses of malaria, Nicolaas H. Swellengrebel (1885-1970), abroad and at home (Rotterdam 2011).

Verploegh Chassé, W., 43e Jaarverslag Soerabajasche Ziekenverpleging (Soerabaja 1940).

"Verzorging van geestelijke behoeften en sociale welvaartszorg uit Inlandschen Kring." 
Transl.: "Care of psychological needs and social welfare in indigenous society." in: Indisch Verslag 1930, 35-70.

Vogel, Morris J., The Invention of the Modern Hospital, Boston 1870-1930 (Chicago 1985).

Vorstman, A.H., "Eenige opmerkingen betreffende het verloskundige vraagstuk in onze Oost-Indische koloniën." Transl.: "Some remarks on the question of obstetrics in the colony of the East Indies" Ned Tijdschr Geneeskd 54 (1910) 1552-1557.

Vos, G.W.F. de, Indische bouw-hygiëne. Proeve van een toepassing van de gezondheidsleer bij het bouwen in Nederlandsch-Indië. Transl.: The hygienics of building in the Indies. The utilization of health principles in building in the Indies. (Batavia 1892).

Waardt, Hans de, Mending minds, a cultural history of Dutch academic psychiatry (Rotterdam 2005).

Wal, S.L. van der, "Nederland en Nederlandsch-Indië 1914-1942", in: Algemene Geschiedenis der Nederlanden 14 (Bussum 1979).

Warmenhoven, A.A.J. "De opleiding van Nederlandse bestuursambtenaren in Indonesië.'Transl.: “The training of Dutch civil servants in Indonesia”, in: Wal, S.L. van der, ed. Besturen overzee, Herinneringen van oud-ambtenaren bij het binnenlands bestuur in Nederlandsch-Indië (Franeker 1977).

Wertheim, W.F., "Conditions in Sugar Estates in Colonial Java. Comparisons with Deli." Journal of Southeast Asian Studies, 24 (September 1993).

Wijkhuijs, Arlien, De medische zending in Nederlands Oost-Indië gedurende het begin van de $20^{\mathrm{e}}$ eeuw. Transl.: The medical mission in the NEI during the beginning of the 20th century (Scriptie Geschiedenis der Geneeskunde RUL, Leiden 2006).

Wijn, P., "Verslag der Ophtalmologische kliniek en polikliniek te Ngawi over 1904". GTNI 45 (1905) 723-728. Transl.: "Report of the Ophthalomological hospital and outpatient clinic at Ngawi in 1904."

Wijnmalen, T.C.L., Statistisch overzicht van Nederlandsch Oost-Indië, Indeeling der Europeesche en met deze gelijkgestelde bevolking naar de beroepen en bedrijven in 1884 (s.a., s.l.).

Willemsen, Jan, Van tentoonstelling tot wereldorganisatie. De geschiedenis van de stichtingen Memisa en Medicus Mundi Nederland, 1925-1995 (Nijmegen 1996). Transl.: From exhibition to world organization. The history of the foundations Memisa and Medicus Mundi Nederland, 1925-1995.

Willemsen, J.Th., Academische Leken Missie Actie 1947-1967. Transl.: Academic Laymen mission action 1947-1967 (Nijmegen 1990). 
Winckel, Ch.W.F., "Ziekenfondsen in Nederlandsch Indië.” Transl.: "Sick Funds in the NI" Ned Tijdschr Geneeskd 77 (1933)3275-3283.

Winckel, Ch.W.F., "Indië vóór de oorlog, de Dienst der Volksgezondheid in Nederlandsch Indië.” Ned Tijdschr Geneeskd 92 (1948)1206-1216. Transl.: “The Indies before the war, the Public Health Service in the NI."

Witjes, Ben, Indonesië (Zutphen 1990).

Wolff, S.W. de, "Het sanatoriumvraagstuk in Indië" Transl.: “The sanatorium question in the Indies" GTNI 77 (1937) 2836-2863.

Wøller, Johan, Als Officier van Gezondheid naar Nederlands-Indië (Utrecht s.a.).

Worboys, M, "British colonial medicine and tropical imperialism: a comparative perspective", in: Luyendijk-Elshout, A.M. ed., Dutch Medicine in the Malay Archipelago 1816-1942 (Amsterdam 1989) 153-167.

Wortmann, J.L.C., "De ontwikkeling van het ziekenhuiswezen.” Transl.: “The development of the hospital system" Ned Tijdschr Geneeskd 65 (1921) 497- 506.

Wortmann, J.L.C., "De kleine ziekenhuizen. Transl.: “The small hospitals" Ned Tijdschr Geneeskd 72 (1928) 4050-4056.

Wortmann, J.L.C., De Amsterdamsche Ziekenhuizen (Lochem, 1932).

Wulfften Palthe, P.M. van, "Krankzinnigenverzorging in Nederlandsch-Indië" Transl.: "Care of the insane in the NI." GTNI 77 (1937)1266-1280.

Zandvliet, Kees, De Nederlandse ontmoeting met Azië 1600-1950 (Amsterdam, Zwolle 2003). Transl.: The Dutch encounter with Asia 1600-1950.

Zondervan, S., "De positie van het categorale ziekenhuis." Transl.: "The position of the specialized hospital", Het Ziekenhuis 9 (1980).

Zondervan, S., "De strijd om het gespecialiseerde ziekenhuis.” Transl.: “The fight to maintain the specialized hospital." Het Ziekenhuis 20 (1980).

Zondervan, S., De ziekenhuizen van Nederlands Oost-Indië in de negentiende eeuw. (Working paper Master Course Medical History of the VU/Vumc 2004/2005).

Zondervan, S., De ziekenhuizen in Nederland en Indonesië in de $19^{e}$ eeuw, een vergelijking van de ontwikkelingen (scriptie Vrije Universiteit Amsterdam, 2006). 


\section{CURRICULUM VITAE}

Sjoerd Zondervan (1941) was born in Stiens, Province of Friesland. He attended the Dutch High School (HBS) in Leeuwarden and studied economics at the Vrije Universiteit, Amsterdam. He graduated in 1967.

In the Ivory Coast (West Africa), he worked as District accountant for the Methodist Missionary Society in London.

In 1970, he received an appointment with the National Mental Health Organization of the Netherlands, where he was charged with the economic management.

In 1975, he was appointed as economic director of the Royal Netherlands Eye Hospital at Utrecht and in 1982 as general director of the Valeriuskliniek, Amsterdam.

He concluded his professional career as chairman of the board of directors of the Psychiatric Centre Amsterdam. In between he assisted the Netherlands Management Cooperation Programme (PUM), a joint venture of the Dutch Association of Employers and the Ministry of Foreign Affairs and was sent as senior expert on several missions.

After his retirement he studied History at the Vrije Universiteit and was graduated in 2006.

Sjoerd Zondervan is married to Jelly Rienstra. They have three children and three grandchildren. 


\section{LIST OF FIGURES, TABLES AND MAPS}

\section{Figures}

The old Dutch Hospital at Colombo

page

City Hospital Batavia about 1700

Treatments 1895 - 1899

The outpatient clinic of Taroetoeng (West Sumatra) 94

Medical personnel 1890 - $1910 \quad 102$

The military hospital at Soerabaja 105

Use of hospital beds in the main cities of Java 108

$\begin{array}{ll}\text { Civil Hospital Menado } & 109\end{array}$

Diaconessenhuis Tjikini in $1896 \quad 113$

$\begin{array}{ll}\text { Operating theatre Ombilin Mine } & 118\end{array}$

The Leprosy village at Laoe Si Momo 122

Sanatorium Soekaboemi (West Java) 125

Export before, during and after war time (in million f) $\quad 140$

Parc Vaccinogene and Institute Pasteur at Bandoeng 147

Professional Health Care workers Netherlands Indies 1910 and 1930

Some diseases and mortality $1930 \quad 155$

Location military hospitals $1930 \quad 159$

The new Central Government Hospital at Salemba 163

Statistics CGHs of Batavia, Semarang and Soerabaja 1910 and $1930 \quad 164$

$\begin{array}{ll}\text { Provincial hospital at Tegal } & 167\end{array}$

Division company hospitals $1930 \quad 168$

Health facilities in the Sugar Industry on Java in 1929

Hospital 'Onder de Bogen’ $\quad 172$

Charity facilities managed by other organizations 176

Leprosy village at Kelet, $1920 \quad 177$

Opening Sanatorium Patjet near Tjiandjoer, $1919 \quad 181$

Psychiatric Hospital at Lawang $1912 \quad 183$

Psychiatric facilities $1930 \quad 184$

Staff Public Health Service in 1936

Disease type and \% admissions in 1938 in 167 hospitals 200

Roman Catholic hospital Palembang $\quad 209$

Clinic Sugar Company Ngandjoek (1930) 213

Categories of civil hospitals, 1940 


\section{Tables}

Vaccinations on Java and Madoera 1860-1890

page

Military hospitals in 1867

Indigenous Hospitals 1877

Hospital situation NI about 1890 (military hospitals not included)

Military hospitals 1890

Number of hospitals 1890 and 1910

103

Public expenditure 1910 and 1930 (in million $f$ )

128

Reported hospital admissions 1910 - 1930

139

Mortality 1910- 1930 in the provinces of Java

154

Type of hospitals by year

155

Statistics of all Government Civil Hospitals 1930

160

Statistics of some well-known missionary hospitals 1930

165

NI Government Budget 1910 - 1939 (million $f$ )

173

Admissions Diaconessenhuis 1931 per specialist

198

Diseases treated by Modjowarno Mission Hospital, 1933

Annual account 1933 Modjowarno (summarized)

Regional distribution general missionary hospitals 1940

Distribution of NI hospitals 1940

Estimated hospital capacity 1940

Hospital ratios for regions with similar area size

Hospital ratios for regions with similar population size

Two regions compared: Djokjakarta and Eastcoast Sumatra

Distribution of hospitals and beds, related to areas and population

\section{Maps}

Hospitals archipelago 1790 48

Hospitals archipelago 1890

Hospitals Java 1890

Hospitals missionary organizations 1940 


\section{GLOSSARY}

Adat

Atap

Bale-bale

Benteng

Bouw

Beras

Boedelmeesters

Chirurgijn

Desa, dessa

Doekoen

Doekoen baji

Doekoen mata

Dokter djawa

Fabryck

Gasthuis

Heeren XVII

Hilir

Hoeloe

Hospitalier

Intermitteerende koorts

Kampong

Koelie

Koopman

Kota

Krankbezoeker

Landschap

Mandoer

Mantri

Mantri nurse

Mantri tjatjar

Mas

Moeara

Ommelanden

Paal

Padi
Custom, tradition

Roof covering of dry palm leaves

Indonesian couch, made of bamboo

Fortress

Area measure 1 Bouw $=0.7$ ha

Husked rice

Executive estate administrators

Barbers, trained to perform simple surgery

A village or a rural settlement in Indonesia

Traditional healer

Indigenous midwife

Indigenous eye doctor

Indigenous doctor

Head of craftsmen, architect

Charity institution caring poor sick people

17 governors who were in charge of the Dutch East India Company

Downstream part of a river

Upstream part of a river

Chief surgeon in charge

Fevers that accompanied malaria attacks

An enclosed gathering of houses, a small village or a quarter of a town

Indigenous labourer

Merchant

The main city of a district or province

Hospital employee, who visits patients

Area, chiefdom

Headman or supervisor of a Group workmen,

Head, supervisor

Indigenous nurse

Indigenous vaccinator

Member of lower Javanese nobility

River estuary

The outskirts of Batavia

Distance of $1.5 \mathrm{~km}$

Unhusked rice 


$\begin{array}{ll}\text { Pasangrahan } & \text { Indigenous lodging for civil servants } \\ \text { Pasar } & \text { Market place } \\ \text { Paseban } & \text { Ancient rest house, the king's hearing place } \\ \text { Pendoppo } & \text { Open, roofed hall } \\ \text { Pesantren } & \text { Islamic boardingschool, especially for Koran education } \\ \text { Pikul } & \text { Weight of } 60 \mathrm{~kg} \\ \text { Pradjoerit } & \text { Indigenous soldier on Java, escort of civil servants or guarding } \\ & \text { public buildings } \\ \text { Raden } & \text { Title of a member of Javanese nobility } \\ \text { Radja } & \text { Javanese prince } \\ \text { Reduit } & \text { Fortified structure such as a citadel } \\ \text { Rumah Sakit } & \text { Hospital } \\ \text { Sawa, sawah } & \text { Piece of land with low lime walls to grow rice } \\ \text { Schaftbaas, schaftwyf } & \text { Male, female housekeeper } \\ \text { Stadsverband } & \text { City Dressing Station, hospital in a main city } \\ \text { Toean } & \text { Mister } \\ \text { Toekang } & \text { Craftsman } \\ \text { Toko } & \text { Malay for shop } \\ \text { Totok } & \text { European newcomer in NI } \\ \text { Vrijburgher } & \text { Former VOC employee, permitted to settle on VOC territory } \\ \text { Ziekentrooster } & \text { Pastoral function to comfort patients } \\ \end{array}$




\section{ABBREVIATIONS}

$\mathrm{BB}$

BGD

Bijblad IS

BKI

CBZ

$\mathrm{CCH}$

CMS

DVG

GB

GBZ

$\mathrm{GCH}$

GG

GTNI

IEV

IS

$\mathrm{KB}$

KIT

KITLV

KPM

KUN

KV

MGD

MMS

NA

NI
Binnenlands Bestuur (Civil Service)

Burgerlijke Geneeskundige Dienst (Civil Medical Service)

Appendix to Indisch Staatsblad (Appendix IS)

Bijdragen Taal-, Land-en Volkenkunde (Journal of the

Humanities and Social Sciences of Southeast Asia and

Oceania)

Centrale Burgerlijke Ziekeninrichting (Central Civil Hospital)

Central Civil Hospital

Civil Medical Service

Dienst Volksgezondheid (Public Health Service)

Gouvernements Besluit (Government Decree)

Gouvernements Burgerlijke Ziekeninrichting (Government Civil Hospital)

Government Civil Hospital

Gouverneur-Generaal van Nederlandsch-Indië (Governor-

General Netherlands Indies)

Geneeskundig Tijdschrift voor Nederlandsch-Indië (Medical

Review Netherlands Indies)

Indo-Europeesch Verbond (Indo-European League)

Indisch Staatsblad (Statutebook of the Netherlands Indies)

Koninklijke Bibliotheek at The Hague (Royal Library)

Koninklijk Instituut voor de Tropen at Amsterdam (Royal Tropical Institute)

Koninklijk Instituut voor Taal-, Land en Volkenkunde at Leiden

(Royal Netherlands Institute of Southeast Asian and Caribbean Studies)

Koninklijke Pakketvaart Maatschappij (Royal Cy. For Package Transport)

Katholieke Universiteit Nijmegen (Nijmegen University)

Koloniaal Verslag (Colonial Report, Appendix to Proceedings Houses of Parliament)

Militaire Geneeskundige Dienst (Military Medical Service)

Military Medical Service

Nationaal Archief at The Hague (National Archives of the Netherlands)

Nederlands-Indië (Netherlands Indies) 
NIAS

Ned Tijdschr Geneeskd.

NVTG

OEN

$\mathrm{OvG}$

PHS

SOK

STOVIA

TbSZ

VOC
Nederlandsch Indische Artsen School (Netherlands Indigenous Doctors School)

Nederlands Tijdschrift voor Geneeskunde (Netherlands Review of Medicine)

Nederlandse Vereeniging voor Tropische Geneeskunde (Netherlands Association for Tropical Medicine)

Onderwijs, Eeredienst en Nijverheid (Education, Worship and Industry)

Officier van Gezondheid (Health Officer, military)

Public Health Service

Sumatra's Oostkust (East Coast of Sumatra)

School Tot Opleiding Van Inlandsche Artsen (Training School indigenous doctors)

Translated by Sjoerd Zondervan

Verenigde Oost-Indische Compagnie (Dutch East-India Company) 


\section{INDEX OF SUBJECTS}

\author{
Association 7, 15, 44, 69, 110, 124, 142, \\ $152,161,176,178,179,180,181,184$, \\ $186,213,214,216,285$ \\ Blind people 123, 181, 214, 215 \\ Boedi Oetomo 88 \\ Commercial Association HVA 169 \\ Deaconess Association 17, 44, 210 \\ Hospital Association 161 \\ ISDV Association 142 \\ Leprosy 122, 176, 178, 214 \\ Medical science 57, 62, 89 \\ Missionary associations 55, 176, 250, \\ Moehammadyah 171 \\ NMG Association 179 \\ Nursing Association NI 112, 171 \\ Plantation Association 90 \\ Tropical Medicine 91, 280, 291 \\ Tuberculosis 179, 180, 214, 215, 216, \\ 277
}

Beriberi 24, 30, 58, 66, 71, 75, 84, 89, 90 , $92,100,102,103,104,119,125,126$, $132,136,144,145,146,149,153,154$, 250, 252

Beriberi hospitals 71, 75, 79, 81, 95, 96, $97,125,126,128,130,132,145,175$, 237, 239, 241, 244, 247

Binnenlands Bestuur 52, 214, 283, 290

British India 19, 54, 72, 94, 95, 146, 148, 149, 192, 205, 206, 207, 220, 222, 223, $224,228,240,243,248,249,250,251$, 264, 274, 278

British Malay 207,

Buitenhospitaal (See Outer City Hospital)

Central Civil Hospital 67, 128, 150, 162, 164, 195, 196, 198, 199, 203, 205, 238, 245, 290

Charity hospitals 13, 64, 106, 112, 128, $150,156,159,161,171,175,201,210$, 244, 245, 256

Deaconess hospitals 106, 107, 108, 112, $132,150,152,156,166,171,172,208$, 209, 210

Missionary hospitals 55, 76, 87, 88, 92,
$96,99,106,112,114,116,132,150,152$, $154,156,160,171,172,173,185,190$, 203, 205, 208, 210, 211, 217, 226, 243, $245,247,250$

Chinese Hospital 18, 41, 43, 44, 70, 73, 79, $81,96,106,108,128,130,144,162,256$, 257

Cholera 57, 76, 92, 118, 127, 136, 146, 147, $149,153,154,185,195,201,240,250$,

252

Cholera boat 104

Cholera epidemic 240

Cholera hospital 76, 127

Cholera vaccine 146, 185, 193

Cholera ordinance 148, 193

City Dressing station 12, 38, 41, 66 - 68, $73,76,79,81,96,104,106-108,126$, $128,130,144,162,238,240,256,257$, 289

City Hospital 19, 31-36, 45- 47, 58, 59, 63, 65-67

Civil Medical Service 12, 16, 17, 19, 40, 54, $59,60,62,68,90-92,97,100,101,107$, $119,123,128-131,137,143-146,150$, $151,152,153,161,164,175,176,178$, 193, 199, 203, 205, 213, 236, 237, 239, 247, 249, 274, 276, 290

Medical Inspection 60, 110, 130

Head Office 22, 129

Civil Medical Division 138

Company Hospitals 69, 70, 76, 78, 81, 96, $97,99,106,116,117,128,132,144,154$. $156,161,166-169,171,185,186,190$, 203, 204, 210-212, 217, 226, 227, 238, 239, 241, 244, 246, 247

Plantations 116, 117, 167

Mining 117

Oil 117, 118

Other 118

Constitutional 137, 143

Convalescent hospitals 28, 43, 45, 46, 75, $76,79,81,95,97,124,125,132,176$, 179,180 
Council of the Indies 22, 39, 42, 52, 56, 72, 137

Cultuurstelsel 53, 56, 70, 84, 86, 87, 116

Deaconess Hospital (See Charity hospitals)

Decentralization 5, 17, 87, 88, 97, 137, $156,158,160,166,186,189,190,192$, 195, 197, 198, 215, 217, 227, 238, 247, Legislation 88, 97, 136, 207

Local Boards Ordinance 136

Dienst der Volksgezondheid (See Public Health Service)

Direct Rule 52, 53, 137

Dokter Djawa (see Medical Personnel)

Education 136, 141-143, 149, 150, 190-192, 194, 205, 207, 227, 237, 242, 249, 250, 251, 277, 289

Education \& Worship 120, 129, 137, $165,197,198,238,291$

Emancipation 19, 88,136, 142, 145, 190, 197, 227

Epidemics 14, 24, 58, 64, 92, 127, 133, 149,

153, 154, 236, 240, 249

Epidemic Ordinance 148

Epidemic Legislation 19, 148, 236

Malaria epidemic 58,

Smallpox epidemic 240

Cholera epidemic 240

Plague epidemic (See The Plague)

Ethical policy 17, 19, 85, 87, 93, 99, 106, $109,112,132,136,141,142,145,158$, $190,237,239,241,249,250,278$

Eye diseases 92, 95, 96, 119, 123, 124, 153, $169,176,180,202,213-215,251$

Doekoen mata 123, 159, 185, 288

Eye hospitals $119,123,124,175,180$, 181, 182, 185, 215, 266, 285

Eye clinic 123, 124, 174, 181, 182, 215, Cataract 123

Trachoma 100, 114, 123, 180, 181, 215

Faculty of Medicine 150, 196, 205, 225 , 245

Framboesia See Yaws

Geneeskundige Hogeschool (See Faculty of Medicine)
Governmental departments 54, 59, 60, 89, $110,112,120,129,137,138,146,165$, 191, 197, 198, 207, 224, 238, 266, 268

Government Civil Hospitals 88, 130,160$162,164,165,183,184,186,190,193$, 196, 198,199, 203,204, 208, 217 , $237,238,245,290$

Governor-general 22, 25, 26, 30, 32-34, $36-38,40,42,43,52,53,56,65,66,67$, $85,107,109,123,129,137,138,141$, $143,148,151,156,158,180,191,208$, 214, 216, 276, 288

Health Districts 91, 144, 159, 243, 247, 248

Health legislation $19,60,62,74,95,127$, $130,148,149,193,236,237$

Hygiene 24, 37, 62, 70, 77, 90, 147, 148, $149,169,175,193,194,212,215,224$, $250,268,273,277,283$

Indigenous Administration 52, 208

Indirect Rule 53, 137

Inlands Bestuur 52

Interior Administration 52

Indochina 19, 94, 95, 140, 148, 149, 205-207, 223, 248, 249, 250, 251

Institute Pasteur 89, 90, 129, 146, 147, 193, 204

Korte Verklaring 53, 85

Laboratory 58, 66, 89, 90, 91, 104, 116, $144,146,148,150,151,152,169,196$, 199, 203, 204, 238, 244, 245, 250, 252, 273, 277

Landskoepokinrichting (See Parc Vaccinogène)

Leprosy 15, 27, 28, 30, 31, 43, 44, 46, 70, $71,72,73,92,117,119-121,129,131$, $148,149,175-178,186,213-215,227$, $228,240,241,242,250,251,256,270$, 278

Leprosy association 122, 176, 178, 186, 214

Leprosy asylum 46, 47, 71, 72, 115, 120, 121, 177

Leprosy colony 175

Leprosy facility $72,121,137,174$

Leprosy hospital 28, 44, 71, 95, 97, 115, 
121, 132, 178, 244, 251, 256

Leprosy institution $71,72,79,81,98$, $110,115,117,119,120,121,174,176$, $177,190,214,259$

Leprosy legislation 149

Leprosy village 122,177

Malaria 23, 26, 33, 58, 66, 76, 77, 92, 96, $114,148,149,153,154,157,169,194$, 200, 201, 202, 244, 250, 252, 270, 282, 288

Malaysia 48, 78, 80, 95, 207, 223, 230, 232, 248

Malay States 207, 223, 224, 251

Medical personnel 32, 102, 150, 206, 236, 251

Civil physicians 132

Chirurgijns 22, 23, 25, 28, 32, 36, 37, 39, 40, 45, 47, 56, 59, 64, 268, 286

Dentists 60, 130, 151, 196, 245

Dokter Djawa 11, 57, 67, 88, 96, 98, $109,115,117,118,130,142,149,160$, 236, 243, 288

Laboratory personnel 151, 152, 196, 199, 203, 204, 244, 245

Mantri nurse 150, 152, 156, 159, 170, $171,182,185,186,196,200,205,215$, 244, 245, 289

Midwives 11, 56, 57, 69, 90, 129, 130, 133, 151, 196, 206, 207, 211, 245, 251, 274, 281, 288

Military doctors 98, 101, 105, 157, 158, 206, 236

Nurses 10, 32, 107, 110, 112, 113, 114, $133,149,151,152,156,171,174,180$, $181,182,185,200,201,202,205,206$, $207,212,215,217,225,226,244,245$, 280

Officers of health $56,57,58,62,89,91$, $98,100,101,105,115-117,123,129$, 144, 146, 157, 181, 236, 291

Pharmacists 151, 158, 193, 203, 204

Pharmacy assistants 151, 196, 203, 204, 205, 245

Vaccinators 56, 60, 61, 151, 193, 206, 245 ,
Military Hospital 11, 12, 16, 18, 36, 37, 38, 40, 58, 59, 64-68, 96, 98, 101-106, 128, $154,157-159,162,178,203,222,236$, 238, 239, 257, 263

Military Medical Service 12, 16, 60, 101, 104, 105, 131, 176, 203, 290

Military doctors (See medical personnel)

Military research 89, 104,

Missionary Hospitals (See Charity Hospitals)

Moorish Hospital 42, 46, 278

Municipal hospitals 156, 158, 160, 161, $162,165,166,183,186,190,195,198$, 199, 204, 216, 220, 225, 238, 241, 247,

Nurses (See Medical Personnel)

Ontvoogding (See Emancipation)

Ophthalmology 15, 30, 171, 201, 215, 282

Outer City Hospital 19, 34, 35, 36, 45, 46, 65, 66

Outpatient services 68, 90, 92-94, 97, 99, $100,101,107,108,113-116,119,123$, $124,131,132,136,141,143,149,150$, $157,158,159,161,168-171,180,181$, 183-186, 195, 198, 199, 205, 212, 223, $227,228,238,239,243,244,247,250$, 279, 283

Parc Vaccinogene 61, 89, 90, 129, 146, 147, 151, 204, 245

People's council 137, 141, 143, 150

Pharmacy 33, 39, 45, 60, 66, 103, 111, 130, 151, 195, 196, 199, 203-205, 210, 244, 245

Philippines 19, 48, 78, 80, 94, 95, 147, 148, $149,205-207,223,224,230,232,248$, 249-251, 268

Plague The 13, 29, 136, 145-149, 153, 154, $169,178,193,195,227,250,277$

Political organizations 142, 143, 171,181, $185,191,225$

Boedi Oetomo 142, 143, ISDV 142

Moehammadyah 142, 143, 171, 181, 185

NSB 225 
Partai Nasional Indonesia 143, 191

Sarekat Islam 142,

Wanita Oetomo 143

Provincial hospitals 158, 161, 165, 166, $167,215,217,247$

Psychiatry 15, 95, 118, 126, 132, 176, 182, 183, 197, 244, 279

Commission 126

Hospitals 78, 81, 95, 97, 98, 132, 213, 251, 263, 266

Nursing homes 213

Passage houses 213

Public Health Service 19, 131, 145, 151, $157,165,172,181,183,184,193-199$, 203, 204, 205, 208, 212, 214-217, 227, $238,245,266,267,275,284,290$

Public Hospitals 15-18, 69, 70, 95, 96, 106, 108, 130, 137, 156-158, 160-162, 165, 183, 186, 190, 195, 196-199, 203, 204, 208, 218, 226, 227, 238-240, 246-248, 263

Quarantine institutions 14, 31, 130, 148, 153, 195

Quinine 58, 76, 96, 100, 204, 242, Quinine Factory 58

Reorganization Commission 12, 97, 110, $129,130,131,143,144,159,160,162$, 175, 199, 248, 281

Rubber Fund 214, 215, 216

Salvarsan 96, 144, 145, 157, 170, 204, 209, 242, 272

Salvation Army 122, 124, 162, 171, 174, $175,177,178,182,210,241$

Schools

Nias 150, 196, 245, 291

Stovia $88,98,103,104,142,149,150$, $163,180,196,291$

Skin diseases 72, 92, 100, 153, 200-202, 256

Smallpox 59, 60, 61, 73, 76, 89, 92, 121, $127,146,148,149,153,154,185,193$, 201, 240, 243, 250, 269

Snake bites 92, 146

Spanish Flu 136, 153, 155

Specialized hospitals 30, 43, 64, 70, 71, 95,
$97-99,118,119,128,130,132,174,175$, $190,211,213,214,217,218,222,228$, 237, 239, 240, 247, 251, 263

Stadsverband (See City Dressing Station) Subsidy regulations 55, 76, 88, 97, 109, $110,113,115,121,122,124,145,158$, $160,164,165,166,168,171,172-174$, $178,199,209,237,247$,

Sugar industry $42,53,116,117,124,138$, $140,167,168-170,192,210-213,228$, $239,241,277,283$,

Syphilis 73, 96, 118, 119, 121, 132, 144, $153,175,201,249$ Hospitals 73, 78, 80, 95, 97, 128, 130, $144,145,161,164,165,175,237,240$, 244 ,

Traditional medicine 10, 14, 17, 57, 90, $100,242,251,252$

Doekoen 14, 56, 60, 130, 207, 242, 286, 288

Doekoen baji 56, 207, 288

Doekoen mata 123, 159, 185, 288

Dhais 207

Ba Mu 206

Tropical Medicine 19, 44, 57, 84, 90, 91, 145-147, 194, 212, 268, 275, 276, 280

Tuberculosis 121, 153, 176, 178, 179, 180, $186,194,195,200,201,202,204,216$, 217, 227, 247, 251, 276, 277

Sanatorium 31, 178, 180, 181, 215, 216, 217, 238, 239

TB prevention clinics 180

Typhoid fever 127, 148, 149, 154, 185

Vaccination $60,61,76,144,149,159,236$, 240, 247, 269

Cholera 194

Circles 61, 228

Districts 138, 193

Service 14, 59, 61

Smallpox 59, 60, 73, 76, 89, 149,185, 240, 243

Parc Vaccinogene 61, 89, 90, 129, 146, 147, 151, 204, 245

Regulations 59

Training 61, 151, 194 
INDEX OF SUBJECTS

VOC hospitals 27, 28, 29, 64, 236

Volksraad (See People's Council)

Welvaartsdiensten 191

X-ray 201, 203, 204, 216, 217

Yaws 84,92 , 96, 100, 114, 136, 144, 157, 169,170 